\title{
HYDROLOGIC AND SEDIMENTOLOGIC DATA COLLECTED DURING THREE CRUISES AT LOW WATER ON THE MISSISSIPPI RIVER AND SOME OF ITS TRIBUTARIES, JULY 1987- JUNE 1988
}

by John A. Moody and Robert H. Meade

U.S. GEOLOGICAL SURVEY

Open-File Report 91-485 


\section{U.S. DEPARTMENT OF THE INTERIOR}

\section{MANUEL LUJAN, JR., Secretary}

\section{U.S. GEOLOGICAL SURVEY}

Dallas L. Peck, Director

For additional information write to:

Chief, Branch of Regional Research U.S. Geological Survey Box 25046, Mail Stop 418 Denver Federal Center Denver, CO 80225-0046
Copies of this report can be purchased from:

U.S. Geological Survey Books and Open-File Reports Section Box 25425, Mail Stop 517 Federal Center Denver, CO 80225-0425 
Abstract-0-

Introduction--

Acknowledgments--

Objectives of project--

Purpose and scope-10

Bed sediments-0.

Water-discharge measurement-

Suspended sediment-

Suspended-sediment size analysis-0.

Size analysis of suspended sands-

Size analysis of suspended silt and clay-

Surface-water properties-

Dewatering of samples-co

July-August 1987 cruise--o

November-December 1987 cruise-1

May-June 1988 cruise--

Near bottom current measurements

Surface-water travel-time measurements--

References cited-

Tabulated cruise data-0

July-August 1987 cruise-

November-December 1987 cruise-

May-June 1987 cruise--

Page

\section{FIGURES}

Figure 1. Map of Mississippi River drainage basins-_.

2. Map of Mississippi River and some tributaries and

location of sampling cross sections- 6

3-6. Daily water discharge at selected sampling sections from July 1, 1987 to June 30, 1988

3a. Mississippi River near Winfield, Mo.-- 7

3b. Illinois River at Meredosia, I11._. 7

3c. Missouri River at Hermann, Mo..- 7

3d. Mississippi River at St. Louis, Mo._... 7

4a. Mississippi River at Thebes, I11._.-. 8

4b. Ohio River at Metropolis, I11... 8

4c. Mississippi River at Hickman, Ky.-. 8

5a. Mississippi River at Helena, Ark.-. 9

5b. White River at $\mathrm{Clarendon,} \mathrm{Ark.-19} 9$

5c. Mississippi River at Arkansas City, Ark._-_..-- 9

6a. Mississippi River at Vicksburg, Miss.-_-_..... 10

6b. Old River Outflow Channel near Knox Landing, La.--- 10

6c. Mississippi River at Tarbert Landing, La.--..- 10

7. Suspended-sediment sampler with current meter-a-16

8. Graph showing the correlation between the vertical transit rate and the ratio of the final discharge to the average down- and upcast discharge--- 
Figure 9. Graph showing the comparison of the concentration of

Page

the silt and clay fraction and the concentration of

the sand fraction in composite $A$ and composite $B$ for

the three cruises--

10. Flow diagram for the processing stages of the

suspended-sediment samples-- 36

11-23. Graphs showing depth, velocity, and discharge versus

the distance from the left bank for July-August

1987 cruise

11. Mississippi River at Hartford, I11._. 47

12. Missouri River at Hermann, Mo.- 49

13. Mississippi River at St. Louis, Mo._. 51

14. Mississippi River at Chester, Ill._._. 53

15. Ohio River at 0lmsted, Ill. 55

16. Mississippi River below Hickman, Ky. 57

17. Mississippi River at Helena, Ark. 59

18. White River at Mile 11.5, Ark. 61

19. Arkansas River at Mile 55.9, Ark. 64

20. Mississippi River above Arkansas City, Ark._-_...- 66

21. Mississippi River below Vicksburg, Miss.-...-..- 68

22. Old River Outflow Channel near Knox Landing, La.--- 70

23. Mississippi River near St. Francisville, La.--.-- 72

Figures 24-38. Graphs showing depth, velocity, and surface

conductivity versus the distance from the left bank

for the November-December 1987 cruise:

24. Mississippi River near Winfield, Mo.-_ 75

25. Missouri River at St. Charles, Mo._- 77

26. Mississippi River at St. Louis, Mo._. 79

27. Mississippi River at Thebes, I11._. 81

28. Ohio River at 0lmsted, IIl._. 83

29. Mississippi River below Hickman, Ky._. 85

30. Mississippi River at Fulton, Tenn._... 87

31. Mississippi River at Helena, Ark._. 90

32. White River at Mile 11.5, Ark._- 92

33. Mississippi River above Arkansas City, Ark._-_._-_ 95

34. Yazoo River at Mile 10, Miss..- 97

35. Mississippi River below Vicksburg, Miss.-_-_-_- 100

36. 0ld River Outflow Channel near Knox Landing, La.--- 102

37. Mississippi River near St. Francisville, La.-_-_--- 104

38. Mississippi River below Belle Chasse, La.-_-_-_-- 106

Figures 39-53. Graphs showing depth, velocity, and surface

conductivity versus the distance from the left bank

for the May-June 1988 cruise:

39. Mississippi River near Winfield, Mo._- 109

40. Illinois River below Meredosia, I11.---_- 111

41. Missouri River at Hermann, Mo.--_e 114

42. Mississippi River at St. Louis, Mo.-- 116

43. Mississippi River at Thebes, I11._-_.-. 119

44. Ohio River at 01msted, Il1.-_ 121

45. Mississippi River below Hickman, Ky.---_- 124

46. Mississippi River at Fulton, Tenn.-- 126

47. Mississippi River at Helena, Ark.... 129 
Figures 39-53. Graphs showing depth, velocity, and surface

Page conductivity versus the distance from the left bank for the May-June 1988 cruise:--Continued

48. White River at Mile 11.5, Ark._. 131

49. Mississippi River above Arkansas City, Ark._.....- 133

50. Mississippi River below Vicksburg, Miss........ 137

51. 01d River Outflow Channel near Knox Landing, La.---- 139

52. Mississippi River near St. Francisville, La...... 141

53. Mississippi River below Belle Chasse, La........- 143

\section{TABLES}

Table 1. Drainage-basin areas, and mean annual discharges of water and sediment for each basin-. 3

2. Cross-section sampling locations during cruises of July-August 1987, November-December 1987, and May-June 1988-

3-5. Particle size, determined by sieving, of sediment collected from the beds of the Mississippi River and its principal tributaries:

3. July-August 1987 cruise-12

4. November-December 1987 cruise--_e 13

5. May-June 1988 cruise-_o 14

6-8. Statistics of the vertical depth-integration method which was used to collect suspended sediment:

6. July-August 1987 cruise-_- 17

7. November-December 1987 cruise-_-_ 18

8. May-June 1988 cruise-- 18

9-11. Summary of discharge measurements made using the depth-integration method:

9. July-August 1987 cruise--n 20

10. November-December 1987 cruise-_-_.- 21

11. May-June 1988 cruise-- 22

12-14. Concentrations of suspended sediment in composite depth-integrated samples collected in the Mississippi

River and its principal tributaries and the corresponding sediment discharge:

12. July-August 1987 cruise-15

13. November-December 1987 cruise--_- 26

14. May-June 1988 cruise--_ 27

15-17. Particle size, determined by Sedigraph and visua1accumulation tube of composite suspended sediment collected from the Mississippi River and its principal tributaries:

15. July-August 1987 cruise-1

16. November-December 1987 cruise--_ 32

17. May-June 1988 cruise-- 33

18. Comparisons of particle-size analyses of sand fractions $(>63 \mu \mathrm{m})$ of composites A and B from selected samples---- 34 
Tables 19-21. Water volume processed and mass of silt and colloidal

material recovered from samples of the Mississippi

River and its principal tributaries:

19. July-August 1987 cruise-n 37

20. November-December 1987 cruise-_a 38

21. May-June 1988 cruise-- 39

22. Deployment locations of a moored vector averaging current meter in the Mississippi River and its principal tributaries- 40

Table 23. Statistics of drift cards released in the Mississippi

River and its principal tributaries-a 41

24. Surface-water travel time for river reaches between cross-section sampling sites on the Mississippi River and its principal tributaries.

CONVERSION FACTORS

Multiply

micrometer $(\mu \mathrm{m})$

millimeter $(\mathrm{mm})$

meter (m)

kilometer $(\mathrm{km})$

square meter $\left(\mathrm{m}^{2}\right)$

square kilometer $\left(\mathrm{km}^{2}\right)$

$\begin{array}{ll}\text { milliliter } & (\mathrm{mL}) \\ \text { liter } & (\mathrm{I}) \\ \text { cubic meter } & \left(\mathrm{m}^{3}\right)\end{array}$

centimeter per second $(\mathrm{cm} / \mathrm{s})$

meter per second $(\mathrm{m} / \mathrm{s})$

cubic meter per second $\left(\mathrm{m}^{3} / \mathrm{s}\right)$

cubic meter per year $\left(\mathrm{m}^{3} / \mathrm{y}\right)$

kilometer per hour $(\mathrm{km} / \mathrm{h})$

liter per minute ( $\mathrm{L} / \mathrm{min}$ )

milligram (mg)

gram (g)

metric ton

degree Celsius $\left({ }^{\circ} \mathrm{C}\right)$
$\underline{B y}$

Length

0.00003937

0.03937

3.281

0.6214

Area

10.76

0.3861

Volume

0.03382

0.2642

35.31

Flow

0.03281

3.281

35.31

35.31

0.6214

0.2642

Mass

0.00003527

0.002205

2,205

Temperature

$\mathrm{F}=1.8 \times{ }^{\circ} \mathrm{C}+32$

\section{To obtain}

inch

inch

foot

mile

square foot

square mile

ounces, fluid

gallon

cubic foot

foot per second

foot per second

cubic foot per second

cubic foot per year

mile per hour

gallon per minute

ounce, avoirdupois

pound, avoirdupois

pound, avoirdupois

degree Fahrenheit 
HYDROLOGIC AND SEDIMENTOLOGIC DATA COLLECTED DURING THREE CRUISES AT LOW WATER ON THE MISSISSIPPI RIVER AND SOME OF ITS

TRIBUTARIES, JULY 1987-JUNE 1988

By John A. Moody and Robert H. Meade

\begin{abstract}
Water, suspended-sediment, and bed-sediment samples were collected for physical (particle size and mineralogy) and chemical analysis (radioactive elements, trace metals, nutrients, petrochemical hydrocarbons, organic volatiles, pesticides, detergents, organic carbon, and humic substances) from 21 sites on the Mississippi River and its main tributaries. Three cruises were made at low water during a 1-year period from July 18, 1987, to June 7 , 1988. The maximum measured discharge was about 10,400 cubic meters per second on December 15, 1987, at Vicksburg, Mississippi, and the maximum measured suspended-sediment discharge was 354,000 metric tons per day in the Missouri River at Hermann, Missouri, on July 20, 1987. The equal-width-increment (equal-transit-rate), depth-integration method was used at 10-40 verticals across the river to collect between 70 and 137 liters of river water with an isokinetic sampler (made of Teflon to prevent chemical contamination).

This report contains the following hydrologic data associated with the suspended-sediment samples: cross-sectional area of the river; mean depth; mean velocity; water discharge; particle sizes; concentrations of the suspended sand, silt, and colloid fractions; and surface temperature and conductivity at 10-40 locations across the river. These data provide the framework for subsequent interpretive chemical analyses of the samples collected during the three cruises.
\end{abstract}

\title{
INTRODUCTION
}

The Mississippi River drains about 40 percent of the conterminous United States. At Vicksburg, Mississippi, it has a mean annual water discharge of about $500 \times 10^{9} \mathrm{~m}^{3} / \mathrm{y}$ and a sediment load of about $200 \times 10^{6} \mathrm{metric}$ tons $/ \mathrm{y}$. At 120 river miles below Vicksburg, approximately 25 percent of the water discharge and sediment discharge is diverted from the Mississippi River into the Atchafalaya River by the 0ld River Control Structures. The remaining water $\left(375 \times 10^{9} \mathrm{~m}^{3} / \mathrm{y}\right)$ and sediment $\left(150 \times 10^{6}\right.$ metric tons/y) are discharged by the Mississippi River directly into the Gulf of Mexico.

On the basis of distinctive differences in water chemistries, the Mississippi River basin has been divided into eight subbasins shown in figure 1 and listed in table 1 with their corresponding drainage areas, and the mean annual discharges of water and sediment. 


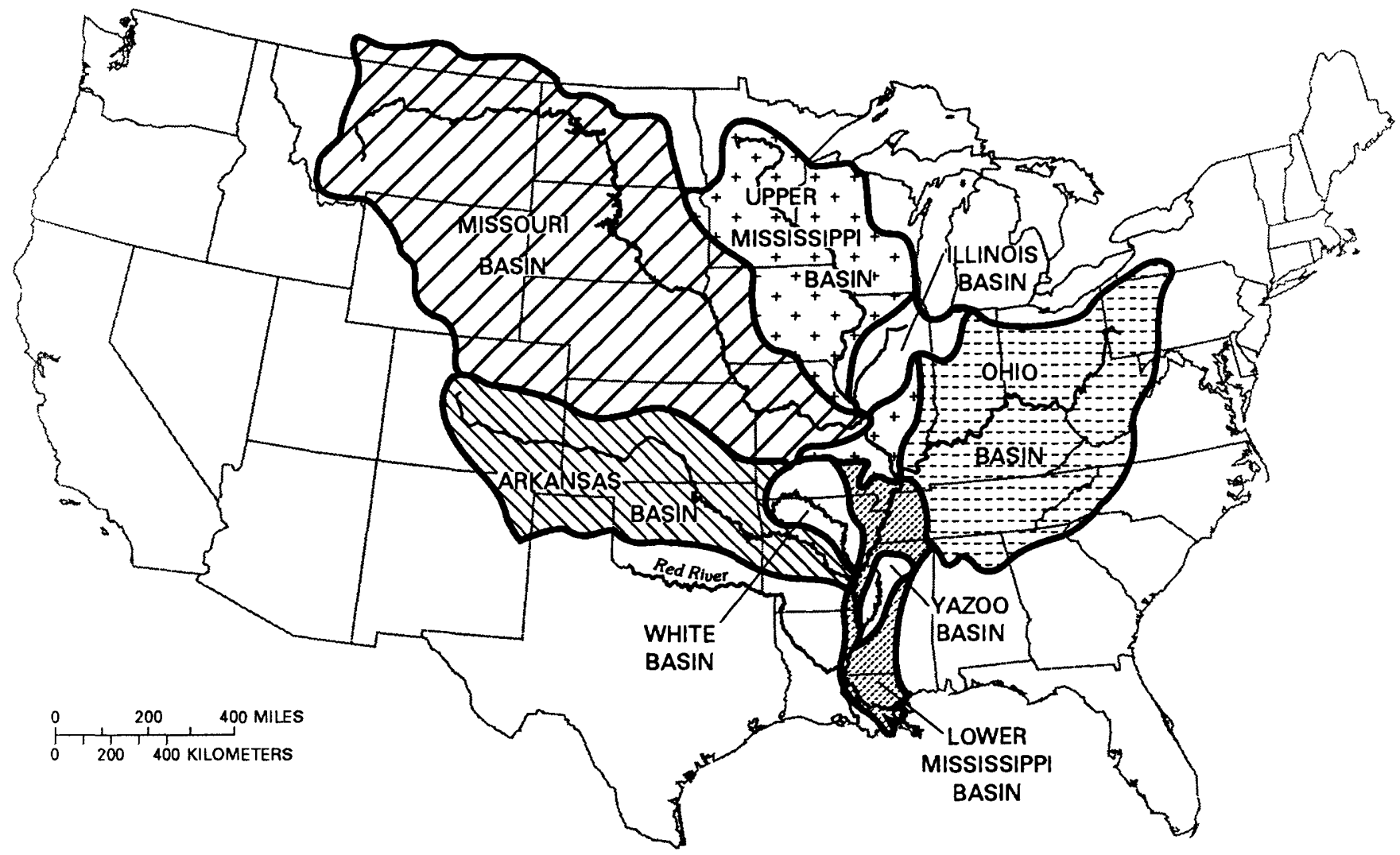

Figure 1.--Mississippi River drainage basin, which comprises eight subbasins. The Red River basin was not included because it is no longer a tributary to the Mississippi River. Adapted from Bragg (1977).

\section{Acknowledgments}

The U.S. Army Corps of Engineers representatives from the following districts provided extremely helpful and friendly assistance during and after the cruises: Samuel Lehr and Dorothy Wilson, Memphis District; Billy Garrett and John Miller, New Orleans District; Claude Strauser, Robert Barkau, and Shirley Bledsoe, St. Louis District; Henry Noble, Thomas Runnels and Wesley Bird, Vicksburg District; and James Farrel with the Lower Mississippi Valley Division. 
Table 1.--Drainage-basin areas and wean annual discharges of water and sediment for each basin

[The basin areas and sediment discharges are taken from Keown and others (1981) except where noted. Values of the water discharges were taken from the U.S. Geological Survey water-resources data reports for the appropriate States, except where noted]

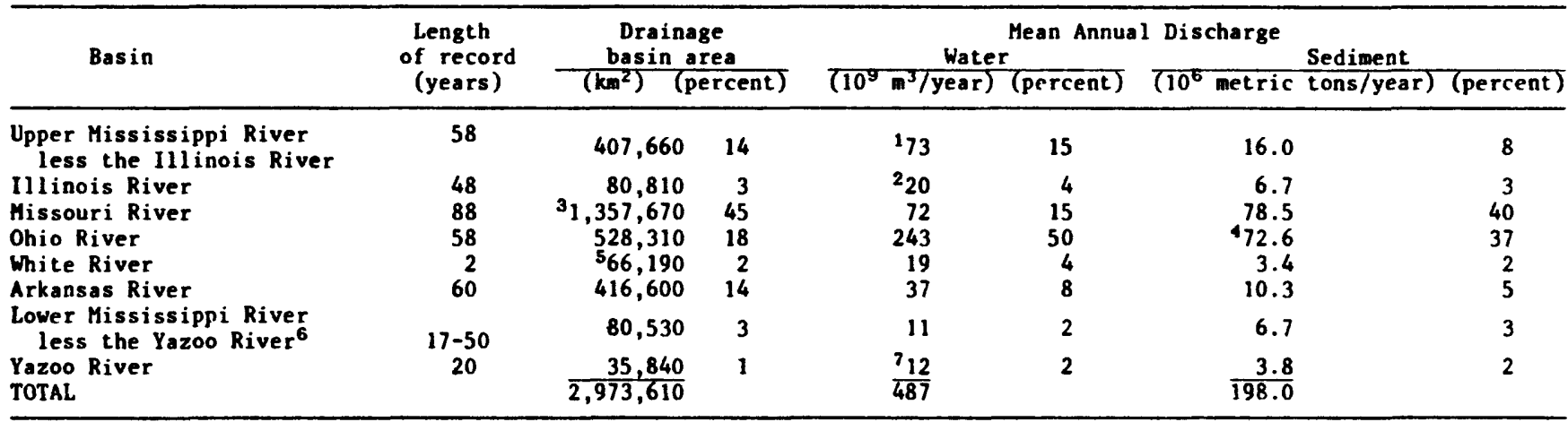

\footnotetext{
'Discharge for Mississippi River at Alton, Illinois minus discharge for the Illinois River.

${ }^{2}$ Discharge for the Illinois River below Meredosia, Illinois.

${ }^{3}$ Drainage area taken from the Missouri Water Resources Data for water years 1985-86.

'Sediment discharge was estimated by Keown and others (1981) by differences.

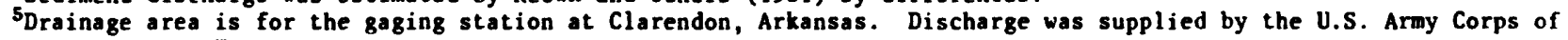
Engineers, Memphis, Tennessee.

6Seven tributaries: St. Francis, Obion, Hatchie, Wolf, Big Black, Homochitto, and Buffalo Rivers.

${ }^{7}$ Combined discharges (1967-87?) for the Yazoo River at Greenwood, Mississippi, and the Big Sunflower River at Sunflower, Mississippi (Henry Noble, U.S. Army Corps of Engineers, oral commun., 1988).
}

Many people along the river provided permission for docking, loading, and repairing the ship and equipment, and they often went out of their way to be helpful: Renee Ory and people at Ory Brothers Marine Service of America in Hartford, Illinois; Rusty Sutton in Grafton, Illinois; Pablo Lara, Ron Brant, and people at the Central Illinois Power Company in Meredosia, Illinois; Daniel Gipe and people at Hermann Sand and Gravel Company in Hermann, Missouri; Captain William Carroll and the people at Gateway River Cruises in St. Louis, Missouri; Kent Hoffmeister and the workers at Missouri Dry Dock and Repair Company in Cape Girardeau, Missouri; the crew at Lock and Dam 53 near Olmsted, Illinois; the U.S. Coast Guard Station in Hickman, Kentucky; John Janoush and the people at Janoush Marine, Inc., in Rosedale, Mississippi; the crew at Norrell Lock 非 1 near Arkansas Post, Arkansas; Mary Hosemann and the people working on the Spirit of Vicksburg in Vicksburg, Mississippi; and the people running the New Roads Ferry at St. Francisville, Louisiana, and the Belle Chasse Ferry at Belle Chasse, Louisiana.

Paul Hayes helped us on the Illinois River; Leon Reed and Larry Lumpkin helped us on the Missouri River at Hermann; Dale Hatten, George Gray, Leonard Huber, and Roger Nygaard have gone out of their way repeatedly to cooperate with us in making simultaneous measurements of the Mississippi River at St. Louis; Jack Doyle was helpful with measurements of the Ohio River; Harry Doyle made an extra effort to see that some specialized equipment was delivered to the ship in Memphis, Tennessee; Terry Lamb provided special and practical information on the Arkansas River; Harold Bishop, Fred Morris, Paul Grantham and Destry Phillips have altered their schedules to assist on sampling the sluggish but chemically interesting Yazoo River and the wide and deep Mississippi River at Vicksburg, Mississippi; and Charles Demas and Nolan Couvillion have been valuable sources of practical and technical assistance in sampling and measuring the Mississippi River at St. Francisville and Belle Chasse, Louisiana. Bill Matthes, Carol Anderson, and Mike Werito completed all the particle-size analyses. C. Clare Cranston constructed and installed some of the sampling equipment and taught us how to use it. 
The crew of the R/V ACADIANA--Lee Black, Wayne Simoneaux, Chuck Guidry, Steve Rabalais, Ken 0livier, and Wilton Delaune--have been especially accommodating and have shown an unusual interest and concern in maintaining proper scientific operations.

Measuring river discharge or collecting suspended-sediment samples from large rivers is not a two-man operation and the following people's collaboration was necessary to get the job done: Terry Brinton, Pat Brown, John Garbarino, Tom Leiker, Jerry Leenheer, Brent McKee, Ted Noyes, Wilfred Pereira, Jim Ranville, Terry Rees, Colleen Rostad, Bob Stallard, Herb Stevens, Howard Taylor, and Tim Willoughby.

\section{Objectives of Project}

The broad objectives of this multidisciplinary project are to investigate the movement, mixing, and storage processes of sediment-associated pollutants in the Mississippi River system. Some specific objectives are to:

1. Understand the compartmentalization of synthetic organic agrochemicals between the water, sediment, and biotic phases.

2. Investigate the processes of mixing, partitioning, and redistribution of the various pollutants below major river confluences.

3. Understand the movement, storage, and remobilization of suspended sediment and associated pollutants at seasonal or longer time scales.

4. Predict the location and travel time of water masses and the associated sediment and pollutants.

5. Examine the geochemistry of the colloidal and dissolved phases of river water.

\section{Purpose and Scope}

The purpose of this report is to provide a description of the sampling sites on the Mississippi River and its principal tributaries and a description of the sampling procedures used to collect water and suspended-sediment samples for physical and chemical analysis. The basic hydrologic data associated with these samples are the water depth, river discharge, surface temperature and conductivity, concentration of suspended sand $(>63 \mu \mathrm{m})$, silt/clay and colloidal material $(<63 \mu \mathrm{m})$ in suspension, and the size distribution of the suspended and bed sediments. Chemical data are published elsewhere. The hydrologic data that are published in this report provide some of the necessary framework for interpreting the chemical data.

The 17-m research vessel ACADIANA, owned and operated by the Louisiana Universities' Marine Consortium, was used for collecting the samples because it has a shallow draft (about $1.2 \mathrm{~m}$ ), permitting samples to be collected close to the river banks. Each cruise started upriver from St. Louis, Missouri, and samples were collected in a Lagrangian scheme that tried to follow the same water mass downriver. This sampling scheme was limited by the logistical constraints of using a single ship to sample the tributaries and the mainstem Mississippi River, and by the time available to process samples. This report includes data from three cruises; the first cruise was from July 18 to August 9, 1987; the second cruise was from November 29 to December 20, 1987; and the third cruise was from May 16 to June 7, 1988. Seventeen sites or sections (see table 2 and fig. 2) were sampled during the first cruise, and sixteen sections during the second and third cruises. 
The cruises were planned to collect samples at different stages of the annual flow hydrograph; but, because of drought conditions during spring 1988 (when normal high stages occur), all three cruises occurred during low discharge (see figs. 3, 4, 5, and 6).

Table 2.--Cross-section sampling locations during cruises of July-August 1987, November-December 1987, and May-June 1988

[The $\mathrm{X}$ designates that the cross section was sampled]

\begin{tabular}{|c|c|c|c|c|}
\hline Section name & River mile ${ }^{1}$ & $\begin{array}{c}\text { July- } \\
\text { August } \\
1987 \\
\end{array}$ & $\begin{array}{c}\text { Cruise } \\
\text { November- } \\
\text { December } \\
1987 \\
\end{array}$ & $\begin{array}{l}\text { May- } \\
\text { June } \\
1988 \\
\end{array}$ \\
\hline $\begin{array}{l}\text { Mississippi River near Winfield, Mo. } \\
\text { Illinois River below Meredosia, Ill. } \\
\text { Mississippi River at Hartford, Ill. } \\
\text { Missouri River at Hermann, Mo. } \\
\text { Missouri River at St. Charles, Mo. } \\
\text { Mississippi River at St. Louis, Mo. } \\
\text { Mississippi River at Chester, Ill. }\end{array}$ & $\begin{array}{lr}\text { UM } & 239.2 \\
\text { IL } & 67.2 \\
\text { UM } & 197.7 \\
\text { MO } & 97.9 \\
\text { MO } & 28.1 \\
\text { UM } & 179.3 \\
\text { UM } & 108.9\end{array}$ & $\begin{array}{l}x \\
X \\
x \\
x \\
X \\
X\end{array}$ & $\begin{array}{l}X \\
X\end{array}$ & $\begin{array}{l}X \\
X \\
X \\
X\end{array}$ \\
\hline $\begin{array}{l}\text { Mississippi River at Thebes, Ill. } \\
\text { Ohio River below Smithland Locks and Dam, Ill.-Ky. } \\
\text { Ohio River at Olmsted, Ill. } \\
\text { Mississippi River below Hickman, Ky. } \\
\text { Mississippi River at Fulton, Tenn. } \\
\text { Mississippi River at Helena, Ark. } \\
\text { White River at Mile 11.5, Ark. }\end{array}$ & $\begin{array}{lr}\text { UM } & 43.9 \\
\text { OH } & 919.2 \\
\text { OH } & 965.0 \\
\text { LM } & 916.8 \\
\text { LM } & 777.3 \\
\text { LM } & 663.9 \\
\text { WH } & 11.5\end{array}$ & $\begin{array}{l}X \\
X \\
X \\
X \\
X \\
X\end{array}$ & $\begin{array}{l}X \\
X \\
X \\
X \\
X \\
X\end{array}$ & $\begin{array}{l}X \\
X \\
X \\
X \\
X\end{array}$ \\
\hline $\begin{array}{l}\text { Arkansas River at Mile } 55.9 \text {, Ark. } \\
\text { Mississippi River above Arkansas City, Ark. } \\
\text { Yazoo River at Mile 10, Miss. } \\
\text { Mississippi River below Vicksburg, Miss. } \\
\text { old River Outflow Channel near Knox Landing, La. } \\
\text { Mississippi River near St. Francisville, La. } \\
\text { Mississippi River below Belle Chasse, La. }\end{array}$ & $\begin{array}{lr}\text { AR } & 55.9 \\
\text { LM } & 566.0 \\
\text { YZ } & 10.0 \\
\text { LM } & 433.4 \\
& -- \\
\text { LM } & 266.4 \\
\text { LM } & 73.1\end{array}$ & $\begin{array}{l}X \\
X \\
X \\
X\end{array}$ & $\begin{array}{l}X \\
X \\
X \\
X \\
X \\
X\end{array}$ & $\begin{array}{l}X \\
X \\
X \\
X \\
X \\
X\end{array}$ \\
\hline
\end{tabular}

${ }^{1}$ UM, Upper Mississippi River miles measured upriver of confluence with Ohio River.

IL, Illinois River miles measured upriver of confluence with Mississippi River (UM 218.0).

MO, Missouri River miles measured upriver of confluence with Mississippi River (UM 195.3).

$\mathrm{OH}$, Ohio River miles measured downriver of Pittsburgh, Pa. Ohio-Mississippi River

confluence is at Ohio River Mile 981.5 and Lower Mississippi River Mile 953.8.

LM, Lower Mississippi River miles measured upriver of Head of Passes, La.

WH, White River miles measured upriver of confluence with Mississippi River (LM 598.8).

$A R$, Arkansas River miles measured upriver of confluence with Mississippi River (LM 581.5).

YZ, Yazoo River miles measured upriver of confluence with Mississippi River (LM 437.2). 


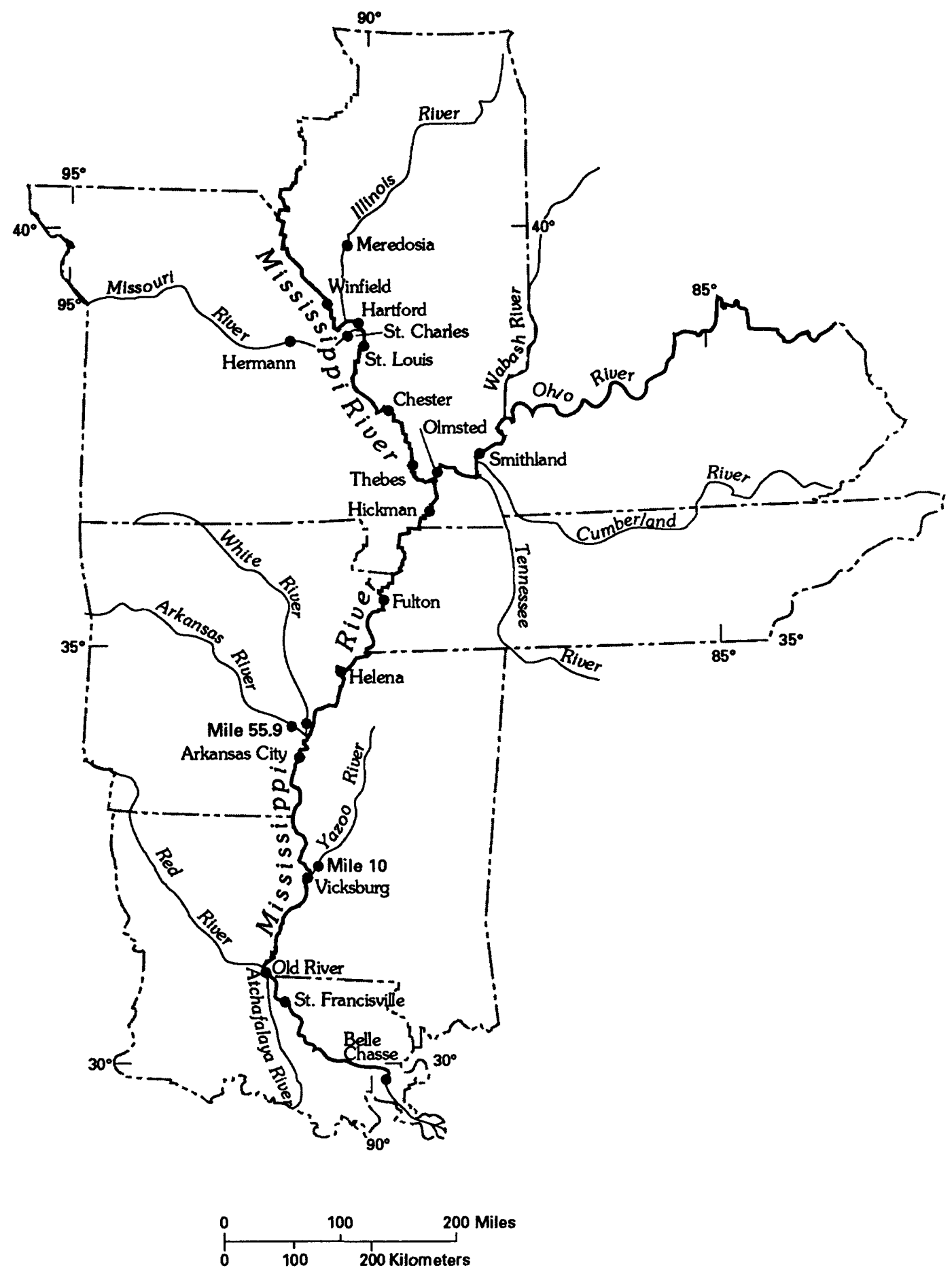

Figure 2.--Mississippi River and some tributaries. Sampling cross sections are shown as dots. See table 2 for more detailed information on location. 


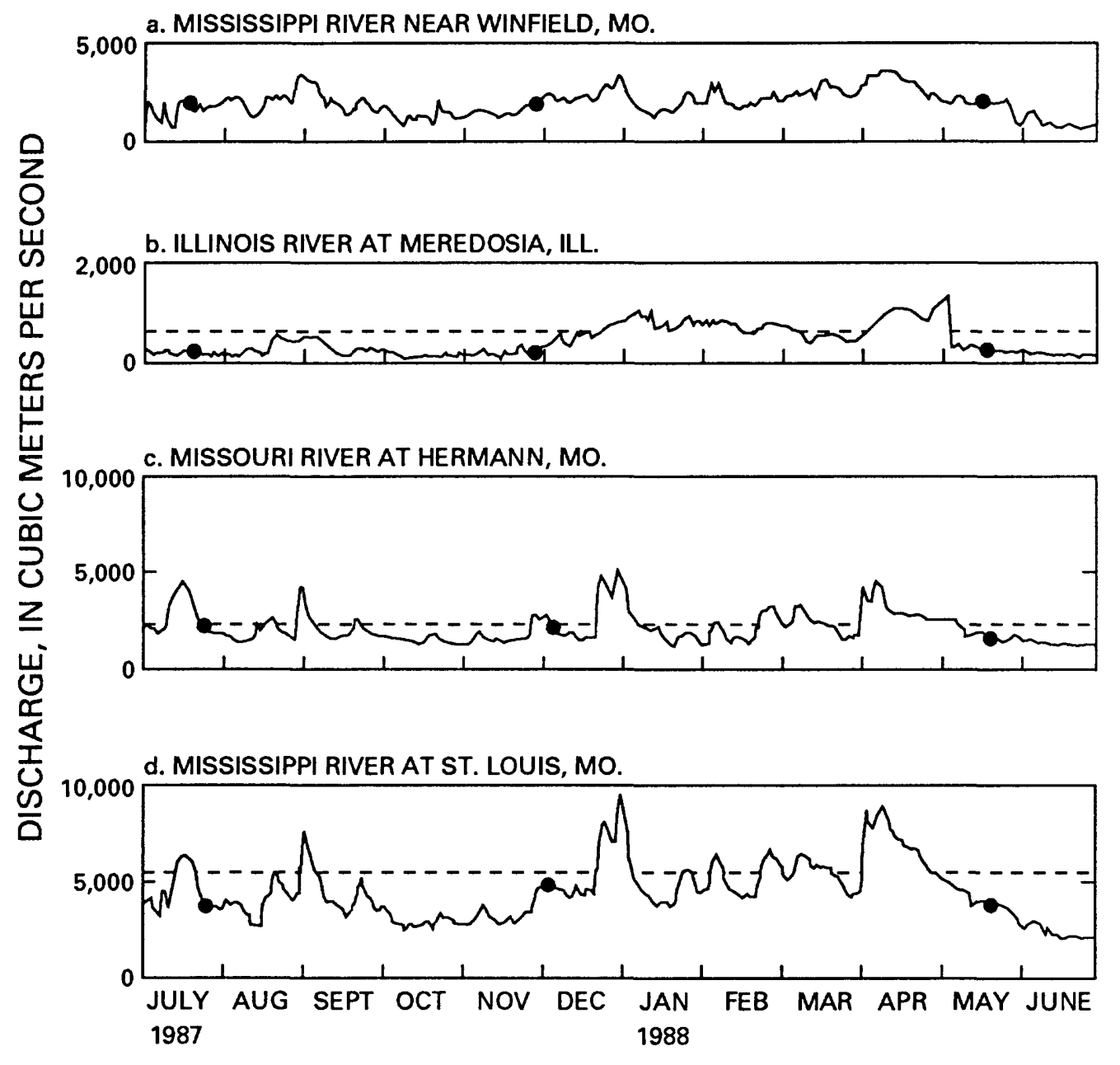

Figure 3.--Value of daily water discharges at selected sampling sections from July 1, 1987, to June 31,1988 . The day each section was measured (see tables 9, 10, and 11 for measured discharges) is shown as a solid dot. Dashed line is the mean discharge based on at least 49 years of record. Based on discharge data of the U.S. Geological Survey, except for the Mississippi River at Dam 22 (U.S. Army Corps of Engineers, Rock Island District).

a. Mississippi River near Winfield, Mo., is shown as the total of the Mississippi River at Dam 22 plus the Salt River at New London, Mo.

b. Illinois River at Meredosia, I11.

c. Missouri River at Hermann, Mo.

d. Mississippi River at St. Louis, Mo. 


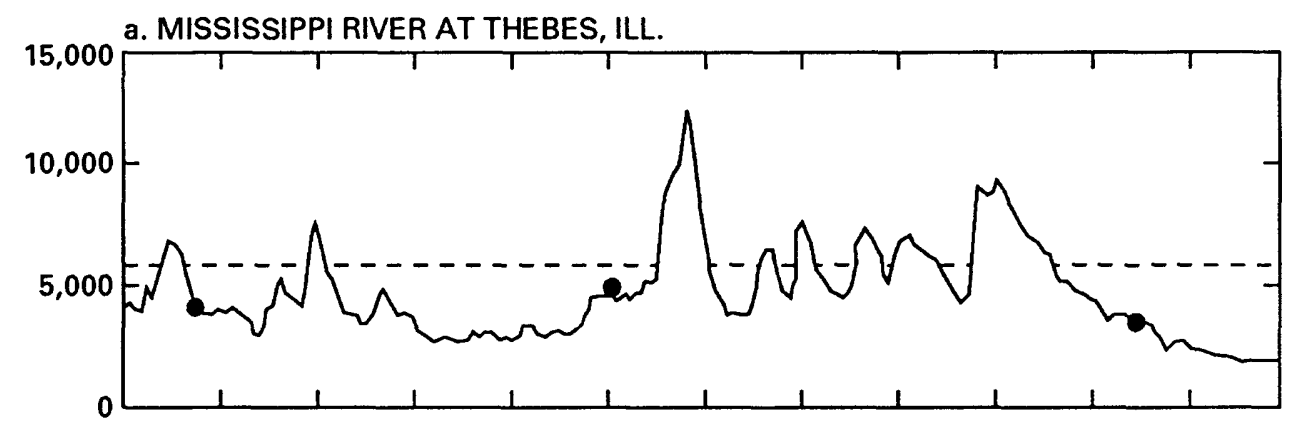

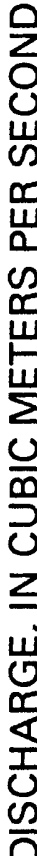

20,000 b. OHIO RIVER AT METROPOLIS, ILL.

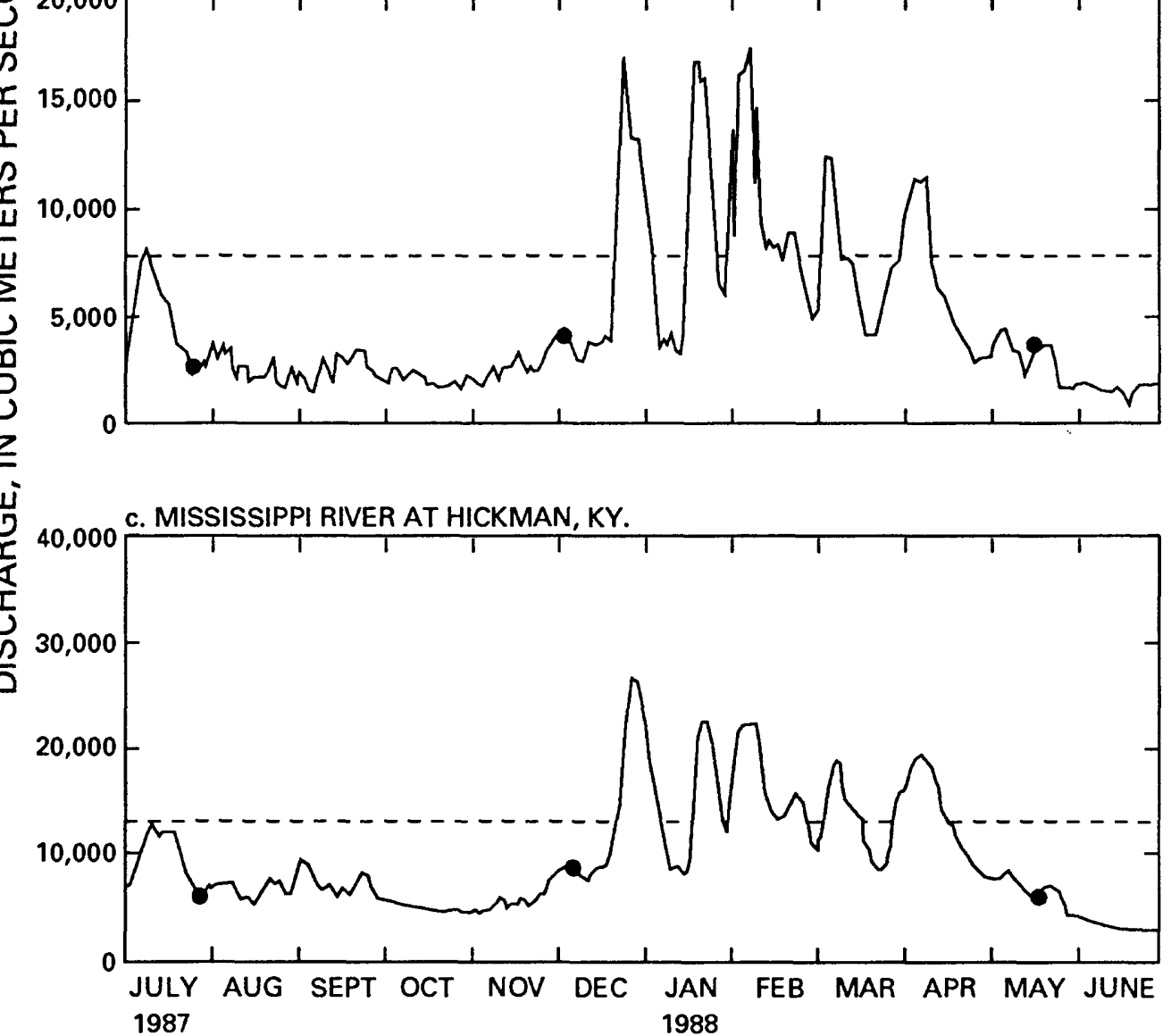

Figure 4.--Value of daily water discharges at selected sampling sections from July 1, 1987, to June 31,1988 . The day each section was measured (see tables 9, 10, and 11 for measured discharges) is shown as a solid dot. Dashed line is the mean discharge based on at least 49 years of record. Based on discharge data of the U.S. Geological Survey, except for the Mississippi River at Hickman (U.S. Army Corps of Engineers, Memphis District).

a. Mississippi River at Thebes, Ill.

b. Ohio River at Metropolis, I1l.

c. Mississippi River at Hickman, Ky. 


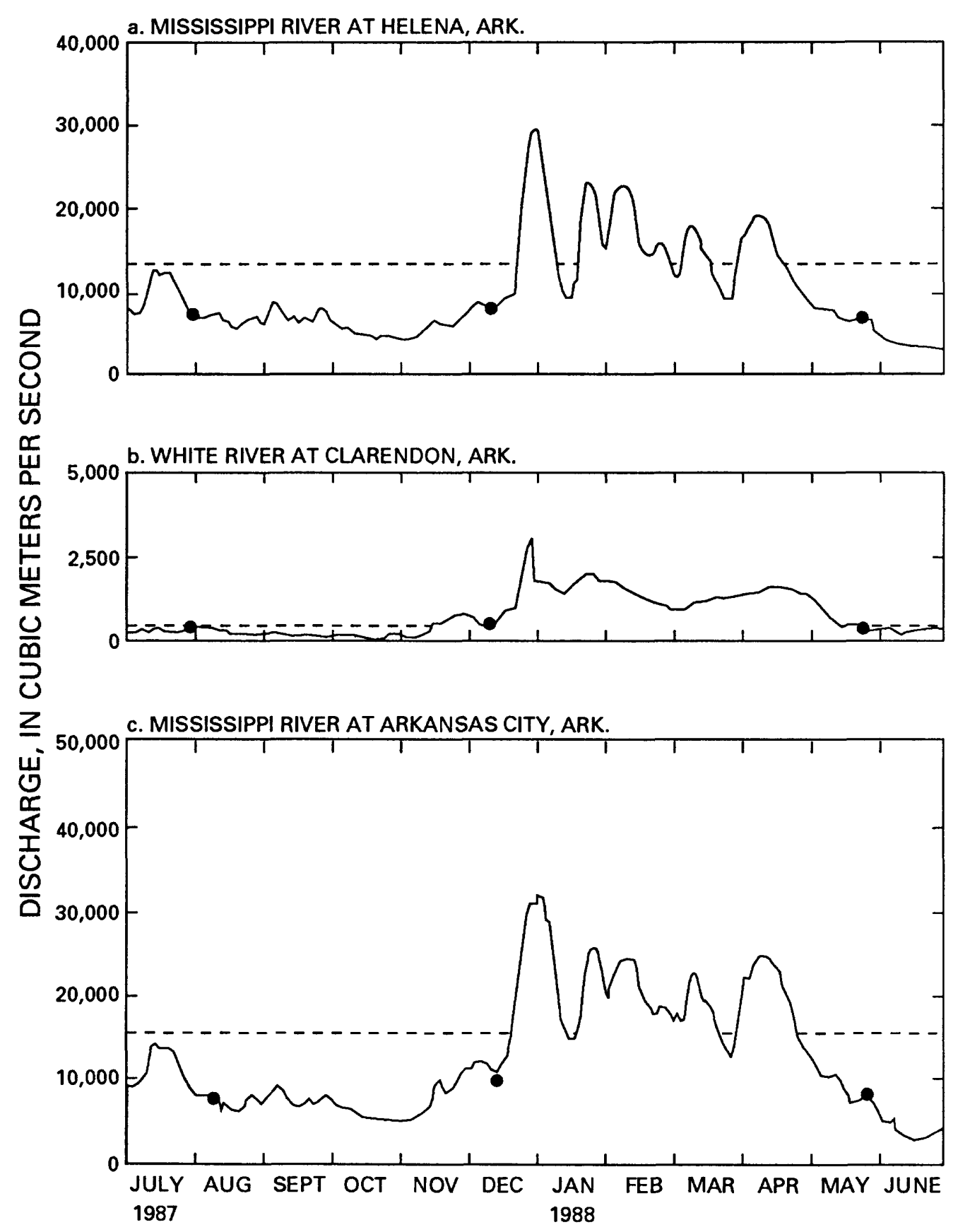

Figure 5.--Value of daily water discharges at selected sampling sections from July 1, 1987, to June 31,1988 . The day each section was measured (see tables 9,10 , and 11 for measured discharges) is shown as a solid dot. Dashed line is the mean discharge based on at least 49 years of record. Based on discharge data of the U.S. Army Corps of Engineers, Memphis and Vicksburg Districts.

a. Mississippi River at Helena, Ark.

b. White River at Clarendon, Ark, about 80 miles upriver of sampling section

c. Mississippi River at Arkansas City, Ark. 


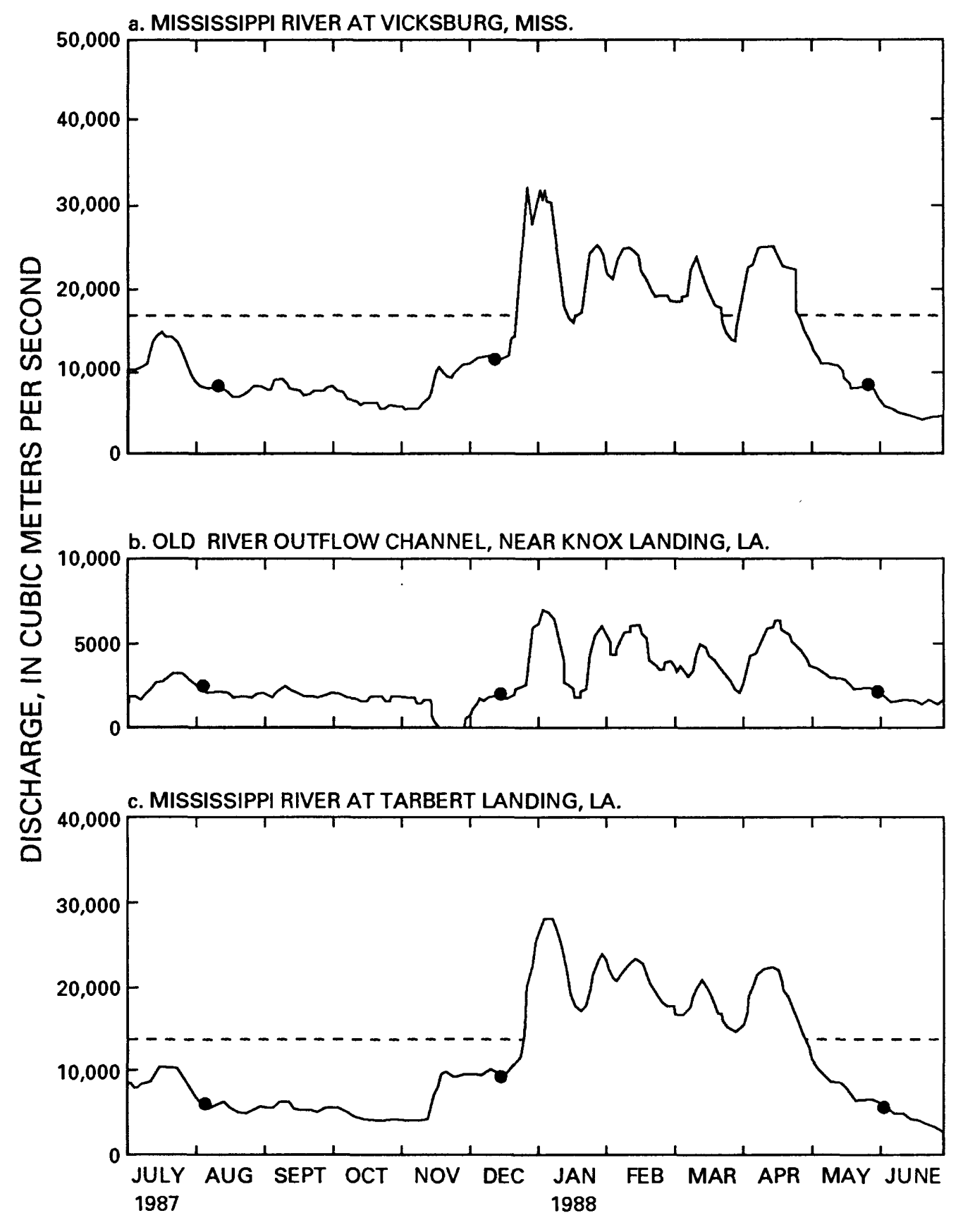

Figure 6.--Value of daily water discharges at selected sampling sections from July 1, 1987, to June 31,1988 . The day each section was measured (see tables 9, 10, and 11 for measured discharges) is shown as a solid dot. Dashed line is the mean discharge based on at least 49 years of record. Based on discharge data of the U.S. Army Corps of Engineers, Vicksburg and New Orleans Districts.

a. Mississippi River at Vicksburg, Miss.

b. Old River Outflow Channel, near Knox Landing, La .

c. Mississippi River at Tarbert Landing, La., 40 miles upriver from St. Francisville, La. 


\section{BED SEDIMENTS}

A BM-54 sampler (Guy and Norman, 1970, p. 15) was used to collect bedsediment samples for physical and chemical analyses. At the beginning of the measurement of each section, while equipment was being set up for the waterdischarge measurement and suspended-sediment sampling, the ship drifted downstream; when it crossed the line of section, a bed-sediment sample was taken for physical analysis and as soon as possible a second sample was taken for chemical analysis. A fathometer (Lowrance, Model X16) ${ }^{1}$ was used to obtain a continuous record of depth; at the time each bed sample was taken, a mark was made on this continuous trace of the river bottom. Samples were collected at approximately $0.25,0.50$, and 0.75 of the distance between left and right banks during the first and second cruises (tables 3 and 4). During the third cruise bed samples were collected at approximately $0.1,0.3,0.5,0.7$, and 0.9 of the distance between the left and right banks (table 5).

${ }^{1}$ The use of brand, trade, or firm names in this report is for identification purposes only and does not constitute endorsement by the U.S. Geological Survey. 
Table 3.--particle size, determined by sieving, of sediment collected from the beds of the Mississippi River and its principal tributaries, July 20 to August 9, 1987

[Analyses by M.J. Werito and J.A. Moody]

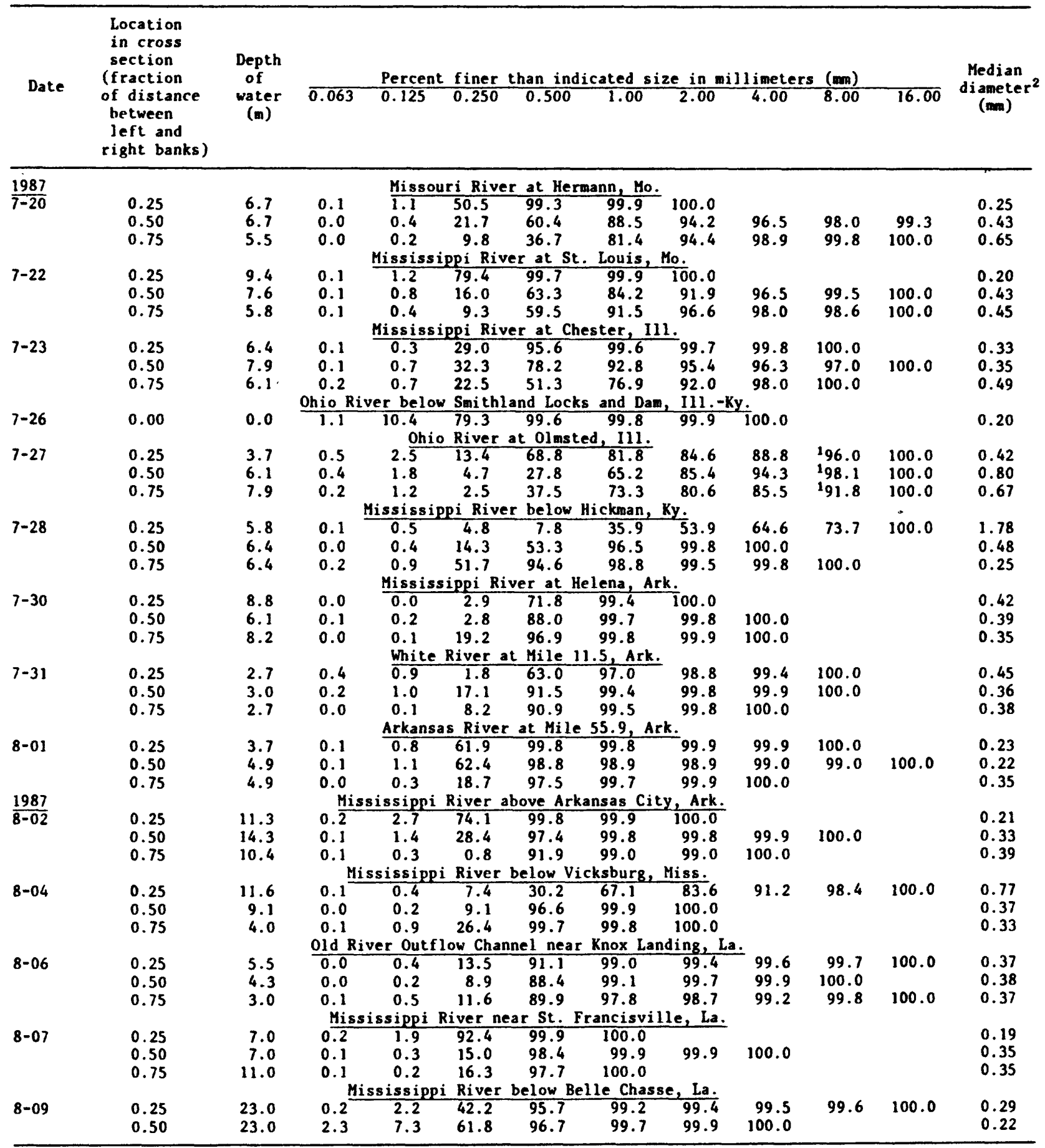

${ }^{1}$ Clamshell fragments were larger than $16 \mathrm{~mm}$.

${ }^{2}$ Median diameter determined by straight-line interpolation. 
Table 4,--particle size, determined by sieving, of sediment collected from the beds of the ississippi River and its principal tributaries, November 30 to December 20, 1987

[Analyses by M.J. Werito]

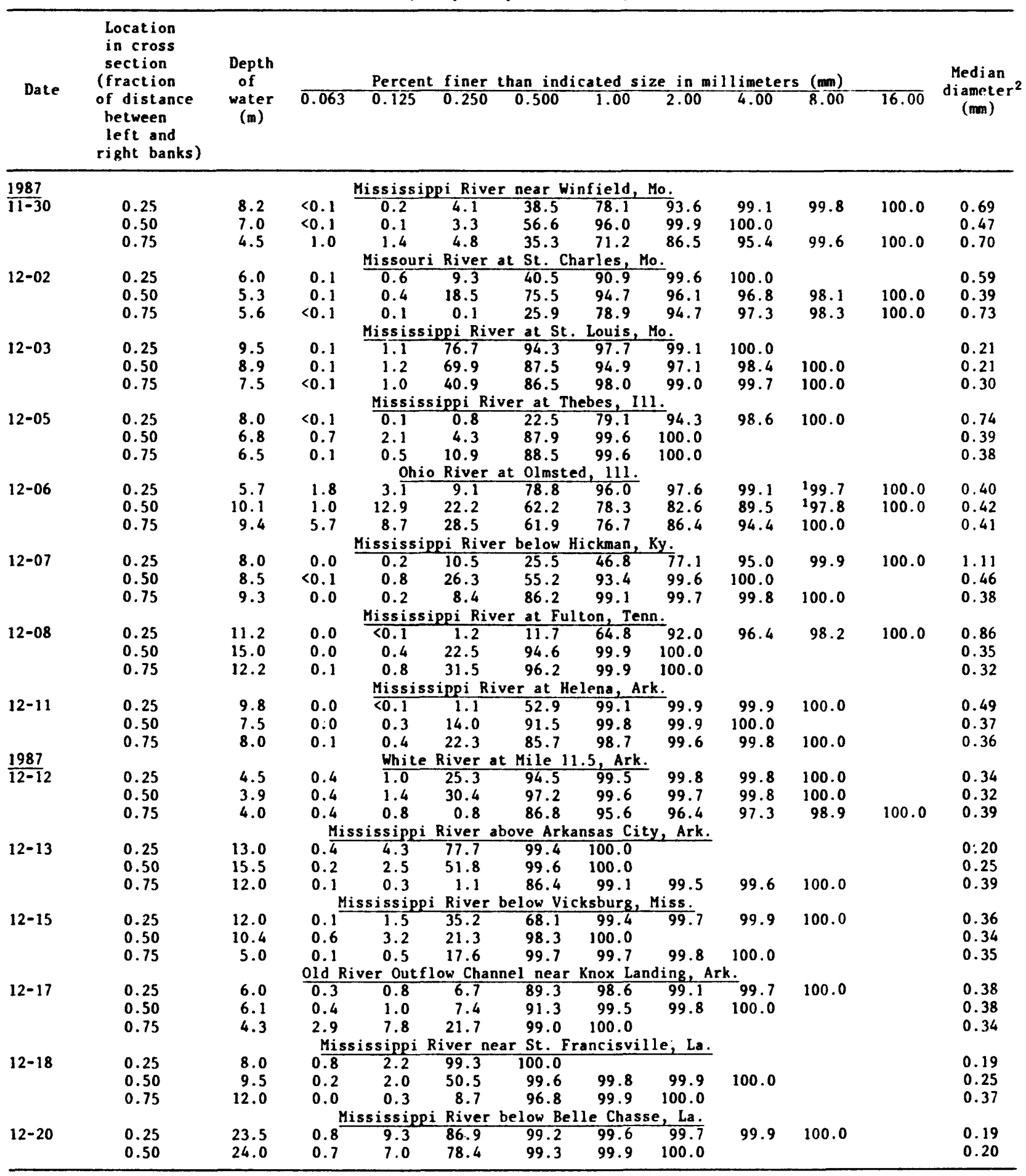

${ }^{1} \mathrm{Clamshell}$ fragments were larger than $16 \mathrm{~mm}$.

2 Median diameter determined by straight-line interpolation. 
Table 5.--Particle size, determined by sieving, of sedinent collected from the beds of the mississippi River and its principal tributaries, way 16 to Jume 7,1988

[Analyses by M.J. Werito]

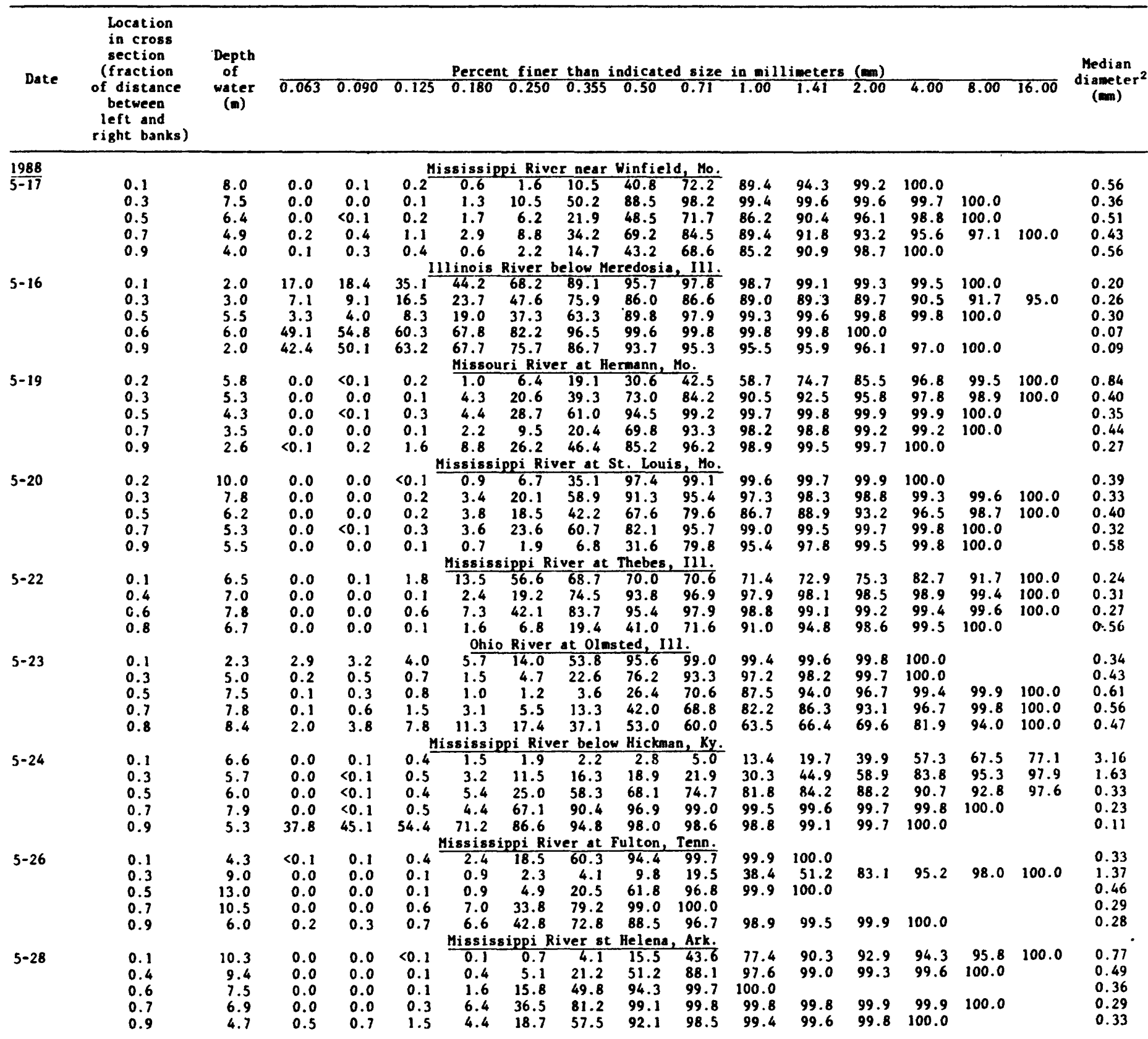


Table 5,--Particle size, determined by sieving, of sedinent collected from the beds of the Mississippi River and its principal tributaries, may 16 to Jume 7, 1988--Continued

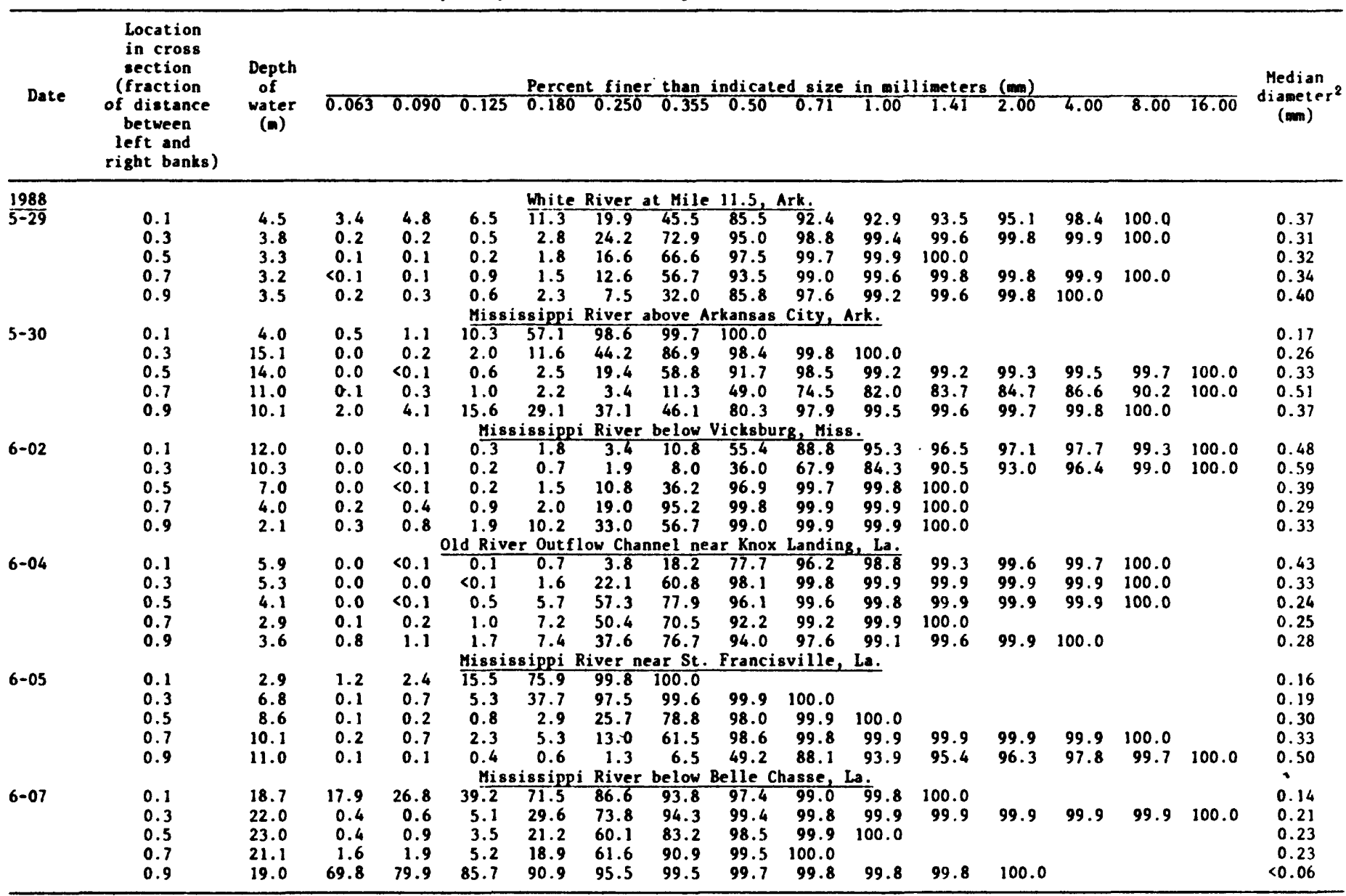

${ }^{1}$ Gravel sizes contained mostly gastropod and bivalve shell fragaents.

Median diameter determined by straight-line interpolation. 
The mean velocity at each vertical was measured by depth integration as the suspended-sediment sampler and current meter (fig. 7) were lowered from the surface to the bottom at a constant transit rate and then immediately upon

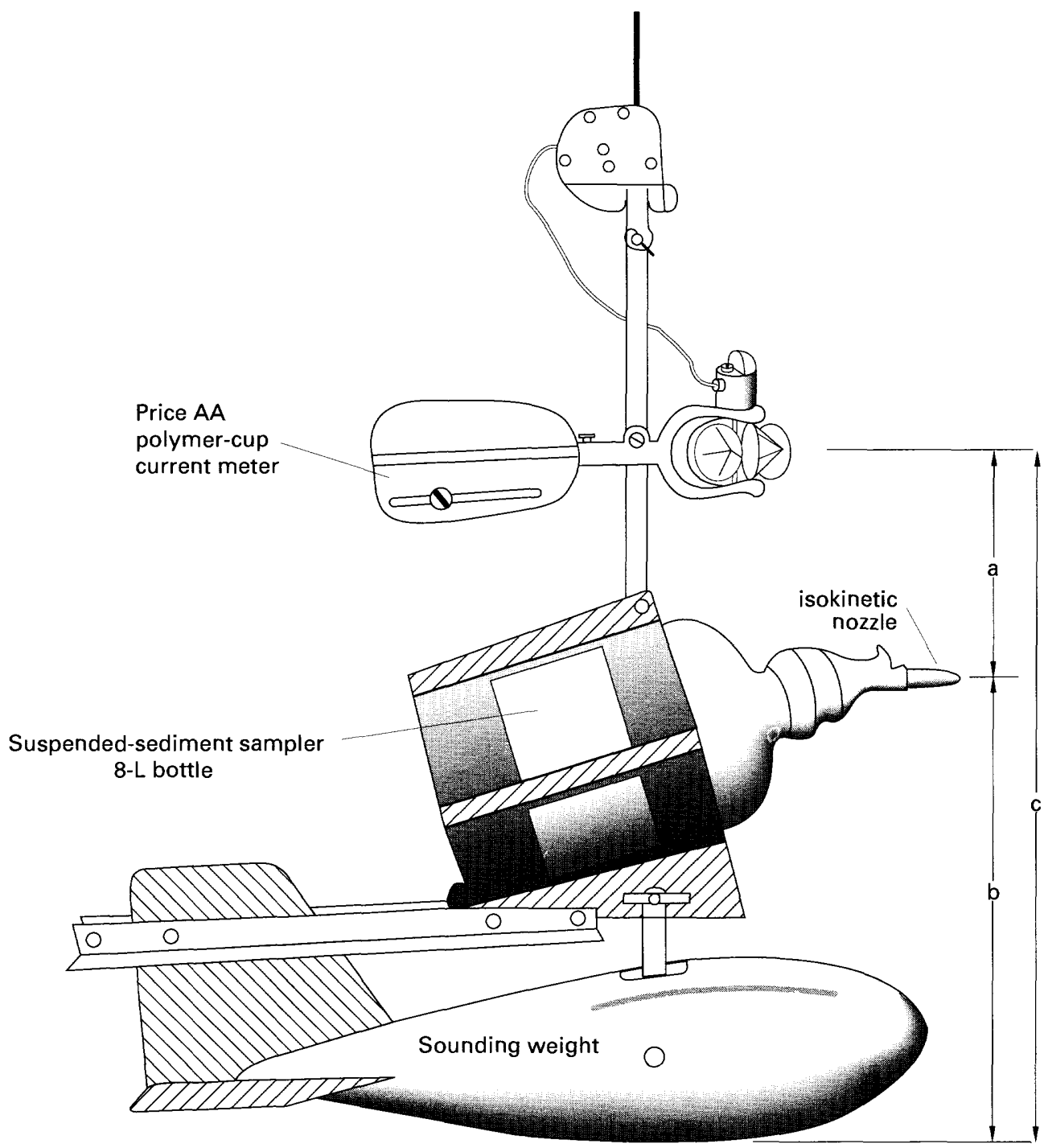

DISTANCE, IN CENTIMETERS

\begin{tabular}{|c|c|c|c|}
\hline WEIGHT, IN POUNDS & a & b & c \\
\hline 150 & 22 & 42 & 64 \\
200 & 22 & $45(42)$ & 67 \\
300 & $22(27)$ & 48 & $70(75)$ \\
\hline
\end{tabular}

Figure 7.--Suspended-sediment sampler with current meter. Value in parenthesis for $b$ and $c$, opposite $200 \mathrm{lbs}$. is for the July-August 1987 cruise. Value in parenthesis for a and c, opposite 300 lbs. is for the Mississippi River at Hickman, Fulton, and Helena during the November-December 1987 cruise. 
touching the bottom, the sampler and current meter were raised at the same constant transit rate to the surface. Ideally, for discharge measurements, the transit rate should be as slow as possible so that the integration time is as long as possible. However, at very slow transit rates, the suspendedsediment sampler would overfill. The transit rate was therefore determined by the requirements for collecting 90 to $100 \mathrm{~L}$ of water and suspended sediment (see Nordin and others, 1983) and for keeping the transit rate less than 20 percent of the mean flow in order to obtain a reliable mean velocity and hence discharge measurement (see tables 6,7 , and 8 for a listing of transit rates used at each section).

Since the ship usually was not anchored during the vertical sampling procedure, the measured velocities were corrected for ship drift (Nordin and others, 1983; Moody and Troutman, in press) by using two microwave transmitter/receiver stations on shore and a master station (Del Norte Technology Trisponder system) aboard the ship to measure the change in upriver-downriver position and cross-river position. The mean depth was obtained from the fathometer which produced a continuous strip-chart record of depth during the down- and upcast. In the Mississippi River, 30 to 40 equally spaced vertical locations typically were occupied to collect suspended-sediment samples and to measure water discharge. At some sections (especially those with asymmetrical cross sections) additional verticals were occupied (tables 6,7 , and 8 ) in order to obtain additional velocity measurements in areas where the discharge per unit width was large. Even though no suspended-sediment sample was collected at these extra verticals, a sample bottle was put in the holder so that the current-meter calibration was not altered. For the July-August 1987, and for part of the November-December 1987 cruises, the mean velocity was computed as the average of the down- and upcasts (referred to as $Q_{\text {initial }}$ ). We eventually realized that the current meter was in the turbulent shadow, of the relatively large sampling bottle on

Table 6.--statistics of the vertical depth-integration mothod which was used to collect suspended sediment, July 18 to August 9,1987

$I V_{c}$ is the total volume collected by depth integration; $V_{d}$ is the total volume dewatered $=$ total volume collected minus the aliquots taken by each research project]

\begin{tabular}{|c|c|c|c|c|c|c|c|c|c|}
\hline \multirow[b]{2}{*}{ Date } & \multirow[b]{2}{*}{ River and section } & \multirow{2}{*}{$\begin{array}{c}\text { Number } \\
\text { of } \\
\text { verticals }\end{array}$} & \multirow{2}{*}{$\begin{array}{l}\text { Length } \\
\text { of } \\
\text { section } \\
\text { (hr) }\end{array}$} & \multirow{2}{*}{$\begin{array}{l}\text { Time } \\
\text { per } \\
\text { vertical } \\
\text { (min) }\end{array}$} & \multirow{2}{*}{$\begin{array}{c}\text { Average } \\
\text { transit } \\
\text { rate } \\
(\mathrm{cm} / \mathrm{s})\end{array}$} & \multirow{2}{*}{$\begin{array}{c}\text { Mean } \\
\text { water } \\
\text { velocity } \\
(\mathrm{cm} / \mathrm{s})\end{array}$} & \multirow{2}{*}{$\begin{array}{c}\text { Nozzle } \\
\text { diameter } \\
\text { (inch) }\end{array}$} & \multicolumn{2}{|c|}{ - Volume } \\
\hline & & & & & & & & $\begin{array}{l}v_{c} \\
(L)\end{array}$ & $v_{d}$ \\
\hline $\begin{array}{l}7987 \\
7-19 \\
7-18 \\
7-21 \\
7-20 \\
7-22\end{array}$ & $\begin{array}{l}\text { Mississippi R. near Winfield, Mo. } \\
\text { Illinois R. below Meredosia, Ill. } \\
\text { Mississippi R. at Hartford, Ill. } \\
\text { Missouri R. at Hermann, Mo. } \\
\text { Mississippi R. at St. Louis, Mo. }\end{array}$ & $\begin{array}{l}1 \\
1 \\
35 \\
28 \\
30\end{array}$ & $\begin{array}{l}\text { No } \\
\text { No } \\
3.27 \\
3.90 \\
3.10\end{array}$ & \multicolumn{3}{|c|}{$\begin{array}{l}\text { depth-integrated } \\
\text { depth-integrated }\end{array}$} & $\begin{array}{c}\text { sample } \\
\text { sample } \\
5 / 16 \\
1 / 4 \\
1 / 4\end{array}$ & $\begin{array}{l}92.0 \\
92.0 \\
98.8 \\
64.1 \\
91.1\end{array}$ & $\begin{array}{r}192.0 \\
192.0 \\
93.2 \\
58.4 \\
85.4\end{array}$ \\
\hline $\begin{array}{l}7-23 \\
7-26 \\
7-27 \\
7-28 \\
7-30\end{array}$ & $\begin{array}{l}\text { Mississippi R. at Chester, } 111 \text {. } \\
\text { Ohio R. below Smithland Locks and Dam, I11.-Ky. } \\
\text { Ohio R. at Olmsted, Ill. } \\
\text { Mississippi R. below Hickman, Ky. } \\
\text { Mississippi R. ot Helena, Ark. }\end{array}$ & $\begin{array}{l}30 \\
18 \\
28 \\
30 \\
30\end{array}$ & $\begin{array}{l}2.85 \\
\text { No } \\
6.78 \\
3.57 \\
3.60\end{array}$ & $\begin{array}{l}5.7 \\
\text { depth-int } \\
14.5 \\
7.1 \\
7.2\end{array}$ & $\begin{array}{c}14 \\
\text { grated } \\
5 \\
10 \\
12\end{array}$ & $\begin{array}{c}112 \\
\text { sample } \\
42 \\
102 \\
144\end{array}$ & $\begin{array}{l}1 / 4 \\
5 / 16 \\
5 / 16 \\
1 / 4 \\
1 / 4\end{array}$ & $\begin{array}{r}71.0 \\
290.9 \\
88.4 \\
87.0 \\
112.1\end{array}$ & $\begin{array}{r}65.3 \\
86.1 \\
82.0 \\
81.4 \\
104.5\end{array}$ \\
\hline $\begin{array}{l}7-31 \\
8-1 \\
8-2 \\
8-4 \\
8-6\end{array}$ & $\begin{array}{l}\text { White R. at Mile } 11.5 \text {, Ark. } \\
\text { Arkansas R. at Mile } 55.9 \text {, Ark. } \\
\text { Mississippi R. above Arkansas City, Ark. } \\
\text { Mississippi R. below Vicksburg, Miss. } \\
\text { Old R. Outflow Channel near Knox Landing, La. }\end{array}$ & $\begin{array}{l}20 \\
40 \\
30 \\
36 \\
26\end{array}$ & $\begin{array}{l}2.85 \\
4.43 \\
4.77 \\
4.70 \\
3.90\end{array}$ & $\begin{array}{l}8.6 \\
6.6 \\
9.5 \\
7.8 \\
9.0\end{array}$ & $\begin{array}{r}6 \\
9 \\
9 \\
7 \\
11\end{array}$ & $\begin{array}{l}67 \\
65 \\
78 \\
95 \\
95\end{array}$ & $\begin{array}{l}5 / 16 \\
5 / 16 \\
3 / 16 \\
3 / 16 \\
5 / 16\end{array}$ & $\begin{array}{r}102.7 \\
93.5 \\
89.6 \\
83.6 \\
90.7\end{array}$ & $\begin{array}{l}96.7 \\
87.4 \\
84.0 \\
77.8 \\
85.4\end{array}$ \\
\hline $\begin{array}{l}8-7 \\
8-9\end{array}$ & $\begin{array}{l}\text { Mississippi R. near St. Francisville, La. } \\
\text { Mississippi R. below Belle Chasse, La. }\end{array}$ & $\begin{array}{r}32 \\
2 \\
18 \\
5\end{array}$ & $\begin{array}{l}3.02 \\
0.13 \\
3.87 \\
0.67\end{array}$ & $\begin{array}{r}5.7 \\
3.9 \\
12.9 \\
8.0\end{array}$ & $\begin{array}{r}9 \\
10 \\
10 \\
20\end{array}$ & $\begin{array}{l}\text { No } \\
\text { data } \\
\text { for } \\
\text { velocity }\end{array}$ & $\begin{array}{l}1 / 4 \\
1 / 4 \\
5 / 16 \\
\text { none }\end{array}$ & $\begin{array}{r}84.0 \\
4.3 \\
56.5 \\
30.1\end{array}$ & $\begin{array}{l}78.4 \\
\text { none } \\
\text { none } \\
86.3\end{array}$ \\
\hline
\end{tabular}

'Sample was collected by pumping from a small boat at anchor.

${ }^{2}$ Sample was collected by lowering the sampler into the water and steaning forward to create flow. 
Table 7.--statistics of the vertical depth-integration method which was used to collect suspended sedinent, November 29 to December 20, 1987

IV $V_{c}$ is the total volune collected by depth integration; $V_{d}$ is the total volune dewatered = total volume collected ainus the aliquots taken by each research project]

\begin{tabular}{|c|c|c|c|c|c|c|c|c|c|}
\hline \multirow[b]{2}{*}{ Date } & \multirow[b]{2}{*}{ River and section } & \multirow{2}{*}{$\begin{array}{l}\text { Number } \\
\text { of } \\
\text { verticals }\end{array}$} & \multirow{2}{*}{$\begin{array}{l}\text { Length } \\
\text { of } \\
\text { section } \\
\text { (hr) }\end{array}$} & \multirow{2}{*}{$\begin{array}{l}\text { Time } \\
\text { per } \\
\text { vertical } \\
\text { (min) }\end{array}$} & \multirow{2}{*}{$\begin{array}{c}\text { Average } \\
\text { transit } \\
\text { rate } \\
(\mathrm{cm} / \mathrm{s})\end{array}$} & \multirow{2}{*}{$\begin{array}{c}\text { Mean } \\
\text { water } \\
\text { velocity } \\
(\mathrm{cw} / \mathrm{s})\end{array}$} & \multirow{2}{*}{$\begin{array}{l}\text { Nozzle } \\
\text { diameter } \\
\text { (inch) }\end{array}$} & \multicolumn{2}{|c|}{ Volune } \\
\hline & & & & & & & & $\begin{array}{l}v_{c} \\
(L)\end{array}$ & $v_{d}$ \\
\hline $\begin{array}{l}\frac{1987}{11-30} \\
11-29\end{array}$ & $\begin{array}{l}\text { Mississippi R. near Winfield, Mo. } \\
\text { Illinois R. below Meredosia, Ill. }\end{array}$ & $\begin{array}{r}29 \\
7 \\
14\end{array}$ & $\begin{array}{l}4.76 \\
0.76 \\
2.54\end{array}$ & $\begin{array}{r}9.8 \\
6.5 \\
10.9\end{array}$ & $\begin{array}{l}6 \\
4 \\
6\end{array}$ & $\begin{array}{l}64 \\
36 \\
37\end{array}$ & $\begin{array}{l}1 / 4 \\
5 / 16 \\
\text { none }\end{array}$ & $\begin{array}{l}92.1 \\
22.1 \\
66.8\end{array}$ & $\begin{array}{r}85.8 \\
122.1 \\
166.8\end{array}$ \\
\hline $\begin{array}{l}12-02 \\
12-03 \\
12-05 \\
12-06 \\
12-07\end{array}$ & $\begin{array}{l}\text { Missouri. R. at St. Charles, Mo. } \\
\text { Mississippi R. at St. Louis, Mo. } \\
\text { Mississippi R. at Thebes, IIl. } \\
\text { Ohio R. at Olested, Ill. } \\
\text { Mississippi R. below Hicknan, Ky. }\end{array}$ & $\begin{array}{l}28 \\
30 \\
30 \\
30 \\
30\end{array}$ & $\begin{array}{l}4.55 \\
5.38 \\
4.63 \\
4.92 \\
4.04\end{array}$ & $\begin{array}{r}9.8 \\
10.8 \\
9.3 \\
9.8 \\
8.1\end{array}$ & $\begin{array}{r}10 \\
16 \\
17 \\
7 \\
14\end{array}$ & $\begin{array}{r}121 \\
129 \\
131 \\
55 \\
111\end{array}$ & $\begin{array}{l}1 / 4 \\
1 / 4 \\
1 / 4 \\
5 / 16 \\
1 / 4\end{array}$ & $\begin{array}{r}96.1 \\
112.1 \\
83.0 \\
115.7 \\
94.4\end{array}$ & $\begin{array}{r}90.7 \\
98.5 \\
78.3 \\
109.5 \\
87.6\end{array}$ \\
\hline $\begin{array}{l}12-08 \\
12-11 \\
12-12 \\
12-13 \\
12-14\end{array}$ & $\begin{array}{l}\text { Mississippi R. at Fulton, Tenn. } \\
\text { Mississippi R. at Helena, Ark. } \\
\text { White R. at Mile } 11.5 \text {, Ark. } \\
\text { Mississippi R. above Arkansas, City, Ark. } \\
\text { Yazoo R. at Mile 10, Miss. }\end{array}$ & $\begin{array}{l}30 \\
30 \\
20 \\
30 \\
20\end{array}$ & $\begin{array}{l}4.68 \\
3.63 \\
6.28 \\
5.98 \\
4.32\end{array}$ & $\begin{array}{r}9.4 \\
7.3 \\
18.8 \\
12.0 \\
13.0\end{array}$ & $\begin{array}{r}12 \\
21 \\
10 \\
13 \\
6\end{array}$ & $\begin{array}{r}116 \\
147 \\
73 \\
100 \\
33\end{array}$ & $\begin{array}{l}3 / 16 \\
1 / 4 \\
5 / 16 \\
3 / 16 \\
\text { none }\end{array}$ & $\begin{array}{r}95.1 \\
89.5 \\
110.5 \\
85.0 \\
87.1\end{array}$ & $\begin{array}{r}89.3 \\
83.6 \\
105.6 \\
79.0 \\
75.8\end{array}$ \\
\hline $\begin{array}{l}12-15 \\
12-17 \\
12-18 \\
12-20\end{array}$ & $\begin{array}{l}\text { Mississippi } R \text {. below Vicksburg, Miss. } \\
\text { Old R. Outflow Channel near Knox Landing, La. } \\
\text { Mississippi R. near St. Francisville, La. } \\
\text { Mississippi R. below Belle Chasse, La. }\end{array}$ & $\begin{array}{l}36 \\
32 \\
32 \\
20\end{array}$ & $\begin{array}{l}5.89 \\
4.05 \\
3.55 \\
4.86\end{array}$ & $\begin{array}{r}9.8 \\
7.6 \\
6.7 \\
14.6\end{array}$ & $\begin{array}{r}12 \\
9 \\
13 \\
10\end{array}$ & $\begin{array}{r}109 \\
63 \\
93 \\
61\end{array}$ & $\begin{array}{l}3 / 16 \\
5 / 16 \\
1 / 4 \\
1 / 4\end{array}$ & $\begin{array}{r}82.2 \\
99.1 \\
107.9 \\
98.9\end{array}$ & $\begin{array}{r}76.0 \\
93.1 \\
101.9 \\
92.9\end{array}$ \\
\hline
\end{tabular}

'Aliquots taken from separate individual depth-integrated samples collected after the 22.15-L and 66.81-L samples were collected.

Table 8.--statistics of the vertical depth-integration method which was used to collect suspended sediment, Nay 14 to June 7,1988

I $V_{c}$ is the total volume collected by depth integration; $V_{d}$ is the total volume dewatered = total volume collected minus the aliquots taken by each research project; and $V_{p}$ is the total volume collected by pumping at mid-depth or at 5 meters depth (whichever was smaller) directly into the centrifuge. A second value in this column is the portion of the pumped volume that was collected from the outlet of the centrifuge and processed through the ultrafilter]

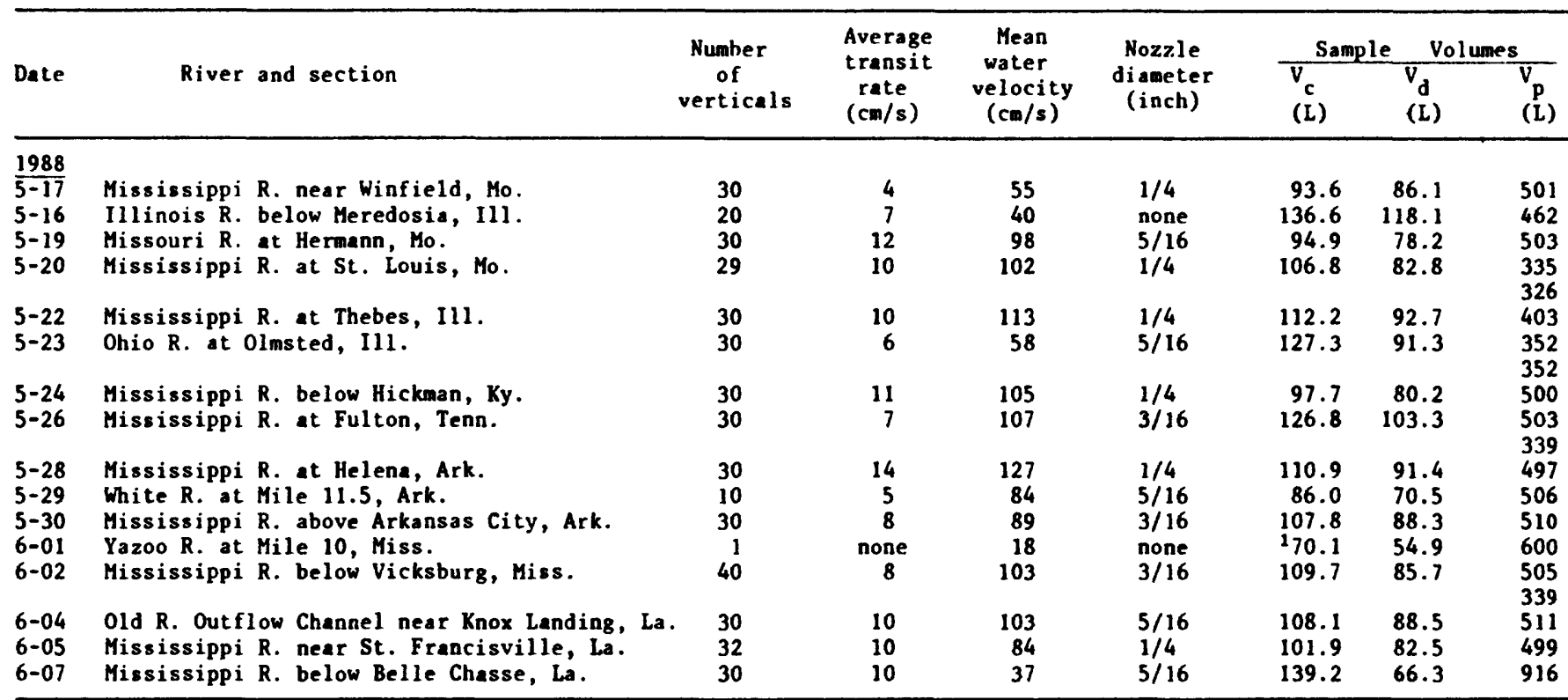

${ }^{1}$ Surface dip sample collected from a small boat slowly moving upriver. 
the downcast but not on the upcast, so that the upcast velocity, $\bar{U}_{u p}$, was probably more accurate (Moody and Troutman, in press). The turbulent shadow has its greatest effect at faster transit rates, $R_{t}$, resulting in greater deviations of $Q_{\text {initial }}$ from the final discharge, $Q_{f i n a l}$, (based only on the upcast mean velocity). In figure 8 , the ratio $\mathrm{Tr}$, equal to $\mathrm{Q}_{\text {final }} / \mathrm{Q}_{\text {initial }}$, is plotted versus the discharge-weighted mean ratio of $R_{t} / \bar{U}_{u p}$ for cross sections where both the downcast and upcast velocities were measured. The discharge-weighted mean ratio of $R_{t} / \bar{U}$ was then computed for the sections without upcast measurements during the July-August 1987 and November-December 1987 cruises. The corresponding value of $\mathrm{Tr}$ was then taken from the graph in figure 8 , assuming that $R_{t} / \bar{U}=R_{t} / \bar{U}_{u p}$. The final discharge equals the initial discharge times $\operatorname{Tr}$. Values of $\operatorname{Tr}$ are listed in table 9 for the July-August 1987 cruise and in table 10 for the November-December 1987 cruise in addition to the mean velocity and the initial and final discharges. The summary of discharge measurements of the May-June 1988 cruise is in table 11. A more detailed discussion of the depth-integration method of measuring water discharge is given by Moody and Troutman (in press).

Seven discharge measurements made by the depth-integration method, during the November-December 1987 and May-June 1988 cruises, were compared with seven simultaneous discharge measurements made by personnel from the U.S. Geological Survey and the U.S. Army Corps of Engineers using the $0.2,0.8$, and 0.4 methods. The largest difference between these simultaneous measurements was 9 percent, the average difference was \pm 4 percent, and the standard error was 5 percent.

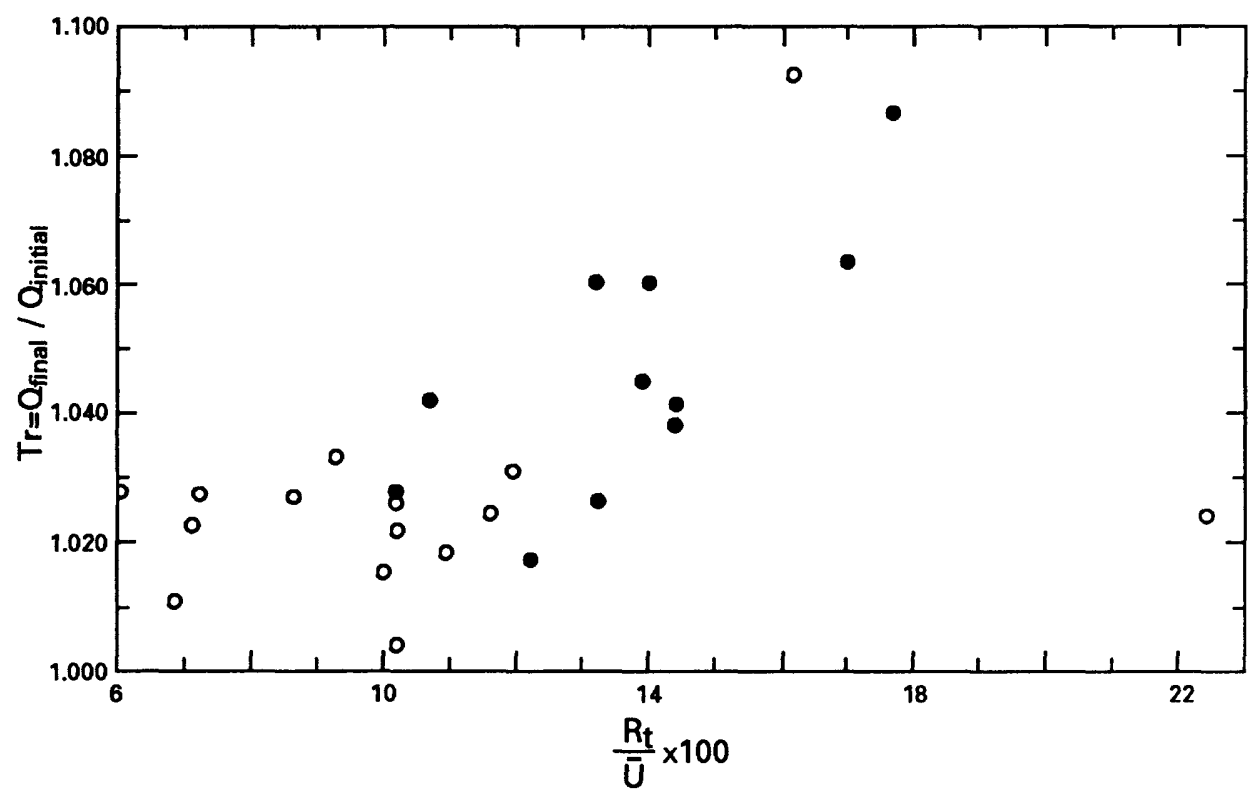

Figure 8.--Correlation between the vertical transit rate, $R_{t}$, expressed as a percent of measured mean velocity, $\bar{U}_{\text {up' }}$ on the upcast and the ratio, $\operatorname{Tr}$, of the final discharge to the average down- and upcast discharge. Solid circles are data from the November-December 1987 cruise and the open circles are data from the May-June 1988 cruise. 
Table 9.--sumery of discharge weasurements ande using the depth-integration method from the R/V ACNDIANA between July 18 - August 9, 1987

(All velocity measurements were made with a Price solid polymer bucket-wheel current meter (Ho. P8308282; calibration equation was velocity $($ in $a / s)=0.784 *$ revolutions/sec +0.028$)$. The initial discharge listed below is the average of the downcast and upcast. Since the current meter is in the shadow of the sampling bottle on the downcast, the measurements were corrected to upcast velocity. The final discharge equals the initial discharge times $\mathrm{Tr}$, the transit-rate correcting factor. See the text and figure 8 for explanation of $\mathrm{Tr}$. Discharges and a reas have been rounded to three significant figures]

\begin{tabular}{|c|c|c|c|c|c|c|c|c|}
\hline Date & River and section & $\begin{array}{l}\text { Mean } \\
\text { depth' } \\
(\omega)\end{array}$ & $\begin{array}{l}\text { Width } \\
\text { (D) }\end{array}$ & $\begin{array}{c}\text { Area } \\
\left(\mathbf{a}^{2}\right)\end{array}$ & $\begin{array}{l}\text { Mean } \\
\text { velocity } \\
(\varpi / 8)\end{array}$ & Tr & $\frac{\text { Disc }}{\text { Initial }}$ & $\frac{\text { harge }}{\text { Final }}$ \\
\hline$\frac{1987}{7-19}$ & Mississippi R. near Winfield, Ho. & No & \multicolumn{3}{|c|}{ depth-integrated } & \multicolumn{2}{|c|}{ measurewent } & ${ }^{3} 1,370$ \\
\hline $7-18$ & Illinois R. below Meredosia, Ill. & No & \multicolumn{3}{|c|}{ depth-integrated } & \multicolumn{2}{|c|}{ measurement } & 4312 \\
\hline $7-21$ & Mississippi R. at Hartford, Ill. & 8.0 & 359 & 2,860 & 0.52 & 1.09 & 1,380 & 1,500 \\
\hline $7-20$ & Missouri R. at Hermann, Ho. & 5.6 & 377 & 2,130 & 1.24 & 1.03 & 2,560 & 2,640 \\
\hline $7-22$ & Mississippi R. at St. Louis, Mo. & 7.3 & 482 & 3,540 & 1.11 & 1.03 & 3,830 & 3,940 \\
\hline $7-23$ & Mississippi R. at Chester, Ill. & 6.5 & 591 & 3,820 & 1.11 & 1.04 & 4,090 & 4.250 \\
\hline $7-26$ & Ohio R. below Saithland Locks and Daw, IIl.-Ky. & No & \multicolumn{2}{|c|}{ depth-integrated } & \multicolumn{2}{|c|}{ measure- } & 5652 & ment \\
\hline $7-27$ & Ohio R. at Olmsted, Ill. & 5.4 & 930 & 4,980 & 0.42 & 1.05 & 1,970 & 2,070 \\
\hline $7-28$ & Mississippi R. below Hicknan, Ky. & 6.1 & 995 & 6,080 & 1.03 & 1.03 & 6,090 & 6,270 \\
\hline $7-30$ & Mississippi R. at Helena, Ark. & 6.7 & 701 & 4,730 & 1.45 & 1.02 & 6,720 & 6,850 \\
\hline $7-31$ & White $R$. at Mile 11.5, Ark. & 2.9 & 168 & 490 & 0.68 & 1.03 & 322 & 332 \\
\hline 8-01 & Arkansas R. at Mile 55.9, Ark. & 4.0 & 313 & 1,240 & 0.64 & 1.05 & 750 & 790 \\
\hline 8-02 & Mississippi R. above Arkansas City, Ark. & 11.4 & 850 & 9,730 & 0.78 & 1.04 & 7,340 & 7,630 \\
\hline 8-04 & Mississippi R. below Vicksburg, Miss. & 7.1 & 1,131 & 8,080 & 0.96 & 1.02 & 7,600 & 7,750 \\
\hline $8-06$ & Old R. Outflow Channel near Knox Landing, La. & 4.1 & 519 & 2,120 & 0.97 & 1.04 & 1,970 & 2,050 \\
\hline $8-07$ & Mississippi R. near St. Francisville, La. & 7.6 & 983 & 7,460 & 0.83 & 1.04 & 65,950 & 6,190 \\
\hline $8-09$ & Mississippi R. below Belle Chasse, La. & No & \multicolumn{2}{|c|}{ discharge } & meast & ment & was & made \\
\hline
\end{tabular}

IMean depth equals the area divided by the width.

${ }^{2}$ Mean velocity is equal to the final discharge divided by the area.

$(495 \mathrm{~s} / \mathrm{s})$.

${ }^{3}$ Estimated discharge equals Mississippi River at Keokuk $\left(875 \mathrm{~m}^{3} / \mathrm{s}\right)$ plus Des Moines River at Keosauqua

Computed daily discharge frow U.S. Geological Survey Illinois district data.

SDischarge was estimated by difference: Ohio River at 010 ted minus combined discharge $\left(1,416 \mathrm{~m}^{3} / \mathrm{s}\right)$ from the Kentucky Dam (Tennessee River) and the Barkley Dam (Cumberland River).

${ }^{6}$ An open-cup Price type AA current meter was used with a calibration equation: velocity (in $\mathrm{m} / \mathrm{s}$ ) = $0.694 *$ revolutions/sec +0.002 . Mean velocities measured by this meter at five verticals in the $01 d$ River Outflow Channel near Knox Landing on August 6, 1987 (see table 9), were about $5 \%$ bigher than the velocities measured by the Price solid polymer bucket wheel. The discharge was adjusted by multiplyiag the discharge, as cslculated from the open-cup velocity measurements, by 0.95 . 
Table 10.--Sumary of discharge measurements made using the depth-integration method from the R/V ACADIANA between November 29 - December 20, 1987

[The calibration equations were determined using a 150-pound sounding weight and were assumed to be the same for a 300-pound sounding weight. The initial discharge listed below is the average of the downcast and upcast. Since the current meter is in the shadow of the sampling bottle on the downcast, the downcast velocities were corrected to upcast velocities. The final discharge equals the initial discharge times.Tr (the transit-rate correcting factor). See the text and figure 8 for explanation of $T r$. Discharges and areas have been rounded to three significant figures]

\begin{tabular}{|c|c|c|c|c|c|c|c|c|}
\hline Date & River and section & $\begin{array}{l}\text { Mean } \\
\text { depth } \\
\text { (m) }\end{array}$ & $\begin{array}{c}\text { Width } \\
\text { (m) }\end{array}$ & $\begin{array}{l}\text { Area } \\
\left(m^{2}\right)\end{array}$ & $\begin{array}{l}\text { Mean } \\
\text { veloc ity } \\
(\mathrm{m} / \mathrm{s})\end{array}$ & $\mathrm{Tr}$ & $\frac{\text { Dischar }}{\text { Initial }}$ & $\frac{8 e}{\text { Fnal }}$ \\
\hline$\frac{1987}{11-30}$ & Mississippi R. near Winfield, Mo. & 6.2 & 519 & 3,200 & 0.64 & 1.02 & 2,000 & 2,040 \\
\hline $11-29$ & Illinois R. below Meredosia, Ill. & -- & -- & -- & $-\infty$ & $=-$ & $\cdots$ & ${ }^{3} 262$ \\
\hline $12-02$ & Missouri R. at St. Charles, Mo. & 5.3 & 428 & 2,270 & 1.24 & 1.02 & 2,750 & 2,810 \\
\hline $12-03$ & Mississippi R. at St. Louis, Mo. & 7.9 & 511 & 4,060 & 1.34 & 1.04 & 5,230 & 5,440 \\
\hline $12-05$ & Mississippi R. at Thebes, III. & 6.6 & 574 & 3,800 & 1.37 & 1.04 & 4,990 & 5,190 \\
\hline $12-06$ & Ohio R. at Olmsted, Ill. & 7.8 & 974 & 7,620 & 0.55 & 1.00 & 4,200 & 4,200 \\
\hline $12-07$ & Mississippi R. below Hickman, Ky. & 7.9 & 1,008 & 7,970 & 1.11 & 1.00 & 8,820 & 8,820 \\
\hline $12-08$ & Mississippi R. at Fulton, Tenn. & 9.7 & 844 & 8,160 & 1.16 & 1.00 & 9,470 & 9,470 \\
\hline $12-11$ & Mississippi R. at Helena, Ark. & 8.0 & 750 & 5,970 & 1.47 & 1.00 & 8,770 & 8,770 \\
\hline $12-12$ & White R. at Mile 11.5, Ark. & 4.0 & 177 & 711 & 0.73 & 1.00 & 519 & 519 \\
\hline $12-13$ & Mississippi R. above Arkansas City, Ark. & 11.0 & 904 & 9,950 & 1.00 & 1.00 & 9,920 & 9,920 \\
\hline $12-14$ & Yazoo R. at Mile 10, Miss. & 4.5 & 120 & 540 & 0.33 & 1.00 & 177 & 177 \\
\hline $12-15$ & Mississippi R. below Vicksburg, Miss. & 8.3 & 1,153 & 9,560 & 1.09 & 1.00 & 10,410 & 10,410 \\
\hline $12-17$ & Old R. Outflow Channel near Knox Landing, La. & 5.5 & 525 & 2,910 & 0.63 & 1.00 & 1,830 & 1,830 \\
\hline $12-18$ & Mississippi R. near St. Francisville, La. & 9.0 & 970 & 8,770 & 0.93 & 1.00 & 8,180 & 8,180 \\
\hline $12-20$ & Mississippi R. below Belle Chasse, La. & 20.3 & 776 & 15,740 & 0.61 & 1.00 & 9,560 & 49,560 \\
\hline
\end{tabular}

Mean depth equals the area divided by the width.

${ }^{2}$ The mean velocity is equal to the final discharge divided by the area. Three different calibration equations were used to compute the mean vertical velocity at each vertical using a Price AA solid polymer bucket-wheel current meter (No. P8308282):

\begin{tabular}{|c|c|c|}
\hline $\begin{array}{l}\text { Sections } \\
\text { kman, Fulton, Helena } \\
\text { ansas City, Vicksburg } \\
\text { other sections }\end{array}$ & $\begin{array}{c}\text { Calibration date } \\
4-14-88 \\
4-12-88 \\
4-07-88\end{array}$ & $\begin{array}{l}\quad \text { Equation } \\
V(\mathrm{~m} / \mathrm{s})=0.759 \div \mathrm{rev} / \mathrm{s}+0.010 \\
V(\mathrm{~m} / \mathrm{s})=0.774 \div \mathrm{rev} / \mathrm{s}+0.027 \\
V(\mathrm{~m} / \mathrm{s})=0.780^{\circ} \mathrm{rev} / \mathrm{s}+0.005\end{array}$ \\
\hline
\end{tabular}

${ }^{3}$ Computed daily discharge from the U.S. Geological Survey Illinois district data.

${ }^{4}$ Discharge may be affected by the tide because the river stage was very low. 
Table 11.--Summary of discharge measurements made using the depth-integration wethod from the R/V ACADIANA between May 16 - June 7, 1988

(All velocity measurements were made with a Price solid polymer bucket-wheel current meter (No. P8308282, calibration equation was velocity $($ in $\mathrm{m} / \mathrm{s})=0.774 *$ revolutions $/ \mathrm{sec}+0.003)$. Discharges and areas have been rounded to 3 significant figures]

\begin{tabular}{|c|c|c|c|c|c|c|}
\hline Date & River and section & $\begin{array}{l}\text { Mean } \\
\text { depth } \\
\text { (n) }\end{array}$ & $\begin{array}{c}\text { Width } \\
\text { (a) }\end{array}$ & $\begin{array}{l}\text { Area } \\
\left(m^{2}\right)\end{array}$ & $\begin{array}{l}\text { Mean } \\
\text { velocity } \\
(\mathrm{m} / \mathrm{s})\end{array}$ & $\begin{array}{c}\text { Discharge } \\
\left(m^{3} / s\right)\end{array}$ \\
\hline$\frac{1988}{5-17}$ & Mississippi R. near Winfield, Mo. & 5.8 & 547 & 3,180 & 0.55 & 1,740 \\
\hline $5-16$ & Illinois R. below Meredosia, IIl. & 3.6 & 228 & 823 & 0.40 & 332 \\
\hline $5-19$ & Missouri R. at Hermann, Mo. & 4.3 & 350 & 1,510 & 0.98 & 1,480 \\
\hline $5-20$ & Mississippi R. at st. Louis, Mo. & 6.8 & 487 & 3,290 & 1.02 & 3,350 \\
\hline $5-22$ & Mississippi R. at Thebes, Mo. & 6.1 & 525 & 3,220 & 1.11 & 3,590 \\
\hline $5-23$ & Ohio R. at Olmsted, III. & 5.9 & 945 & 5,530 & 0.58 & 3,230 \\
\hline $5-24$ & Mississippi R. below Hickman, Mo. & 6.5 & 991 & 6,480 & 1.05 & 6,790 \\
\hline $5-26$ & Mississippi R. at Fulton, Tenn. & 8.4 & 805 & 6,730 & 1.07 & 7,170 \\
\hline $5-28$ & Mississippi R. at Helena, Ark. & 7.4 & 754 & 5,550 & 1.27 & 7,050 \\
\hline $5-29$ & White R. at Mile 11.5, Ark. & 3.2 & 164 & 520 & 0.84 & 438 \\
\hline $5-30$ & Mississippi R. above Arkansas City, Ark. & 11.0 & 838 & 9,180 & 0.89 & 8,160 \\
\hline $6-01$ & Yazoo R. at Mile 10, Miss. & 4.2 & 100 & 418 & 0.17 & 373 \\
\hline $6-02$ & Mississippi R. below Vicksburg, Miss. & 6.8 & 1,129 & 7,690 & 1.03 & 7,950 \\
\hline $6-04$ & Old R. Outflow Channel near Knox Landing, La. & 4.1 & 515 & 2,090 & 1.03 & 2,150 \\
\hline $6-05$ & Mississippi R. near St. Francisville, La. & 7.6 & 900 & 6,830 & 0.83 & 5,700 \\
\hline $6-07$ & Mississippi R. below Belle Chasse, La. & 19.3 & 778 & 15,030 & 0.37 & 5,570 \\
\hline
\end{tabular}

1Mean depth equals the area divided by the width.

2 Mean velocity is equal to the discharge divided by the area.

3 Measured by Bishop and Phillips (U.S. Geological Survey, Mississippi District) using a Price AA open metal cup meter \#2808 from a small boat on a tagline. 


\section{SUSPENDED SEDIMENT}

The equal-width-increment (equal-transit-rate), depth-integration method (Nordin and others, 1983; Richey and others, 1986; Meade and Stevens, 1990) was used to collect discharge-weighted suspended-sediment samples at 10-40 verticals per cross section (tables 6, 7, and 8). A collapsible-bag sampler (Stevens and others, 1980) fitted with an isokinetic nozzle (Guy and Norman, 1970 , p. 8-10) collected suspended sediment in sand, silt, and clay sizes (see tables 6,7 , and 8 for nozzle diameters). The sampler was held in a frame so that the nozzle was horizontal (fig. 7) and about $45 \mathrm{~cm}$ above the bottom of a sounding weight. A Price AA current meter with a solid polymer cup was mounted $22 \mathrm{~cm}$ above the nozzle of the sampler. The current meter was used to determine the nozzle efficiency and to measure the mean velocity for computing water and sediment discharge. The vertical transit rate was controlled by a hydraulic winch, which was able to produce the same and constant rate for the downcast as well as for the upcast. The same transit rate was reproduced (to within $1 \mathrm{~cm} / \mathrm{s}$ ) for each vertical in the cross section by setting the transit rate with a hand-held tachometer at the beginning of the downcast and at the beginning of the upcast. The multiple gears on the hydraulic system allowed transit rates as slow as $4 \mathrm{~cm} / \mathrm{s}$ and as fast as $21 \mathrm{~cm} / \mathrm{s}$ (tables 6,7 , and 8 ).

Two 8-L plastic bottles with collapsible fluorinated-ethylene-propylene (FEP) Teflon bags and Teflon nozzles were used in the isokinetic sampler to collect separate composite samples identified as A and B. Bottle A was used to collect the odd-numbered verticals and bottle $B$ the even-numbered verticals. The $A$ and $B$ samples were poured into separate glass, graduated cylinders through separate nickel-mesh $63-\mu \mathrm{m}$ sieves to remove the sand. The water volume collected at each vertical was measured (see section "Tabulated Cruise Data") and then added to separate $A$ and B Teflon-coated, stainless-steel, churn splitters. Leenheer and others (1989) describe the Teflon bags, nickel sieves, and churn splitters in more detail and discuss the evaluation of materials considered for the fabrication of each item so that they would meet the diverse requirements for trace-organic, trace-metal, and suspendedsediment analysis.

Aliquots were taken from the $A$ and $B$ composites for suspended-sediment concentration, trace-metal, trace-organic, mineral composition and nutrient analyses. Three aliquots (approximately 150-250 mL) were taken from each composite to measure the suspended-sediment concentration of material finer than $63 \mu \mathrm{m}$. Each of the six aliquots was filtered through paired, pre-weighed Millipore $\mathrm{HA}$ filters $\left(0.45-\mu \mathrm{m}\right.$ pore size), dried at $110^{\circ} \mathrm{C}$, and reweighed to give the silt and clay concentrations in tables 12,13 , and 14 . The sand collected in the nickel sieves $A$ and $B$ was dried at $80^{\circ} \mathrm{C}$ and weighed to give the sand concentrations listed in tables 12,13 , and 14 . The sand fraction contained some silt and clay material which was measured during the size analysis. This additional concentration of silt and clay material was added to the mean concentration of silt and clay obtained from the Millipore filter weights and is listed in tables 12,13 , and 14 . The mean range in concentration (calculated from 2-4 filters) was $4 \pm 3$ percent of the mean concentration of silt and clay for July-August 1987 and $3 \pm 2$ percent for November-December 1987 and for May-June 1988. The higher percentage corresponded to the lowest concentrations. The average percent differences between the silt and clay concentrations of composite $A$ and the concentrations of composite $B$ were 2.7 , 
2.5, and 1.7 percent for the July-August 1987, November-December 1987, and the May-June 1988 cruises. The comparison of the concentrations in composites A and $B$ is shown in figure $9 a$ for silt and clay and in figure $9 b$ for sand. The average percent differences between the sand concentrations of composites $A$ and $B$ were $6.4,5.0$, and 7.2 percent for the three cruises. The suspendedsediment concentrations were multiplied by the water discharges listed in

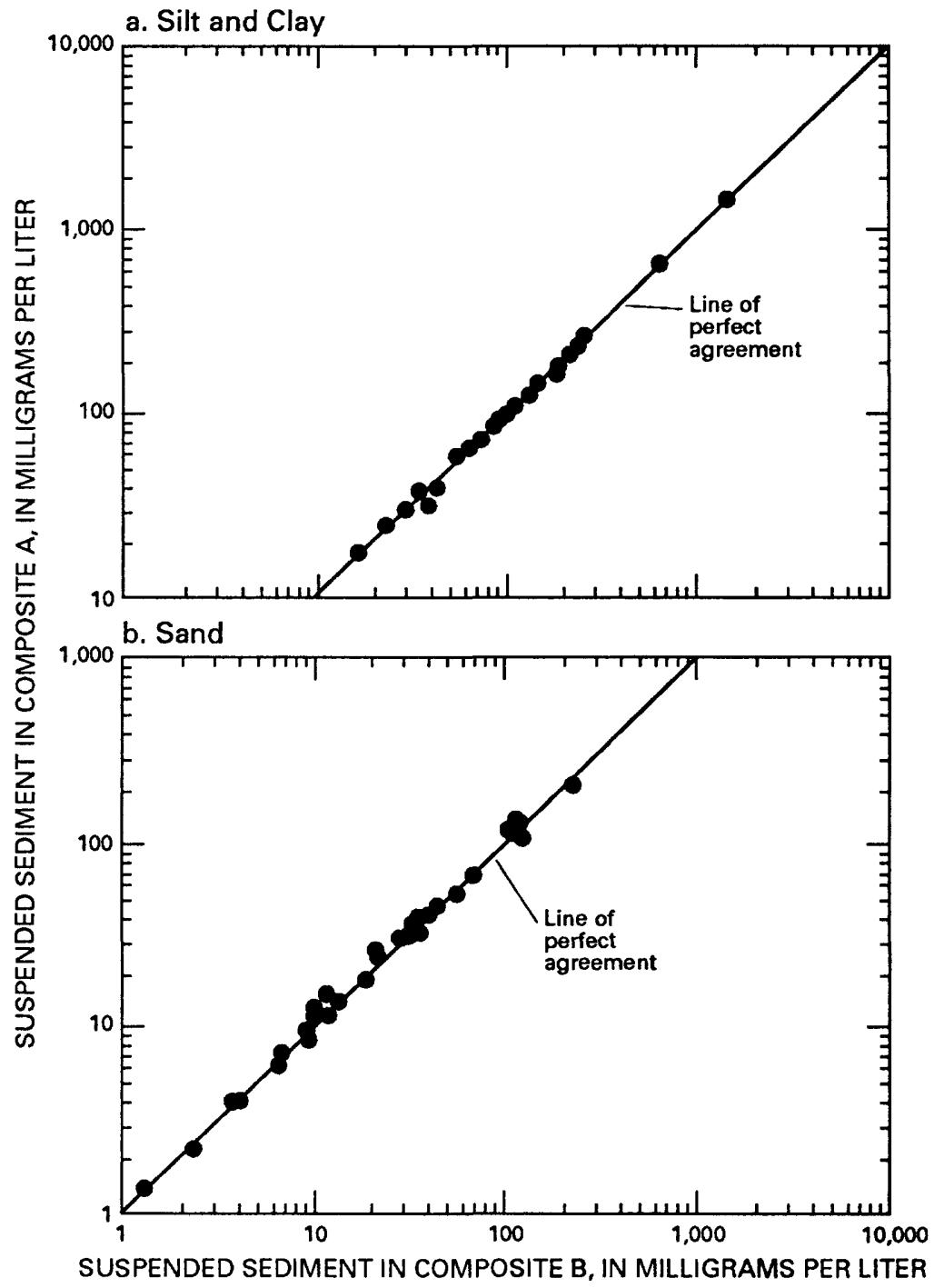

Figure 9.--Comparison of the concentration of the silt and clay fraction (a) and the sand fraction (b) in composite $A$ and composite $B$ for the July-August 1987, November-December 1987, and May-June 1988 cruises (from Meade and Stevens, 1990). The diagonal lines are not regression lines.

tables 9,10 , and 11 , and by a constant (0.0864) to give the sediment discharges, in metric tons per day, listed in tables 12,13 , and 14 . After all aliquots were taken, the $A$ and $B$ composites were combined into a single sample and run through the dewatering procedure described in section "Dewatering of Samples" (see tables, 6, 7, and 8 for a list of volumes collected and dewatered). 
Table 12.--Concentrations of suspended sediwent in composite depth-integrated samples collected in the Mississippi River and principal tributaries and the corresponding sediment discharges,

July 20 to August 9, 1987

[Analyses by R.H. Meade. Water discharges measured by C.C. Cranston, J.A. Moody, and H.H. Stevens. m/L, milligrams per liter; pm, micrometer; ND, no water discharge measurement]

\begin{tabular}{|c|c|c|c|c|c|c|c|c|c|c|}
\hline \multirow[b]{2}{*}{ Date } & \multirow[b]{2}{*}{ River and section } & \multirow[b]{2}{*}{$\begin{array}{l}\text { Com- } \\
\text { pos- } \\
\text { ite }\end{array}$} & \multirow{2}{*}{$\begin{array}{l}\text { Num- } \\
\text { ber } \\
\text { of } \\
\text { ver- } \\
\text { ti- } \\
\text { cals }\end{array}$} & \multirow{2}{*}{$\begin{array}{l}\text { Water } \\
\text { dis- } \\
\text { charge } \\
\left(\mathrm{m}^{3} / \mathrm{s}\right)\end{array}$} & \multicolumn{3}{|c|}{$\begin{array}{l}\text { Sediment concentrations } \\
(\mathrm{mg} / \mathrm{L})\end{array}$} & \multicolumn{3}{|c|}{$\begin{array}{r}\text { Sediment discharge } \\
\text { (metric tons/day) }\end{array}$} \\
\hline & & & & & $\begin{array}{l}\text { Silt } \\
\text { and } \\
\text { clay } \\
<63 \mathrm{~N}\end{array}$ & $\begin{array}{l}\text { Sand } \\
>63 \mathrm{Nom}\end{array}$ & Tolal & $\begin{array}{l}\text { Silt } \\
\text { and } \\
\text { clay } \\
<63 \mathrm{jm}\end{array}$ & $\begin{array}{l}\text { Sand } \\
>63 \mathrm{pm}\end{array}$ & Total \\
\hline$\frac{1987}{7-21}$ & $\begin{array}{l}\text { Mississippi R. at } \\
\text { Hartford, Iil. }\end{array}$ & $\begin{array}{l}A \\
B\end{array}$ & $\begin{array}{l}17 \\
17\end{array}$ & 1,500 & $\begin{array}{l}41 \\
43\end{array}$ & $\begin{array}{l}<0.1 \\
<0.1\end{array}$ & $\begin{array}{l}41 \\
43\end{array}$ & 5,400 & $<10$ & 5,400 \\
\hline $7-20$ & $\begin{array}{l}\text { Missouri R. at } \\
\text { Hermana, Mo. }\end{array}$ & $\begin{array}{l}\text { A } \\
\text { B }\end{array}$ & $\begin{array}{l}14 \\
14\end{array}$ & 2,600 & $\begin{array}{l}1,466 \\
1,465\end{array}$ & $\begin{array}{l}108 \\
112\end{array}$ & $\begin{array}{l}1,574 \\
1,577\end{array}$ & 329,000 & 25,000 & 354,000 \\
\hline $7-22$ & $\begin{array}{l}\text { Mississippi R. at } \\
\text { St. Louis, Mo. }\end{array}$ & $\begin{array}{l}\text { A } \\
\text { B }\end{array}$ & $\begin{array}{l}15 \\
14\end{array}$ & 3,900 & $\begin{array}{l}668 \\
654\end{array}$ & $\begin{array}{l}30 \\
34\end{array}$ & $\begin{array}{l}698 \\
688\end{array}$ & 223,000 & 11,000 & 234,000 \\
\hline $7-23$ & $\begin{array}{l}\text { Mississippi } R . \text { at } \\
\text { Chester, III. }\end{array}$ & $\begin{array}{l}A \\
\mathbf{B}\end{array}$ & $\begin{array}{l}15 \\
15\end{array}$ & 4,300 & $\begin{array}{l}651 \\
658\end{array}$ & $\begin{array}{l}23 \\
21\end{array}$ & $\begin{array}{l}674 \\
679\end{array}$ & 243,000 & 8,200 & 251,000 \\
\hline $7-26$ & $\begin{array}{l}\text { Ohio R. below Smithland } \\
\text { Locks and Dan, IIl.-Ky. }\end{array}$ & & 3 & 630 & 22 & 0 & 22 & 0 & 1,200 & 1,200 \\
\hline $7-27$ & $\begin{array}{l}\text { Ohio R. at } \\
\text { Olmsted, I11. }\end{array}$ & $\begin{array}{l}A \\
B\end{array}$ & $\begin{array}{l}14 \\
14\end{array}$ & 2,100 & $\begin{array}{l}25 \\
24\end{array}$ & $\begin{array}{l}10.3 \\
10.5\end{array}$ & $\begin{array}{l}25 \\
24\end{array}$ & 4,400 & $<50$ & 4,400 \\
\hline $7-28$ & $\begin{array}{l}\text { Mississippi R. below } \\
\text { Hickman, Ky. }\end{array}$ & A & $\begin{array}{l}15 \\
15\end{array}$ & 6,300 & $\begin{array}{l}177 \\
177\end{array}$ & $\begin{array}{l}3 \\
2\end{array}$ & $\begin{array}{l}180 \\
179\end{array}$ & 96,000 & 1,400 & 97,000 \\
\hline $7-30$ & $\begin{array}{l}\text { Mississippi R. at } \\
\text { Helena, Ark. }\end{array}$ & $\begin{array}{l}A \\
\text { B }\end{array}$ & $\begin{array}{l}15 \\
15\end{array}$ & 6,900 & $\begin{array}{l}260 \\
257\end{array}$ & $\begin{array}{l}25 \\
22\end{array}$ & $\begin{array}{l}285 \\
279\end{array}$ & 154,000 & 14,000 & 168,000 \\
\hline $7-31$ & $\begin{array}{l}\text { White } R \text {. at } \\
\text { Mile 11.5, Ark. }\end{array}$ & $\hat{A}$ & $\begin{array}{l}10 \\
10\end{array}$ & 330 & $\begin{array}{l}123 \\
121\end{array}$ & $\begin{array}{l}4 \\
4\end{array}$ & $\begin{array}{l}127 \\
125\end{array}$ & 3,500 & 110 & 3,600 \\
\hline $8-01$ & $\begin{array}{l}\text { Arkansas R. at } \\
\text { Mile 55.9, Ark. }\end{array}$ & $\begin{array}{l}\text { A } \\
\text { B }\end{array}$ & $\begin{array}{l}20 \\
20\end{array}$ & 790 & $\begin{array}{l}24 \\
22\end{array}$ & $\begin{array}{l}1_{0.3} \\
1_{0.3}\end{array}$ & $\begin{array}{l}24 \\
22\end{array}$ & 1,600 & 10 & 1,600 \\
\hline $8-02$ & $\begin{array}{l}\text { Mississippi R. above } \\
\text { Arkansas City, Ark. }\end{array}$ & $\begin{array}{l}\text { A } \\
\text { B }\end{array}$ & $\begin{array}{l}15 \\
15\end{array}$ & 7,600 & $\begin{array}{l}270 \\
263\end{array}$ & $\begin{array}{l}11 \\
11\end{array}$ & $\begin{array}{l}281 \\
274\end{array}$ & 177,000 & 7,200 & 184,000 \\
\hline 8-04 & $\begin{array}{l}\text { Mississippi R. below } \\
\text { Vicksburg, Miss. }\end{array}$ & $\begin{array}{l}\text { A } \\
B\end{array}$ & $\begin{array}{l}18 \\
18\end{array}$ & 7,700 & $\begin{array}{l}215 \\
216\end{array}$ & $\begin{array}{l}8 \\
8\end{array}$ & $\begin{array}{l}223 \\
224\end{array}$ & 143,000 & 5,300 & 148,000 \\
\hline $8-06$ & $\begin{array}{l}\text { old } R \text {. Outflow Channel } \\
\text { near Knox Landing, Ls. }\end{array}$ & $\hat{A}$ & $\begin{array}{l}13 \\
13\end{array}$ & 2,100 & $\begin{array}{l}201 \\
206\end{array}$ & $\begin{array}{l}12 \\
12\end{array}$ & $\begin{array}{l}213 \\
218\end{array}$ & 36,900 & 2,200 & 39,000 \\
\hline 8-07 & $\begin{array}{l}\text { Mississippi } R \text {. near } \\
\text { St. Francisville, La. }\end{array}$ & A & $\begin{array}{l}16 \\
16\end{array}$ & 6,200 & $\begin{array}{l}227 \\
233\end{array}$ & $\begin{array}{l}4 \\
5\end{array}$ & $\begin{array}{l}231 \\
238\end{array}$ & 123,000 & 2,400 & 125,000 \\
\hline $8-09$ & $\begin{array}{l}\text { Mississippi R. below } \\
\text { Belle Chasse, La. }\end{array}$ & & 15 & ND & 66 & ${ }^{1} 0.05$ & 66 & ND & ND & ND \\
\hline
\end{tabular}

'Mostly organic. 
Table 13.--Concentrations of suspended sodiment in composite depth-integrated samples collected in the Mississippi River and principal tributaries and the corresponding sediment discharges, Noverber 29 to December 20, 1987

IAnalyses by R.H. Heade. Water discharges easured by J.A. Hoody and H.H. Stevens. mg/L, milligrams per liter; No, aicrometer]

\begin{tabular}{|c|c|c|c|c|c|c|c|c|c|c|}
\hline \multirow[b]{2}{*}{ Date } & \multirow[b]{2}{*}{ River and section } & \multirow[b]{2}{*}{$\begin{array}{l}\text { Con- } \\
\text { pos- } \\
\text { ite }\end{array}$} & \multirow{2}{*}{$\begin{array}{l}\text { Num- } \\
\text { ber } \\
\text { of } \\
\text { ver- } \\
\text { ti- } \\
\text { cals }\end{array}$} & \multirow{2}{*}{$\begin{array}{c}\text { Water } \\
\text { dis- } \\
\text { charge } \\
\left(m^{3} / 8\right)\end{array}$} & \multicolumn{3}{|c|}{$\begin{array}{c}\text { Sediment concentrations } \\
(\mathrm{ag} / \mathrm{L})\end{array}$} & \multicolumn{3}{|c|}{$\begin{array}{r}\text { Sediment discharge } \\
\text { (metric tons/day) }\end{array}$} \\
\hline & & & & & $\begin{array}{l}\text { Silt } \\
\text { and } \\
\text { clay } \\
<63 \mu\end{array}$ & $\begin{array}{l}\text { Sand } \\
>63 \mu\end{array}$ & Total & $\begin{array}{l}\text { Silt } \\
\text { and } \\
\text { clay } \\
<63 \mathrm{~m}\end{array}$ & $\begin{array}{l}\text { Sand } \\
>63\end{array}$ & Total \\
\hline$\frac{1987}{11-30}$ & $\begin{array}{l}\text { Mississippi R. near } \\
\text { Winfield, Ho. }\end{array}$ & $\begin{array}{l}\mathbf{A} \\
\mathbf{B}\end{array}$ & $\begin{array}{l}15 \\
14\end{array}$ & 2,000 & $\begin{array}{l}32 \\
29\end{array}$ & $\begin{array}{l}0 \\
0\end{array}$ & $\begin{array}{l}32 \\
29\end{array}$ & 5,300 & 0 & 5,300 \\
\hline $11-29$ & $\begin{array}{l}\text { Illinois R. below } \\
\text { Heredosia, I11. }\end{array}$ & & 1 & 260 & 79 & 0 & 79 & 1,800 & 0 & 1,800 \\
\hline $12-02$ & $\begin{array}{l}\text { Missouri R. at } \\
\text { St Charles, Ho. }\end{array}$ & $\begin{array}{l}\mathbf{A} \\
\mathbf{B}\end{array}$ & $\begin{array}{l}14 \\
14\end{array}$ & 2,800 & $\begin{array}{l}264 \\
270\end{array}$ & $\begin{array}{l}211 \\
232\end{array}$ & $\begin{array}{l}475 \\
502\end{array}$ & 65,000 & 54,000 & 119,000 \\
\hline $12-03$ & $\begin{array}{l}\text { Hississippi R. at } \\
\text { St. Louis, Mo. }\end{array}$ & $\begin{array}{l}\mathbf{A} \\
\mathbf{B}\end{array}$ & $\begin{array}{l}15 \\
15\end{array}$ & 5,400 & $\begin{array}{l}210 \\
210\end{array}$ & $\begin{array}{l}137 \\
129\end{array}$ & $\begin{array}{l}347 \\
339\end{array}$ & 98,000 & 62,000 & 160,000 \\
\hline $12-05$ & $\begin{array}{l}\text { Mississippi R. at } \\
\text { Thebes, III. }\end{array}$ & $\begin{array}{l}\mathbf{A} \\
\mathbf{B}\end{array}$ & $\begin{array}{l}15 \\
15\end{array}$ & 5,200 & $\begin{array}{l}192 \\
196\end{array}$ & $\begin{array}{l}111 \\
126\end{array}$ & $\begin{array}{l}303 \\
322\end{array}$ & 87,000 & 53,000 & 140,000 \\
\hline $12-06$ & $\begin{array}{l}\text { Ohio R. at } \\
\text { Olasted, I11. }\end{array}$ & $\begin{array}{l}\mathbf{A} \\
\mathbf{B}\end{array}$ & $\begin{array}{l}15 \\
15\end{array}$ & 4,200 & $\begin{array}{l}39 \\
35\end{array}$ & 0.5 & $\begin{array}{l}40 \\
36\end{array}$ & 13,400 & 200 & 14,000 \\
\hline $12-07$ & $\begin{array}{l}\text { Hississippi R. below } \\
\text { Hickman, } \mathrm{Ky} \text {. }\end{array}$ & $\begin{array}{l}\mathbf{A} \\
\mathbf{B}\end{array}$ & $\begin{array}{l}15 \\
15\end{array}$ & 8,800 & $\begin{array}{l}130 \\
132\end{array}$ & $\begin{array}{l}40 \\
38\end{array}$ & $\begin{array}{l}170 \\
170\end{array}$ & 100,000 & 30,000 & 130,000 \\
\hline $12-08$ & $\begin{array}{l}\text { Hississippi R. at } \\
\text { Fulton, Tenn. }\end{array}$ & $\begin{array}{l}\mathbf{A} \\
\mathbf{B}\end{array}$ & $\begin{array}{l}15 \\
15\end{array}$ & 9,500 & $\begin{array}{l}99 \\
99\end{array}$ & $\begin{array}{l}35 \\
34\end{array}$ & $\begin{array}{l}134 \\
133\end{array}$ & 81,000 & 28,000 & 109,000 \\
\hline $12-11$ & $\begin{array}{l}\text { Mississippi R. at } \\
\text { Helena, Ark. }\end{array}$ & $\begin{array}{l}\mathbf{A} \\
\mathbf{B}\end{array}$ & $\begin{array}{l}15 \\
15\end{array}$ & 8,800 & $\begin{array}{l}106 \\
108\end{array}$ & $\begin{array}{l}70 \\
71\end{array}$ & $\begin{array}{l}176 \\
179\end{array}$ & 81,000 & 54,000 & 135,000 \\
\hline $12-12$ & $\begin{array}{l}\text { White R. at } \\
\text { Mile 11.5, Ark. }\end{array}$ & $\begin{array}{l}\mathbf{A} \\
\mathbf{B}\end{array}$ & $\begin{array}{l}10 \\
10\end{array}$ & 520 & $\begin{array}{l}95 \\
97\end{array}$ & $\begin{array}{l}7 \\
7\end{array}$ & $\begin{array}{l}102 \\
104\end{array}$ & 4,300 & 300 & 4,600 \\
\hline $12-13$ & $\begin{array}{l}\text { Mississippi R. above } \\
\text { Arkansas City, Ark. }\end{array}$ & $\begin{array}{l}\mathbf{A} \\
\mathbf{B}\end{array}$ & $\begin{array}{l}15 \\
15\end{array}$ & 9,900 & $\begin{array}{l}106 \\
108\end{array}$ & $\begin{array}{l}44 \\
41\end{array}$ & $\begin{array}{l}150 \\
149\end{array}$ & 92,000 & 36,000 & 128,000 \\
\hline $12-14$ & $\begin{array}{l}\text { Yazoo R. at } \\
\text { Hile } 10, \text { Miss. }\end{array}$ & $\begin{array}{l}\mathbf{A} \\
\mathbf{B}\end{array}$ & $\begin{array}{l}10 \\
10\end{array}$ & 200 & $\begin{array}{l}150 \\
146\end{array}$ & $\begin{array}{l}0 \\
0\end{array}$ & $\begin{array}{l}150 \\
146\end{array}$ & 2,600 & 0 & 2,600 \\
\hline $12-15$ & $\begin{array}{l}\text { Mississippi R. below } \\
\text { Vicksburg, Hiss. }\end{array}$ & $\begin{array}{l}\mathbf{A} \\
\mathbf{B}\end{array}$ & $\begin{array}{l}18 \\
18\end{array}$ & 10,400 & $\begin{array}{l}113 \\
111\end{array}$ & $\begin{array}{l}52 \\
55\end{array}$ & $\begin{array}{l}165 \\
166\end{array}$ & 101,000 & 48,000 & 149,000 \\
\hline $12-17$ & $\begin{array}{l}\text { Old R. Outflow Channel } \\
\text { near Knox Landing La. }\end{array}$ & $\begin{array}{l}\mathbf{A} \\
\mathbf{B}\end{array}$ & $\begin{array}{l}16 \\
16\end{array}$ & 1,800 & $\begin{array}{l}111 \\
109\end{array}$ & 4 & $\begin{array}{l}115 \\
113\end{array}$ & 17,000 & 600 & 18,000 \\
\hline $12-18$ & $\begin{array}{l}\text { Mississippi R. near } \\
\text { St. Francisville, La. }\end{array}$ & $\begin{array}{l}\mathbf{A} \\
\mathbf{B}\end{array}$ & $\begin{array}{l}16 \\
16\end{array}$ & 8,200 & $\begin{array}{l}117 \\
119\end{array}$ & $\begin{array}{l}36 \\
38\end{array}$ & $\begin{array}{l}153 \\
157\end{array}$ & 84,000 & 26,000 & 110,000 \\
\hline $12-20$ & $\begin{array}{c}\text { Mississippi R. below } \\
\text { Belle Chasse, La. }\end{array}$ & $\begin{array}{l}\mathbf{A} \\
\mathbf{B}\end{array}$ & $\begin{array}{l}10 \\
10\end{array}$ & 9,600 & $\begin{array}{l}66 \\
66\end{array}$ & $\begin{array}{l}1.4 \\
1.3\end{array}$ & $\begin{array}{l}67 \\
67\end{array}$ & 55,000 & 1,100 & 56,000 \\
\hline
\end{tabular}


Table 14.--Concentrations of suspended sediment in composite depth-integrated samples collected in the Mississippi River and principal tributaries and the corresponding sediment discharge,

noy 16 to June 7, 1988

[Analyses by R.H. Meade. Water discharges measured by J.A. Moody and H.H. Stevens. $\square$ g/L, milligrams per liter; m, micrometer]

\begin{tabular}{|c|c|c|c|c|c|c|c|c|c|c|}
\hline \multirow[b]{2}{*}{ Date } & \multirow[b]{2}{*}{ River and section } & \multirow[b]{2}{*}{$\begin{array}{l}\text { Con- } \\
\text { pos- } \\
\text { ite }\end{array}$} & \multirow{2}{*}{$\begin{array}{l}\text { Num- } \\
\text { ber } \\
\text { of } \\
\text { ver- } \\
\text { ti- } \\
\text { cals }\end{array}$} & \multirow{2}{*}{$\begin{array}{l}\text { Water } \\
\text { dis- } \\
\text { charge } \\
\left(m^{3} / 8\right)\end{array}$} & \multicolumn{3}{|c|}{$\begin{array}{c}\text { Sediment concentrations } \\
\left(\mathrm{ag}_{\mathrm{R}} / \mathrm{L}\right)\end{array}$} & \multicolumn{3}{|c|}{$\begin{array}{l}\text { Sediment discharge } \\
\text { (metric tons/day) }\end{array}$} \\
\hline & & & & & $\begin{array}{l}\text { Silt } \\
\text { and } \\
\text { clay } \\
<63 \mu \text { a }\end{array}$ & $\begin{array}{l}\text { Sand } \\
>63 \mathrm{~mm}\end{array}$ & Total & $\begin{array}{l}\text { Silt } \\
\text { and } \\
\text { clay } \\
<63 \mu\end{array}$ & $\begin{array}{l}\text { Sand } \\
>63 \mathrm{ma}\end{array}$ & Total \\
\hline$\frac{1988}{5-17}$ & $\begin{array}{l}\text { Mississippi R. near } \\
\text { Winfield, Mo. }\end{array}$ & $\begin{array}{l}\mathbf{A} \\
\mathbf{B}\end{array}$ & $\begin{array}{l}15 \\
15\end{array}$ & 1,700 & $\begin{array}{l}34 \\
34\end{array}$ & $\begin{array}{l}0 \\
0\end{array}$ & $\begin{array}{l}34 \\
34\end{array}$ & 5,000 & 0 & 5,000 \\
\hline 5-16 & $\begin{array}{l}\text { Illinoi-s, R. below } \\
\text { Meredosia, IIl. }\end{array}$ & $\begin{array}{l}\mathbf{A} \\
\mathbf{B}\end{array}$ & $\begin{array}{l}8 \\
9\end{array}$ & 330 & $\begin{array}{l}58 \\
57\end{array}$ & $\begin{array}{l}0 \\
0\end{array}$ & $\begin{array}{l}58 \\
57\end{array}$ & 1,600 & 0 & 1,600 \\
\hline $5-19$ & $\begin{array}{l}\text { Missouri R. at } \\
\text { Hermenn, Ho. }\end{array}$ & $\hat{\mathbf{A}}$ & $\begin{array}{l}15 \\
15\end{array}$ & 1,500 & $\begin{array}{l}79 \\
79\end{array}$ & $\begin{array}{l}46 \\
45\end{array}$ & $\begin{array}{l}125 \\
124\end{array}$ & 10,200 & 5,900 & 16,000 \\
\hline $5-20$ & $\begin{array}{l}\text { Mississippi R. at } \\
\text { St. Louis, Ho. }\end{array}$ & $\begin{array}{l}\mathbf{A} \\
\mathbf{B}\end{array}$ & $\begin{array}{l}15 \\
14\end{array}$ & 3,300 & $\begin{array}{l}66 \\
65\end{array}$ & $\begin{array}{l}13 \\
14\end{array}$ & $\begin{array}{l}79 \\
79\end{array}$ & 19,000 & 3,800 & 23,000 \\
\hline $5-22$ & $\begin{array}{l}\text { Mississippi R. at } \\
\text { Thebes, III. }\end{array}$ & $\hat{\mathbf{A}}$ & $\begin{array}{l}15 \\
15\end{array}$ & 3,600 & $\begin{array}{l}73 \\
75\end{array}$ & $\begin{array}{l}28 \\
27\end{array}$ & $\begin{array}{l}101 \\
102\end{array}$ & 23,000 & 8,600 & 32,000 \\
\hline $5-23$ & $\begin{array}{l}\text { Ohio R. at } \\
\text { Olasted, III. }\end{array}$ & $\hat{\mathbf{A}}$ & $\begin{array}{l}15 \\
15\end{array}$ & 3,200 & $\begin{array}{l}32 \\
31\end{array}$ & $\begin{array}{l}2 \\
2\end{array}$ & $\begin{array}{l}34 \\
33\end{array}$ & 8,700 & 550 & 9,300 \\
\hline $5-24$ & $\begin{array}{l}\text { Mississippi R. below } \\
\text { Hickman, Ky. }\end{array}$ & $\begin{array}{l}\mathbf{A} \\
\mathbf{B}\end{array}$ & $\begin{array}{l}15 \\
15\end{array}$ & 6,800 & $\begin{array}{l}61 \\
58\end{array}$ & $\begin{array}{l}12 \\
10\end{array}$ & $\begin{array}{l}73 \\
68\end{array}$ & 35,000 & 6,500 & 42,000 \\
\hline $5-26$ & $\begin{array}{l}\text { Mississippi R. at } \\
\text { Fulton, Tenn. }\end{array}$ & $\hat{\mathbf{A}}$ & $\begin{array}{l}15 \\
15\end{array}$ & 7,200 & $\begin{array}{l}68 \\
67\end{array}$ & $\begin{array}{l}13 \\
12\end{array}$ & $\begin{array}{l}81 \\
79\end{array}$ & 42,000 & 7.800 & 50,000 \\
\hline $5-28$ & $\begin{array}{l}\text { Mississippi R. at } \\
\text { Helena, Ark. }\end{array}$ & $\begin{array}{l}\mathbf{A} \\
\mathbf{B}\end{array}$ & $\begin{array}{l}15 \\
15\end{array}$ & 7,100 & $\begin{array}{l}76 \\
75\end{array}$ & $\begin{array}{l}32 \\
32\end{array}$ & $\begin{array}{l}108 \\
107\end{array}$ & 46,000 & 20,000 & 66,000 \\
\hline $5-29$ & $\begin{array}{l}\text { White R. at } \\
\text { Mile 11.5, Ark. }\end{array}$ & $\begin{array}{l}\mathbf{A} \\
\mathbf{B}\end{array}$ & $\begin{array}{l}10 \\
10\end{array}$ & 440 & $\begin{array}{l}95 \\
96\end{array}$ & 5 & $\begin{array}{l}100 \\
100\end{array}$ & 3,600 & 170 & 3,800 \\
\hline $5-30$ & $\begin{array}{l}\text { Mississippi R. above } \\
\text { Arkansas City, Ark. }\end{array}$ & $\hat{\mathbf{A}}$ & $\begin{array}{l}15 \\
15\end{array}$ & 8,200 & $\begin{array}{l}87 \\
87\end{array}$ & $\begin{array}{r}9 \\
10\end{array}$ & $\begin{array}{l}96 \\
97\end{array}$ & 61,600 & 6,700 & 68,000 \\
\hline $6-01$ & $\begin{array}{l}\text { Yazoo R. at } \\
\text { Mile 10, Hiss. }\end{array}$ & $\begin{array}{r}\text { Surface } \\
\text { sampl }\end{array}$ & $e_{\text {dip }}^{\text {dip }}$ & 70 & 72 & 0 & 72 & 440 & 0 & 440 \\
\hline $6-02$ & $\begin{array}{l}\text { Mississippi R. below } \\
\text { Vicksburg, Hiss. }\end{array}$ & $\hat{\mathbf{A}}$ & $\begin{array}{l}20 \\
20\end{array}$ & 8,000 & $\begin{array}{l}80 \\
79\end{array}$ & $\begin{array}{l}12 \\
10\end{array}$ & $\begin{array}{l}92 \\
89\end{array}$ & 55,000 & 7,600 & 63,000 \\
\hline $6-04$ & $\begin{array}{l}\text { old } R \text {. Out flow Channel } \\
\text { near Knox Landing, La. }\end{array}$ & $\hat{\mathbf{A}}$ & $\begin{array}{l}15 \\
15\end{array}$ & 2,200 & $\begin{array}{l}74 \\
73\end{array}$ & $\begin{array}{l}30 \\
27\end{array}$ & $\begin{array}{l}104 \\
100\end{array}$ & 14,000 & 5,400 & 19,000 \\
\hline $6-05$ & $\begin{array}{l}\text { Mississippi R. near } \\
\text { St. Francisville, La. }\end{array}$ & $\begin{array}{l}\mathbf{A} \\
\mathbf{B}\end{array}$ & $\begin{array}{l}15 \\
15\end{array}$ & 5,700 & $\begin{array}{l}211 \\
216\end{array}$ & $\begin{array}{l}3 \\
5\end{array}$ & $\begin{array}{l}214 \\
221\end{array}$ & 105,000 & 2,000 & 107,000 \\
\hline $6-07$ & $\begin{array}{l}\text { Mississippi R. below } \\
\text { Belle Chasse, La. }\end{array}$ & $\begin{array}{l}\mathbf{A} \\
\mathbf{B}\end{array}$ & $\begin{array}{l}20 \\
10\end{array}$ & 5,600 & $\begin{array}{l}18 \\
17\end{array}$ & $\begin{array}{l}0 \\
0\end{array}$ & $\begin{array}{l}18 \\
17\end{array}$ & 8,500 & 0 & 8,500 \\
\hline
\end{tabular}


During the third cruise (May 16 to June 7,1988 ) a pumping method was developed for collecting large volumes of water and suspended sediment (300-900 L). A 12-mm-diameter, perfluorinated-alkoxy (PFA) Teflon tube inside a 12.7-mm-diameter, double-braided, stainless-steel housing was lowered below the surface at each vertical to a depth of $5 \mathrm{~m}$ or one-half the water depth (whichever was smaller) using a 200-pound sounding weight and a second hydraulic winch. Water was pumped up from the fixed depth by a compressedair-driven double-diaphragm, all-PFA Teflon pump (Wilden MI/UP/TF/TF/TF). The volume of river water pumped (see table 8) into a calibrated funnel (45-L, upside-down carboy with no bottom) was proportional to the estimated fractional discharge at each vertical (Moody and Meade, unpub. data, 1992). The water was then processed through the centrifuge and ultrafilter stages described in the "Dewatering of Samples" section.

\section{Suspended-Sediment Size Analysis}

Particle-size distributions of the suspended sediment are listed in tables 15, 16, and 17 . The particle-size distributions of the suspended sands $(>63 \mu \mathrm{m})$ and the suspended silts and clays $(<63 \mu \mathrm{m})$ were analyzed by two different techniques (visual-accumulation tube and Sedigraph), both of which are based on the settling properties of the particles. Both techniques involve preliminary chemical treatment that disaggregates the particles as they exist in the river. Therefore, the size analyses reported here are perhaps more representative of the assemblages of individual particles available to interact with the dissolved matter in the river, and perhaps less representative of the hydraulic properties of the grains as they are transported by the river. Stallard and Martin (1989) described markedly slower settling velocities of suspended sediments chemically dispersed for analysis, such as those reported here, than those allowed to settle immediately after sampling in native river water unaltered by added dispersing agents.

\section{Size Analysis of Suspended Sands}

Suspended sands were separated onsite by pouring the entire suspendedsediment sample, in increments as they were collected, through a 63- $\mu \mathrm{m}$ nickelmesh sieve. The sands that were caught on the sieve were placed in glass jars and transported to the laboratory in Denver, Colorado, where they were dried at about $80^{\circ} \mathrm{C}$ and weighed. After they were weighed, the sand samples were washed into separate polypropylene bottles and taken to the USGS sediment laboratory in Iowa City, Iowa, for size analysis by the visual-accumulationtube method (Guy, 1969).

A difficulty arose during the particle-size analysis of the sand samples when they were given the standard preparation treatment with hydrogen peroxide (Guy, 1969, p. 52) to remove organic matter. This treatment apparently disaggregates sand-size aggregates of silt particles. In most of the suspended-sand samples, the hydrogen peroxide treatment released silt grains from sand-size aggregates in quantities equivalent to concentrations of 1-4 mg/L. These quantities were subtracted from the sand concentrations and added to the concentration of the coarsest silt fraction (31 to $63 \mu \mathrm{m}$ ) in the data reported in tables 15,16 , and 17 , as well as in tables 12,13 , and 14 . 
As an indicator of the reproducibility of the sampling and size-analysis procedures, table 18 shows comparisons of the size analyses of the sand fractions of the $A$ and $B$ composites of 12 suspended-sediment samples. When results were expressed as percentages of the sand fraction, differences between percents finer than certain sizes were as great as 7 percent. When results were expressed as percentages of the total sample, these differences were never more than 2 percent.

\section{Size Analysis of Suspended Silt and Clay}

Samples used in the particle-size analysis of suspended sediment finer than $63 \mu \mathrm{m}$ were aliquots of the depth-integrated composite samples that were collected with the collapsible-bag sampler and passed through the 63- $\mu \mathrm{m}$ sieve. All analyses were made in the USGS sediment laboratory in Iowa City, Iowa, by the Sedigraph method as described by Lara and Matthes (1986).

The essential problem in preparing a suspended-sediment sample for particle-size analysis is one of dewatering--i.e., converting the dilute suspensions collected onsite into the concentrated suspensions required for Sedigraph analysis. This problem was solved in different ways for different samples, as indicated in the fourth column of tables 15, 16, and 17 .

1. A few of the samples collected during the first cruise were filtered onto a sufficient number of membrane filters to provide enough material (about $600 \mathrm{mg}$ ) for analysis. Although the nominal pore size of the membrane filters was $0.45 \mu \mathrm{m}$, the thick cake that accumulated on the filters probably trapped even the finest sizes of particles. This material was redispersed from the membrane filters in an ultrasonic bath to prepare a suspension for Sedigraph analysis.

2. Most of the samples collected during the second cruise, and a few collected during the first cruise, were concentrated by overnight settling. On the day the river-water samples were collected, some 30-40 L of suspensions $<63 \mu \mathrm{m}$ were placed in 45-L carboys and allowed to settle overnight. Next morning, the supernatant water was decanted and the settled sediment was preserved in a glass jar to be transported to the USGS laboratory in Denver. In the laboratory, the settled material was dried, and splits of approximately 1 gram were taken by the cone-and-quarter method. The dried split was sent to the Iowa City laboratory where it was redispersed for Sedigraph analysis. Three samples from the first cruise were prepared by this method as well as by resuspension from filters; a comparison of the results listed in table 15 suggests that the overnight settling recovered slightly less of the finest size fractions than the filtering procedure. Judging from the quantities of material that were recovered by ultrafiltration of the decanted supernatant, the proportion of the sample that was not recovered for particle-size analysis by overnight settling averaged $27( \pm 12)$ percent of the total suspension $<63 \mu \mathrm{m}$ that was collected from the river. Because these proportions of unrecovered material were so large, the particle-size distributions (31 $\mu \mathrm{m}$ and finer) of samples designated "o.s." in the third column of table 16 should not be taken as accurate representations of the suspended sediment transported by the river. The 
analyses of the settled silts are included here only as correlative data for the interpretation of the chemical analyses performed by other project members on splits of the same samples. The particle-size distributions of the sand fractions (63 $\mu \mathrm{m}$ and coarser) probably are accurate because they are based on separate analyses of the sand fractions.

3. One sample, collected from the Mississippi River below Belle Chasse on December 20, 1987 (table 16), was concentrated in the field by the continuous-flow centrifuge (see Leenheer and others, 1989). The drying and splitting procedures in the Denver laboratory were the same as those used on the samples concentrated by overnight settling. Like the samples that were settled overnight, this sample is likely not to have contained the finest 9 percent of the total suspension $<63 \mu \mathrm{m}$ that was collected from the river.

4. By the time of the third cruise, we had settled on the procedure that we have found to be most satisfactory for obtaining and concentrating suspensions of silt and clay for particle-size analysis: In this procedure, the sample remains wet from the time it is collected to the time it is analyzed. Aliquots of 10-20 L of the suspensions $<63 \mu \mathrm{m}$ are collected in the field in polyethylene carboys to which 10-15 mL of chloroform or formaldehyde is added to retard organic growth. The carboys are transported to the USGS laboratory in Denver where the suspended sediment is allowed to settle undisturbed for at least 15 days. At the maximum vertical settling distance of $36 \mathrm{~cm}$ in the carboys, this time is sufficient for all particles coarser than about $0.5 \mu \mathrm{m}$ to settle out (assuming Stokesian settling). After 15 days or longer, the supernatant water is siphoned from the carboys, and the settled sediment is transferred to 1-L glass jars (maximum settling distance, $15 \mathrm{~cm}$ ) where it is allowed to settle for another 10 days or more. The supernatant is siphoned once more, and the settled sediment is transferred to $250-\mathrm{mL}$ polyethylene bottles. After its particle-size distribution has been determined by Sedigraph analysis, the sample is dried and weighed. The dry weight is compared with the weight of sediment that is predicted from the concentration of suspended sediment finer than $63 \mu \mathrm{m}$ determined by the filtering-and-weighing procedure (silt and clay column in table 14) and the known volume of river water from which the analyzed sample was allowed to settle. The differences between the predicted weights and the measured dry weights in the samples analyzed from the third cruise were assumed to represent the quantities of material finer than $0.5 \mu \mathrm{m}$ that remained in suspension and were siphoned from the carboys along with the supernatant water. These differences averaged 16 percent and have been added to the mass of material finer than $1 \mu \mathrm{m}$ for purposes of calculating the percentages listed in table 17 . That is, the percentages listed in table 17 have been corrected to adjust for the quantities of material lost by siphoning. No such corrections have been made in tables 15 and 16 to adjust for the quantities of material lost by decanting or centrifuging. 
Table 15.--particle size, determined by Sedigraph and visual-accumulation (VA) tube, of composite suspended-sediment samples collected from the Mississippi River and its principal tributaries,. July 20 to August 7, 1987. Particle sizes do MOT represent the suspended sediment transported by the river; they represent the particle size of the fraction that was chemically analyzed for trace contaminants. see text for explanation.

[Sedigraph analyses by C.J. Anderson. VA analyses by W.J. Matthes and R.H. Meade. mg/L, ailligrans per liter; $\mu \mathrm{m}$, micrometers; 0.8 . is overnight settling; $\cdots$, no size analysis of less than $63 \mu \mathrm{m}]$

\begin{tabular}{|c|c|c|c|c|c|c|c|c|c|c|c|c|c|c|}
\hline Date & $\begin{array}{l}\text { River } \\
\text { and } \\
\text { section }\end{array}$ & $\begin{array}{l}\text { Total } \\
\text { suspended } \\
\text { concen- } \\
\text { tration } \\
\left(m_{g} / L\right)\end{array}$ & $\begin{array}{l}\text { Treatment } \\
\text { of } \\
\text { fraction } \\
\text { finer } \\
\text { than } \\
63 \mathrm{~mm}\end{array}$ & $T$ & $\frac{\operatorname{Per}}{2}$ & $\frac{\text { ent }}{4}$ & $\frac{\text { finer }}{B}$ & than & $\frac{\text { indic }}{31}$ & $\frac{\text { ated }}{63}$ & $\frac{\text { size, }}{125}$ & $\frac{\text { in } \mu m}{250}$ & 500 & $\begin{array}{c}\text { Median } \\
\text { diameler } \\
(\mu m)\end{array}$ \\
\hline$\frac{1987}{7-20}$ & $\begin{array}{l}\text { Missouri River at } \\
\text { Hermann, Mo. }\end{array}$ & 1,576 & $\begin{array}{l}\text { Filter } \\
0.8 .\end{array}$ & $\begin{array}{l}44 \\
41\end{array}$ & $\begin{array}{l}54 \\
51\end{array}$ & $\begin{array}{l}63 \\
57\end{array}$ & $\begin{array}{l}72 \\
70\end{array}$ & $\begin{array}{l}82 \\
83\end{array}$ & $\begin{array}{l}91 \\
91\end{array}$ & $\begin{array}{l}93 \\
93\end{array}$ & $\begin{array}{l}95 \\
95\end{array}$ & $\begin{array}{l}99 \\
99\end{array}$ & $\begin{array}{l}100 \\
100\end{array}$ & $\begin{array}{l}2 \\
2\end{array}$ \\
\hline $7-23$ & $\begin{array}{l}\text { Mississippi River at } \\
\text { Chester, III. }\end{array}$ & 676 & $\begin{array}{l}\text { Filter } \\
\text { o.s. }\end{array}$ & $\begin{array}{l}52 \\
50\end{array}$ & $\begin{array}{l}60 \\
59\end{array}$ & $\begin{array}{l}68 \\
67\end{array}$ & $\begin{array}{l}76 \\
75\end{array}$ & $\begin{array}{l}86 \\
87\end{array}$ & $\begin{array}{l}94 \\
95\end{array}$ & $\begin{array}{l}97 \\
97\end{array}$ & $\begin{array}{l}98 \\
98\end{array}$ & $\begin{array}{l}100 \\
100\end{array}$ & & 1 \\
\hline $7-28$ & $\begin{array}{l}\text { Mississippi River below } \\
\text { Hickman, Ky. }\end{array}$ & 180 & 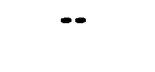 & $\cdots$ & $\cdots$ & -- & -- & -- & $\cdots$ & 98 & 99 & 100 & & -- \\
\hline $7-30$ & $\begin{array}{l}\text { Mississippi River at } \\
\text { Helena, Ark. }\end{array}$ & 282 & - & $\cdots$ & $\cdots$ & $\cdots$ & $\cdots$ & -- & $\cdots$ & 92 & 92 & 97 & 100 & $\cdots$ \\
\hline $8-04$ & $\begin{array}{l}\text { Mississippi River below } \\
\text { Vicksburg, Miss. }\end{array}$ & 224 & -. & - & -- & -- & -- & -. & -- & 96 & 99 & 100 & & - \\
\hline $8-06$ & $\begin{array}{l}\text { 01d River Outflow Channel } \\
\text { near Knox Landing. La. }\end{array}$ & 216 & $\cdots$ & -- & -. & $\cdots$ & $\cdots$ & -. & -- & 94 & 96 & 99 & 100 & -- \\
\hline $8-07$ & $\begin{array}{l}\text { Mississippi River near } \\
\text { St. Francisville, La. }\end{array}$ & 235 & $\cdots$ & -- & -- & - & - & - & -- & 98 & 99 & 100 & & -- \\
\hline
\end{tabular}


Table 16.--Particle size, determined by Sedigraph and visual-accumulation (VA) tube, of couposite suspended-sedinent samples collected from the Mississippi River and its principal tributaries, November 29 to December $20,1987$.

Particle sizes do NOT represent the suspended sediment transported by the river; they represent the particle size of the fraction that was chemically analyzed for trace contaminants.

see text for explanation.

[Sedigraph analyses by C.J. Anderson. VA analyses by W.J. Hatthes and R.H. Heade. g/L, willigrass per liter; $\mathrm{mm}$, micrometers; 0.8 . is overnight settling]

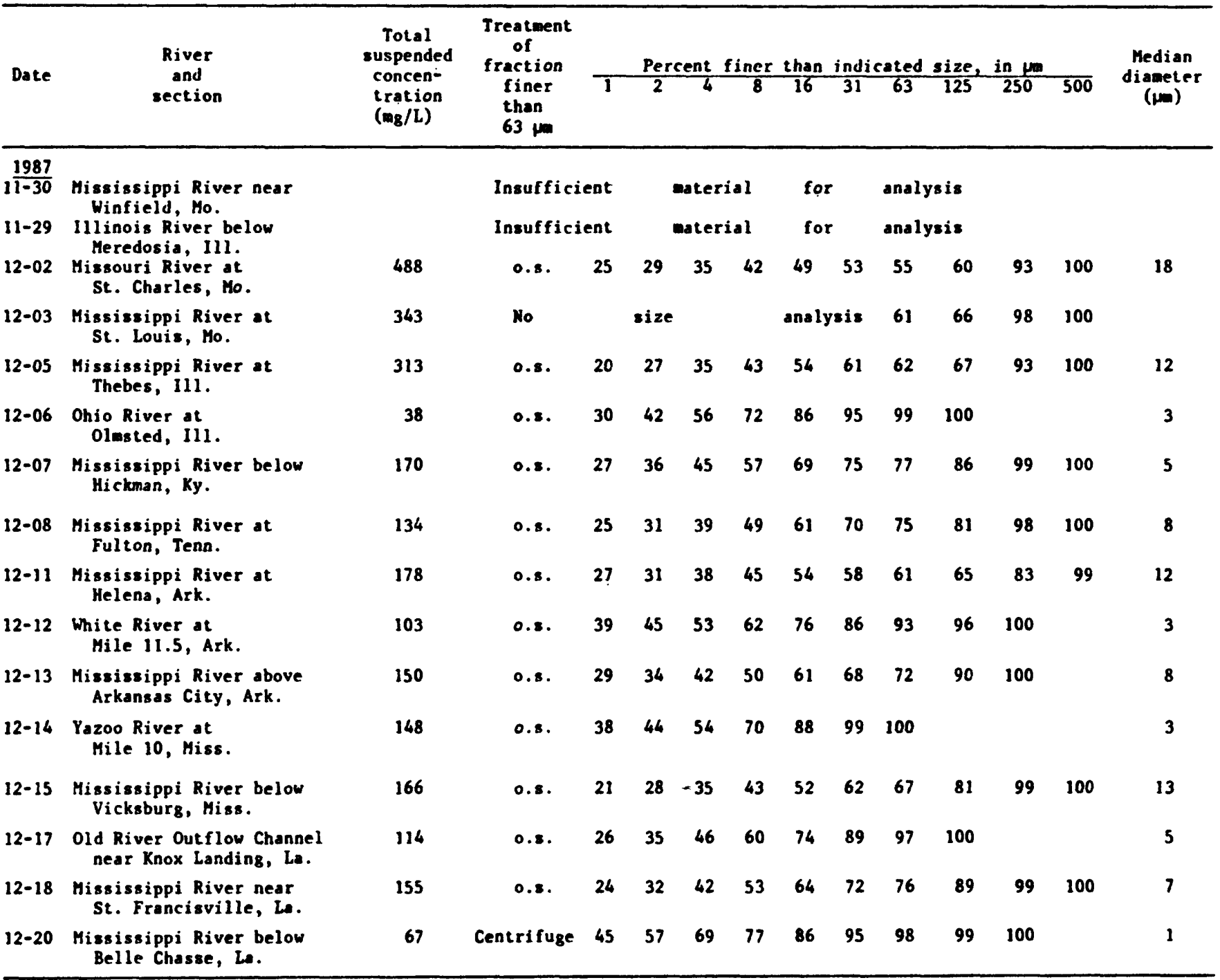


Table 17.--particle size, determined by Sedigraph and visual-accumulation (VA) tube, of composite suspended-sediment samples collectod from the Mississippi River and its principal tributaries, May 16 to June 7, 1988

[Sedigraph analyses by C.J. Anderson; VA analyses by W.J. Matthes and R.H. Heade; g/L, milligrans per liter; $\mu$, micrometers; 1.8 . is long-terw settling]

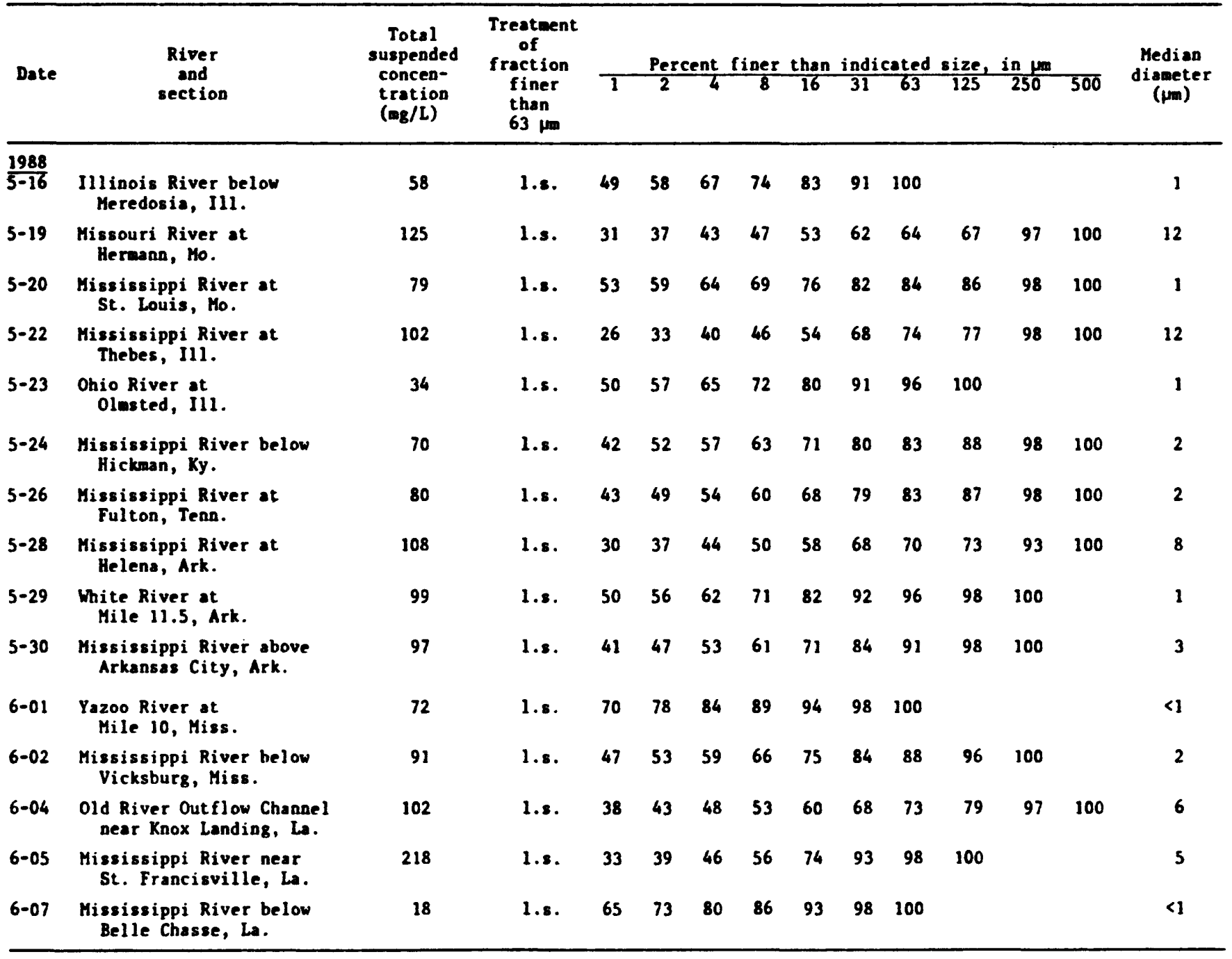


Table 18.--Compariaons of particle-size analyses of sand fractions ( $63 \mu)$ of compsites A and 8 from selected saples

[Visual-accumulation-tube analyses by W.J. Hatthes and R.H. Heade]

\begin{tabular}{|c|c|c|c|c|c|c|c|c|c|c|c|}
\hline River, station, and date & $\begin{array}{l}\text { Con- } \\
\text { pos- } \\
\text { lte }\end{array}$ & $\begin{array}{c}\text { Pex } \\
\text { then }\end{array}$ & $\begin{array}{l}\text { cent of } \\
\text { indicet } \\
125\end{array}$ & $\frac{\text { and }}{\text { ted sta }}$ & $\begin{array}{l}\text { fractio } \\
\text { 2e, in } \\
250\end{array}$ & $\begin{array}{l}\text { on fine } \\
\frac{\text { acrose }}{350}\end{array}$ & $\begin{array}{l}\text { ex } \\
\frac{\text { eters }}{500}\end{array}$ & $\begin{array}{l}\begin{array}{l}\text { Percent of } \\
\text { indicsted }\end{array} \\
63\end{array}$ & $\begin{array}{l}\text { total } \\
\text { size, } \\
125\end{array}$ & $\begin{array}{l}\text { sample finer } \\
\text { in aicromet } \\
250\end{array}$ & $\begin{array}{l}\text { than } \\
\text { ters } \\
300\end{array}$ \\
\hline $\begin{array}{l}\text { Mississippi River at Thebes, I11. } \\
\text { Decenber 5, } 1987\end{array}$ & $\hat{\mathbf{B}}$ & $\begin{array}{l}3 \\
2\end{array}$ & $\begin{array}{l}16 \\
13\end{array}$ & $\begin{array}{l}53 \\
53\end{array}$ & $\begin{array}{l}\mathbf{8 2} \\
\mathbf{8 3}\end{array}$ & $\begin{array}{l}95 \\
96\end{array}$ & $\begin{array}{l}100 \\
99.5\end{array}$ & $\begin{array}{l}63 \\
61\end{array}$ & $\begin{array}{l}68 \\
66\end{array}$ & $\begin{array}{l}93 \\
93\end{array}$ & $\begin{array}{l}100 \\
100\end{array}$ \\
\hline $\begin{array}{l}\text { Mississippi River below Hickma, Ky. } \\
\text { Hay } 24,1988\end{array}$ & $\mathbf{A}$ & $\begin{array}{l}12 \\
13\end{array}$ & $\begin{array}{l}31 \\
34\end{array}$ & $\begin{array}{l}68 \\
68\end{array}$ & $\begin{array}{l}98 \\
99\end{array}$ & $\begin{array}{l}100 \\
100\end{array}$ & & $\begin{array}{l}84 \\
86\end{array}$ & $\begin{array}{l}89 \\
91\end{array}$ & $\begin{array}{l}100 \\
100\end{array}$ & \\
\hline $\begin{array}{l}\text { Mississippi River at heleas, Ark. } \\
\text { July } 30,1987\end{array}$ & $\mathbf{A}$ & 4 & $\begin{array}{r}9 \\
10\end{array}$ & $\begin{array}{l}28 \\
31\end{array}$ & $\begin{array}{l}61 \\
62\end{array}$ & $\begin{array}{l}85 \\
83\end{array}$ & $\begin{array}{r}100 \\
98\end{array}$ & $\begin{array}{l}91 \\
92\end{array}$ & $\begin{array}{l}92 \\
93\end{array}$ & $\begin{array}{l}97 \\
97\end{array}$ & $\begin{array}{l}100 \\
99.8\end{array}$ \\
\hline $\begin{array}{l}\text { White River at Mile 1.1.5, Ark. } \\
\text { December 12, } 1987\end{array}$ & A & $\begin{array}{l}22 \\
20\end{array}$ & $\begin{array}{l}46 \\
45\end{array}$ & $\begin{array}{l}79 \\
78\end{array}$ & $\begin{array}{l}99.5 \\
99.5\end{array}$ & $\begin{array}{l}100 \\
100\end{array}$ & & $\begin{array}{l}96 \\
93\end{array}$ & $\begin{array}{l}96 \\
96\end{array}$ & $\begin{array}{l}100 \\
100\end{array}$ & \\
\hline $\begin{array}{l}\text { White River st Mile } 11.5 \text {, Ark. } \\
\text { Hay 29, } 1988\end{array}$ & $\hat{\mathbf{B}}$ & $\begin{array}{l}21 \\
20\end{array}$ & $\begin{array}{l}60 \\
36\end{array}$ & $\begin{array}{l}67 \\
61\end{array}$ & $\begin{array}{l}99 \\
99\end{array}$ & $\begin{array}{l}100 \\
100\end{array}$ & & $\begin{array}{l}96 \\
96\end{array}$ & $\begin{array}{l}98 \\
98\end{array}$ & $\begin{array}{l}100 \\
100\end{array}$ & \\
\hline $\begin{array}{l}\text { Mississippi River above Arkansas City, Ark. } \\
\text { December 13, } 1987\end{array}$ & $\mathbf{A}$ & $\begin{array}{l}13 \\
16\end{array}$ & $\begin{array}{l}62 \\
65\end{array}$ & $\begin{array}{l}88 \\
88\end{array}$ & $\begin{array}{l}99 \\
99\end{array}$ & $\begin{array}{l}100 \\
100\end{array}$ & & 71 & $\begin{array}{l}89 \\
90\end{array}$ & $\begin{array}{l}100 \\
100\end{array}$ & \\
\hline $\begin{array}{l}\text { Mississippi River soove Arkansas City, Ark. } \\
\text { Hay 30, } 1988\end{array}$ & $\mathbf{A}$ & $\begin{array}{l}31 \\
28\end{array}$ & $\begin{array}{l}72 \\
65\end{array}$ & $\begin{array}{l}93 \\
86\end{array}$ & $\begin{array}{c}100 \\
99.5\end{array}$ & 100 & & $\begin{array}{l}91 \\
89\end{array}$ & $\begin{array}{l}97 \\
96\end{array}$ & $\begin{array}{l}100 \\
100\end{array}$ & \\
\hline $\begin{array}{l}\text { Mississippi River below Vicksburs, Miss. } \\
\text { August 4, } 1987\end{array}$ & $\begin{array}{l}\mathbf{A} \\
\mathbf{B}\end{array}$ & $\begin{array}{l}32 \\
35\end{array}$ & $\begin{array}{l}62 \\
68\end{array}$ & $\begin{array}{l}88 \\
91\end{array}$ & $\begin{array}{l}98 \\
99\end{array}$ & $\begin{array}{l}100 \\
99.3\end{array}$ & 99.5 & $\begin{array}{l}96 \\
96\end{array}$ & $\begin{array}{l}99 \\
99\end{array}$ & $\begin{array}{l}100 \\
100\end{array}$ & \\
\hline $\begin{array}{l}\text { Old River Outflow Channel near Knox Landing, La. } \\
\text { August 6, } 1987\end{array}$ & $\hat{\mathbf{B}}$ & $\begin{array}{l}12 \\
12\end{array}$ & $\begin{array}{l}26 \\
26\end{array}$ & $\begin{array}{l}62 \\
63\end{array}$ & $\begin{array}{l}89 \\
92\end{array}$ & $\begin{array}{l}100 \\
100\end{array}$ & & $\begin{array}{l}94 \\
94\end{array}$ & $\begin{array}{l}96 \\
96\end{array}$ & $\begin{array}{l}99 \\
99\end{array}$ & $\begin{array}{l}100 \\
100\end{array}$ \\
\hline $\begin{array}{l}\text { Old River Outflow Channel near Knox Landing, La. } \\
\text { December } 17,1987\end{array}$ & $\begin{array}{l}\mathbf{A} \\
\mathbf{B}\end{array}$ & $\begin{array}{l}82 \\
82\end{array}$ & $\begin{array}{r}100 \\
98\end{array}$ & 100 & & & & $\begin{array}{l}97 \\
97\end{array}$ & $\begin{array}{l}100 \\
100\end{array}$ & & \\
\hline $\begin{array}{l}\text { Mississippi River near St. Francisville, Le. } \\
\text { August 7, } 1987\end{array}$ & $\mathbf{A}$ & $\begin{array}{l}61 \\
43\end{array}$ & $\begin{array}{l}65 \\
68\end{array}$ & $\begin{array}{l}90 \\
86\end{array}$ & $\begin{array}{r}100 \\
97\end{array}$ & 100 & & $\begin{array}{l}98 \\
98\end{array}$ & $\begin{array}{l}99 \\
99\end{array}$ & $\begin{array}{l}100 \\
100\end{array}$ & \\
\hline $\begin{array}{l}\text { Mississippi River near St. Francisville, L. } \\
\text { June 5, } 1988\end{array}$ & $\mathbf{A}$ & $\begin{array}{l}58 \\
50\end{array}$ & $\begin{array}{l}83 \\
80\end{array}$ & $\begin{array}{l}98 \\
98\end{array}$ & $\begin{array}{l}100 \\
100\end{array}$ & & & $\begin{array}{l}98 \\
98\end{array}$ & $\begin{array}{l}99 \\
99\end{array}$ & $\begin{array}{l}100 \\
100\end{array}$ & \\
\hline
\end{tabular}




\section{SURFACE-WATER PROPERTIES}

At each vertical in the cross section (for the November-December 1987 and May-June 1988 cruises) a surface-water sample was collected with a bucket and the temperature, $\mathrm{pH}$, and conductivity were measured (see "Tabulated Cruise Data" section). Temperatures and $\mathrm{pH}$ were measured with a Beckman $\mathrm{pH}$ meter (model $\phi 12$ ) and the conductivity was measured with an Amberscience conductivity meter (model 640). Both meters were calibrated with standards. During the May-June 1988 cruise, two $200-\mathrm{mL}$ samples from each cross section were collected and the conductivity was measured with a salinometer (Guildine Autosal 8400). Thirty-four samples had an average difference of less than $1 \mathrm{microsiemen} / \mathrm{cm}$ and a range of difference from -21 to $15 \mathrm{microsiemens} / \mathrm{cm}$.

\section{DEWATERING OF SAMPLES}

Settling, centrifugation, and ultrafiltration were used to remove the particles finer than $63 \mu \mathrm{m}$ from the water samples. The combination of these methods that was used on each cruise is described below. A generalized flow diagram for the processing stages of dewatering the samples is shown in figure 10 .

\section{July-August 1987 Cruise}

The combined A and B composites were allowed to settle in a glass carboy overnight on land to concentrate the silt and clay fraction ( $<63 \mu \mathrm{m})$. The vertical settling distance was approximately 40 to $50 \mathrm{~cm}$, and, after settling, the water containing the colloid fraction $(<3 \mu \mathrm{m})$ was siphoned from the glass carboy into a second carboy. The remaining silt/clay slurry was later centrifuged in a laboratory at 5,000 revolutions per minute (r.p.m.) for 30 minutes and then freeze dried. The mass of silt material recovered at each site for the first cruise is listed in table 19. The water containing the colloid fraction was pumped through a tangential-flow ultrafiltration unit (DorrOliver, Series L) consisting of 15 flat plates supporting heat-sealed, regenerated, cellulose membranes with a pore size of about $0.005 \mu \mathrm{m}$ [see Leenheer and others (1989) for specifications and testing of ultrafilter components]. The ultrafilter unit was disassembled and the colloid fraction was rubbed from the membranes, which were held in Teflon bags with a minimal volume of water that had not passed through the membrane. This concentrated colloid slurry was centrifuged at $8,000 \mathrm{r.p} . \mathrm{m}$. for 30 minutes and then freeze dried. The mass of colloidal material recovered at each site for the first cruise is listed in table 19. Dissolved organics (Leenheer and others, 1989) were extracted from the ultrafilter permeate by adsorption chromatography on Amberlite $X A D-8$ resin, and about $20 \mathrm{~L}$ of the permeate was saved for radioactive chemical analysis. 


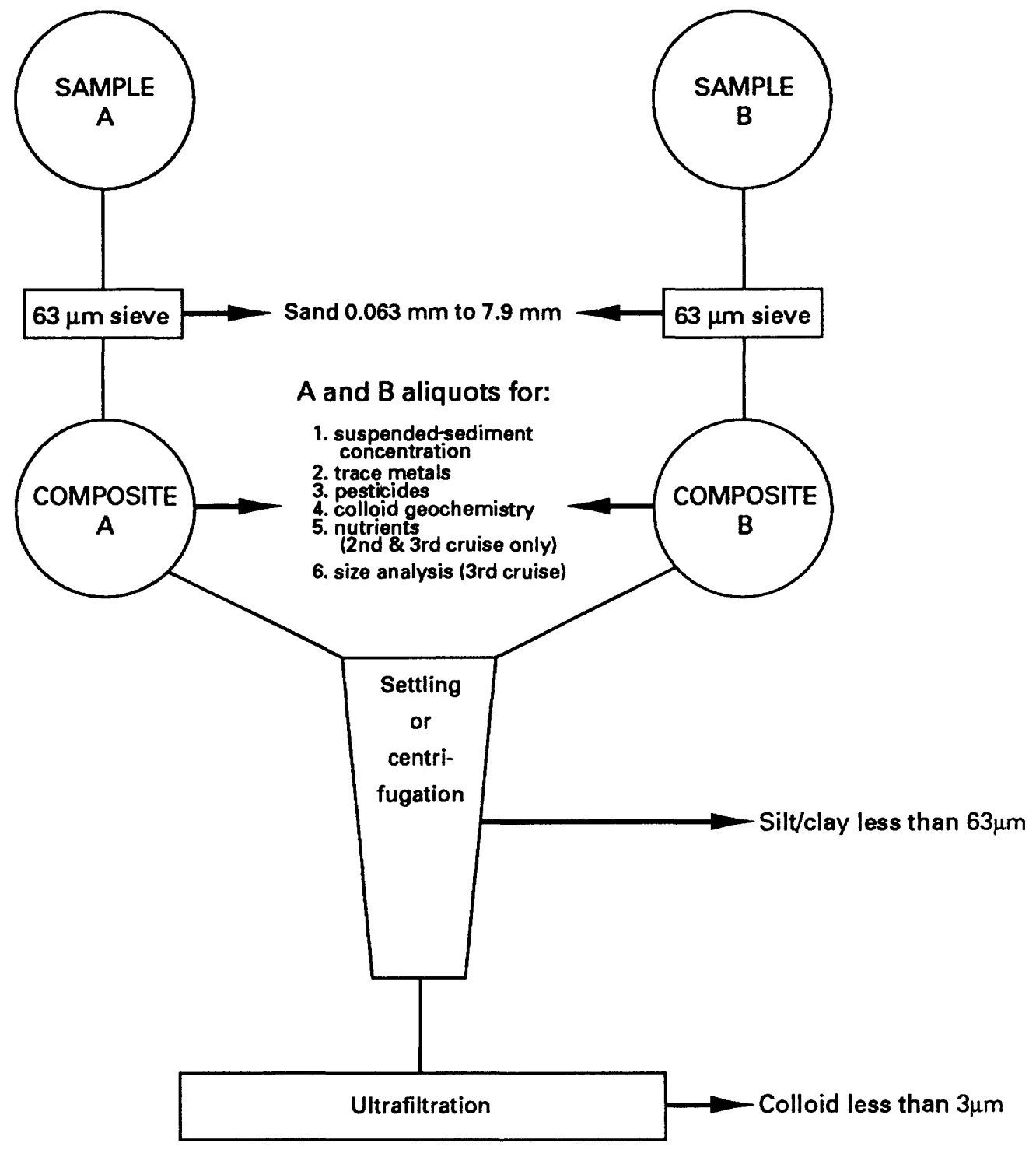

Figure 10.--Flow diagram for processing the suspended-sediment samples collected by depth integration. 
Table 19.--Water volume processed and ass of silt/clay and colloidal material recovered from samples of the nississippi River and its principal tributaries botween July 18 - August 9,1987

[Analyses by T.I. Brinton, P. Brown, T.I. Noyes, and R.H. Meade]

\begin{tabular}{|c|c|c|c|c|c|c|c|}
\hline \multirow[b]{2}{*}{ Date } & \multirow[b]{2}{*}{ River and section } & \multirow[b]{2}{*}{$\begin{array}{l}\text { Water } \\
\text { volume } \\
\text { processed } \\
\text { (l) }\end{array}$} & \multicolumn{3}{|c|}{ Mass recovered } & \multirow{2}{*}{$\begin{array}{l}\text { Total } \\
\text { suspended } \\
\text { sediment } \\
<63 \mathrm{~m}^{3} \\
(\mathrm{~g})\end{array}$} & \multirow[b]{2}{*}{$\begin{array}{l}\text { Percent } \\
\text { recovery }\end{array}$} \\
\hline & & & $\begin{array}{l}\text { Silt/ } \\
\text { clay } \\
(8)\end{array}$ & $\begin{array}{l}\text { Colloid } \\
(8)\end{array}$ & $\begin{array}{l}\text { Silt/ } \\
\text { clay + } \\
\text { colloid } \\
\quad(8)\end{array}$ & & \\
\hline $\begin{array}{l}\frac{1987}{7-19} \\
7-18 \\
7-21 \\
7-20 \\
7-22\end{array}$ & $\begin{array}{l}\text { Mississippi R. near Winfield, Mo. } \\
\text { Illinois R. at Naples, Ill. } \\
\text { Mississippi R. at Hartford, Ill. } \\
\text { Missouri R. at Hermann, Mo. } \\
\text { Mississippi R. at St. Louis, Mo. }\end{array}$ & $\begin{array}{l}92.0 \\
92.0 \\
93.2 \\
58.4 \\
85.4\end{array}$ & $\begin{array}{l}0.92 \\
3.46 \\
1.75 \\
72.5 \\
46.5\end{array}$ & $\begin{array}{l}3.45 \\
3.83 \\
1.57 \\
6.12 \\
6.43\end{array}$ & $\begin{array}{r}4.37 \\
7.29 \\
3.32 \\
78.62 \\
52.93\end{array}$ & $\begin{array}{r}-- \\
3.91 \\
85.59 \\
56.44\end{array}$ & $\begin{array}{l}-- \\
05 \\
92 \\
94\end{array}$ \\
\hline $\begin{array}{l}7-23 \\
7-26 \\
7-27 \\
7-28 \\
7-30\end{array}$ & $\begin{array}{l}\text { Mississippi R. at Chester, Mo. } \\
\text { Ohio R. below Smithland Locks and Dam, Ill.-Ky. } \\
\text { Ohio R. at Olmsted, Ill. } \\
\text { Mississippi R. below Hickan, Ky. } \\
\text { Mississippi R. ot Helena, Ark. }\end{array}$ & $\begin{array}{r}65.3 \\
86.0 \\
82.0 \\
81.4 \\
104.5\end{array}$ & $\begin{array}{r}33.5 \\
0.80 \\
0.95 \\
10.39 \\
19.57\end{array}$ & $\begin{array}{l}5.63 \\
0.63 \\
0.48 \\
2.07 \\
4.72\end{array}$ & $\begin{array}{r}39.13 \\
1.43 \\
1.43 \\
12.46 \\
24.29\end{array}$ & $\begin{array}{r}42.67 \\
1.89 \\
2.01 \\
14.40 \\
27.01\end{array}$ & $\begin{array}{l}92 \\
76 \\
71 \\
87 \\
90\end{array}$ \\
\hline $\begin{array}{l}7-31 \\
8-01 \\
8-02 \\
8-04 \\
8-06\end{array}$ & $\begin{array}{l}\text { White R. at Mile } 11: 5 \text {, Ark. } \\
\text { Arkansas R. at Mile } 55.9 \text {, Ark. } \\
\text { Mississippi R. above Arkansas City, Ark. } \\
\text { Mississippi R. below Vicksbur8, Miss. } \\
\text { Old R. Outflow Channel near Knox Landing, La. }\end{array}$ & $\begin{array}{r}96.7 \\
87.4 \\
84.0 \\
47.8 \\
85.4\end{array}$ & $\begin{array}{r}8.53 \\
1.19 \\
15.16 \\
10.14 \\
11.04\end{array}$ & $\begin{array}{r}1.10 \\
0.41 \\
3.74 \\
2.01 \\
3.99\end{array}$ & $\begin{array}{r}9.63 \\
1.60 \\
18.90 \\
12.15 \\
15.03\end{array}$ & $\begin{array}{r}11.80 \\
2.01 \\
22.39 \\
16.77 \\
17.38\end{array}$ & $\begin{array}{r}82 \\
80 \\
84 \\
472 \\
86\end{array}$ \\
\hline $\begin{array}{l}8-07 \\
8-09\end{array}$ & $\begin{array}{l}\text { Mississippi R. near St. Francisville, La. } \\
\text { Mississippi R. below Belle Chasse, La. }\end{array}$ & $\begin{array}{l}78.4 \\
86.2\end{array}$ & $\begin{array}{r}13.45 \\
2.58\end{array}$ & $\begin{array}{l}2.92 \\
2.17\end{array}$ & $\begin{array}{r}16.37 \\
4.75\end{array}$ & $\begin{array}{r}18.03 \\
5.69\end{array}$ & $\begin{array}{l}91 \\
83\end{array}$ \\
\hline
\end{tabular}

'Haterial which settled a vertical distance of approximately $40-50 \mathrm{~cm}$ overnight in a glass carboy.

Material which was decanted from the settling carboy and collected on ultrafilter menbranes (0.005-him pore size).

${ }^{3}$ Suspended-sediment concentration (average of composite A and B in table 12 for <63- mmaterial) times water volume processed.

Approximately $40 \mathrm{~L}$ was lost when a carboy broke.

\section{November-December 1987 Cruise}

Two dewatering methods were used to remove the silt and clay. A gimbal stand was constructed to hold the glass carboy and reduce the agitation from ship motion. One-half of the composite sample was settled overnight (settling distance 40-50 cm for 8-12 hours) aboard the research ship while it was moored to a dock, and the other one-half was centrifuged aboard the ship. The supernatant and centrifuge effluent were saved. The centrifuge [Sharples, Model AS-12; see Leenheer and others (1989) for more details] was operated at about 15,000 r.p.m. with a flow rate of about $2 \mathrm{~L} / \mathrm{min}$. The resulting settled and centrifuged silt slurries were later centrifuged in the laboratory ashore and freeze dried. The masses of settled and centrifuged silt recovered are listed in table 20. The supernatant from the settling process and the centrifuge effluent were separately pumped through the ultrafilter unit, which had only three regenerated, cellulose membranes. The colloid fraction removed from the membranes was centrifuged later at 5,000 r.p.m. for 20 minutes (except Yazoo River sample, which was centrifuged at 18,000 r.p.m. for 30 minutes) and freeze dried. The masses of settled and centrifuged colloids recovered are listed in table 20. Dissolved organics (Leenheer and others, 1989) were extracted from the ultrafilter permeate and about $20 \mathrm{~L}$ of the permeate was saved for radioactive chemical analysis (Mississippi River at St. Louis, below Hickman, below Vicksburg, and below Belle Chasse). 
Table 20.--Water volume processed and ass of silt/clay and colloidal anterial recovered from samples of the nississippi River and its principal tributaries botween November 29 - December 20 , 1987

[Analyses by T.I. Brinton, P. Brown, T.I. Noyes, and R.H. Meade]

\begin{tabular}{|c|c|c|c|c|c|c|c|c|}
\hline \multirow[b]{2}{*}{ Date } & \multirow[b]{2}{*}{ River and section } & \multirow[b]{2}{*}{$\begin{array}{l}\text { Collection } \\
\text { method }\end{array}$} & \multirow[b]{2}{*}{$\begin{array}{l}\text { Water } \\
\text { volune } \\
\text { processed } \\
\text { (L) }\end{array}$} & \multicolumn{3}{|c|}{ Mass recovered } & \multirow{2}{*}{$\begin{array}{l}\text { Total } \\
\text { suspended } \\
\text { sediment } \\
<63 \mathrm{~mm}^{3} \\
\text { (8) }\end{array}$} & \multirow[b]{2}{*}{$\begin{array}{l}\text { Percent } \\
\text { recovery }\end{array}$} \\
\hline & & & & $\begin{array}{l}\text { silt/ } \\
\text { clay } \\
(\mathrm{g})\end{array}$ & $\begin{array}{c}\text { Colloid } \\
(\mathrm{g})\end{array}$ & $\begin{array}{l}\text { Silt/ } \\
\text { clay }+ \\
\text { colloid } \\
(8)\end{array}$ & & \\
\hline $\begin{array}{l}\frac{1987}{11-30} \\
11-29\end{array}$ & $\begin{array}{l}\text { Mississippi R. near } \\
\text { Winfield, Mo. } \\
\text { Illinois R. below } \\
\text { Meredosia, Ill. }\end{array}$ & $\begin{array}{l}\text { settled } \\
\text { settled }\end{array}$ & $\begin{array}{l}85.8 \\
89.0\end{array}$ & $\begin{array}{l}1.16 \\
2.66\end{array}$ & $\begin{array}{l}0.53 \\
1.05\end{array}$ & $\begin{array}{l}1.69 \\
3.71\end{array}$ & $\begin{array}{l}2.62 \\
7.03\end{array}$ & $53^{\circ}$ \\
\hline $\begin{array}{l}12-02 \\
12-03\end{array}$ & $\begin{array}{l}\text { Missouri R. at } \\
\text { St. Charles, Mo. } \\
\text { Mississippi R. at } \\
\text { St. Louis, Mo. }\end{array}$ & $\begin{array}{l}\text { settled } \\
\text { centrifuged } \\
\text { settled } \\
\text { centrifuged }\end{array}$ & $\begin{array}{l}47.3 \\
43.4 \\
44.8 \\
53.7\end{array}$ & $\begin{array}{l}8.16 \\
6.61 \\
15.47 \\
\text { combined }\end{array}$ & $\begin{array}{l}1.71 \\
0.33 \\
2.15\end{array}$ & $\begin{array}{l}9.87 \\
6.94 \\
17.62 \\
\text { with }\end{array}$ & $\begin{array}{l}12.63 \\
11.61 \\
20.60\end{array}$ & $\begin{array}{c}78 \\
60 \\
86 \\
\text { settled }\end{array}$ \\
\hline $\begin{array}{l}12-05 \\
12-06 \\
12-07 \\
12-08\end{array}$ & $\begin{array}{l}\text { Mississippi R. at } \\
\text { Thebes, III. } \\
\text { Ohio R. at } \\
\text { Olasted, III. } \\
\text { Mississippi R. below } \\
\text { Hicksan, Ky. } \\
\text { Mississippi R. at } \\
\text { Fulton, Tenn. }\end{array}$ & $\begin{array}{l}\text { settled } \\
\text { centrifuged } \\
\text { settled } \\
\text { centrifuged } \\
\text { settled } \\
\text { centrifuged } \\
\text { settled } \\
\text { centrifuged }\end{array}$ & $\begin{array}{l}38.5 \\
39.8 \\
50.4 \\
59.1 \\
43.5 \\
44.1 \\
45.7 \\
43.6\end{array}$ & $\begin{array}{l}5.11 \\
5.75 \\
0.98 \\
1.89 \\
3.35 \\
4.18 \\
3.09 \\
3.00\end{array}$ & $\begin{array}{l}1.25 \\
0.59 \\
0.54 \\
0.14 \\
1.12 \\
0.50 \\
1.00 \\
0.35\end{array}$ & $\begin{array}{l}6.36 \\
6.34 \\
1.52 \\
2.03 \\
4.47 \\
4.68 \\
4.09 \\
3.35\end{array}$ & $\begin{array}{l}7.47 \\
7.72 \\
1.86 \\
2.19 \\
5.70 \\
5.78 \\
4.52 \\
4.32\end{array}$ & $\begin{array}{l}85 \\
82 \\
82 \\
93 \\
78 \\
81 \\
90 \\
78\end{array}$ \\
\hline $\begin{array}{l}12-11 \\
12-12 \\
12-13 \\
12-14\end{array}$ & $\begin{array}{l}\text { Mississippi R. at } \\
\text { Helena, Ark. } \\
\text { White R. at } \\
\text { Mile il.5, Ark. } \\
\text { Mississippi R. above } \\
\text { Arkansas City, Ark. } \\
\text { Yazoo R. at } \\
\text { Mile io, Miss. }\end{array}$ & $\begin{array}{l}\text { settled } \\
\text { centrifuged } \\
\text { settled } \\
\text { centrifuged } \\
\text { settled } \\
\text { centrifuged } \\
\text { settled } \\
\text { centrifuged }\end{array}$ & $\begin{array}{l}42.6 \\
40.9 \\
46.0 \\
59.6 \\
40.3 \\
38.7 \\
42.1 \\
33.7\end{array}$ & $\begin{array}{l}2.86 \\
3.18 \\
2.08 \\
3.20 \\
2.44 \\
2.47 \\
2.34 \\
2.55\end{array}$ & $\begin{array}{l}1.06 \\
0.38 \\
1.65 \\
1.03 \\
1.17 \\
0.35 \\
2.98 \\
1.40\end{array}$ & $\begin{array}{l}3.92 \\
3.56 \\
3.73 \\
4.23 \\
3.61 \\
2.82 \\
5.32 \\
3.95\end{array}$ & $\begin{array}{l}4.56 \\
4.38 \\
4.41 \\
5.72 \\
4.31 \\
4.14 \\
6.23 \\
4.99\end{array}$ & $\begin{array}{l}86 \\
81 \\
85 \\
74 \\
84 \\
68 \\
85 \\
79\end{array}$ \\
\hline $\begin{array}{l}12-15 \\
12-17 \\
12-18 \\
12-20\end{array}$ & $\begin{array}{l}\text { Mississippi R. below } \\
\text { Vicksburg, Hiss. } \\
\text { Old R. Outflow Channel } \\
\text { near Knox Landing, La. } \\
\text { Mississippi R. near } \\
\text { St. Francisville, La. } \\
\text { Mississippi R. below } \\
\text { Belle Chasse, La. }\end{array}$ & $\begin{array}{l}\text { settled } \\
\text { centrifuged } \\
\text { settled } \\
\text { centrifuged } \\
\text { settled } \\
\text { centrifuged } \\
\text { centrifuged }\end{array}$ & $\begin{array}{l}35.7 \\
40.3 \\
44.0 \\
49.1 \\
46.0 \\
55.8 \\
92.9\end{array}$ & $\begin{array}{l}2.09 \\
2.34 \\
2.94 \\
3.69 \\
3.07 \\
4.02 \\
4.41\end{array}$ & $\begin{array}{l}0.97 \\
0.18 \\
1.23 \\
0.25 \\
1.15 \\
0.20 \\
0.56\end{array}$ & $\begin{array}{l}3.06 \\
2.52 \\
4.17 \\
3.94 \\
4.22 \\
4.22 \\
4.97\end{array}$ & $\begin{array}{l}4.00 \\
4.51 \\
4.84 \\
5.40 \\
5.42 \\
6.58 \\
6.13\end{array}$ & $\begin{array}{l}77 \\
56 \\
86 \\
73 \\
78 \\
64 \\
81\end{array}$ \\
\hline
\end{tabular}

'Material which was settled a vertical distance of approximately $40-50 \mathrm{~cm}$ for 8-12 hours in a glass carboy held in a gimballed stand onboard the ship moored to a dock, or material which was collected in a centrifuge bowl (approximate radius is $5.6 \mathrm{~cm}$ and length is $60 \mathrm{~cm}$ ) operating at about $15,000 \mathrm{r} . \mathrm{p}$.m. with a flow rate of about $2 \mathrm{~L} / \mathrm{min}$.

${ }^{2}$ Material which was collected on ultrafilter membranes $(0.005-\mu m$ pore size) after settling or centrifugation.

${ }^{3}$ Suspended-sediment concentration (average of composite $A$ and $B$ in table 13 for $<63 \mu m$ ) times the water volume processed.

\section{May-June 1988 Cruise}

Only the centrifuge was used to remove the silt/clay fractions during this cruise. The centrifuge was operated between 15,000-16,000 r.p.m. with a flow rate of $2 \mathrm{~L} / \mathrm{min}$. The centrifuge effluent was pumped through the ultrafiltration unit; the collected retentate was centrifuged later at $12,000 \mathrm{r} . \mathrm{p} . \mathrm{m}$. for 30 minutes and then freeze dried. The masses of silt/clay and of the colloid fractions recovered are listed in table 21 . Part of the ultrafilter permeate was saved for dissolved organic analysis $(20 \mathrm{~L})$ and radioactive chemical analysis ( $20 \mathrm{~L}$ from the same sections as the NovemberDecember 1987 cruise). 
Table 21.--Water volumes processed and mass of silt/clay, colloid, and ultraretentate recovered fron samples of the Mississippi River and its principal tributaries between May 16 - June 7, 1988

IInteg. or pump indicates that samples were collected by depth-integration or pumping method. Only the silt/clay mass was recovered from the samples collected by the pumping method. Analysis by T.I. Brinton, P. Brown, T.I. Noyes, and R.H. Meade]

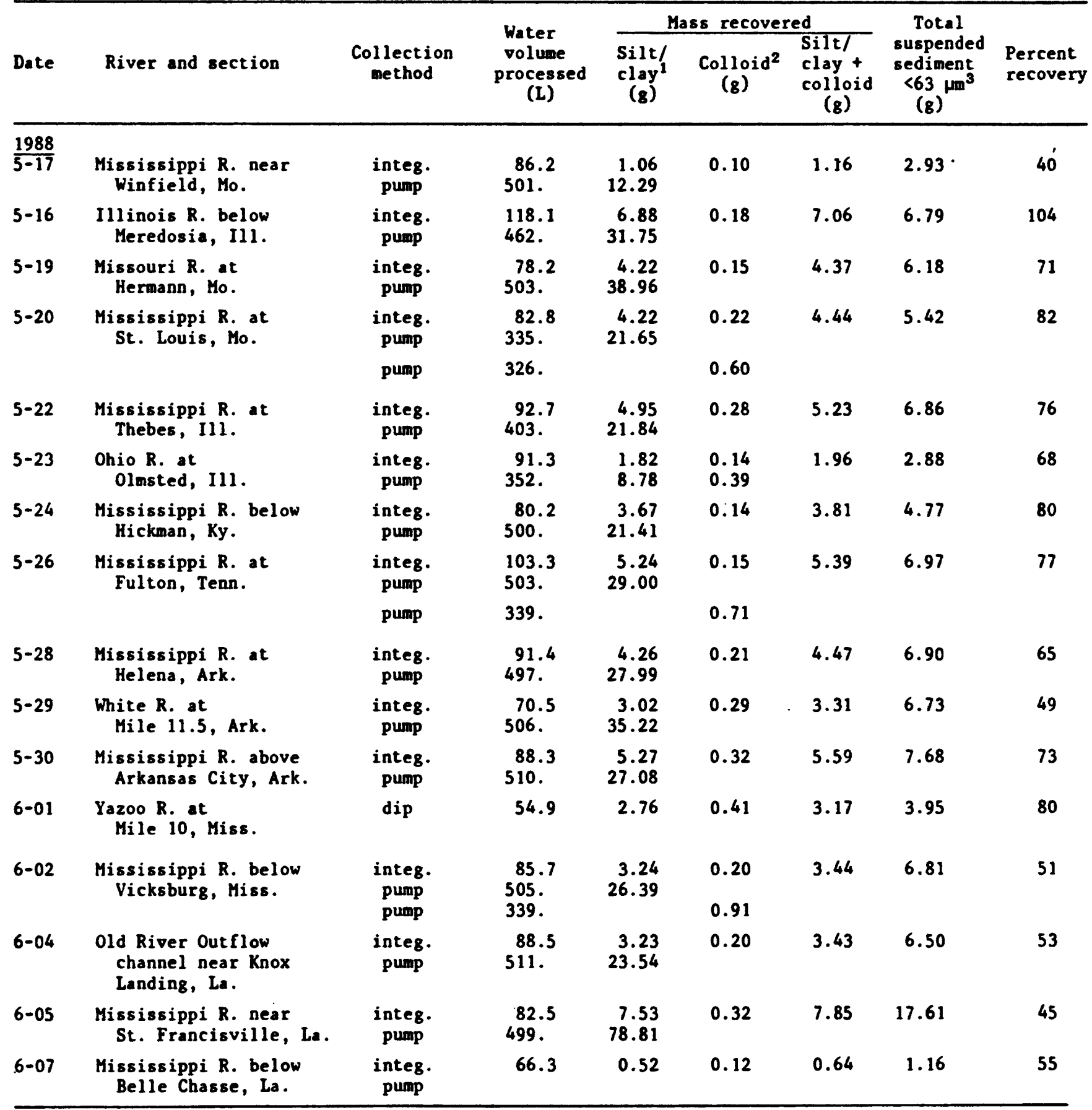

${ }^{1}$ Material recovered from a centrifuge bowl (approximate radius is $5.6 \mathrm{~cm}$ and $1 \mathrm{ength}$ is $60 \mathrm{~cm}$ ) operating at about $15,000 \mathrm{r.p} . \mathrm{m}$. with a flow rate of about $2 \mathrm{~L} / \mathrm{min}$.

${ }^{2}$ Material recovered from ultrafilter membranes (0.005- $\mu$ m pore size) after passing through the centrifuge.

${ }^{3}$ Suspended-sediment concentration (average of composite A and B in table 14 for <63- $\mu m$ material) times the water volume processed. 


\section{NEAR BOTTOM CURRENT MEASUREMENTS}

During the second cruise (November 29 to December 20, 1988), an oceanographic vector averaging current meter (EG\&G, Model 610) and temperature/ pressure recorder [Pacer (formerly Sea Data), Model TDR-2A] were deployed at seven river sites (table 22) for 4 to 16 hours. A tripod held the current meter 1.8 meters above the bottom and the temperature/pressure recorder 1.0 meter above the bottom. A data logger recorded an average measurement of current speed and water temperature every 28.125 seconds. The minimum and maximum current speed and temperature for the length of the record are listed in table 22. The mean current speed (table 22) was usually less than the mean current speed for the cross section (table 10) since the instruments were not deployed in the main river navigation channel.

Table 22.--Doployment locations of a moored vector averaging current meter in seven rivers and statistics of current speed and temperature

[The current weter was 1.8 meters above the botton and the temperature sensor was about 1 meter above the botton. $A$ measurement of speed and di rection was recorded after a 28.125 -second averaging interval. Start and stop limes are Greenwich mean time where $y=$ year, $\min =$ month, dd $=$ day, hh $=$ hour, and w $=$ minutes]

\begin{tabular}{|c|c|c|c|c|c|c|c|c|c|c|}
\hline \multirow[b]{2}{*}{ Date } & \multirow[b]{2}{*}{ River and section } & \multicolumn{2}{|c|}{ Time } & \multirow{2}{*}{$\begin{array}{l}\text { Length } \\
\text { of } \\
\text { record } \\
\text { (hours) }\end{array}$} & \multirow{2}{*}{$\begin{array}{c}\text { Water } \\
\text { depth } \\
\text { (neters) }\end{array}$} & \multicolumn{3}{|c|}{ Current speed } & \multicolumn{2}{|c|}{${ }^{1}$ Temperature } \\
\hline & & $\begin{array}{c}\text { Start } \\
\text { (yymaddhham) }\end{array}$ & $\begin{array}{c}\text { Stop } \\
\text { (yymanddhhom) }\end{array}$ & & & $\underset{(\mathrm{cm} / \mathrm{s})}{\min .}$ & $\begin{array}{l}\max \\
(\mathrm{cm} / \mathrm{s})\end{array}$ & $\begin{array}{c}\text { mean } \\
(\mathrm{cm} / \mathrm{s})\end{array}$ & $\left.{ }^{\circ}{ }^{\circ} \mathrm{C}\right)$ & $\begin{array}{l}\max . \\
\left({ }^{\circ} \mathrm{C}\right)\end{array}$ \\
\hline $11-30$ & $\begin{array}{l}\text { Mississippi R. near } \\
\text { Winfield, Mo. }\end{array}$ & 8711301602 & 8711302306 & 7.13 & 5.0 & 38.0 & 59.5 & 50.2 & 3.9 & 5.3 \\
\hline $11-29$ & $\begin{array}{l}\text { Illinois R. below } \\
\text { Meredosis, Ill. }\end{array}$ & 8711291641 & 8711292045 & 4.14 & 6.6 & 12.1 & 39.5 & 20.4 & 5.8 & 5.9 \\
\hline $12-02$ & $\begin{array}{l}\text { Missouri R. at } \\
\text { St. Charles, Mo. }\end{array}$ & 8712020024 & 8712021147 & 11.44 & 4.2 & 53.5 & 99.0 & 79.3 & 5.3 & 6.6 \\
\hline $12-06$ & $\begin{array}{l}\text { Ohio R. at } \\
\text { Olmsted, } 111 \text {. }\end{array}$ & 8712061440 & 8712062202 & 7.41 & 5.2 & 38.2 & 51.8 & 44.7 & 7.2 & 9.1 \\
\hline $12-12$ & $\begin{array}{l}\text { White R. } \\
\text { Mile 11.5, Ark. }\end{array}$ & 8712121447 & 8712122315 & 8.51 & 3.6 & 57.2 & 92.9 & 79.6 & 8.4 & 10.3 \\
\hline $12-14$ & $\begin{array}{l}\text { Yazoo R. at } \\
\text { Vicksburg Landing, Miss. }\end{array}$ & 8712152335 & 8712161526 & 15.93 & 5.6 & 11.5 & 29.6 & 18.6 & 9.5 & 11.9 \\
\hline $12-17$ & $\begin{array}{l}\text { Old } R \text {. Outflow Channel near } \\
\text { Knox Landing, La. }\end{array}$ & 8712171353 & 8712172320 & 9.50 & 4.8 & 41.8 & 70.1 & 59.3 & 4.3 & 8.9 \\
\hline
\end{tabular}

${ }^{1}$ The temperature values were averaged over eight intervals of 28.125 seconds to ohtain the above 225-second average.

\section{SURFACE-WATER TRAVEL-TIME MEASUREMENTS}

During the third cruise (May 16 to June 7, 1988), 5,000 drift cards were released on the river surface to measure the surface-water travel time between sampling sites. The drift card consisted of a business reply postcard with a piece of fluorescent orange paper sealed inside a $12-\mathrm{cm}$ by $20-\mathrm{cm}$ clear plastic bag. The postcards were numbered sequentially from 1 to 5,000 and on one side there were blank spaces for the location and time of recovery to be recorded by the finder. Out of the 5,000 cards released, 41 were found floating and provided measurements of surface-water travel time, and 149 were recovered onshore. Minimum, maximum, and mean surface-water speeds are listed in table 23. The farthest distance traveled by a drift card was $311 \mathrm{~km}$ at a mean speed of $0.94 \mathrm{~m} / \mathrm{s}$. The travel times (see table 24) for river reaches between sampling cross sections have been computed using the limited data set in table 23. 


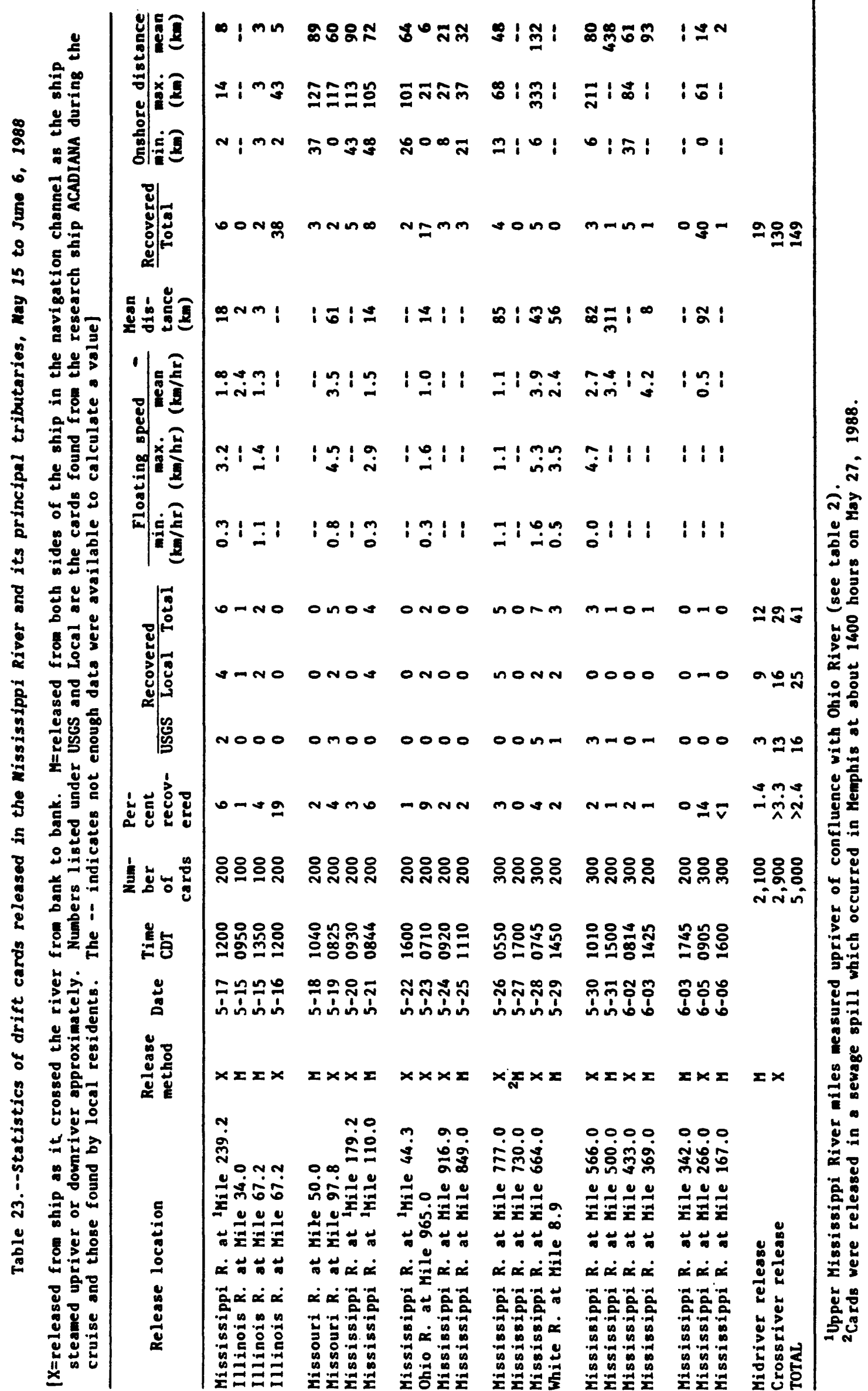


Table 24.--Surface-water travel time for river reaches between cross-section sampling sites on the Mississippi River and its principal tributaries, Nay 15 to June 6, 1988

[NA indicates reach includes tributary and mainstem Mississippi so that a single discharge is not appropriate. The .- indicates no data]

\begin{tabular}{|c|c|c|c|c|}
\hline River reach & $\begin{array}{l}\text { Length } \\
(\mathrm{km})\end{array}$ & $\begin{array}{l}\text { Mean } \\
\text { speed } \\
(\mathrm{m} / \mathrm{s})\end{array}$ & $\begin{array}{l}\text { Travel } \\
\text { time } \\
\text { (days) }\end{array}$ & $\begin{array}{l}\text { Water } \\
\text { discharge } \\
\left(\mathrm{m}^{3} / \mathrm{s}\right)\end{array}$ \\
\hline $\begin{array}{l}\text { Meredosia, Ill., to Mississippi-Illinois } \\
\text { River confluence }\end{array}$ & 108 & 0.45 & 2.8 & 330 \\
\hline $\begin{array}{l}\text { Winfield, Mo., to St. Louis, Mo. } \\
\text { Meredosia, Ili., to St. Louis, Mo. } \\
\text { Hermann, Mo., to St. Louis, Mo. } \\
\text { St. Louis, Mo., to Thebes, Ill. }\end{array}$ & $\begin{array}{r}97 \\
171 \\
183 \\
217\end{array}$ & $\begin{array}{l}0.49 \\
0.46 \\
0.98 \\
0.49\end{array}$ & $\begin{array}{l}2.3 \\
4.3 \\
2.2 \\
5.1\end{array}$ & $\begin{array}{l}1,700 \\
\text { NA } \\
1,500 \\
3,300\end{array}$ \\
\hline $\begin{array}{l}\text { Thebes, Ill., to Mississippi-Ohio River } \\
\text { confluence }\end{array}$ & 71 & $\ldots$ & -- & 3,600 \\
\hline $\begin{array}{l}\text { Olmsted, Ill., to Mississippi-Ohio River } \\
\text { confluence }\end{array}$ & 27 & 0.27 & 1.1 & 3,200 \\
\hline $\begin{array}{l}\text { Thebes, Ill., to Hickman, Ky. } \\
\text { Olmsted, Ill., to Hickman, Ky. } \\
\text { Hickman, Ky., to Fulton, Tenn. }\end{array}$ & $\begin{array}{r}131 \\
86 \\
140\end{array}$ & -- & -- & $\begin{array}{c}\text { NA } \\
\text { NA } \\
6,800\end{array}$ \\
\hline $\begin{array}{l}\text { Fulton, Tenn., to Helena, Ark. } \\
\text { Helena, Ark., to Mississippi-White River } \\
\text { confluence }\end{array}$ & $\begin{array}{l}182 \\
105\end{array}$ & $\begin{array}{l}0.31 \\
1.07\end{array}$ & $\begin{array}{l}6.7 \\
1.1\end{array}$ & $\begin{array}{l}7,200 \\
7,100\end{array}$ \\
\hline $\begin{array}{l}\text { White River at Mile } 8.9 \text { to Mississippi-White } \\
\text { River confluence }\end{array}$ & 14 & 0.67 & 0.2 & 440 \\
\hline $\begin{array}{l}\text { Helena, Ark., to Arkansas City, Ark. } \\
\text { White River at Mile } 8.9 \text { to Arkansas City, Ark. }\end{array}$ & $\begin{array}{r}158 \\
67\end{array}$ & $\begin{array}{l}1.07 \\
0.97\end{array}$ & $\begin{array}{l}1.7 \\
0.8\end{array}$ & $\begin{array}{l}7,100 \\
\text { NA }\end{array}$ \\
\hline $\begin{array}{l}\text { Arkansas City, Ark., to Vicksburg, Miss. } \\
\text { Vicksburg, Miss., to St. Francisville, La. } \\
\text { St. Francisville, La., to Belle Chasse, La. }\end{array}$ & $\begin{array}{l}214 \\
269 \\
311\end{array}$ & $\begin{array}{l}0.80 \\
0.65 \\
0.13\end{array}$ & $\begin{array}{r}3.1 \\
4.8 \\
27.7\end{array}$ & $\begin{array}{l}8,200 \\
8,000 \\
5,700\end{array}$ \\
\hline
\end{tabular}




\section{REFERENCES CITED}

Bragg, Marion, 1977, Historic names and places on the Mississippi River: Vicksburg, Miss., Mississippi River Commission, 282 p.

Guy, H.P., 1969, Laboratory theory and methods for sediment analysis: U.S. Geological Survey Techniques of Water-Resources Investigations, book 5, chap. $\mathrm{C} 1,58 \mathrm{p}$.

Guy, H.P., and Norman, V.W., 1970, Field methods for measurement of fluvial sediment: U.S. Geological Survey Techniques of Water-Resources Investigations, book 3 , chap. C2, $59 \mathrm{p}$.

Keown, M.P., Dardeau, E.A. Jr., Causey, E.M., 1981, Characterization of the suspended-sediment regime and bed-material gradation of the Mississippi River Basin: U.S. Army Corps of Engineers, New Orleans District, v. 1 and v. 2, 874 p.

Lara, 0.G., and Matthes, W.J., 1986, The Sedigraph as an alternative method to the pipet, in Proceedings of the Fourth Federal Interagency

Sedimentation Conference, March 24-27, 1986, v. 1: Las Vegas, Nev. Interagency Advisory Committee on Water Data, Subcommittee on Sedimentation, p. 1-1 to 1-12.

Leenheer, J.A., Meade, R.H., Taylor, H.E., and Pereira, W.E., 1989, Sampling, fractionation, and dewatering of suspended sediment from the Mississippi River for geochemical and trace-contaminant analysis, in Mallard, G.E., ed., U.S. Geological Survey Toxic Substances Hydrology Program--

Proceedings of the technical meeting, Phoenix, Arizona, September 26-30, 1988: U.S. Geological Survey Water-Resources Investigations Report 88-4220, p. 501-511.

Meade, R.H., and Stevens, H.H., Jr., 1990, Strategies and equipment for sampling suspended sediment and associated toxic chemicals in large rivers--with emphasis on the Mississippi River: Science of the Total Environment, v. 97/98, p. 125-135.

Moody, J.A., and Troutman, B.M., in press, Evaluation of the depth-integration method of measuring water discharge, Journal of Hydrology.

Nordin, C.F., Jr., Cranston, C.C., and Mejia-B., A., 1983, New technology for measuring water and suspended-sediment discharge of large rivers, in Proceedings of the International Symposium on River Sedimentation, 2d, Nanjing, China, October 11-16, 1983: Beijing, Water Resources and Electric Power Press, theme E, paper E20, p. 1145-1158.

Richey, J.E., Meade, R.H., Salati, E., Devol, A.H., Nordin, C.F., Jr., and dos Santos, U., 1986, Water discharge and suspended sediment concentrations in the Amazon River, 1982-1984: Water Resources Research, v. 22, no. 5, p. 756-764.

Stallard, R.F., and Martin, D.A., 1989, Settling properties of suspended sediment from the Mississippi River [abs.], in Pederson, G.L., and Smith, M.M., compilers, U.S. Geological Survey second national symposium on water quality; abstracts of the technical sessions, Orlando, Florida, November 12-17, 1989: U.S. Geological Survey Open-File Report 89-409, p. 96.

Stevens, H.H., Jr., Lutz, G.A., and Hubbe11, D.W., 1980, Collapsible-bag suspended-sediment sampler: American Society of Civil Engineers Proceedings, Hydraulics Division Journal, v. 106, no. HY4, p. 611-616.

U.S. Geological Survey, 1986, Water-resources data for Illinois, water year 1986, Volume 2. Illinois River Basin: U.S. Geological Survey Water-Data Report IL-86-2, 423 p. 1986, Water-resources data for Missouri, water year 1986, U.S. Geological Survey Water-Data Report M0-86-1, 325 p. 
The data in this section have been organized by cruises. In the listings of measurements made at each vertical the $A$ and $B$ after the vertical number indicates the composite, the $X$ indicates an extra velocity measurement was made but no sample was collected, and an $R$ indicates that the vertical was repeated because the velocity measurement was incorrect, the suspendedsediment collection bag leaked, or debris on the nozzle prevented the collection of a suitable sample. Verticals were usually occupied in numerical order. Exceptions due to weather conditions or towboat traffic have been noted under the REMARKS section of each cross-section listing. Inch-pound units appear in these listings as: (1) the designation of the nozzle used to sample suspended sediment, (2) gage heights which will serve as a reference for future cruises and can be more easily compared to existing gages in the field, (3) the name of a sampling weight, and (4) part of the name of a sampling cross section.

SOLID CUP refers to the standard Price AA current meter with solidpolymer bucket wheels, and OPEN CUP refers to the standard Price AA current meter with metal open cups. The SOLID CUP was used for the vertical integration measurements of discharge in this report because it does not respond to vertical velocities; later studies however, indicated that the SOLID CUP does not have a good cosine response to varying angles-of-attack and its use, by the USGS, has been discontinued.

Conductivity is reported in units of microsiemens per centimeter, which are equivalent to micromhos per centimeter. Conductivity has been temperature corrected to $25^{\circ} \mathrm{C}$ so that it is equivalent to specific conductance.

The following abbreviations are used in the tabulated cruise data and are listed below in the order that they appear in the listing.

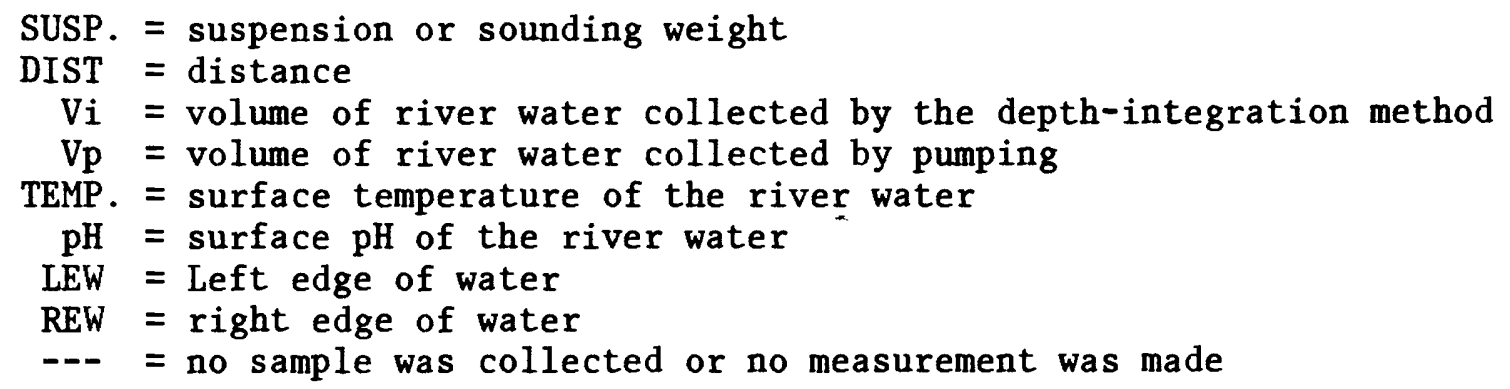


DATA LISTINGS

FOR

JULY 18 - AUGUST 9, 1987

CRUISE 
STATION: Mississippi River at Hartford, Ill.

PARTY: Black, Cranston, Stevens, and Moody

METER: SOLID CUP

STARTING GAGE HEIGHT: $3.00 \mathrm{ft}$ ENDING GAGE HEIGHT:

SUSP. Bag sampler and 200-1b weight

METER NO: P8308282 DATE RATED: $11-04-87$

WATER TEMP: $29.0^{\circ} \mathrm{Z}$

REMARKS: Transit rate was $13 \mathrm{~cm} / \mathrm{s}_{3}$ and nozzle was $5 / 16$ inch.

Total water discharge was $1380 \mathrm{~m} / \mathrm{s}$.

\begin{tabular}{|c|c|c|c|c|c|}
\hline $\begin{array}{c}\text { Verti- } \\
\text { cal }\end{array}$ & $\begin{array}{c}\text { Distance } \\
\text { from } \\
\text { LEW } \\
\text { (m) }\end{array}$ & Depth & $\begin{array}{c}\text { Mean } \\
\text { velocity } \\
(\mathrm{m} / \mathrm{s})\end{array}$ & $\begin{array}{l}\text { Discharge } \\
\\
\left(\mathrm{m}^{3} / \mathrm{s}\right)\end{array}$ & $\begin{array}{c}\text { Sample } \\
\text { volume } \\
\text { (mL) }\end{array}$ \\
\hline LEW & 0 & 0.0 & 0.00 & 0 & \\
\hline $32 \mathrm{~B}$ & 44 & 9.0 & 0.36 & 78 & 2740 \\
\hline $31 \mathrm{~A}$ & 48 & 9.4 & 0.39 & 42 & 2430 \\
\hline $30 B$ & 67 & 8.5 & 0.33 & 39 & 2510 \\
\hline $29 A$ & 76 & 8.7 & 0.45 & 45 & 2830 \\
\hline $28 B$ & 90 & 9.8 & 0.38 & 30 & 2270 \\
\hline $27 A$ & 92 & 9.8 & 0.44 & 39 & 2530 \\
\hline $26 B$ & 108 & 9.6 & 0.44 & 49 & 1650 \\
\hline $25 A$ & 115 & 9.8 & 0.52 & 28 & 3150 \\
\hline $24 B$ & 119 & 9.4 & 0.47 & 37 & 3190 \\
\hline $23 A$ & 132 & 9.3 & 0.51 & 50 & 2780 \\
\hline $22 B$ & 140 & 9.4 & 0.47 & 44 & 3280 \\
\hline $21 A$ & 152 & 9.1 & 0.52 & 48 & 3020 \\
\hline $20 B$ & 160 & 9.4 & 0.52 & 22 & 3460 \\
\hline $33 A$ & 161 & 9.1 & 0.53 & 22 & 2770 \\
\hline $19 A$ & 169 & 9.6 & 0.51 & 61 & 2750 \\
\hline $18 B$ & 186 & 9.6 & 0.51 & 47 & 3650 \\
\hline $15 A$ & 188 & 9.0 & 0.60 & 30 & 3610 \\
\hline $17 \mathrm{~A}$ & 197 & 9.8 & 0.50 & 54 & 3150 \\
\hline $16 \mathrm{~B}$ & 210 & 8.8 & 0.55 & 91 & 3860 \\
\hline $14 \mathrm{~B}$ & 235 & 8.5 & 0.54 & 79 & 3980 \\
\hline $13 A$ & 244 & 8.7 & 0.58 & 28 & 3400 \\
\hline $12 B$ & 246 & 8.5 & 0.52 & 22 & 3120 \\
\hline $34 \mathrm{~B}$ & 254 & 8.5 & 0.50 & 26 & 3810 \\
\hline $11 A$ & 258 & 8.2 & 0.52 & 30 & 3220 \\
\hline $10 B$ & 268 & 8.2 & 0.53 & 48 & 3630 \\
\hline $09 A$ & 280 & 8.2 & 0.53 & 41 & 2830 \\
\hline $08 B$ & 287 & 8.1 & 0.54 & 44 & 2990 \\
\hline $07 \AA$ & 300 & 7.9 & 0.49 & 48 & 2330 \\
\hline $06 B$ & 312 & 7.8 & 0.43 & 39 & 3110 \\
\hline $05 A$ & 323 & 7.6 & 0.50 & 42 & 2480 \\
\hline $03 A$ & 334 & 6.6 & 0.42 & 17 & 2360 \\
\hline $04 B$ & 335 & 7.2 & 0.43 & 8 & 2830 \\
\hline $35 A$ & 339 & 4.9 & 0.81 & 38 & 2040 \\
\hline $02 B$ & 354 & 4.0 & 0.41 & 16 & 1050 \\
\hline REW & 359 & 0.0 & 0.00 & 0 & \\
\hline
\end{tabular}

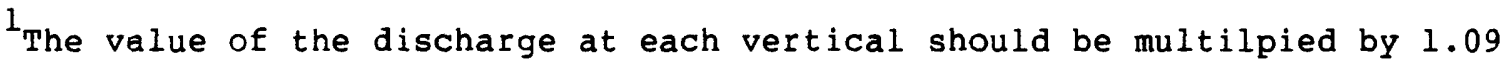
to give the correct discharge. See text under Water-Discharge Measurement for explanation. 


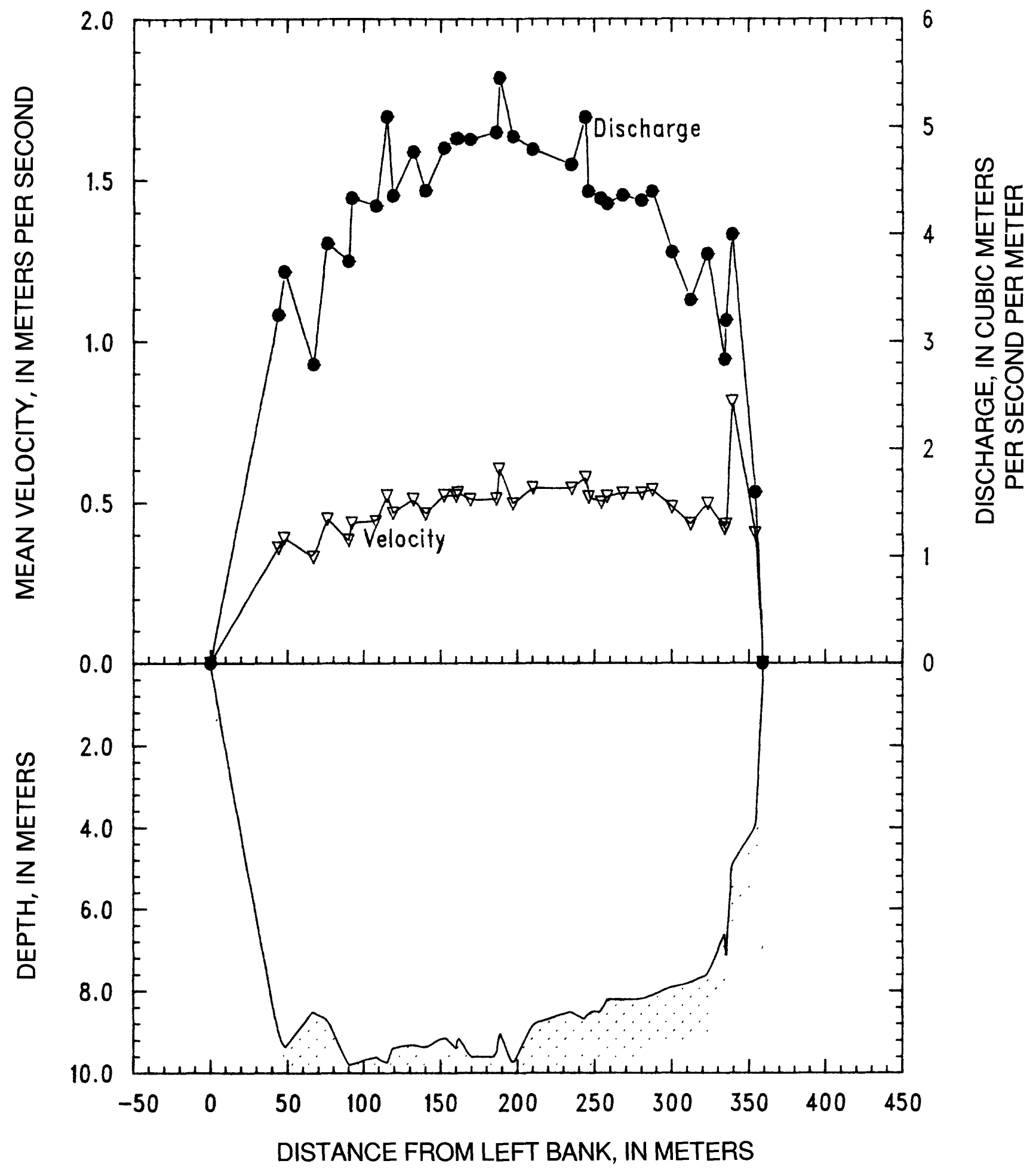

Figure 11. Mississippi River at Hartford, III. on July 21, 1987. 
STATION: Missouri River at Hermann, Mo.

07-20-87

PARTY: Black, Cranston, Stevens, and Moody

METER: SOLID CUP

STARTING GAGE HEIGHT: $13.78 \mathrm{ft}$ ENDING GAGE HEIGHT: --

SUSP. Bag sampler and 200-1b weight

METER NO: P8308282 DATE RATED: 11-04-87

WATER TEMP: $26.8^{\circ} \mathrm{C}$

REMARKS: Transit rate was $13 \mathrm{~cm} / \mathrm{s}_{3}$ and nozzle was $1 / 4$ inch

Total water discharge was $2560 \mathrm{~m}^{3} / \mathrm{s}$.

\begin{tabular}{|c|c|c|c|c|c|}
\hline $\begin{array}{l}\text { Verti- } \\
\text { cal }\end{array}$ & $\begin{array}{c}\text { Distance } \\
\text { from } \\
\text { LEW } \\
(\mathrm{m})\end{array}$ & Depth & $\begin{array}{c}\text { Mean } \\
\text { velocity } \\
(\mathrm{m} / \mathrm{s})\end{array}$ & $\begin{array}{c}\text { Discharge } \\
\left(\mathrm{m}^{3} / \mathrm{s}\right)\end{array}$ & $\begin{array}{l}\text { Sample } \\
\text { volume } \\
(\mathrm{mL})\end{array}$ \\
\hline LEW & 0 & 0.0 & 0.00 & 0 & -- \\
\hline $28 \mathrm{~A}$ & 18 & 7.0 & 0.49 & 60 & 1140 \\
\hline $27 B$ & 35 & 7.4 & 1.20 & 142 & 3040 \\
\hline $26 A$ & 50 & 6.9 & 1.24 & 107 & 3040 \\
\hline $25 B$ & 60 & 7.0 & 1.27 & 107 & 2990 \\
\hline $24 \mathrm{~A}$ & 74 & 6.8 & 1.38 & 122 & 3060 \\
\hline $23 B$ & 86 & 6.9 & 1.56 & 112 & 3510 \\
\hline $22 \mathrm{~A}$ & 95 & 6.2 & 1.44 & 117 & 1330 \\
\hline $21 B$ & 112 & 6.2 & 1.54 & 138 & 3390 \\
\hline $20 \mathrm{~A}$ & 124 & 6.4 & 1.50 & 120 & 2410 \\
\hline $19 B$ & 137 & 6.6 & 1.52 & 111 & 3000 \\
\hline $18 \mathrm{~A}$ & 146 & 6.4 & 1.37 & 114 & 3020 \\
\hline $17 \mathrm{~B}$ & 163 & 6.2 & 1.53 & 129 & 3730 \\
\hline $16 A$ & 173 & 6.6 & $i .54$ & 113 & 2840 \\
\hline $15 \mathrm{~B}$ & 185 & 6.4 & 1.55 & 108 & 3270 \\
\hline $14 \mathrm{~A}$ & 195 & 6.6 & 1.40 & 93 & 3030 \\
\hline $13 B$ & 205 & 6.2 & 1.56 & 131 & 2960 \\
\hline $12 \mathrm{~A}$ & 222 & 5.9 & 1.44 & 115 & 3240 \\
\hline $11 B$ & 232 & 5.6 & 1.27 & 75 & 2450 \\
\hline $10 \mathrm{~A}$ & 243 & 5.1 & 1.36 & 97 & 2870 \\
\hline O9B & 260 & 5.0 & 1.25 & 87 & 1820 \\
\hline $08 \mathrm{~A}$ & 271 & 4.4 & 1.17 & 72 & 1940 \\
\hline 07B & 288 & 4.5 & 0.96 & 76 & 1370 \\
\hline 06A & 306 & 5.3 & 0.87 & 63 & 1880 \\
\hline $05 B$ & 315 & 5.0 & 0.69 & 44 & 1200 \\
\hline $04 \mathrm{~A}$ & 331 & 4.7 & 0.69 & 47 & 620 \\
\hline $03 \mathrm{~B}$ & 344 & 4.6 & 0.46 & 25 & 445 \\
\hline $02 \mathrm{~A}$ & 355 & 4.7 & 0.37 & 20 & 275 \\
\hline $01 B$ & 367 & 4.0 & 0.26 & 11 & 240 \\
\hline REW & 377 & 0.0 & 0.00 & 0 & \\
\hline
\end{tabular}

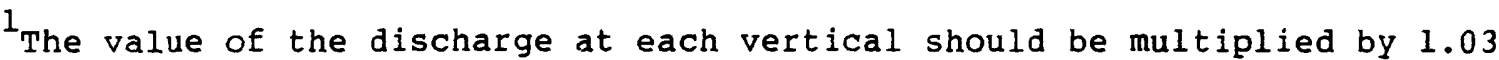
to give the correct discharge. See text under Water-Discharge Measurement for explanation. 


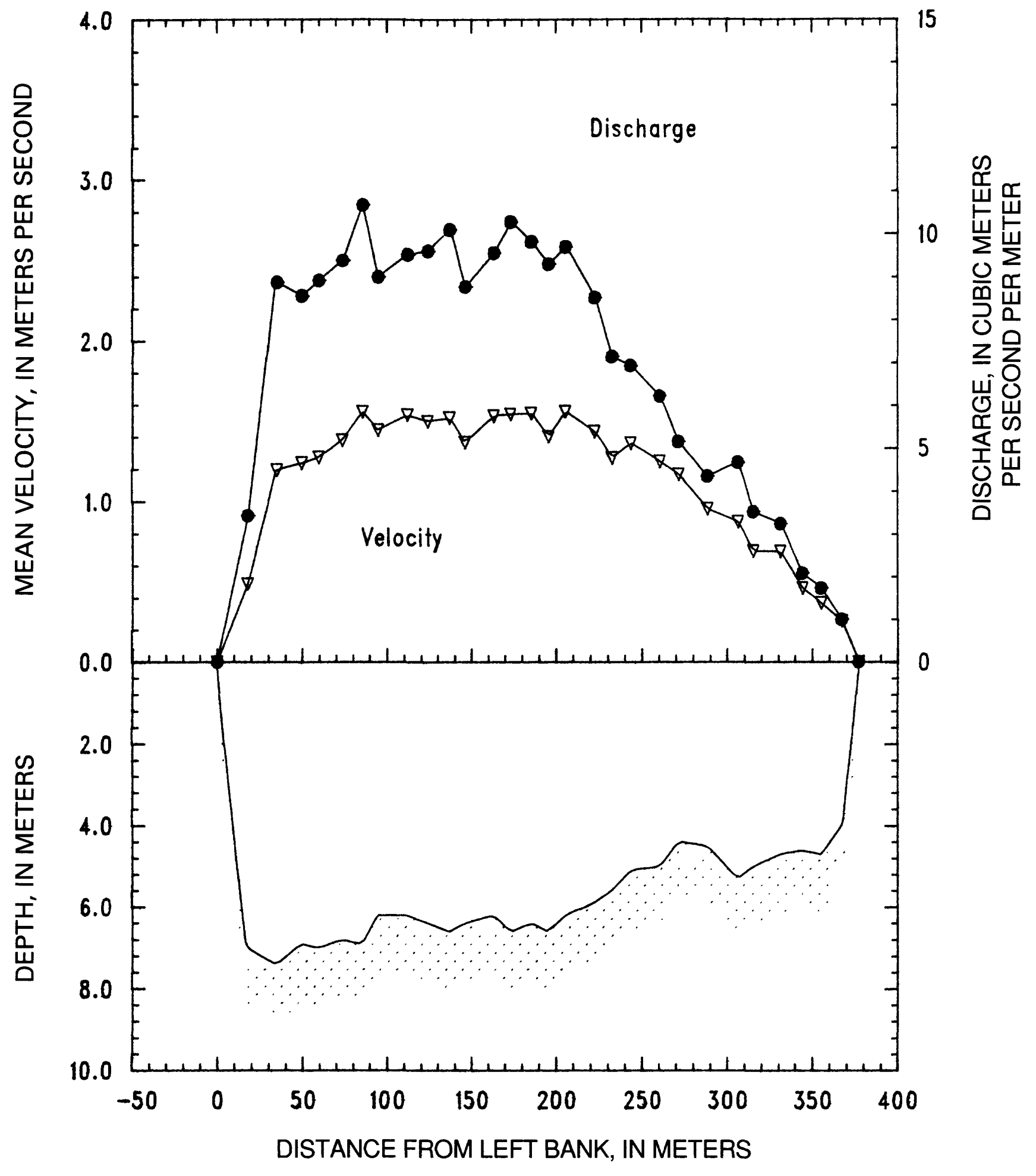

Figure 12. Missouri River at Hermann, Mo. on July 20, 1987 
STATION: Mississippi River at St. Louis, Mo.

PARTY: Black, Cranston, Stevens, and Moody

STARTING GAGE HEIGHT: 3.25 FT ENDING GAGE HEIGHT: --

SUSP. Bag sampler and 200-1b weight

METER NO: P8308282 DATE RATED: 11-04-87

WATER TEMP: $28.0^{\circ} \mathrm{C}$

REMARKS: Transit rate was $14, \mathrm{~cm} / \mathrm{s}$ and nozzle was $1 / 4$ inch.

Total discharge was $3830 \mathrm{~m}^{3} / \mathrm{s}$.

\begin{tabular}{|c|c|c|c|c|c|}
\hline $\begin{array}{l}\text { Verti- } \\
\text { cal }\end{array}$ & $\begin{array}{c}\text { Distance } \\
\text { from } \\
\text { LEW } \\
\text { (m) }\end{array}$ & Depth & $\begin{array}{l}\text { Mean } \\
\text { velocity } \\
(\mathrm{m} / \mathrm{s})\end{array}$ & $\begin{array}{c}\text { Discharge } \\
\left(\mathrm{m}^{3} / \mathrm{s}\right)\end{array}$ & $\begin{array}{c}\text { Sample } \\
\text { volume } \\
\text { (mL) }\end{array}$ \\
\hline LEW & 0 & 0.0 & 0.00 & 0 & -- \\
\hline $30 \mathrm{~B}$ & 31 & 9.4 & 1.14 & 177 & -- \\
\hline $29 R$ & 33 & 9.4 & 1.06 & 59 & -- \\
\hline $29 A$ & 43 & 9.6 & 1.25 & 108 & 4110 \\
\hline $28 B$ & 51 & 9.8 & 1.19 & 145 & 4970 \\
\hline $\mathrm{X} 02$ & 68 & 9.5 & 1.21 & 132 & -- \\
\hline $27 A$ & 74 & 9.7 & 1.19 & 121 & 4250 \\
\hline $26 B$ & 89 & 9.6 & 1.21 & 168 & 4980 \\
\hline $25 A$ & 103 & 9.4 & 1.14 & 134 & 3280 \\
\hline $24 B$ & 114 & 9.2 & 1.18 & 174 & 3700 \\
\hline $23 A$ & 135 & 9.0 & 1.19 & 181 & 3330 \\
\hline $22 B$ & 148 & 8.8 & 1.07 & 117 & 4040 \\
\hline $21 A$ & 160 & 8.5 & 1.20 & 127 & 3460 \\
\hline $20 \mathrm{~B}$ & 173 & 8.7 & 1.24 & 145 & 4160 \\
\hline $19 A$ & 187 & 8.2 & 1.16 & 171 & 3290 \\
\hline $18 \mathrm{~B}$ & 209 & 8.2 & 1.16 & 181 & 3910 \\
\hline $17 \mathrm{~A}$ & 225 & 8.0 & 1.16 & 135 & 2710 \\
\hline $16 \mathrm{~B}$ & 238 & 8.1 & 1.17 & 143 & 3520 \\
\hline $15 A$ & 255 & 7.8 & 1.16 & 159 & 3210 \\
\hline $14 \mathrm{~B}$ & 273 & 7.8 & 0.90 & 133 & 3440 \\
\hline $13 A$ & 293 & 7.6 & 0.99 & 90 & 3490 \\
\hline $12 B$ & 297 & 7.2 & 1.07 & 77 & 3350 \\
\hline $11 \mathrm{~A}$ & 313 & 7.2 & 1.05 & 125 & 2470 \\
\hline $10 \mathrm{~B}$ & 330 & 6.9 & 0.97 & 120 & 2180 \\
\hline $09 A$ & 349 & 6.0 & 1.01 & 97 & 2460 \\
\hline $08 B$ & 362 & 5.9 & 1.04 & 68 & 2590 \\
\hline $07 A$ & 371 & 6.4 & 0.98 & 89 & 2220 \\
\hline $06 \mathrm{~B}$ & 390 & 6.4 & 0.97 & 62 & 2440 \\
\hline $\mathrm{X} 01$ & 391 & 6.0 & 1.04 & 47 & -- \\
\hline $05 A$ & 405 & 5.9 & 0.99 & 87 & 2540 \\
\hline 04B & 421 & 5.9 & 0.97 & 85 & 2730 \\
\hline $03 A$ & 435 & 5.8 & 0.84 & 76 & 1910 \\
\hline $02 B$ & 452 & 5.9 & 0.70 & 54 & 1230 \\
\hline $01 \mathrm{~A}$ & 461 & 5.3 & 0.53 & 42 & 1090 \\
\hline REW & 482 & 0.0 & 0.00 & 0 & -- \\
\hline
\end{tabular}

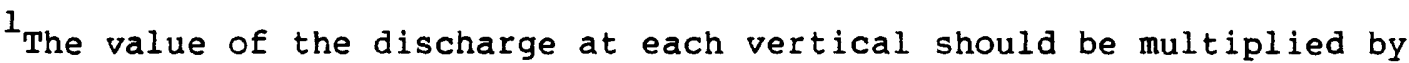
1.03 to give the correct discharge. See text under Water

Discharge Measurement for explanation. 


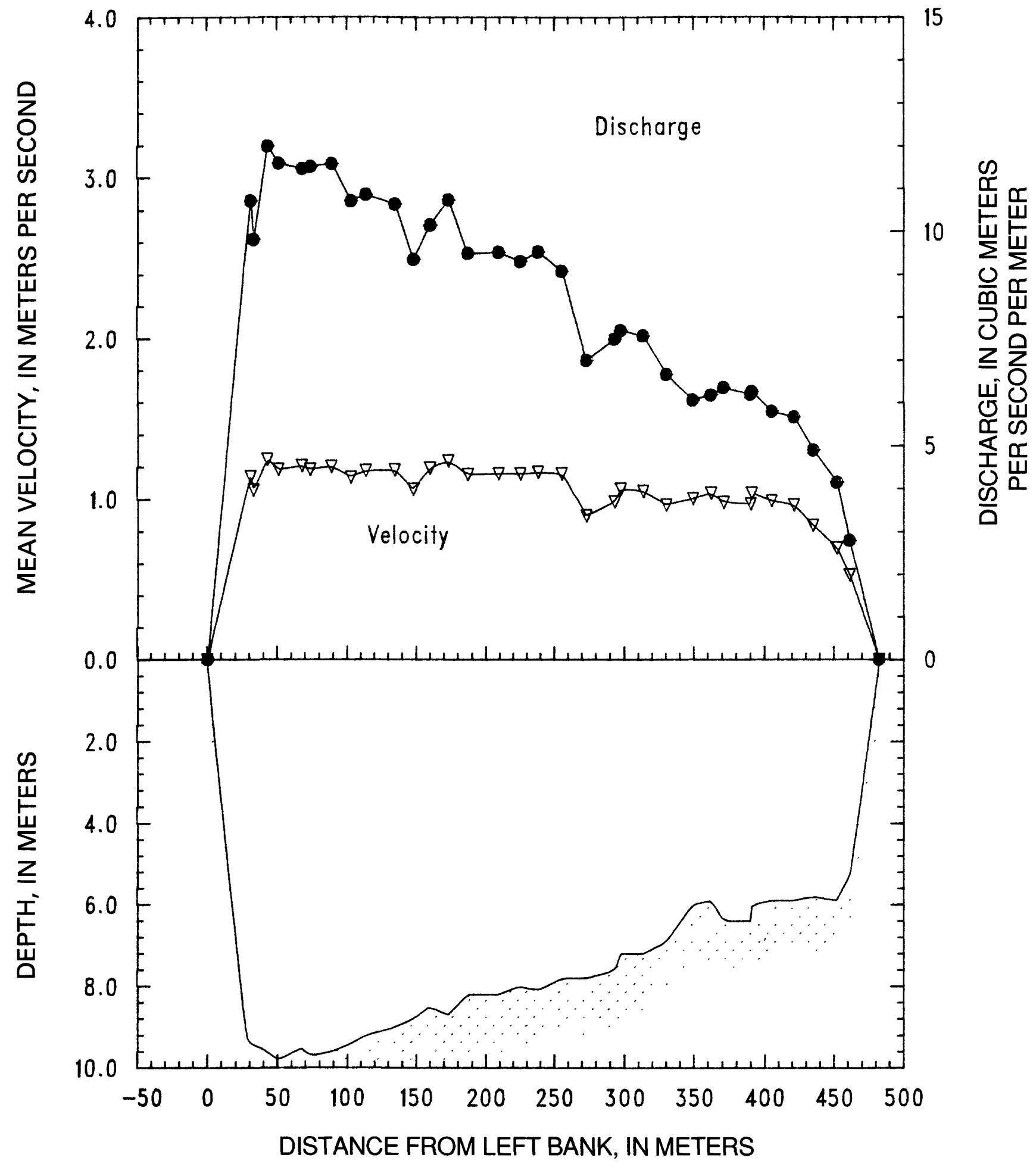

Figure 13. Mississippi River at St. Louis, Mo. on July 22, 1987. 
STATION: Mississippi River at Chester, Ill.

PARTY: Black, Moody, Cranston, and Stevens

STARTING GAGE HEIGHT: 9.3 FT ENDING GAGE HEIGHT: --

SUSP. Bag sampler and 200-1b weight

METER NO: P8308282 DATE RATED: 11-04-87

WATER TEMP: $28.5^{\circ} \mathrm{C}$

REMARKS: Transit rate was $14, \mathrm{~cm} / \mathrm{s}$ and nozzle was $1 / 4$ inch.

Total discharge was $4090 \mathrm{~m}^{3} / \mathrm{s}$.

\begin{tabular}{|c|c|c|c|c|c|}
\hline $\begin{array}{c}\text { Verti- } \\
\text { cal }\end{array}$ & $\begin{array}{c}\text { Distance } \\
\text { from } \\
\text { LEW } \\
\text { (m) }\end{array}$ & Depth & $\begin{array}{c}\text { Mean } \\
\text { velocity } \\
(\mathrm{m} / \mathrm{s})\end{array}$ & $\begin{array}{c}\text { Discharge } \\
1 \\
\left(\mathrm{~m}^{3} / \mathrm{s}\right)\end{array}$ & $\begin{array}{l}\text { Sample } \\
\text { volume } \\
(\mathrm{mL})\end{array}$ \\
\hline LE'W & 0 & 0.0 & 0.00 & 0 & -- \\
\hline $30 \mathrm{~B}$ & 20 & 4.9 & 0.51 & 48 & 880 \\
\hline $29 A$ & 38 & 6.6 & 0.90 & 109 & 1860 \\
\hline $28 \mathrm{~B}$ & 57 & 6.4 & 0.99 & 124 & 2320 \\
\hline $27 \mathrm{~A}$ & 77 & 6.1 & 1.12 & 130 & 2680 \\
\hline $26 \mathrm{~B}$ & 95 & 5.8 & 1.12 & 111 & 2390 \\
\hline $25 A$ & 111 & 5.8 & 1.51 & 201 & 2580 \\
\hline $24 B$ & 141 & 6.1 & 0.99 & 127 & 2960 \\
\hline $23 A$ & 153 & 6.1 & 1.40 & 110 & 2390 \\
\hline $22 \mathrm{~B}$ & 167 & 6.2 & 1.25 & 144 & 2390 \\
\hline $21 \mathrm{~A}$ & 190 & 6.4 & 1.30 & 187 & 2610 \\
\hline $20 B$ & 212 & 6.6 & 1.16 & 141 & 2830 \\
\hline $19 A$ & 227 & 7.0 & 1.10 & 135 & 3070 \\
\hline $18 \mathrm{~B}$ & 247 & 7.3 & 1.23 & 152 & 2590 \\
\hline $17 \mathrm{~A}$ & 261 & 7.3 & 1.08 & 153 & 2690 \\
\hline $16 \mathrm{~B}$ & 286 & 7.8 & 1.42 & 249 & 3440 \\
\hline $15 A$ & 306 & 7.6 & 1.15 & 158 & 3140 \\
\hline $14 \mathrm{~B}$ & 322 & 8.2 & 1.05 & 168 & 3100 \\
\hline $13 \mathrm{~A}$ & 345 & 8.2 & 1.07 & 185 & 2660 \\
\hline $12 \mathrm{~B}$ & 364 & 8.4 & 1.31 & 182 & 2970 \\
\hline $11 A$ & 378 & 7.9 & 1.20 & 180 & 3270 \\
\hline $10 \mathrm{~B}$ & 402 & 7.5 & 0.96 & 155 & 2690 \\
\hline $09 A$ & 421 & 6.7 & 0.87 & 111 & 2170 \\
\hline $08 \mathrm{~B}$ & 440 & 6.2 & 1.20 & 145 & 2150 \\
\hline $07 A$ & 460 & 6.1 & 1.14 & 108 & 1570 \\
\hline $06 \mathrm{~B}$ & 471 & 6.7 & 0.82 & 87 & 1820 \\
\hline $05 A$ & 492 & 6.7 & 0.76 & 115 & 1610 \\
\hline $04 \mathrm{~B}$ & 516 & 6.2 & 0.70 & 89 & 1670 \\
\hline $03 A$ & 533 & 6.1 & 0.78 & 81 & 1650 \\
\hline $02 \mathrm{~B}$ & 550 & 6.2 & 0.72 & 71 & 1670 \\
\hline $01 \mathrm{~A}$ & 565 & 6.1 & 1.09 & 136 & 1210 \\
\hline REW & 591 & 0.0 & 0.00 & 0 & -- \\
\hline
\end{tabular}

${ }^{1}$ The value of the discharge at each vertical should be multiplied by 1.04 to give the correct discharge. See text under water

Discharge Measurement for explanation. 


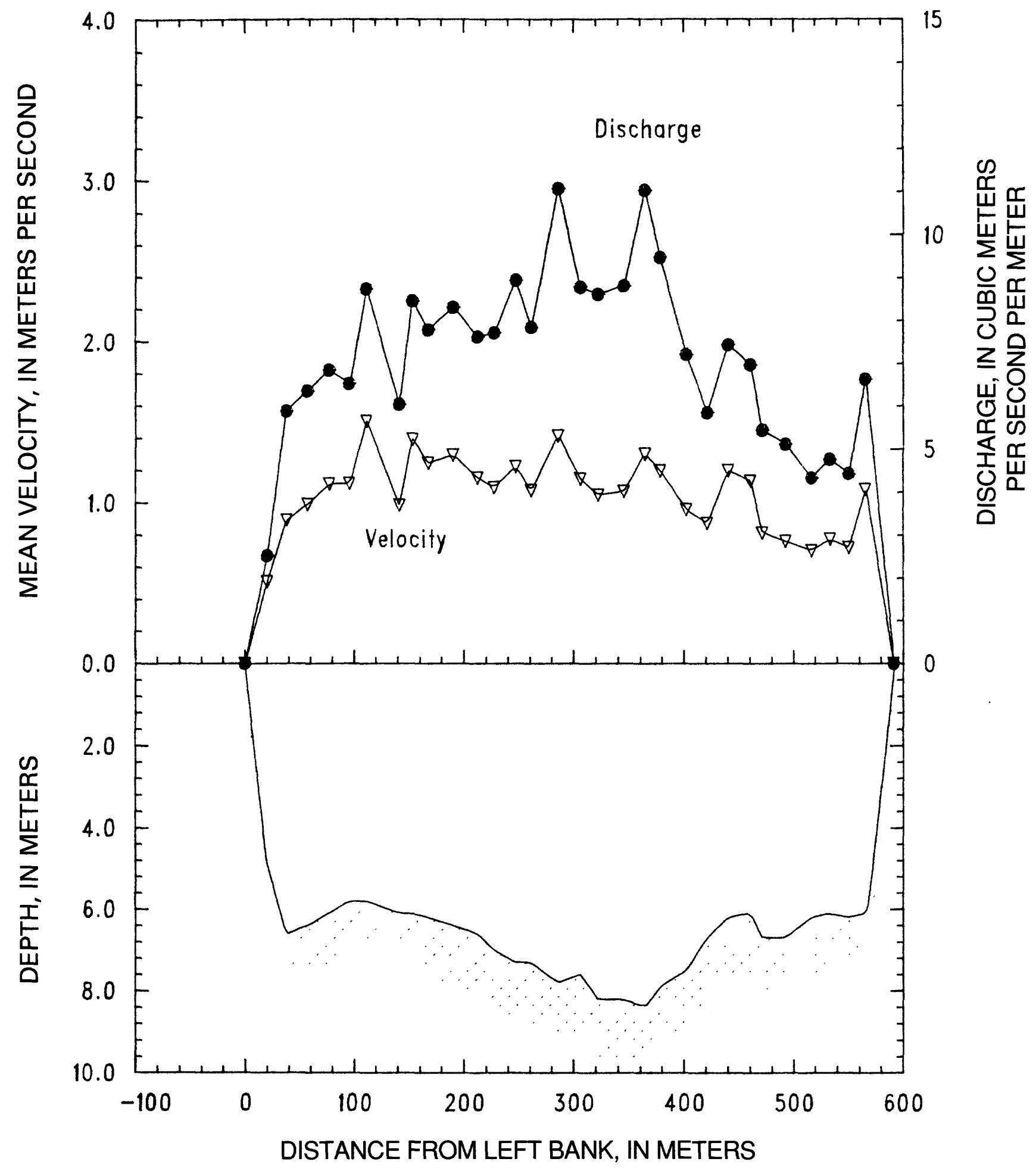

Figure 14. Mississippi River at Chester, III. on July 23, 1987. 
STATION: Ohio River at Olmsted, Ill.

PARTY: Black, Cranston, Stevens, and Moody

METER: SOLID CUP

STARTING GAGE HEIGHT: $14.9 \mathrm{ft}$ at Lock \& Dam 53 ENDING GAGE HEIGHT: -SUSP. Bag sampler and 200-1b weight

METER NO: P8308282 DATE RATED: 11-04-87

WATER TEMP: $\quad 30.5^{\circ} \mathrm{C}$ at vertical $19 \mathrm{~A}$ and $29.7^{\circ} \mathrm{C}$ at vertical $7 \mathrm{~A}$

REMARKS: Transit rate was $3 \mathrm{~cm} / \mathrm{s}$ for the downcast, $6-8 \mathrm{~cm} / \mathrm{s}$

for the upcast, and 3 the nozzle was $5 / 16$ inch. The total

discharge was $1970 \mathrm{~m}^{3} / \mathrm{s}$.

\begin{tabular}{|c|c|c|c|c|c|}
\hline $\begin{array}{c}\text { Verti- } \\
\text { cal }\end{array}$ & $\begin{array}{l}\text { Distance } \\
\text { from } \\
\text { LEW } \\
\text { (m) }\end{array}$ & Depth & $\begin{array}{c}\text { Mean } \\
\text { velocity } \\
(m / s)\end{array}$ & $\begin{array}{c}\text { Discharge } \\
\left(\mathrm{m}^{3} / \mathrm{s}\right)\end{array}$ & $\begin{array}{c}\text { Sample } \\
\text { volume } \\
(\mathrm{mL})\end{array}$ \\
\hline LEW & 0 & 0.0 & 0.00 & 0 & -- \\
\hline $28 B$ & 45 & 1.8 & 0.16 & 16 & 280 \\
\hline $27 A$ & 115 & 1.9 & 0.22 & 19 & 530 \\
\hline $26 B$ & 136 & 2.2 & 0.17 & 12 & 300 \\
\hline $25 A$ & 181 & 3.0 & 0.21 & 27 & 720 \\
\hline $24 B$ & 220 & 3.9 & 0.23 & 28 & 680 \\
\hline $23 A$ & 244 & 3.7 & 0.26 & 21 & 1050 \\
\hline $22 B$ & 265 & 3.4 & 0.31 & 29 & 1040 \\
\hline $21 \mathrm{~A}$ & 299 & 3.8 & 0.32 & 46 & 1480 \\
\hline $20 \mathrm{~B}$ & 339 & 5.0 & 0.31 & 48 & 2450 \\
\hline $19 A$ & 360 & 5.7 & 0.33 & 34 & 3030 \\
\hline $18 \mathrm{~B}$ & 375 & 6.0 & 0.31 & 63 & 2640 \\
\hline $17 \mathrm{~A}$ & 427 & 6.6 & 0.36 & 80 & 3200 \\
\hline $16 \mathrm{~B}$ & 443 & 6.7 & 0.37 & 65 & 2710 \\
\hline $15 \mathrm{~A}$ & 479 & 6.7 & 0.38 & 86 & 4280 \\
\hline $14 \mathrm{~B}$ & 510 & 7.2 & 0.39 & 81 & 4100 \\
\hline $13 A$ & 537 & 6.7 & 0.47 & 88 & 4970 \\
\hline $12 \mathrm{~B}$ & 566 & 6.7 & 0.57 & 134 & 3520 \\
\hline $11 \mathrm{~A}$ & 607 & 7.2 & 0.51 & 115 & 4650 \\
\hline $10 \mathrm{~B}$ & 629 & 7.2 & 0.47 & 85 & 3900 \\
\hline $09 \mathrm{~A}$ & 657 & 7.2 & 0.51 & 123 & 4690 \\
\hline 08B & 696 & 7.2 & 0.50 & 114 & 5140 \\
\hline $07 A$ & 720 & 7.2 & 0.48 & 119 & 5090 \\
\hline $06 \mathrm{~B}$ & 764 & 7.3 & 0.47 & 101 & 5170 \\
\hline $05 \mathrm{~A}$ & 779 & 7.2 & 0.46 & 80 & 6160 \\
\hline $04 \mathrm{~B}$ & 812 & 7.5 & 0.49 & 106 & 4440 \\
\hline $03 \mathrm{~A}$ & 837 & 7.9 & 0.40 & 99 & 4620 \\
\hline O2B & 874 & 8.0 & 0.35 & 89 & 4020 \\
\hline $01 \mathrm{~A}$ & 901 & 7.6 & 0.29 & 61 & 3540 \\
\hline REW & 930 & 0.0 & 0.00 & 0 & - \\
\hline
\end{tabular}

${ }^{1}$ The value of the discharge at each vertical should be multiplied by 1.05 to give the correct discharge. See text under water Discharge Measurement for explanation. 


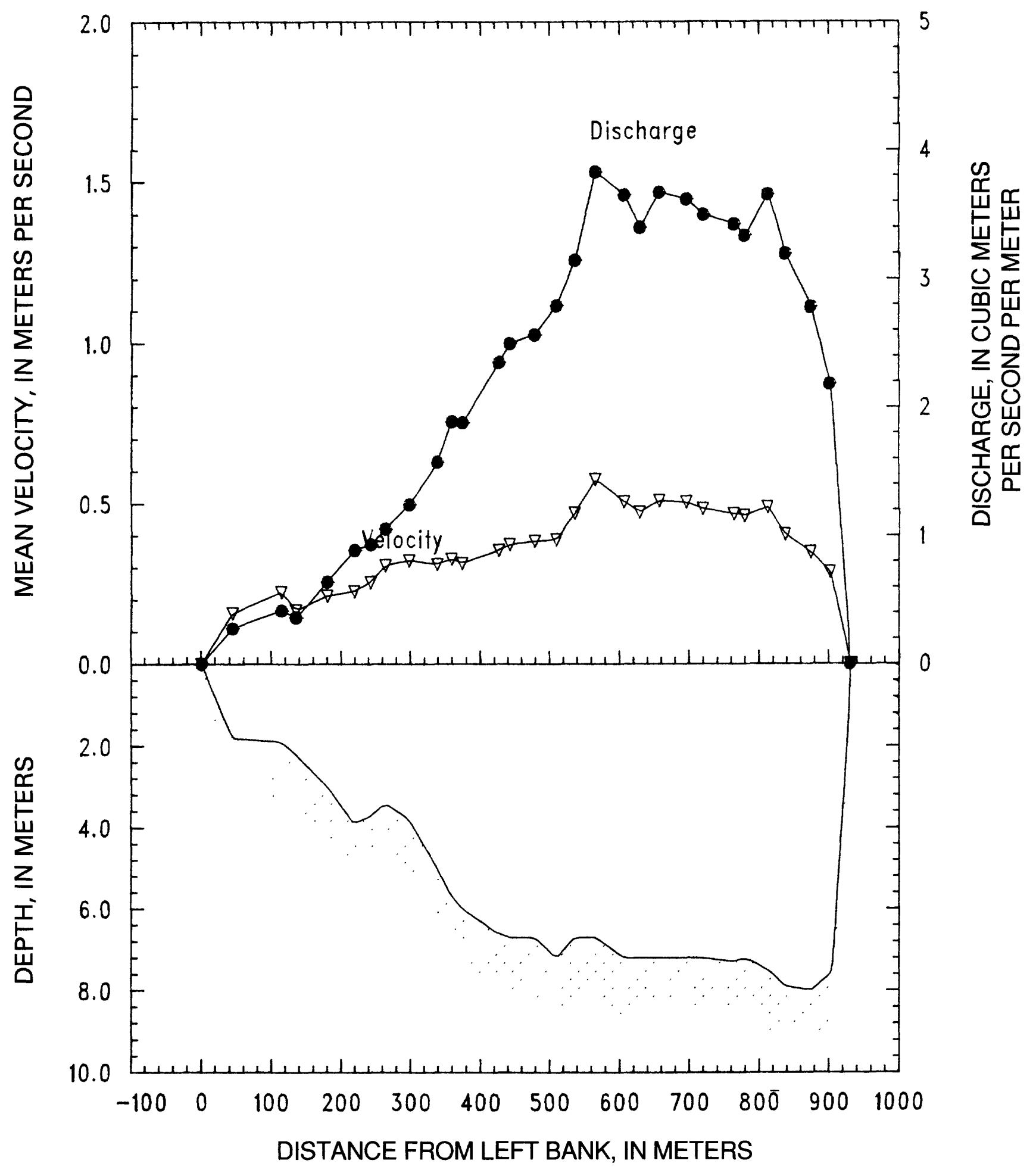

Figure 15. Ohio River at Olmsted, III. on July 27, 1987. 
STATION: Mississippi River below Hickman, Ry.

PARTY: Black, Cranston, Moody, and Stevens

STARTING GAGE HEIGHT: $8.7 \mathrm{ft}$ ENDING GAGE HEIGHT: --

SUSP. Bag sampler and 200-1b weight

METER NO: P8308282 DATE RATED: 11-04-87

WATER TEMP: $29.5^{\circ} \mathrm{C}$

REMARKS: Transit rate was $10 \mathrm{~cm} / \mathrm{s}$ and the nozzle was $1 / 4$ inch.

The total discharge was $6090 \mathrm{~m}^{3} / \mathrm{s}$.

\begin{tabular}{|c|c|c|c|c|c|}
\hline $\begin{array}{c}\text { Verti- } \\
\text { cal }\end{array}$ & $\begin{array}{c}\text { Distance } \\
\text { Erom } \\
\text { LEW } \\
\text { (m) }\end{array}$ & Depth & $\begin{array}{c}\text { Mean } \\
\text { velocity }\end{array}$ & $\begin{array}{l}\text { Discharge } \\
{\left(m^{3} / \mathrm{s}\right)}^{1}\end{array}$ & $\begin{array}{c}\text { Sample } \\
\text { volume } \\
\text { (mL) }\end{array}$ \\
\hline LEW & 0 & 0.0 & 0.00 & 0 & -- \\
\hline $30 \mathrm{~B}$ & 28 & 5.6 & 0.74 & 148 &, 1920 \\
\hline $31 A$ & 71 & 6.9 & 1.01 & 160 & ${ }_{4340}$ \\
\hline $29 A$ & 74 & 6.7 & 1.06 & 139 & 2970 \\
\hline $28 B$ & 110 & 6.9 & 1.08 & 253 & 3895 \\
\hline $27 A$ & 142 & 6.6 & 1.22 & 218 & 3680 \\
\hline $26 B$ & 164 & 6.6 & 1.11 & 212 & 3510 \\
\hline $25 A$ & 200 & 6.7 & 1.20 & 281 & 2560 \\
\hline $24 B$ & 234 & 6.0 & 1.28 & 299 & 2930 \\
\hline $23 A$ & 278 & 5.9 & 1.13 & 203 & 2670 \\
\hline $22 \mathrm{~B}$ & 295 & 5.7 & 1.09 & 140 & 3150 \\
\hline $21 A$ & 323 & 4.9 & 1.06 & 200 & 3350 \\
\hline $20 B$ & 372 & 5.4 & 1.14 & 244 & 2710 \\
\hline $19 A$ & 402 & 5.5 & 1.05 & 189 & 2640 \\
\hline $18 \mathrm{~B}$ & 437 & 5.9 & 0.99 & 194 & 2820 \\
\hline $17 A$ & 468 & 5.5 & 1.12 & 200 & 2630 \\
\hline $16 \mathrm{~B}$ & 502 & 5.6 & 1.01 & 164 & 2800 \\
\hline $15 \mathrm{~A}$ & 526 & 5.4 & 1.08 & 160 & 2670 \\
\hline $14 \mathrm{~B}$ & 557 & 5.9 & 1.04 & 175 & 2800 \\
\hline $13 A$ & 583 & 5.9 & 1.04 & 151 & 2760 \\
\hline $12 \mathrm{~B}$ & 606 & 6.4 & 0.94 & 175 & 3140 \\
\hline $11 \mathrm{~A}$ & 641 & 7.7 & 1.01 & 238 & 3190 \\
\hline $10 \mathrm{~B}$ & 667 & 7.0 & 1.05 & 210 & 3290 \\
\hline $09 A$ & 698 & 7.5 & 0.92 & 213 & 3130 \\
\hline $08 \mathrm{~B}$ & 729 & 7.0 & 0.99 & 237 & 3570 \\
\hline $07 A$ & 766 & 7.2 & 0.90 & 269 & 2980 \\
\hline $06 \mathrm{~B}$ & 812 & 6.9 & 0.88 & 233 & 3350 \\
\hline $05 B$ & 843 & 6.4 & 0.86 & 160 & 3010 \\
\hline O4B & 870 & 7.4 & 0.82 & 176 & 2140 \\
\hline $03 A$ & 901 & 7.5 & 0.82 & 118 &, 2910 \\
\hline $32 \mathrm{~A}$ & 908 & 7.1 & 0.90 & 93 & 3500 \\
\hline 02B & 930 & 7.5 & 0.78 & 161 & 2710 \\
\hline $01 A$ & 963 & 3.9 & 0.62 & 79 & 1120 \\
\hline REW & 995 & 0.0 & 0.00 & 0 & -- \\
\hline
\end{tabular}

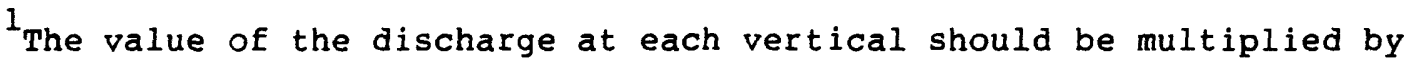
1.03 to give the correct discharge. See text under Water

Discharge Measurement for explanation.
2 separate samples--not part of either composite 


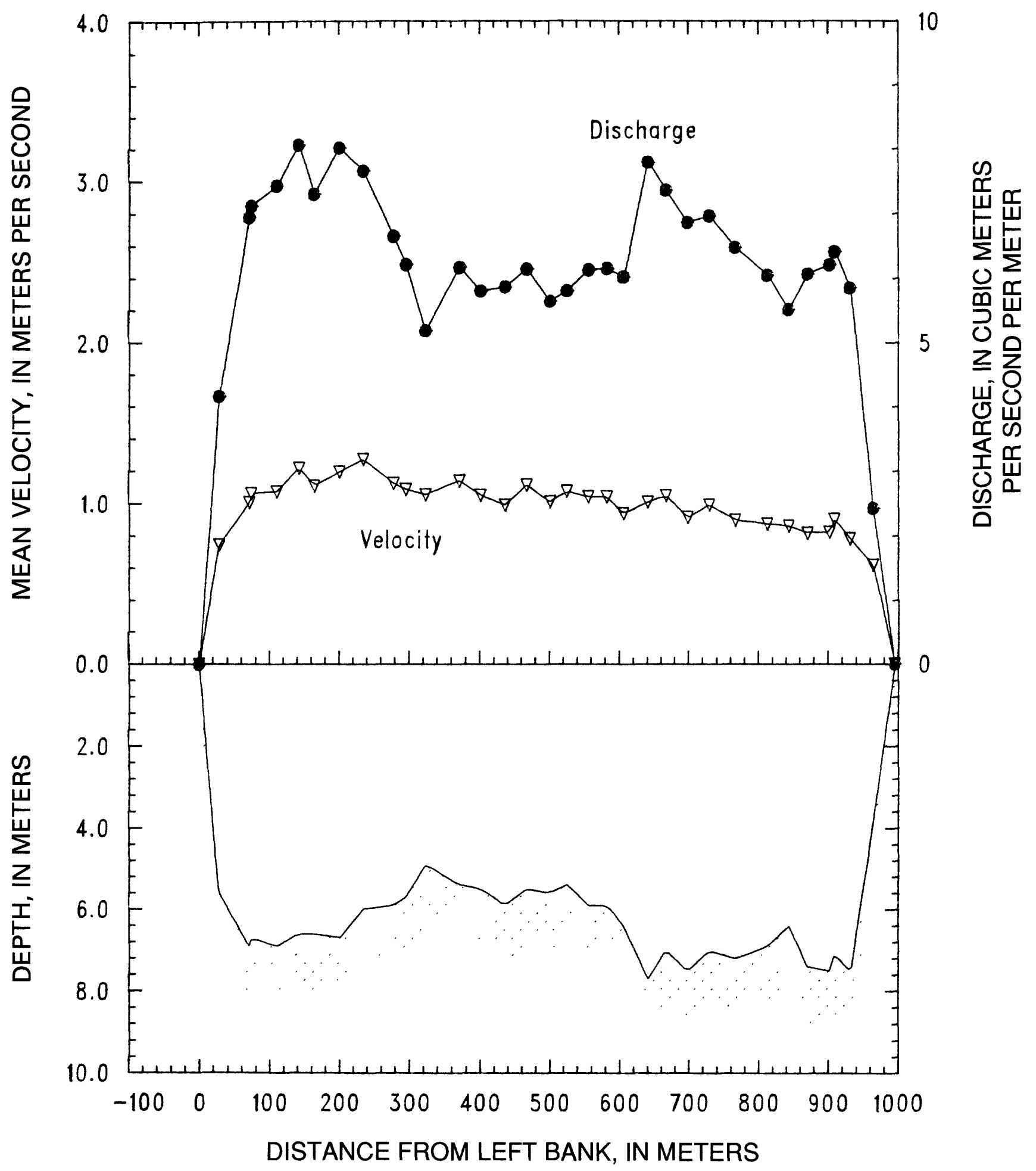

Figure 16. Mississippi River below Hickman, Ky. on July 28, 1987. 
STATION: Mississippi River at Helena, Ark.

PARTY: Black, Moody, Cranston, Stevens and Noyes METER: SOLID CUP STARTING GAGE HEIGHT: $6.52 \mathrm{ft}$ ENDING GAGE HEIGHT: $6.38 \mathrm{ft}$

SUSP. Bag sampler and 200-1b weight

METER NO: P8308282 DATE RATED: 11-04-87

WATER TEMP: $\quad 30.0^{\circ} \mathrm{C}$

REMARKS: Transit rate was $13 \mathrm{~cm} / \mathrm{s}$ and nozzle was $1 / 4$ inch.

The total discharge was $6720 \mathrm{~m}^{3} / \mathrm{s}$.

\begin{tabular}{|c|c|c|c|c|c|}
\hline $\begin{array}{c}\text { Verti- } \\
\text { cal }\end{array}$ & $\begin{array}{c}\text { Distance } \\
\text { from } \\
\text { LEW } \\
\text { (m) }\end{array}$ & Depth & $\begin{array}{c}\text { Mean } \\
\text { velocity } \\
(\mathrm{m} / \mathrm{s})\end{array}$ & $\begin{array}{l}\text { Discharge } \\
1 \\
\left(\mathrm{~m}^{3} / \mathrm{s}\right)\end{array}$ & $\begin{array}{l}\text { Sample } \\
\text { volume } \\
\text { (mL) }\end{array}$ \\
\hline LEW & 0 & 0.0 & 0.00 & 0 & -- \\
\hline $30 \mathrm{~B}$ & 24 & 6.5 & 1.58 & 196 & 3170 \\
\hline $29 A$ & 38 & 8.5 & 1.75 & 409 & 4540 \\
\hline $28 B$ & 79 & 9.2 & 1.62 & 410 & 4700 \\
\hline $27 A$ & 93 & 9.3 & 1.74 & 308 & 4980 \\
\hline $26 B$ & 117 & 9.3 & 1.74 & 316 & 5070 \\
\hline $25 A$ & 132 & 9.3 & 1.61 & 277 & 3880 \\
\hline $24 B$ & 154 & 9.3 & 1.60 & 364 & 5460 \\
\hline $23 A$ & 181 & 9.1 & 1.57 & 314 & 5760 \\
\hline $22 B$ & 198 & 9.0 & 1.51 & 259 & 4840 \\
\hline $21 \mathrm{~A}$ & 219 & 8.8 & 1.50 & 284 & 5070 \\
\hline $20 B$ & 241 & 8.6 & 1.49 & 290 & 4780 \\
\hline $19 A$ & 264 & 8.3 & 1.41 & 269 & 4490 \\
\hline $18 B$ & 287 & 8.3 & 1.42 & 241 & 4540 \\
\hline $17 \mathrm{~A}$ & 305 & 8.6 & 1.33 & 246 & 4840 \\
\hline $16 \mathrm{~B}$ & 330 & 8.4 & 1.32 & 260 & 4590 \\
\hline $15 A$ & 352 & 8.2 & 1.35 & 233 & 4130 \\
\hline $14 \mathrm{~B}$ & 372 & 8.0 & 1.35 & 228 & 3700 \\
\hline $13 \mathrm{~A}$ & 394 & 8.0 & 1.25 & 205 & 4410 \\
\hline $12 B$ & 413 & 7.3 & 1.28 & 196 & 3700 \\
\hline $11 \mathrm{~A}$ & 436 & 7.3 & 1.38 & 226 & 4050 \\
\hline $10 B$ & 458 & 8.0 & 1.19 & 172 & 3360 \\
\hline $09 A$ & 472 & 7.4 & 1.23 & 214 & 4080 \\
\hline $08 B$ & 505 & 6.2 & 1.28 & 209 & 3410 \\
\hline 07A & 525 & 5.8 & 1.22 & 124 & 2400 \\
\hline $06 \mathrm{~B}$ & 540 & 5.5 & 1.10 & 146 & 2390 \\
\hline $05 A$ & 573 & 4.3 & 1.09 & 122 & 1940 \\
\hline $04 \mathrm{~B}$ & 592 & 3.2 & 1.03 & 53 & 1440 \\
\hline $03 A$ & 605 & 2.5 & 0.87 & 38 & 840 \\
\hline $02 \mathrm{~B}$ & 626 & 2.3 & 1.03 & 54 & 950 \\
\hline $01 \mathrm{~A}$ & 650 & 1.8 & 0.94 & 63 & 600 \\
\hline REW & 701 & 0.0 & 0.00 . & 0 & -- \\
\hline
\end{tabular}

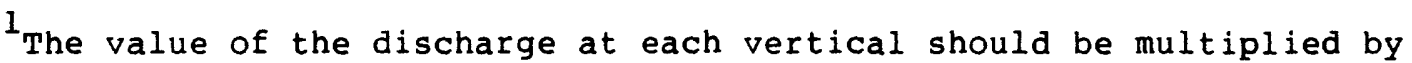
1.02 to give the correct discharge. See text under Water Discharge Measurement for explanation. 


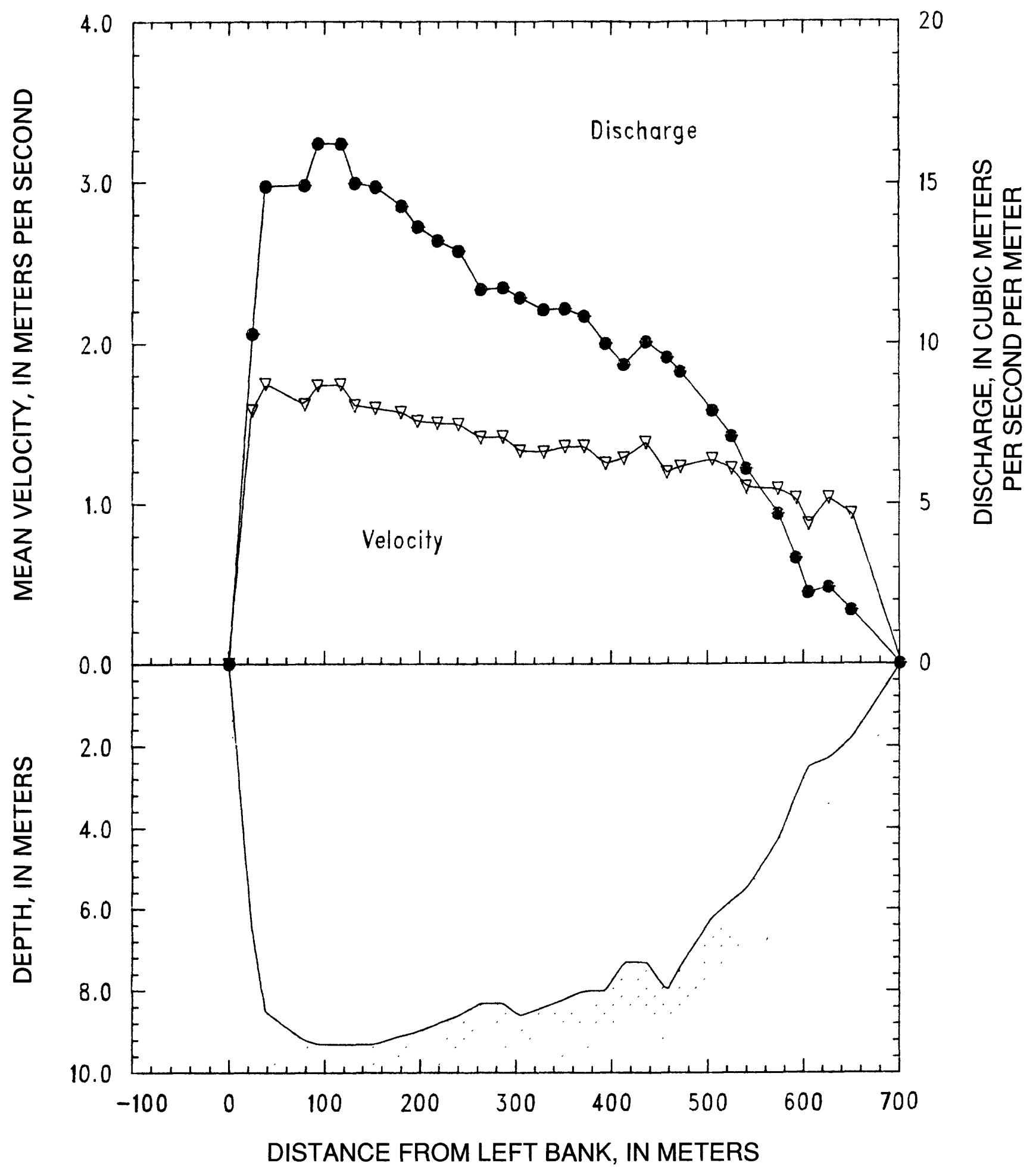

Figure 17. Mississippi River at Helena, Ark. on July 30, 1987. 
STATION: White River at Mile 11.5, Ark.

PARTY: Black, Cranston, Stevens, and Moody

METER: SOLID CUP

STARTING GAGE HEIGHT: $20.8 \mathrm{ft}$ at tailwater gage on Norrell Lock

SUSP. Bag sampler and 200-1b weight

METER NO: P8308282 DATE RATED: 11-04-87

WATER TEMP: $\quad 30.9^{\circ} \mathrm{C}$

REMARKS: Transit rate was $4 \mathrm{~cm} / \mathrm{s}$ for the downcast, $8 \mathrm{~cm} / \mathrm{s}$

for the 3 upcast, and the nozzle was $5 / 16$. Total discharge

was $322 \mathrm{~m}^{3} / \mathrm{s}$.

\begin{tabular}{lrlcll}
\hline $\begin{array}{l}\text { Verti- } \\
\text { cal }\end{array}$ & $\begin{array}{c}\text { Distance } \\
\text { from } \\
\text { LEW } \\
(\mathrm{m})\end{array}$ & Depth & $\begin{array}{c}\text { Mean } \\
\text { velocity }\end{array}$ & Discharge & $\begin{array}{c}\text { Sample } \\
\text { volume }\end{array}$ \\
& $(\mathrm{m})$ & $(\mathrm{m} / \mathrm{s})$ & $\left(\mathrm{m}^{3} / \mathrm{s}\right)$ & $(\mathrm{mL})$ \\
\hline
\end{tabular}

\begin{tabular}{lrllcc} 
LEW & 0 & 0.0 & 0.00 & 0 & -- \\
10A & 12 & 3.2 & 0.66 & 30 & 5230 \\
10B & 12 & 3.2 & 0.66 & -- & 4790 \\
09A & 29 & 3.3 & 0.76 & 39 & 6610 \\
09B & 29 & 3.3 & 0.76 & -- & 6310 \\
08A & 43 & 3.1 & 0.71 & 32 & 5710 \\
08B & 43 & 3.1 & 0.71 & -- & 5970 \\
07A & 58 & 3.1 & 0.74 & 38 & 5650 \\
07B & 58 & 3.1 & 0.74 & -- & 5560 \\
06A & 76 & 3.2 & 0.66 & 41 & 6080 \\
06B & 76 & 3.2 & 0.66 & -- & 5390 \\
05A & 97 & 3.0 & 0.65 & 37 & 5120 \\
05B & 97 & 3.0 & 0.65 & -- & 4840 \\
04A & 113 & 2.8 & 0.60 & 27 & 4330 \\
04B & 113 & 2.8 & 0.60 & -- & 4740 \\
03A & 129 & 3.0 & 0.59 & 22 & 4520 \\
03B & 129 & 3.0 & 0.59 & -- & 4030 \\
02A & 138 & 2.9 & 0.59 & 28 & 4070 \\
02B & 138 & 2.9 & 0.59 & -- & 4510 \\
01A & 162 & 3.3 & 0.56 & 28 & 4500 \\
01B & 162 & 3.3 & 0.56 & -- & 4740 \\
REW & 168 & 0.0 & 0.00 & 0 & -- \\
\hline
\end{tabular}

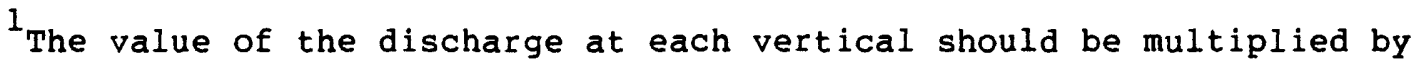
1.03 to give the correct discharge. See text under Water Discharge Measurement for explanation. 


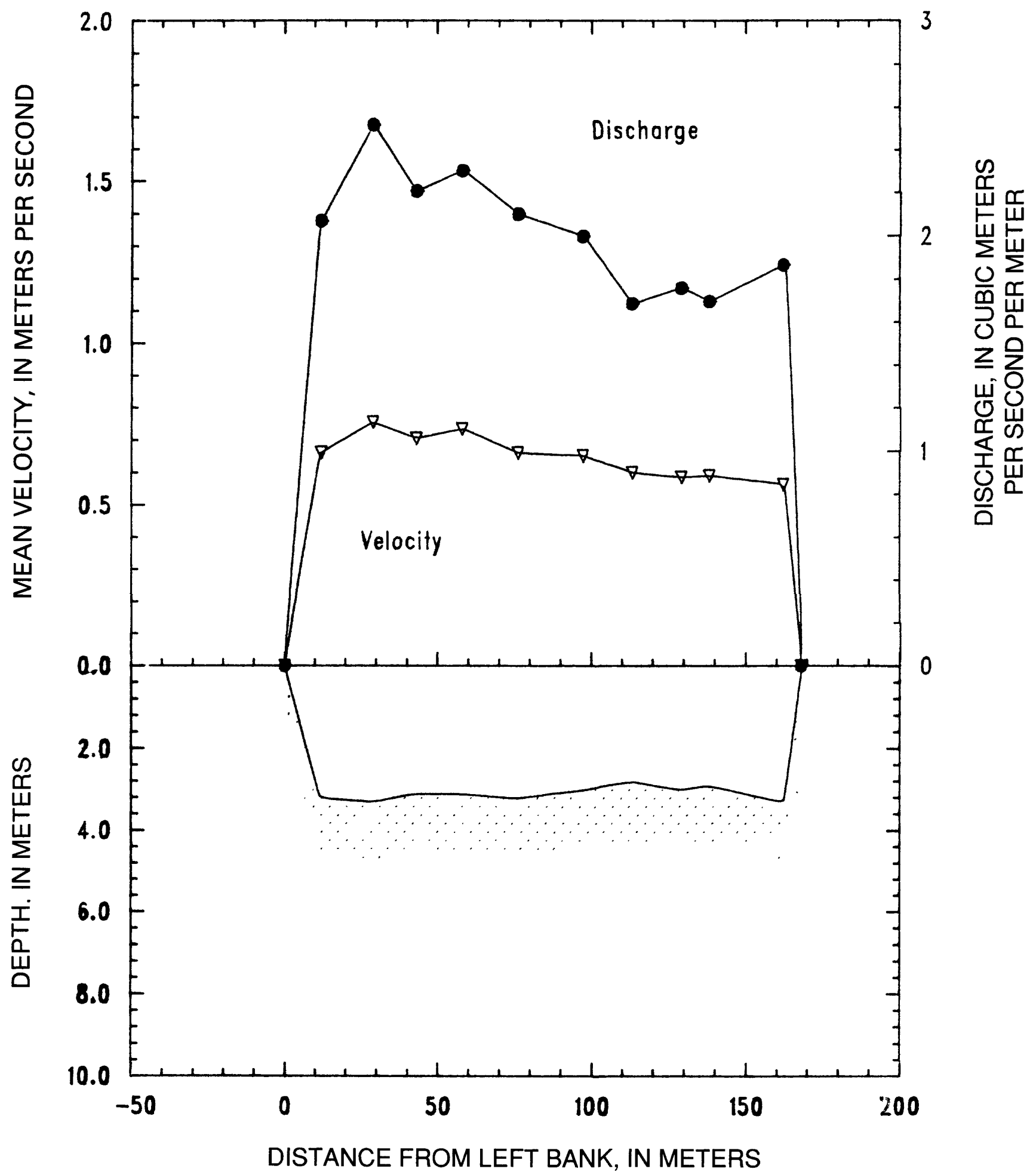

Figure 18. White River at Mile 11.5, Ark. on July 31, 1987. 
STATION: Arkansas River at Mile 55.9, Ark.

08-01-87

PARTY: Black, Moody, Stevens, and Cranston

METER: SOLID CUP

STARTING GAGE HEIGHT: --

ENDING GAGE HEIGHT: --

SUSP. Bag sampler and 200-1b weight

METER No: P8308282

WATER TEMP: $31.1--31.9^{\circ} \mathrm{C}$

DATE RATED: 11-04-87

REMARKS :

Transit rate was $9 \mathrm{~cm} / \mathrm{s}$, and the nozzle was $5 / 16$ inch.

The total discharge was $750 \mathrm{~m}^{3} / \mathrm{s}$.

\begin{tabular}{|c|c|c|c|c|c|}
\hline $\begin{array}{c}\text { Verti- } \\
\text { cal }\end{array}$ & $\begin{array}{c}\text { Distance } \\
\text { from } \\
\text { LEW } \\
\text { (m) }\end{array}$ & Depth & $\begin{array}{c}\text { Mean } \\
\text { velocity } \\
(m / s)\end{array}$ & $\begin{array}{c}\text { Discharge } \\
\left(\mathrm{m}^{3} / \mathrm{s}\right)\end{array}$ & $\begin{array}{c}\text { Sample } \\
\text { volume } \\
(\mathrm{mL})\end{array}$ \\
\hline LEW & 0 & 0.0 & 0.00 & 0 & -- \\
\hline $20 A$ & 36 & 3.2 & 0.36 & 26 & 810 \\
\hline $20 B$ & 36 & 3.2 & 0.36 & -- & 780 \\
\hline $19 A$ & 45 & 3.1 & 0.34 & 18 & 900 \\
\hline $19 B$ & 45 & 3.1 & 0.34 & -- & 670 \\
\hline $18 \mathrm{~A}$ & 70 & 3.1 & 0.36 & 19 & 780 \\
\hline $18 \mathrm{~B}$ & 70 & 3.1 & 0.36 & -- & 870 \\
\hline $17 \mathrm{~A}$ & 79 & 3.1 & 0.42 & 12 & 1080 \\
\hline $17 \mathrm{~B}$ & 79 & 3.1 & 0.42 & -- & 1050 \\
\hline $16 \mathrm{~A}$ & 88 & 2.9 & 0.42 & 18 & 880 \\
\hline $16 \mathrm{~B}$ & 88 & 2.9 & 0.42 & -- & 950 \\
\hline $15 A$ & 108 & 3.4 & 0.45 & 22 & 1120 \\
\hline $15 B$ & 108 & 3.4 & 0.45 & -- & 1630 \\
\hline $14 \mathrm{~A}$ & 117 & 3.2 & 0.46 & 20 & 1250 \\
\hline $14 \mathrm{~B}$ & 117 & 3.2 & 0.46 & -- & 1150 \\
\hline $13 A$ & 13.5 & 3.5 & 0.52 & 23 & 1520 \\
\hline $13 B$ & 135 & 3.5 & 0.52 & -- & 1200 \\
\hline $12 \mathrm{~A}$ & 142 & 4.0 & 0.57 & 29 & 1890 \\
\hline $12 B$ & 142 & 4.0 & 0.57 & -- & 2220 \\
\hline $11 \mathrm{~A}$ & 160 & 4.5 & 0.56 & 40 & 1770 \\
\hline $11 \mathrm{~B}$ & 160 & 4.5 & 0.56 & -- & 2000 \\
\hline $10 \mathrm{~A}$ & 174 & 4.4 & 0.63 & 41 & 2570 \\
\hline $10 \mathrm{~B}$ & 174 & 4.4 & 0.63 & -- & 2390 \\
\hline 09A & 190 & 4.5 & 0.69 & 49 & 2910 \\
\hline 09B & 190 & 4.5 & 0.69 & -- & 3010 \\
\hline $08 \mathrm{~A}$ & 205 & 4.6 & 0.70 & 47 & 2680 \\
\hline 08B & 205 & 4.6 & 0.70 & -- & 3020 \\
\hline $07 A$ & 219 & 4.9 & 0.72 & 51 & 3060 \\
\hline $07 \mathrm{~B}$ & 219 & 4.9 & 0.72 & -- & 3090 \\
\hline $06 \mathrm{~A}$ & 234 & 5.1 & 0.76 & 46 & 3430 \\
\hline 06B & 234 & 5.1 & 0.76 & -- & 3820 \\
\hline $05 A$ & 243 & 5.0 & 0.72 & 43 & 3610 \\
\hline $05 B$ & 243 & 5.0 & 0.72 & -- & 4010 \\
\hline $04 \mathrm{~A}$ & 258 & 5.6 & 0.72 & 55 & 3600 \\
\hline $04 \mathrm{~B}$ & 258 & 5.6 & 0.72 & -- & 3340 \\
\hline
\end{tabular}


STATION: Arkansas River at Mile 55.9, Ark.

$08-01-87$ (continued)

\begin{tabular}{cccccc}
$\begin{array}{c}\text { Verti- } \\
\text { cal }\end{array}$ & $\begin{array}{c}\text { Distance } \\
\text { from } \\
\text { LEW } \\
(\mathrm{m})\end{array}$ & Depth & $\begin{array}{c}\text { Mean } \\
\text { velocity }\end{array}$ & Discharge & $\begin{array}{c}\text { Sample } \\
\text { volume }\end{array}$ \\
& & $(\mathrm{m})$ & $(\mathrm{m} / \mathrm{s})$ & $\left(\mathrm{m}^{3} / \mathrm{s}\right)$ & $(\mathrm{mL})$ \\
\hline & & & & & \\
03A & 270 & 5.9 & 0.76 & 79 & 3720 \\
03B & 270 & 5.9 & 0.76 & -- & 3890 \\
02A & 293 & 6.0 & 0.73 & 68 & 4130 \\
02B & 293 & 6.0 & 0.73 & -- & 4490 \\
01A & 301 & 6.4 & 0.73 & 47 & 4420 \\
01B & 301 & 6.4 & 0.73 & -- & 3760 \\
REW & 313 & 0.0 & 0.00 & 0 & --
\end{tabular}

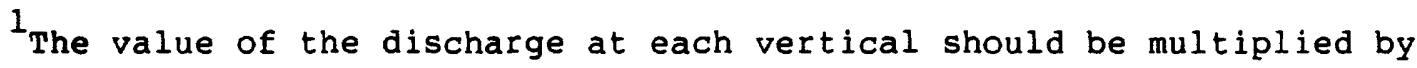
1.05 to give the correct discharge. See text under water Discharge Measurement for explanation. 


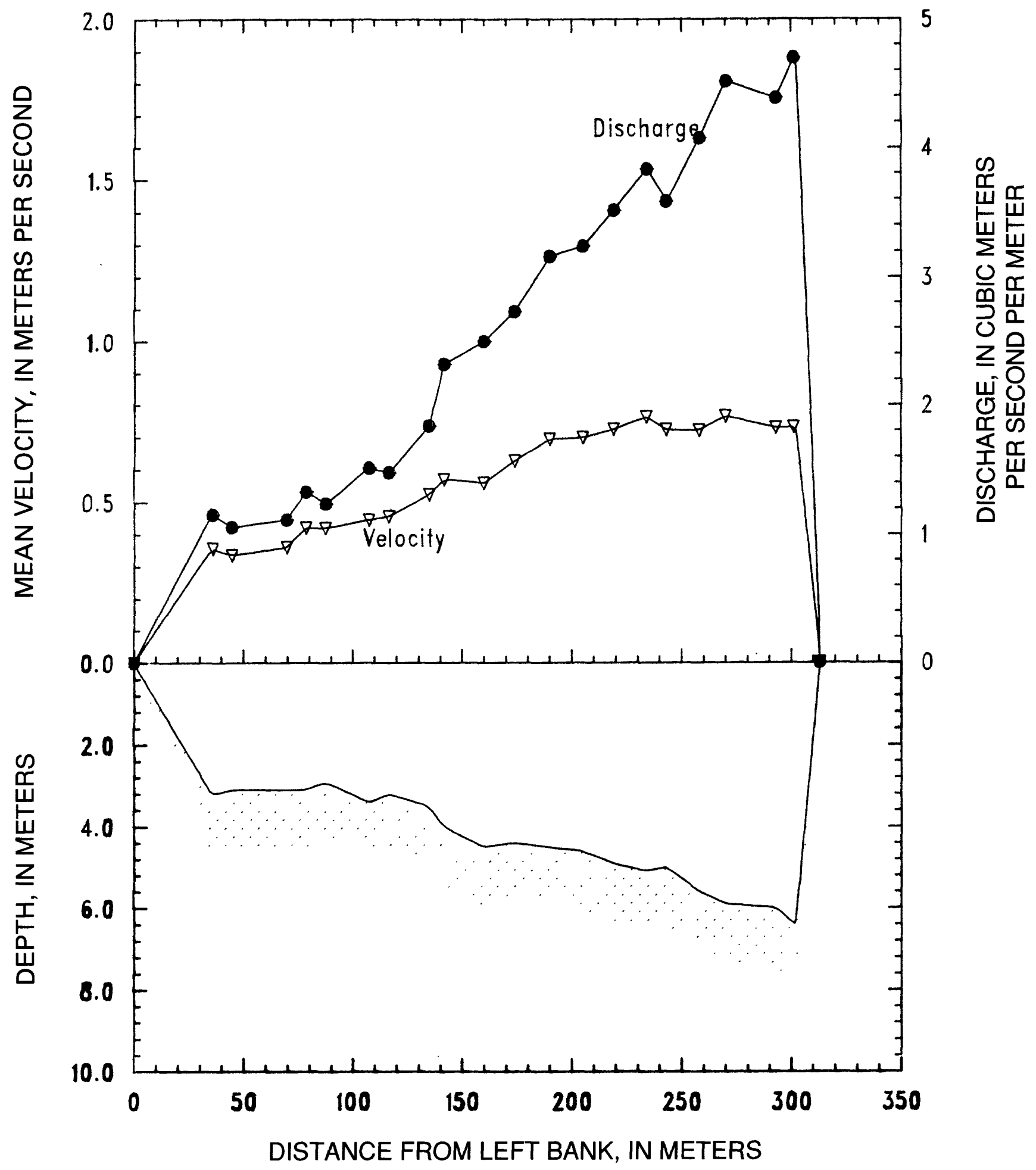

Figure 19. Arkansas River at Mile 55.9, Ark. on August 1, 1987. 
STATION: Mississippi River above Arkansas City, Ark. PARTY: Black, Moody, Cranston, and Stevens 08-02-87 STARTING GAGE HEIGHT: -- ENDING GAGE METER: SOLID CUP SUSP. Bag sampler and 200-1b weight

METER No: P8308282 DATE RATED: 11-04-87

WATER TEMP: $\quad 31.0^{\circ} \mathrm{C}$ at vertical $5 \mathrm{~A}$, and $30.9^{\circ} \mathrm{C}$ at vertical $17 \mathrm{~A}$. REMARKS: Transit rate was $8 \mathrm{~cm} / \mathrm{s}_{3}$ and nozzle was $3 / 16$ inch.

The total discharge was $7340 \mathrm{~m}^{3} / \mathrm{s}$.

\begin{tabular}{|c|c|c|c|c|c|}
\hline $\begin{array}{c}\text { Verti- } \\
\text { cal }\end{array}$ & $\begin{array}{c}\text { Distance } \\
\text { from } \\
\text { LEW } \\
\text { (m) }\end{array}$ & Depth & $\begin{array}{l}\text { Mean } \\
\text { velocity } \\
(\mathrm{m} / \mathrm{s})\end{array}$ & $\begin{array}{c}\text { Discharge } \\
\left(\mathrm{m}^{3} / \mathrm{s}\right)\end{array}$ & $\begin{array}{c}\text { Sample } \\
\text { volume } \\
\text { (mL) }\end{array}$ \\
\hline LEW & 0 & 0.0 & 0.00 & 0 & -- \\
\hline $30 \mathrm{~B}$ & 23 & 3.0 & 0.42 & 38 & 370 \\
\hline $29 A$ & 60 & 6.2 & 0.46 & 78 & 830 \\
\hline $28 B$ & 78 & 7.5 & 0.52 & 96 & 1210 \\
\hline $27 A$ & 109 & 10.4 & 0.55 & 160 & 1540 \\
\hline $26 B$ & 134 & 12.1 & 0.58 & 143 & 2280 \\
\hline $25 A$ & 150 & 12.9 & 0.64 & 194 & 3080 \\
\hline $24 B$ & 181 & 14.2 & 0.67 & 337 & 3340 \\
\hline $23 A$ & 221 & 14.6 & 0.71 & 353 & 3480 \\
\hline $22 B$ & 249 & 15.7 & 0.81 & 322 & 4910 \\
\hline $2 I A$ & 272 & 15.2 & 0.82 & 349 & 3210 \\
\hline $20 B$ & 305 & 15.5 & 0.91 & 473 & 5630 \\
\hline $19 \mathrm{~A}$ & 339 & 14.9 & 0.85 & 342 & 4530 \\
\hline $18 \mathrm{~B}$ & 359 & 15.5 & 0.93 & 382 & 4820 \\
\hline $17 \mathrm{~A}$ & 392 & 15.1 & 0.94 & 384 & 5260 \\
\hline $16 \mathrm{~B}$ & 413 & 15.2 & 0.90 & 351 & 5260 \\
\hline $15 \mathrm{~A}$ & 443 & 14.8 & 0.94 & 354 & 4900 \\
\hline $14 \mathrm{~B}$ & 464 & 14.3 & 0.88 & 297 & 4040 \\
\hline $13 \mathrm{~A}$ & 490 & 14.0 & 0.84 & 345 & 4130 \\
\hline $12 \mathrm{~B}$ & 523 & 12.5 & 0.94 & 364 & 4560 \\
\hline $11 \mathrm{~A}$ & 552 & 11.7 & 0.86 & 293 & 2980 \\
\hline $10 \mathrm{~B}$ & 581 & 11.4 & 0.85 & 218 & 3760 \\
\hline $09 \mathrm{~A}$ & 597 & 11.4 & 0.88 & 246 & 2880 \\
\hline $08 \mathrm{~B}$ & 630 & 11.1 & 0.71 & 237 & 2240 \\
\hline $07 \mathrm{~A}$ & 657 & 10.4 & 0.78 & 215 & 2830 \\
\hline $06 \mathrm{~B}$ & 683 & 10.1 & 0.72 & 182 & 1800 \\
\hline $05 \mathrm{~A}$ & 707 & 9.9 & 0.59 & 140 & 1500 \\
\hline $04 B$ & 731 & 10.0 & 0.60 & 178 & 1980 \\
\hline $03 \mathrm{~A}$ & 766 & 9.5 & 0.43 & 124 & 1040 \\
\hline O2B & 792 & 9.0 & 0.37 & 100 & 840 \\
\hline $01 \mathrm{~A}$ & 826 & 5.0 & 0.33 & 48 & 390 \\
\hline REW & 850 & 0.0 & 0.00 & 0 & -- \\
\hline
\end{tabular}

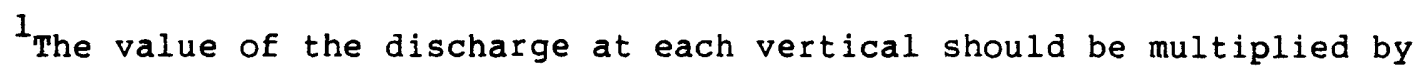
1.04 to give the correct discharge. See text under water Discharge Measurement for explanation. 


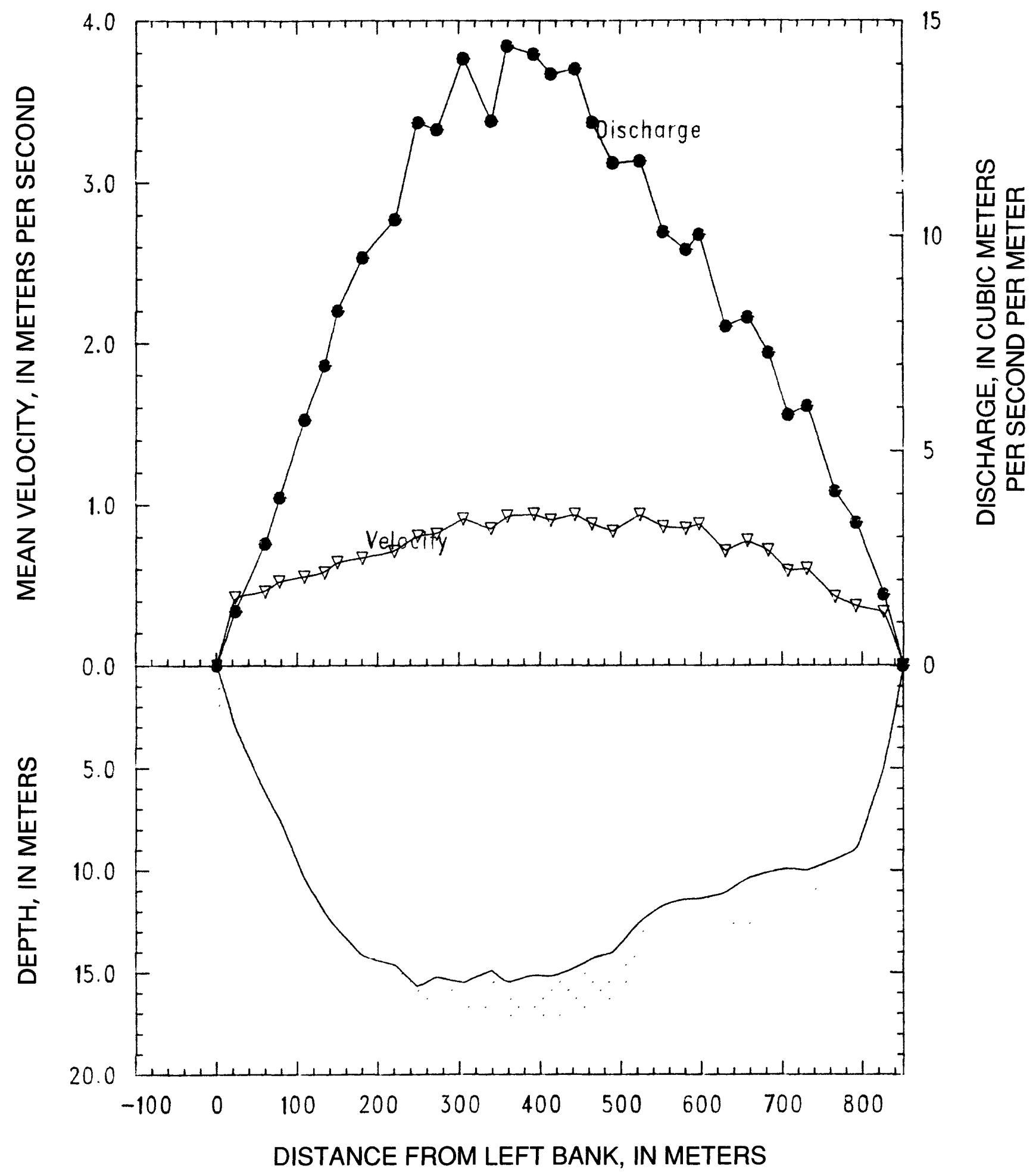

Figure 20. Mississippi River above Arkansas City, Ark. on August 2, 1987. 
STATION: Mississippi River below Vicksburg, Miss.

PARTY: Black, Moody, Cranston, and Stevens

METER: SOLID CUP

STARTING GAGE HEIGHT: $8.05 \mathrm{ft}$

ENDING GAGE HEIGHT: --

SUSP. Bag sampler and 200-1b weight

METER NO: P8308282 DATE RATED: 11-04-87

WATER TEMP: no measurement

REMARKS: Transit rate was $8 \mathrm{~cm} / \mathrm{s}_{3}$ and the nozzle was $3 / 16$ inch.

The total discharge was $7600 \mathrm{~m}^{3} / \mathrm{s}$.

\begin{tabular}{|c|c|c|c|c|c|}
\hline $\begin{array}{c}\text { Verti- } \\
\text { cal }\end{array}$ & $\begin{array}{c}\text { Distance } \\
\text { Erom } \\
\text { LEW } \\
\text { (m) }\end{array}$ & Depth & $\begin{array}{c}\text { Mean } \\
\text { velocity } \\
(\mathrm{m} / \mathrm{s})\end{array}$ & $\begin{array}{c}\text { Discharge } \\
\\
\left(\mathrm{m}^{3} / \mathrm{s}\right)\end{array}$ & $\begin{array}{l}\text { Sample } \\
\text { volume } \\
\text { (mL) }\end{array}$ \\
\hline LEW & 0 & 0.0 & 0.00 & 0 & -- \\
\hline $36 \mathrm{~B}$ & 21 & 8.5 & 0.46 & 131 & 890 \\
\hline $35 A$ & 67 & 13.6 & 1.05 & 641 & 3460 \\
\hline $34 \mathrm{~B}$ & 111 & 13.1 & 1.15 & 564 & 4880 \\
\hline $33 A$ & 142 & 12.3 & 1.17 & 346 & 3190 \\
\hline $32 \mathrm{~B}$ & 159 & 11.7 & 1.15 & 316 & 3680 \\
\hline $31 A$ & 189 & 11.4 & 1.19 & 419 & 4040 \\
\hline $30 \mathrm{~B}$ & 221 & 10.8 & 1.10 & 382 & 4020 \\
\hline $29 A$ & 253 & 10.5 & 1.07 & 327 & 3790 \\
\hline $28 B$ & 279 & 9.5 & 1.15 & 321 & 3360 \\
\hline $27 A$ & 312 & 9.7 & 1.09 & 296 & 3720 \\
\hline $26 B$ & 335 & 9.0 & 1.13 & 310 & 2730 \\
\hline $25 A$ & 373 & 8.7 & 1.14 & 337 & 3270 \\
\hline $24 B$ & 403 & 8.7 & 0.91 & 202 & 3790 \\
\hline $23 A$ & 424 & 8.8 & 1.00 & 273 & 3800 \\
\hline $22 B$ & 465 & 8.7 & 0.93 & 263 & 4360 \\
\hline $21 \mathrm{~A}$ & 489 & 8.8 & 1.17 & 292 & 2960 \\
\hline $20 B$ & 522 & 8.1 & 1.02 & 289 & 3340 \\
\hline $19 A$ & 559 & 8.0 & 0.91 & 232 & 2820 \\
\hline $18 \mathrm{~B}$ & 586 & 8.1 & 0.88 & 215 & 3390 \\
\hline $17 \mathrm{~A}$ & 619 & 7.2 & 0.86 & 183 & 2880 \\
\hline $16 \mathrm{~B}$ & 645 & 7.7 & 0.80 & 164 & 2670 \\
\hline $15 \mathrm{~A}$ & 672 & 6.9 & 0.84 & 166 & 2500 \\
\hline $14 \mathrm{~B}$ & 702 & 6.7 & 0.87 & 199 & 2130 \\
\hline $13 \mathrm{~A}$ & 740 & 5.9 & 0.70 & 131 & 900 \\
\hline $12 \mathrm{~B}$ & 766 & 5.1 & 0.67 & 99 & 1230 \\
\hline $11 \mathrm{~A}$ & 798 & 5.2 & 0.57 & 90 & 880 \\
\hline $10 \mathrm{~B}$ & 827 & 4.0 & 0.67 & 82 & 950 \\
\hline $09 A$ & 859 & 3.3 & 0.60 & 63 & 690 \\
\hline $08 \mathrm{~B}$ & 891 & 3.1 & 0.55 & 53 & 510 \\
\hline $07 A$ & 920 & 2.8 & 0.52 & 42 & 500 \\
\hline $06 \mathrm{~B}$ & 949 & 2.8 & 0.48 & 39 & 600 \\
\hline $05 A$ & 978 & 2.1 & 0.44 & 27 & 440 \\
\hline $04 \mathrm{~B}$ & 1007 & 2.3 & 0.45 & 32 & 390 \\
\hline $03 A$ & 1041 & 2.2 & 0.32 & 24 & 360 \\
\hline O2B & 1073 & 2.7 & 0.30 & 24 & 300 \\
\hline $01 A$ & 1100 & 2.6 & 0.41 & 31 & 180 \\
\hline REW & 1131 & 0.0 & 0.00 & 0 & -- \\
\hline
\end{tabular}

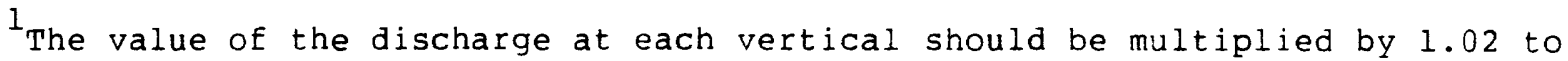
give the correct discharge. See text under Water Discharge Measurement. 


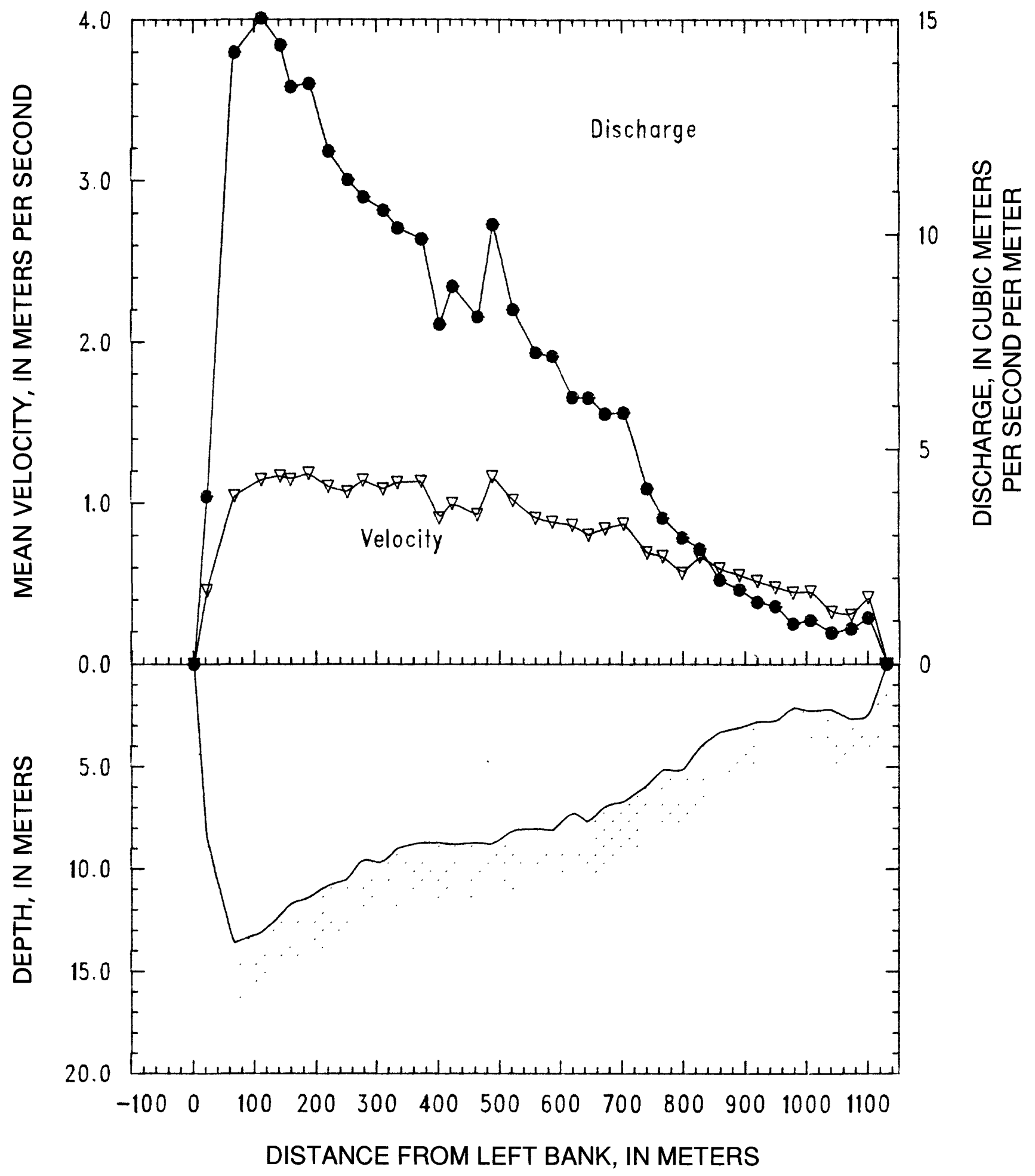

Figure 21. Mississippi River below Vicksburg, Miss. on August 4, 1987. 
STATION: Old River Outflow Channel near Knox Landing, La. 08-06-87 PARTY: Black, Cranston, Stevens, and Moody

METER: SOLID CUP STARTING GAGE HEIGHT: $2.83 \mathrm{ft}$ ENDING GAGE HEIGHT: --

SUSP. Bag sampler and $200-1 \mathrm{~b}$ weight

METER NO: P8308282 DATE RATED: 11-04-87

WATER TEMP: $30.9^{\circ} \mathrm{C}$

REMARKS: Transit rate was $10 \mathrm{~cm} / \mathrm{s}$ and the nozzle was $5 / 16$ inch.

Anchored at verticals $3,5,7,9$, and 11 where the open cup, Price $A A$

current meter was compared with the solid cup Price AA current meter.

\begin{tabular}{|c|c|c|c|c|c|}
\hline $\begin{array}{c}\text { Verti- } \\
\text { cal }\end{array}$ & $\begin{array}{c}\text { Distance } \\
\text { Erom } \\
\text { LEW } \\
\text { (m) }\end{array}$ & Depth & $\begin{array}{c}\text { Mean } \\
\text { velocity } \\
(\mathrm{m} / \mathrm{s})\end{array}$ & $\begin{array}{c}\text { Discharge } \\
\left(\mathrm{m}^{3} / \mathrm{s}\right)\end{array}$ & $\begin{array}{c}\text { Sample } \\
\text { volume } \\
(\mathrm{mL})\end{array}$ \\
\hline LEW & 0 & 0.0 & 0.00 & 0 & -- \\
\hline$x 07$ & 20 & 5.2 & 0.84 & 90 & -- \\
\hline $13 A$ & 41 & 5.5 & 1.14 & 142 & 5590 \\
\hline $13 \mathrm{~B}$ & 41 & 5.5 & 1.14 & - & 4770 \\
\hline $\mathrm{X} 06$ & 65 & 5.0 & 1.10 & 97 & -- \\
\hline $12 \mathrm{~B}$ & 76 & 4.9 & 1.11 & 41 & 4520 \\
\hline $12 \mathrm{~A}$ & 80 & 5.0 & 1.01 & 53 & 4720 \\
\hline X05 & 97 & 5.2 & 1.01 & 82 & -- \\
\hline $11 B$ & 111 & 5.3 & -- & -- & 4950 \\
\hline $11 A$ & 111 & 5.3 & 1.06 & 99 & 4860 \\
\hline $\mathrm{X} 04$ & 132 & 5.2 & 1.12 & 113 & -- \\
\hline $10 \mathrm{~B}$ & 150 & 5.0 & 0.94 & -- & 4280 \\
\hline $10 A$ & 150 & 5.0 & 0.94 & 130 & 3940 \\
\hline $09 B$ & 187 & 4.3 & -- & -- & 4100 \\
\hline O9A & 187 & 4.3 & 1.00 & 161 & 3800 \\
\hline $08 \mathrm{~B}$ & 225 & 4.2 & 0.88 & -- & 3600 \\
\hline $08 \mathrm{~A}$ & 225 & 4.2 & 0.88 & 101 & 2830 \\
\hline $\mathrm{X} 03$ & 242 & 4.0 & 0.94 & 69 & -- \\
\hline $07 B$ & 262 & 3.6 & -- & - & 3250 \\
\hline $07 A$ & 262 & 3.6 & 0.94 & 97 & 2710 \\
\hline $06 \mathrm{~B}$ & 299 & 3.8 & 0.80 & -- & 2660 \\
\hline $06 \mathrm{~A}$ & 299 & 3.8 & 0.80 & 108 & 2510 \\
\hline $05 B$ & 333 & 4.0 & -- & -- & 2610 \\
\hline $05 A$ & 333 & 4.0 & 0.68 & 83 & 2270 \\
\hline $04 \mathrm{R}$ & 360 & 3.4 & 0.78 & 38 & -- \\
\hline $04 \mathrm{~B}$ & 362 & 3.0 & 0.78 & 11 & 2730 \\
\hline $04 \mathrm{~A}$ & 369 & 3.0 & 0.92 & 50 & 2270 \\
\hline $03 B$ & 398 & 3.7 & -- & -- & 2530 \\
\hline $03 A$ & 398 & 3.7 & 0.77 & 67 & 2400 \\
\hline $\mathrm{X} 02$ & 416 & 4.1 & 0.91 & 80 & -- \\
\hline $02 \mathrm{~B}$ & 441 & 4.1 & 0.81 & 45 & 3380 \\
\hline $02 A$ & 443 & 4.3 & 0.90 & 74 & 3220 \\
\hline $0 I R$ & 479 & 4.1 & 0.94 & 71 & -- \\
\hline $\mathrm{X} 01$ & 480 & 3.7 & 0.98 & 4 & -- \\
\hline OIB & 481 & 4.1 & 0.95 & 2 & 3370 \\
\hline $01 \mathrm{~A}$ & 481 & 4.0 & 0.86 & 65 & 2840 \\
\hline REW & 519 & 0.0 & 0.00 & 0 & -- \\
\hline
\end{tabular}

${ }^{1}$ The value of the discharge at each vertical should be multiplied by 1.04 to give the correct discharge. See text under Water Discharge Measurement. 


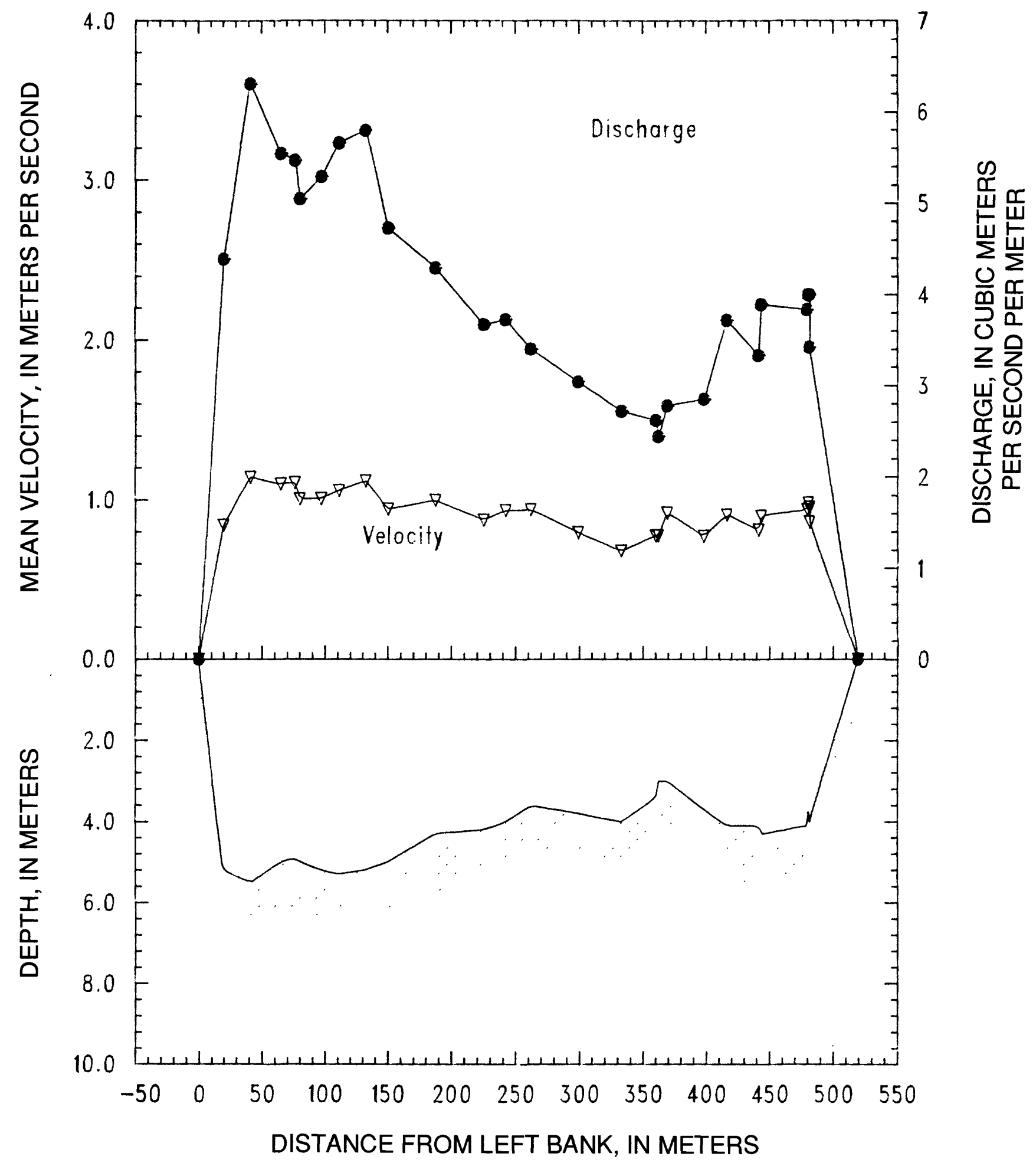

Figure 22. Old River Outflow Channel near Knox Landing, La. on August 6, 1987. 
STATION: Mississippi River near St. Francisville, La.

08-07-87

PARTY: Black, Cranston, Stevens, Rees, and Noyes

METER: OPEN CUP

STARTING GAGE HEIGHT: $2.65 \mathrm{ft}$ ENDING GAGE HEIGHT --

SUSP. Bag sampler and $200-1 \mathrm{~b}$ weight

METER No: W223906

DATE RATED: 11-06-87

WATER TEMP: no measurement

REMARKS: Transit rate was $12 \mathrm{~cm} / \mathrm{s}$ and the nozzle was $1 / 4$ inch.

The total discharge was $5950 \mathrm{~m}^{3} / \mathrm{s}$.

\begin{tabular}{|c|c|c|c|c|c|}
\hline $\begin{array}{c}\text { Verti- } \\
\text { cal }\end{array}$ & $\begin{array}{c}\text { Distance } \\
\text { from } \\
\text { LEW } \\
\text { (m) }\end{array}$ & Depth & $\begin{array}{c}\text { Mean } \\
\text { velocity } \\
(\mathrm{m} / \mathrm{s})\end{array}$ & $\begin{array}{l}\text { Discharge } \\
\left(\mathrm{m}^{3} / \mathrm{s}\right)\end{array}$ & $\begin{array}{c}\text { Sample } \\
\text { volume } \\
\text { (mL) }\end{array}$ \\
\hline LEW & 0 & 0.0 & 0.00 & 0 & -- \\
\hline $32 \mathrm{~B}$ & 16 & 4.0 & 0.35 & 32 & 580 \\
\hline $31 \mathrm{~A}$ & 46 & 5.0 & 0.33 & 48 & 440 \\
\hline $30 \mathrm{~B}$ & 74 & 4.9 & 0.42 & 65 & 520 \\
\hline $29 A$ & 109 & 5.9 & 0.49 & 89 & 910 \\
\hline $28 B$ & 135 & 5.9 & 0.69 & 120 & 1430 \\
\hline $27 A$ & 168 & 5.9 & 0.72 & 121 & 1160 \\
\hline $26 B$ & 192 & 6.4 & 0.69 & 97 & 1770 \\
\hline $25 A$ & 212 & 6.2 & 0.70 & 156 & 1740 \\
\hline $24 \mathrm{~B}$ & 264 & 6.9 & 0.78 & $=20$ & 1850 \\
\hline $23 A$ & 294 & 7.3 & 1.03 & $: 10$ & 2500 \\
\hline $22 B$ & 320 & 7.3 & 0.92 & 08 & 2940 \\
\hline $21 \mathrm{~A}$ & 356 & 7.3 & 0.91 & 212 & 2910 \\
\hline $20 B$ & 384 & 7.3 & 0.93 & 170 & 2810 \\
\hline $19 A$ & 406 & 7.2 & 1.00 & 217 & 2810 \\
\hline $18 \mathrm{~B}$ & 444 & 7.3 & 0.88 & 215 & 2850 \\
\hline $17 \mathrm{~A}$ & 473 & 7.3 & 1.01 & 250 & 2910 \\
\hline $16 \mathrm{~B}$ & 512 & 7.0 & 0.99 & $\therefore 04$ & 2930 \\
\hline $15 \mathrm{~A}$ & 532 & 7.5 & 1.02 & 241 & 2750 \\
\hline $14 \mathrm{~B}$ & 575 & 8.8 & 0.84 & 225 & 3000 \\
\hline $13 \mathrm{~A}$ & 593 & 8.4 & 0.95 & 204 & 3570 \\
\hline $12 \mathrm{~B}$ & 626 & 8.8 & 0.84 & 219 & 3060 \\
\hline $11 \mathrm{~A}$ & 652 & 10.1 & 0.93 & 292 & 3460 \\
\hline $10 \mathrm{~B}$ & 688 & 9.6 & 0.94 & 287 & 3570 \\
\hline $09 A$ & 716 & 9.4 & 0.93 & 258 & 3490 \\
\hline $08 \mathrm{~B}$ & 747 & 11.6 & 0.65 & 248 & 3720 \\
\hline $07 \mathrm{~A}$ & 782 & 9.9 & 0.99 & 279 & 5070 \\
\hline $06 \mathrm{~B}$ & 804 & 11.9 & 0.84 & 300 & 4280 \\
\hline $05 A$ & 842 & 10.1 & 1.00 & 358 & 3290 \\
\hline $04 \mathrm{~B}$ & 875 & 9.1 & 0.97 & 233 & 3760 \\
\hline $03 A$ & 895 & 10.2 & 0.87 & 244 & 3570 \\
\hline $02 \mathrm{~B}$ & 930 & 7.8 & 0.72 & 149 & 2680 \\
\hline OIA & 948 & 5.8 & 0.64 & 98 & 1630 \\
\hline REW & 983 & 0.0 & 0.00 & 0 & -- \\
\hline
\end{tabular}

${ }^{1}$ An open metal-cup Price AA current meter was used, at this section, which may measure 58 higher velocity than the solid polymer-cup Price AA current,

meter. The value of the discharge at each vertical should be multiplied by 0.95 to give the initial value in table 9 and then multiplied by 1.04 to correct for transit rate (see text under Water Discharge Measurement). 


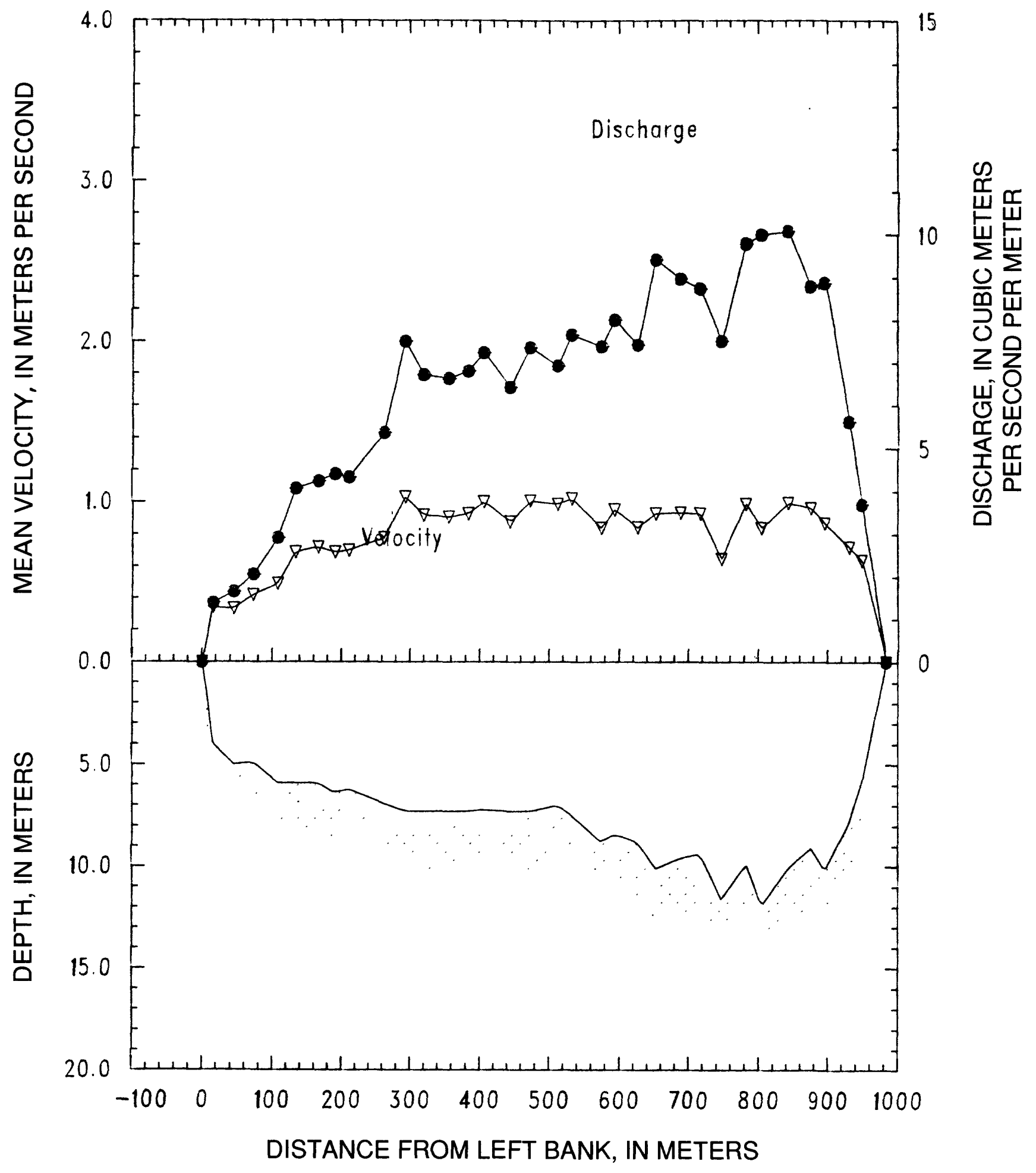

Figure 23. Mississippi R. near St. Francisville, La. on August 7, 1987. 
DATA LISTINGS

FOR

NOVEMBER 29 - DECEMBER 20, 1987

CRUISE 
STATION: Mississippi River near Winfield, Mo. PARTY: Simoneaux, Moody, and Stevens

STARTING GAGE HEIGHT: --

ENDING GAGE HEIGHT: -

METER: SOLID CUP

SUSP: Bag sampler and $150-1 \mathrm{~b}$ weight

METER NO: P8308282 DATE RATED: 4-7-88

REMARKS: Tripod was deployed near the REW. Tailwater at Dam 25 was $423.02 \mathrm{ft}$. Transit rate was $6 \mathrm{~cm} / \mathrm{s}$ and the nozzle was $1 / 4$ inch. The total discharge was $2000 \mathrm{~m}^{3} / \mathrm{s}$.

\begin{tabular}{|c|c|c|c|c|c|c|c|c|}
\hline $\begin{array}{c}\text { Verti- } \\
\text { cal }\end{array}$ & $\begin{array}{c}\text { Distance } \\
\text { from } \\
\text { IEW } \\
(\mathrm{m})\end{array}$ & $\begin{array}{l}\text { Depth } \\
(\mathrm{m})\end{array}$ & $\begin{array}{c}\text { Mean } \\
\text { velocity } \\
(\mathrm{m} / \mathrm{s})\end{array}$ & $\begin{array}{c}\text { Discharge } \\
\left(\mathrm{m}^{3} / \mathrm{s}\right)\end{array}$ & $\begin{array}{c}\text { Sample } \\
\text { volume } \\
(\mathrm{mL})\end{array}$ & $\begin{array}{l}\text { Temper- } \\
\text { ature } \\
\left({ }^{\circ} \mathrm{C}\right)\end{array}$ & $\mathrm{pH}$ & $\begin{array}{l}\text { Conductivity } \\
\text { (micro- } \\
\text { siemens/cm) }\end{array}$ \\
\hline LEW & 0 & 0.0 & 0.00 & 0 & -- & --- & -- & --- \\
\hline $29 A$ & 30 & 8.0 & 0.48 & 97 & 2270 & --- & -- & 413 \\
\hline $28 B$ & 51 & 9.0 & 0.78 & 133 & 5890 & --- & -- & 414 \\
\hline $27 A$ & 68 & 8.8 & 0.79 & 125 & 5680 & --- & -- & 414 \\
\hline $26 B$ & 87 & 9.0 & 0.82 & 144 & 5880 & --- & -- & 414 \\
\hline $25 \mathrm{~A}$ & 107 & 8.7 & 0.81 & 133 & 5600 & -- & -- & 415 \\
\hline $24 B$ & 125 & 8.5 & 0.79 & 91 & 4850 & --- & -- & 415 \\
\hline $23 A$ & 134 & 8.4 & 0.75 & 79 & 5400 & --- & -- & 414 \\
\hline $22 B$ & 150 & 8.3 & 0.76 & 105 & 5880 & --- & -- & 413 \\
\hline $21 A$ & 167 & 8.4 & 0.73 & 113 & 5290 & --- & -- & 414 \\
\hline $20 \mathrm{~B}$ & 187 & 8.2 & 0.73 & 110 & 4270 & --- & -- & 412 \\
\hline $19 A$ & 204 & 8.1 & 0.72 & 64 & 5020 & --- & -- & 414 \\
\hline $18 \mathrm{~B}$ & 209 & 7.9 & 0.69 & 76 & 4790 & --- & -- & 412 \\
\hline $17 \mathrm{~A}$ & 232 & 7.5 & 0.59 & 80 & 3690 & -- & -- & 412 \\
\hline $16 \mathrm{~B}$ & 245 & 7.4 & 0.60 & 76 & 3390 & --- & -- & 412 \\
\hline $15 \mathrm{R}$ & 266 & 7.0 & 0.56 & 65 & -- & --- & -- & --- \\
\hline $14 \mathrm{~B}$ & 278 & 6.8 & 0.53 & 26 & 3140 & --- & -- & 412 \\
\hline $15 \mathrm{~A}$ & 280 & 6.6 & 0.53 & 21 & 3120 & --- & -- & 413 \\
\hline $14 \mathrm{R}$ & 290 & 5.9 & 0.54 & 33 & -- & --- & -- & -- \\
\hline $13 \mathrm{~A}$ & 301 & 5.8 & 0.45 & 23 & 2150 & --- & -- & 413 \\
\hline $12 \mathrm{~B}$ & 308 & 5.7 & 0.50 & 43 & 1980 & --- & -- & 412 \\
\hline $11 A$ & 331 & 5.6 & 0.47 & 39 & 1700 & --- & -- & 412 \\
\hline $10 \mathrm{~B}$ & 338 & 5.4 & 0.46 & 50 & 2040 & --- & -- & 413 \\
\hline $09 A$ & 371 & 4.5 & 0.48 & 47 & 2000 & --- & -- & 413 \\
\hline 08B & 382 & 4.3 & 0.45 & 39 & 1280 & --- & -- & 413 \\
\hline $07 A$ & 411 & 4.1 & 0.43 & 29 & 1320 & --- & -- & 412 \\
\hline $06 B$ & 415 & 4.0 & 0.45 & 26 & 1360 & --- & -- & 413 \\
\hline $05 \mathrm{~A}$ & 440 & 3.5 & 0.41 & 26 & 850 & --- & -- & 413 \\
\hline $3 \mathrm{~B}$ & 451 & 3.4 & 0.46 & 24 & 1040 & --- & -- & 411 \\
\hline $03 A$ & 471 & 3.6 & 0.43 & 25 & 360 & --- & -- & 413 \\
\hline $02 \mathrm{~B}$ & 483 & 4.3 & 0.43 & 20 & 720 & --- & -- & 418 \\
\hline $31 A$ & 493 & 4.3 & 0.44 & 34 & 520 & --- & -- & 413 \\
\hline REW & 519 & 0.0 & 0.00 & 0 & -- & -- & -- & --- \\
\hline
\end{tabular}

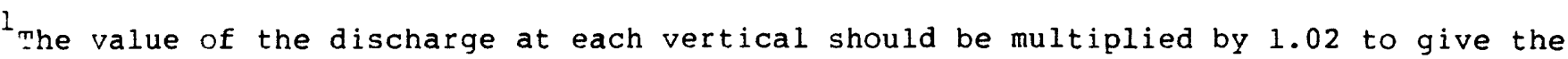
correct discharge. See text under Water Discharge Measurement for explanation. 


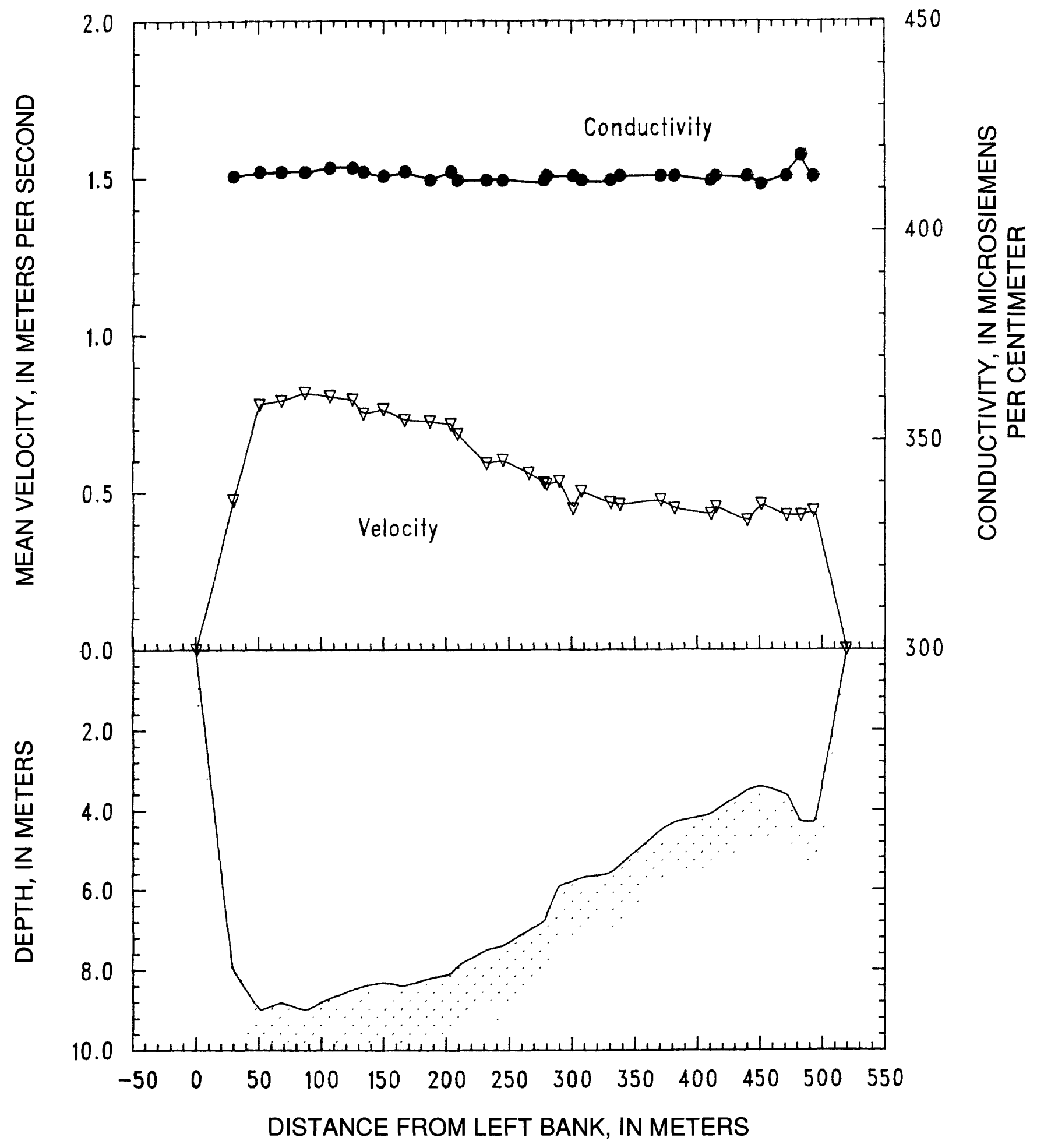

Figure 24. Mississippi River near Winfield, Mo. on November 30, 1987. 
STATION: Missouri River at St. Charles, Mo.

PARTY: Simoneaux, Moody, and Stevens

STARTING GAGE HEIGHT: --

ENDING GAGE HEIGHT: -

METER: $\quad \begin{array}{r}12-02-87 \\ \text { SOLID CUP }\end{array}$

SUSP. Bag sampler and 150-1b weight

METER No: P8308282 DATE RATED: 4-7-88

REMARKS: Tripod with current meter was deployed during the night. A dredge

was working upriver of the section. Transit, rate was $12 \mathrm{~cm} / \mathrm{s}$ and the nozzle was $1 / 4$ inch. The total discharge was $2750 \mathrm{~m}^{3} / \mathrm{s}$.

\begin{tabular}{|c|c|c|c|c|c|c|c|c|}
\hline $\begin{array}{l}\text { Verti- } \\
\text { cal }\end{array}$ & $\begin{array}{l}\text { Distance } \\
\text { from } \\
\text { LEW } \\
(\mathrm{m})\end{array}$ & Depth & $\begin{array}{c}\text { Mean } \\
\text { velocity } \\
(\mathrm{m} / \mathrm{s})\end{array}$ & $\begin{array}{c}\text { Discharge } \\
\left(\mathrm{m}^{3} / \mathrm{s}\right)\end{array}$ & $\begin{array}{c}\text { Sample } \\
\text { volume } \\
(m L)\end{array}$ & $\begin{array}{l}\text { Temper- } \\
\text { ature } \\
\left({ }^{\circ} \mathrm{C}\right)\end{array}$ & $\mathrm{pH}$ & $\begin{array}{l}\text { Conductivity } \\
\text { (micro- } \\
\text { siemens } / \mathrm{cm} \text { ) }\end{array}$ \\
\hline LEW & 0 & 0.0 & 0.00 & 0 & -- & --- & -- & -- \\
\hline $01 \mathrm{~A}$ & 13 & 5.0 & 0.93 & 84 & 2250 & 5.7 & 8.2 & 585 \\
\hline $02 \mathrm{~B}$ & 36 & 6.7 & 1.33 & 133 & 3630 & 6.0 & 8.2 & 587 \\
\hline $03 A$ & 43 & 6.7 & 1.21 & 85 & 3660 & 5.7 & 8.2 & 585 \\
\hline $04 \mathrm{~B}$ & 57 & 6.6 & 1.31 & 117 & 4200 & 5.7 & 8.2 & 583 \\
\hline $05 A$ & 70 & 6.5 & 1.38 & 121 & 3990 & 5.7 & 8.2 & 580 \\
\hline $06 \mathrm{~B}$ & 84 & 6.5 & 1.51 & 142 & 4650 & 5.7 & 8.2 & 577 \\
\hline 07A & 99 & 5.9 & 1.56 & 130 & 4390 & 5.4 & 8.2 & 581 \\
\hline $08 \mathrm{~B}$ & 112 & 5.5 & 1.61 & 116 & 4910 & 5.5 & 8.2 & 578 \\
\hline 09A & 125 & 5.6 & 1.66 & 126 & 3970 & 5.7 & 8.2 & 578 \\
\hline $10 \mathrm{~B}$ & 139 & 5.2 & 1.69 & 159 & 5020 & 5.7 & 8.3 & 578 \\
\hline $11 \mathrm{~A}$ & 161 & 5.4 & 1.68 & 118 & 4200 & 5.7 & 8.2 & 575 \\
\hline $12 \mathrm{~B}$ & 165 & 5.5 & 1.52 & 109 & 4000 & 5.7 & 8.2 & 576 \\
\hline $13 A$ & 187 & 5.0 & 1.44 & 105 & 4090 & 5.9 & 8.1 & 573 \\
\hline $14 \mathrm{~B}$ & 194 & 5.7 & 1.69 & 86 & 4360 & 6.3 & 8.2 & 576 \\
\hline $15 A$ & 205 & 5.4 & 1.53 & 132 & 3700 & 6.1 & 8.2 & 574 \\
\hline $16 \mathrm{~B}$ & 226 & 4.7 & 1.30 & 95 & 3840 & 6.2 & 8.2 & 576 \\
\hline $17 \mathrm{~A}$ & 236 & 4.8 & 1.45 & 101 & 4200 & 6.1 & 8.2 & 573 \\
\hline $18 \mathrm{~B}$ & 255 & 5.3 & 1.30 & 104 & 3670 & 6.4 & 8.2 & 572 \\
\hline $19 \mathrm{~A}$ & 266 & 5.8 & 1.35 & 95 & 3660 & 6.4 & 8.2 & 572 \\
\hline $20 \mathrm{R}$ & 274 & 5.9 & 1.36 & 37 & - & -- & -- & -- \\
\hline $20 \mathrm{~B}$ & 279 & 6.1 & 1.43 & 34 & 4610 & 6.3 & 8.2 & 575 \\
\hline $21 \mathrm{~A}$ & 288 & 5.9 & 1.34 & 130 & 4090 & 6.4 & 8.2 & 573 \\
\hline $22 \mathrm{~B}$ & 307 & 5.9 & 1.22 & 122 & 3830 & 6.4 & 8.2 & 574 \\
\hline $23 A$ & 322 & 5.9 & 1.20 & 92 & 2450 & 6.3 & 8.2 & 573 \\
\hline $24 B$ & 333 & 5.9 & 1.09 & 90 & 3080 & 6.4 & 8.2 & 574 \\
\hline $25 \mathrm{~A}$ & 350 & 5.2 & 0.56 & 44 & 930 & 6.4 & 8.2 & 574 \\
\hline $26 \mathrm{~B}$ & 363 & 3.3 & 0.02 & 1 & 230 & 6.4 & 8.2 & 575 \\
\hline $28 \mathrm{~B}$ & 373 & 3.2 & 0.15 & 4 & 240 & 6.4 & 8.2 & 577 \\
\hline $27 A$ & 381 & 4.8 & 0.08 & 6 & 210 & 6.2 & 8.2 & 575 \\
\hline$X 01$ & 408 & 5.6 & 0.19 & 25 & -- & --- & -- & --- \\
\hline REW & 428 & 0.0 & 0.00 & 0 & -- & -- & -- & -- \\
\hline
\end{tabular}

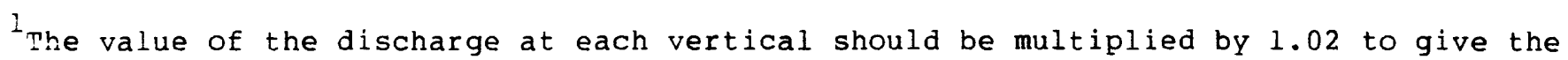
correct discharge. See text under Water Discharge Measurement for explanation. 


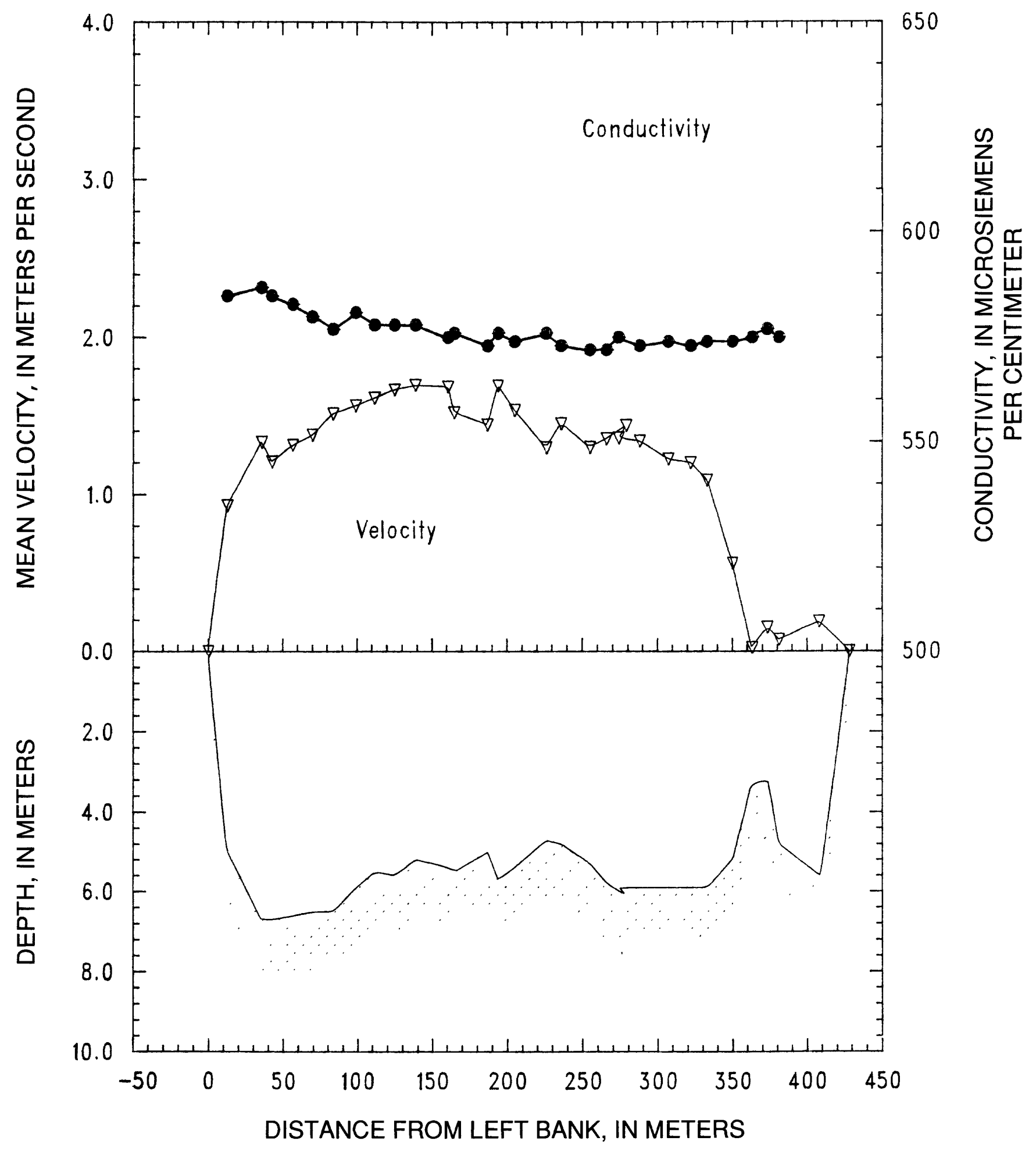

Figure 25. Missouri River at St. Charles, Mo. on December 2, 1987. 
STATION: Mississippi River at St. Louis, Mo. PARTY: Simoneaux, Moody, and Stevens STARTING GAGE HEIGHT: $10.65 \mathrm{ft}$.

SUSP: Bag sampler and 150-1b weight.

METER NO: P8308282 DATE RATED: 4-7-88

REMARKS: Very strong winds! Transit rate, was $16 \mathrm{~cm} / \mathrm{s}$ and the nozzle was i/4 inch. The total discharge was $5230 \mathrm{~m}^{3} / \mathrm{s}$.

\begin{tabular}{|c|c|c|c|c|c|c|c|c|}
\hline $\begin{array}{l}\text { Verti- } \\
\text { cal }\end{array}$ & $\begin{array}{l}\text { Distance } \\
\text { from } \\
\text { LEW } \\
(\mathrm{m})\end{array}$ & Depth & $\begin{array}{l}\text { Mean } \\
\text { velocity } \\
(\mathrm{m} / \mathrm{s})\end{array}$ & $\begin{array}{c}\text { Discharge } \\
\left(\mathrm{m}^{3} / \mathrm{s}\right)\end{array}$ & $\begin{array}{l}\text { Sample } \\
\text { volume } \\
(\mathrm{mL})\end{array}$ & $\begin{array}{l}\text { Temper- } \\
\text { ature } \\
\left({ }^{\circ} \mathrm{C}\right)\end{array}$ & $\mathrm{pH}$ & $\begin{array}{l}\text { Conductivity } \\
\text { (micro- } \\
\text { siemens/cm) }\end{array}$ \\
\hline LEW & 0 & 0.0 & 0.00 & 0 & -- & --- & -- & -- \\
\hline $01 \mathrm{~A}$ & 52 & 11.6 & 1.23 & 485 & 4850 & 5.5 & 8.6 & 473 \\
\hline $02 B$ & 68 & 11.1 & 1.43 & 168 & 5180 & 5.4 & 8.6 & 471 \\
\hline $03 A$ & 73 & 10.9 & 1.40 & 215 & 5240 & 5.5 & 8.6 & 473 \\
\hline $04 \mathrm{~B}$ & 96 & 10.5 & 1.57 & 387 & 5940 & 5.4 & 8.6 & 472 \\
\hline $35 \mathrm{~A}$ & 120 & 10.9 & 1.54 & 294 & 5600 & 5.5 & 8.6 & 473 \\
\hline $06 \mathrm{~B}$ & 131 & 11.3 & 1.43 & 122 & 5080 & 5.5 & 8.6 & 472 \\
\hline $07 \mathrm{~A}$ & 135 & 10.5 & 1.38 & 138 & 4600 & 5.5 & 8.5 & 477 \\
\hline $08 B$ & 150 & 10.0 & 1.52 & 273 & 5680 & 5.7 & 8.5 & 481 \\
\hline $09 A$ & 171 & 9.3 & 1.47 & 211 & 4680 & 5.7 & 8.5 & 488 \\
\hline $10 B$ & 181 & 9.6 & 1.55 & 216 & 4680 & 5.6 & 8.5 & 489 \\
\hline $11 \mathrm{~A}$ & 200 & 9.5 & 1.54 & 197 & 4520 & 5.8 & 8.5 & 496 \\
\hline $12 \mathrm{~B}$ & 208 & 9.6 & 1.41 & 183 & 4450 & 5.8 & 8.4 & 494 \\
\hline $13 \mathrm{~A}$ & 227 & 8.7 & 1.65 & 186 & 4770 & 6.2 & 8.4 & 501 \\
\hline $14 \mathrm{~B}$ & 234 & 8.4 & 1.65 & 146 & 5120 & 6.5 & 8.4 & 512 \\
\hline $15 \mathrm{~A}$ & 248 & 7.7 & 1.55 & 216 & 4250 & 7.1 & 8.3 & 521 \\
\hline $16 \mathrm{~B}$ & 270 & 7.2 & 1.70 & 221 & 3890 & 6.8 & 8.4 & 514 \\
\hline $17 \mathrm{~A}$ & 284 & 7.3 & 1.40 & 188 & 3080 & 6.8 & 8.3 & 513 \\
\hline $18 \mathrm{~B}$ & 307 & 6.8 & 1.08 & 113 & 2600 & 6.7 & 8.3 & 527 \\
\hline $19 A$ & 315 & 7.7 & 1.26 & 102 & 3080 & 6.7 & 8.3 & 528 \\
\hline $20 B$ & 328 & 7.8 & 1.12 & 126 & 2970 & 6.9 & 8.0 & 529 \\
\hline $21 \mathrm{~A}$ & 344 & 7.8 & 1.11 & 125 & 2680 & 7.4 & 8.3 & 527 \\
\hline $22 B$ & 357 & 7.4 & 1.10 & 126 & 2330 & --- & -- & -- \\
\hline $23 \mathrm{~A}$ & 375 & 6.7 & 1.11 & 104 & 2580 & 7.4 & 8.0 & 538 \\
\hline $24 B$ & 385 & 7.5 & 0.89 & 97 & 2110 & 7.2 & 8.1 & 540 \\
\hline $25 \mathrm{~A}$ & 404 & 7.3 & 0.94 & 127 & 2290 & 7.2 & 8.1 & 538 \\
\hline $26 B$ & 422 & 7.2 & 0.93 & 111 & 2520 & 7.7 & 8.1 & 543 \\
\hline $27 \mathrm{~A}$ & 437 & 7.1 & 0.98 & 94 & 2220 & 7.1 & 8.1 & 540 \\
\hline $28 B$ & 449 & 7.3 & 0.93 & 111 & 2380 & 7.7 & 8.1 & 540 \\
\hline $29 A$ & 470 & 7.3 & 0.71 & 73 & 1670 & --- & -- & --- \\
\hline $30 \mathrm{~B}$ & 477 & 7.0 & 0.53 & 77 & 1060 & --- & -- & --- \\
\hline REW & 511 & 0.0 & 0.00 & 0 & -- & --- & -- & --- \\
\hline
\end{tabular}

12-03-87

METER : SOLID CUP

ENDING GAGE HEIGHT: $10.60 \mathrm{ft}$.
$2 / 4$ inch. The total discharge was $5230 \mathrm{~m} / \mathrm{s}$.

The value of the discharge at each vertical should be multiplied by 1.04 to give the correct discharge. See text under Water Discharge Measurement for explanation. 


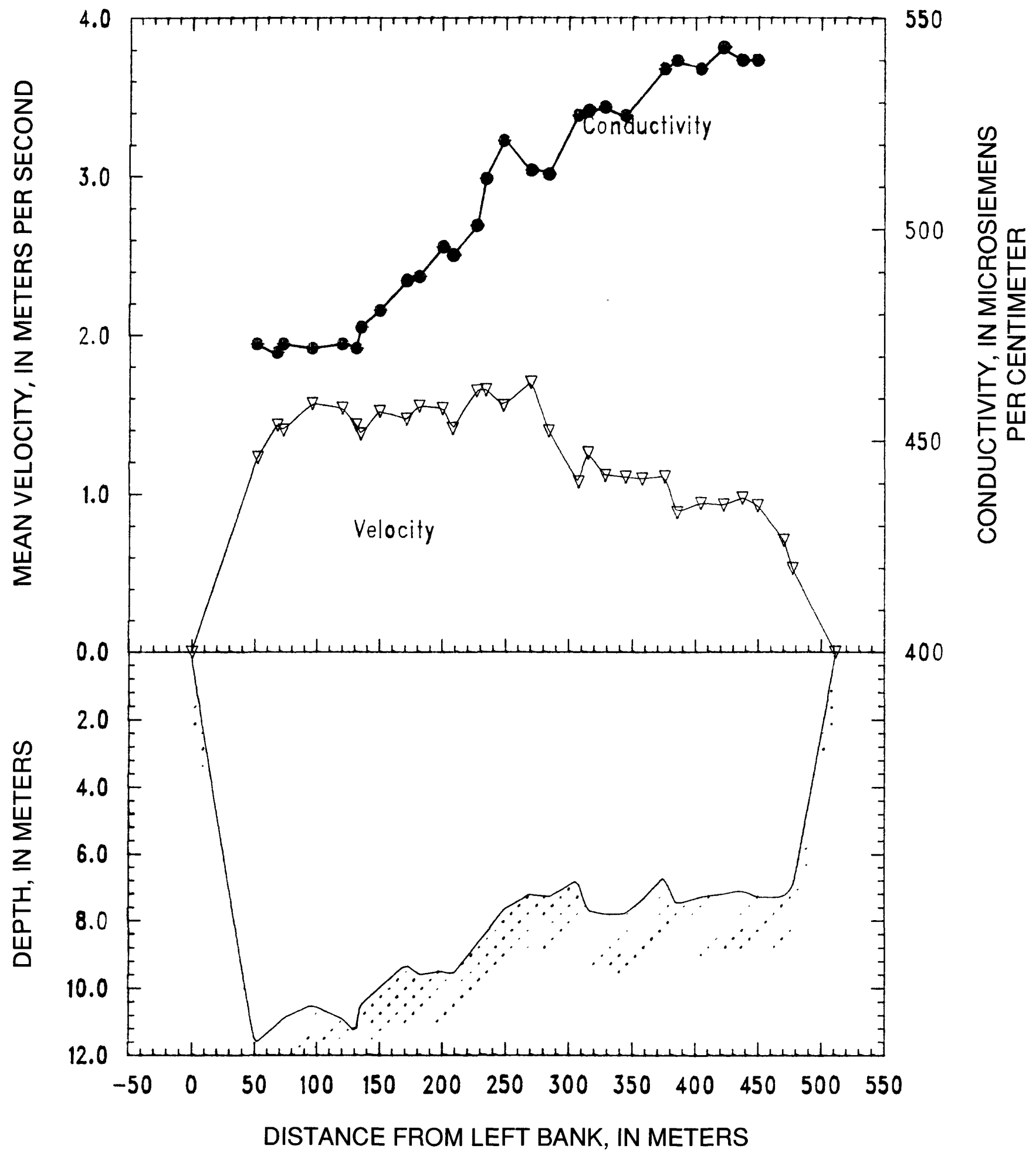

Figure 26. Mississippi River at St. Louis, Mo. on December 3, 1987. 
STATION: Mississippi River at Thebes, Ill.

PARTY: Black, Moody, and Stevens

$12-05-87$

STARTING GAGE HEIGHT: $16.4 \mathrm{ft}$.

METER :

SOLID CUP

SUSP: Bag sampler and 150-1b weight.

METER NO: P8308282 DATE RATED: 4-7-88

REMARKS: Transit rate was $18 \mathrm{~cm} / \mathrm{s}, 3$ and the nozzle was $1 / 4$ inch.

The total discharge was $4990 \mathrm{~m}^{3} / \mathrm{s}$.

\begin{tabular}{|c|c|c|c|c|c|c|c|c|}
\hline $\begin{array}{l}\text { Terti- } \\
\text { cal }\end{array}$ & $\begin{array}{l}\text { Distance } \\
\text { from } \\
\text { LEW } \\
\text { (m) }\end{array}$ & Depth & $\begin{array}{l}\text { Mean } \\
\text { velocity } \\
(\mathrm{m} / \mathrm{s})\end{array}$ & $\begin{array}{c}\text { Discharge } \\
\left(\mathrm{m}^{3} / \mathrm{s}\right)\end{array}$ & $\begin{array}{l}\text { Sample } \\
\text { volume } \\
\text { (mL) }\end{array}$ & $\begin{array}{l}\text { Temper- } \\
\text { ature } \\
\left({ }^{\circ} \mathrm{C}\right)\end{array}$ & $\mathrm{pH}$ & $\begin{array}{l}\text { Conductivity } \\
\text { (micro- } \\
\text { siemens/cm) }\end{array}$ \\
\hline LEW & 0 & 0.0 & 0.00 & 0 & -- & --- & -- & -- \\
\hline $01 \mathrm{~A}$ & 19 & 3.1 & 0.55 & 31 & 560 & 5.7 & 8.3 & 517 \\
\hline $02 B$ & 37 & 5.0 & 0.71 & 64 & 1140 & 6.4 & 8.3 & 517 \\
\hline $03 A$ & 55 & 8.1 & 0.82 & 119 & 1470 & 6.0 & 8.3 & 518 \\
\hline $04 \mathrm{~B}$ & 73 & 7.8 & 1.10 & 115 & 2520 & 5.9 & 8.2 & 516 \\
\hline $05 \mathrm{~A}$ & 82 & 7.7 & 1.20 & 167 & 2750 & 5.7 & 8.3 & 515 \\
\hline $06 \mathrm{~B}$ & 109 & 8.6 & 1.23 & 243 & 3650 & 4.7 & 8.3 & 512 \\
\hline $07 \mathrm{~A}$ & 128 & 8.5 & 1.59 & 216 & 3340 & 5.7 & 8.3 & 512 \\
\hline $08 \mathrm{~B}$ & 141 & 8.4 & 1.38 & 237 & 3780 & 5.7 & 8.3 & 514 \\
\hline O9A & 169 & 8.6 & 1.46 & 213 & 4160 & 5.6 & 8.3 & 515 \\
\hline $10 B$ & 175 & 8.4 & 1.41 & 172 & 3820 & 5.6 & 8.3 & 510 \\
\hline $11 \mathrm{~A}$ & 198 & 8.4 & 1.50 & 221 & 3760 & 5.6 & 8.3 & 515 \\
\hline$x 17$ & 210 & 8.6 & 1.55 & 93 & -- & -- & -- & --- \\
\hline $12 \mathrm{~B}$ & 212 & 8.8 & 1.55 & 130 & 3710 & 5.5 & 8.3 & 509 \\
\hline $\mathrm{x} 03$ & 229 & 8.8 & 1.41 & 119 & -- & --- & -- & -- \\
\hline $\mathrm{X} 16$ & 231 & 8.8 & 1.49 & 105 & -- & --- & -- & --- \\
\hline $13 \mathrm{~A}$ & 245 & 8.8 & 1.60 & 191 & 4150 & 5.5 & 8.3 & 510 \\
\hline $14 \mathrm{~B}$ & 258 & 8.6 & 1.52 & 144 & 3700 & 5.5 & 8.3 & 510 \\
\hline $15 \mathrm{~A}$ & 267 & 8.4 & 1.49 & 125 & 3730 & 5.7 & 8.4 & 514 \\
\hline X15 & 278 & 8.6 & 1.50 & 188 & -- & -- & -- & -- \\
\hline $16 \mathrm{~B}$ & 296 & 8.7 & 1.24 & 163 & 3000 & 5.9 & 8.4 & 514 \\
\hline $17 \mathrm{~A}$ & 308 & 8.1 & 1.36 & 121 & 3440 & 5.9 & 8.3 & 511 \\
\hline $\mathrm{X} 12$ & 318 & 8.1 & 1.50 & 133 & -- & --- & -- & -- \\
\hline $18 \mathrm{~B}$ & 330 & 8.1 & 1.33 & 97 & 3580 & 5.8 & 8.3 & 515 \\
\hline $\mathrm{X} 11$ & 336 & 7.9 & 1.34 & 106 & -- & -- & -- & -- \\
\hline $19 \mathrm{~A}$ & 350 & 7.8 & 1.37 & 112 & 3440 & 5.9 & 8.3 & 511 \\
\hline $20 \mathrm{~B}$ & 357 & 8.4 & 1.39 & 99 & 3040 & 5.8 & 8.2 & 508 \\
\hline X09 & 367 & 7.6 & 1.38 & 116 & -- & -- & -- & --- \\
\hline $21 \mathrm{~A}$ & 379 & 6.8 & 1.45 & 84 & 2980 & 5.8 & 8.2 & 507 \\
\hline $\mathrm{x} 08$ & 384 & 6.8 & 1.31 & 107 & -- & --- & -- & --- \\
\hline $22 \mathrm{~B}$ & 403 & 6.8 & 1.26 & 150 & 2570 & 5.8 & 8.3 & 509 \\
\hline $23 \mathrm{~A}$ & 419 & 6.1 & 1.23 & 127 & 2110 & 5.8 & 8.3 & 510 \\
\hline $24 B$ & 437 & 6.1 & 1.32 & 104 & 1930 & 5.8 & 8.3 & 512 \\
\hline $25 \mathrm{~A}$ & 445 & 6.4 & 1.27 & 130 & 2440 & 5.7 & 8.3 & 512 \\
\hline $26 \mathrm{~B}$ & 469 & 5.4 & 1.26 & 133 & 2130 & 5.8 & 8.3 & 508 \\
\hline $27 \mathrm{~A}$ & 484 & 5.0 & 1.27 & 74 & 2070 & 5.8 & 8.3 & 508 \\
\hline$\angle 3 B$ & 492 & 4.9 & 1.20 & 61 & 1790 & 5.8 & 8.3 & 507 \\
\hline $29 A$ & 505 & 4.9 & 1.29 & 117 & 1710 & 5.8 & 8.3 & 509 \\
\hline $30 \mathrm{~B}$ & 529 & 2.0 & 0.86 & 59 & 550 & 5.4 & 8.3 & 511 \\
\hline REW & 574 & 0.0 & 0.00 & 0 & -- & -- & -- & -- \\
\hline
\end{tabular}

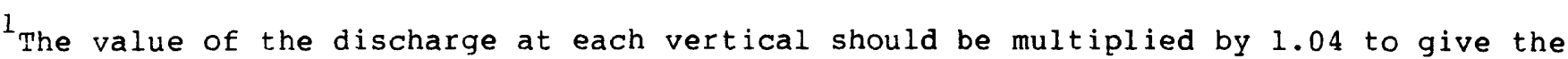
correct discharge. See text under Water Discharge Measurement for explanation. 


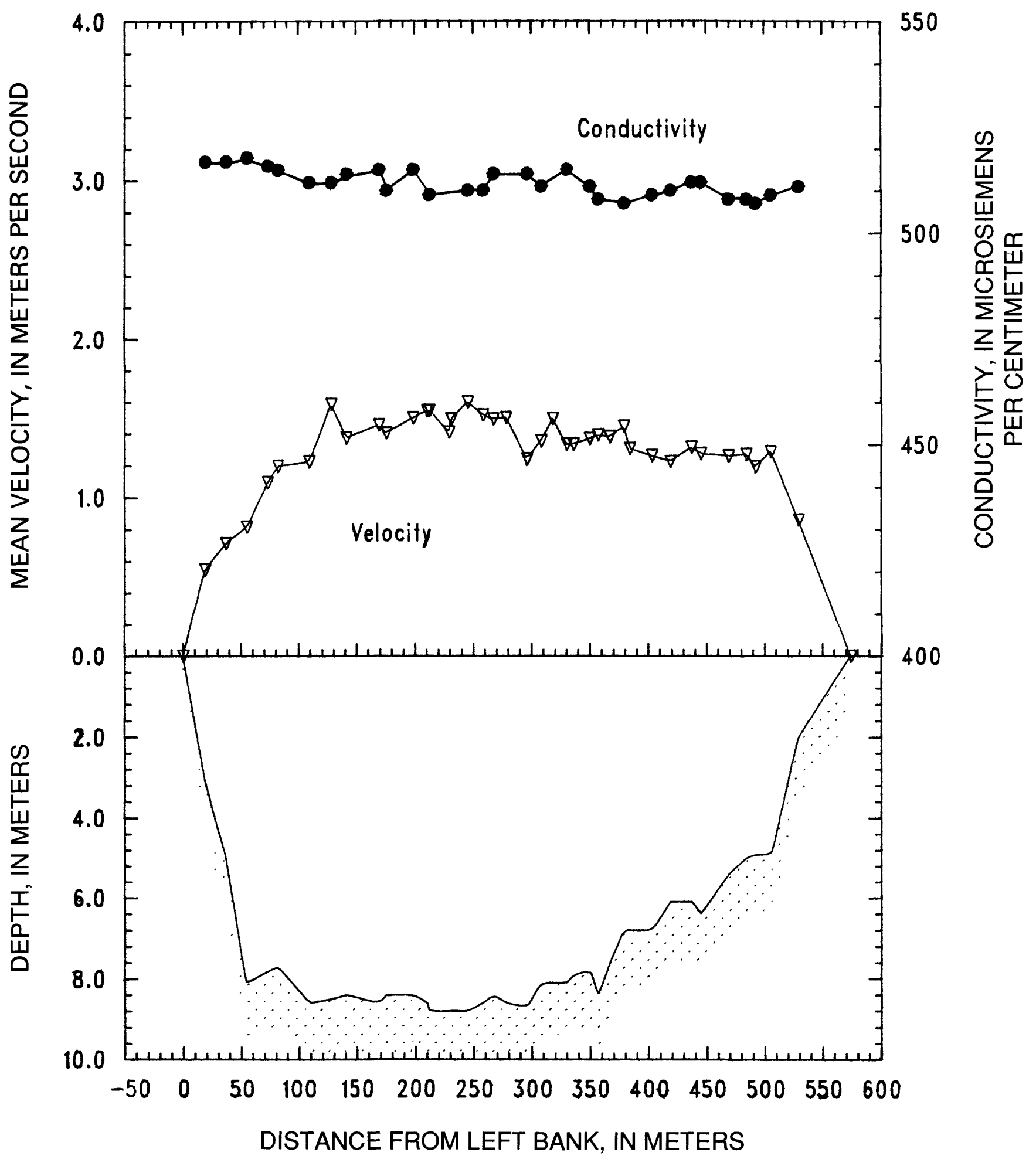

Figure 27. Mississippi River at Thebes, III. on December 5, 1987. 
STATION: Ohio River at Olmsted, Ill. $12-06-87$

PARTY: Black, Moody, and Stevens

METER : SOLID CUP

STARTING ARBITRARY GAGE HEIGHT: $1.00 \mathrm{~m}$ ENDING GAGE HEIGHT: $0.95 \mathrm{~m}$

SUSP: Bag sampler and 150-1b weight.

METER NO: P8308282 DATE RATED: 4-7-88

REMARKS: It rained off and on all day. Tripod was deployed near LEW in $6 \mathrm{~m}$ of water. Transit rate was $7 \mathrm{~cm} / \mathrm{s}$ and the nozzle was $5 / 16$ inch. Only upcast velocities are listed. The total discharge was $4200 \mathrm{~m} / \mathrm{s}$.

\begin{tabular}{|c|c|c|c|c|c|c|c|c|}
\hline $\begin{array}{c}\text { Verti- } \\
\text { cal }\end{array}$ & $\begin{array}{l}\text { Distance } \\
\text { from } \\
\text { LEW } \\
(\mathrm{m})\end{array}$ & Depth & $\begin{array}{l}\text { Mean } \\
\text { velocity } \\
(\mathrm{m} / \mathrm{s})\end{array}$ & $\begin{array}{l}\text { Discharge } \\
\left(\mathrm{m}^{3} / \mathrm{s}\right)\end{array}$ & $\begin{array}{c}\text { Sample } \\
\text { volume } \\
(m L)\end{array}$ & $\begin{array}{l}\text { Temper- } \\
\text { ature } \\
\left({ }^{\circ} \mathrm{C}\right)\end{array}$ & $\mathrm{pH}$ & $\begin{array}{l}\text { Conductivity } \\
\text { (micro- } \\
\text { siemens/cm) }\end{array}$ \\
\hline LEW & 0 & 0.0 & 0.00 & 0 & -- & -- & -- & -- \\
\hline $30 \mathrm{~B}$ & 32 & 2.9 & 0.31 & 27 & 740 & 10.2 & 8.1 & 338 \\
\hline $29 A$ & 61 & 3.2 & 0.21 & 22 & 610 & 10.4 & 8.1 & 341 \\
\hline $28 B$ & 97 & 3.8 & 0.34 & 46 & 490 & 10.1 & 8.1 & 343 \\
\hline $27 \mathrm{~A}$ & 133 & 4.8 & 0.27 & 36 & 810 & 9.4 & 8.0 & 345 \\
\hline $26 B$ & 153 & 5.1 & 0.33 & 45 & 1080 & 10.1 & 8.1 & 346 \\
\hline $25 \mathrm{~A}$ & 186 & 5.5 & 0.28 & 54 & 920 & 9.5 & 8.1 & 347 \\
\hline $24 B$ & 224 & 6.4 & 0.40 & 81 & 1340 & 9.2 & 8.1 & 351 \\
\hline $23 A$ & 249 & 7.1 & 0.43 & 86 & 1310 & 9.1 & 8.1 & 351 \\
\hline $22 B$ & 280 & 7.4 & 0.40 & 109 & 3370 & 8.7 & 8.2 & 348 \\
\hline $21 A$ & 323 & 8.3 & 0.44 & 139 & 2610 & 8.7 & 8.1 & 351 \\
\hline $20 B$ & 357 & 8.8 & 0.48 & 122 & 3790 & 8.3 & 8.2 & 352 \\
\hline $19 A$ & 381 & 9.0 & 0.49 & 105 & 2250 & -- & -- & 370 \\
\hline $18 \mathrm{~B}$ & 405 & 9.4 & 0.47 & 134 & 5370 & -- & -- & 360 \\
\hline $17 \mathrm{~A}$ & 442 & 9.9 & 0.54 & 181 & 4380 & --- & -- & 361 \\
\hline $16 \mathrm{~B}$ & 473 & 10.2 & 0.51 & 151 & 4310 & 8.6 & 8.1 & 390 \\
\hline $15 \mathrm{~A}$ & 500 & 9.9 & 0.60 & 176 & 3660 & 8.4 & 8.0 & 382 \\
\hline $14 \mathrm{~B}$ & 532 & 9.9 & 0.5 & 187 & 6030 & 8.7 & 8.0 & 397 \\
\hline $13 A$ & 565 & 9.8 & 0.61 & 201 & 3150 & 8.7 & 8.0 & 410 \\
\hline $12 \mathrm{~B}$ & 599 & 9.2 & 0.68 & 201 & 6400 & 8.6 & 8.1 & 410 \\
\hline$I I A$ & 629 & 8.1 & 0.84 & 208 & 6500 & 8.6 & 8.1 & 415 \\
\hline $10 B$ & 660 & 8.8 & 0.76 & 216 & 6050 & 8.7 & 8.1 & 425 \\
\hline $09 A$ & 693 & 9.2 & 0.68 & 176 & 6360 & 8.4 & 8.0 & 428 \\
\hline 08B & 716 & 9.5 & 0.92 & 253 & 6360 & 8.4 & 8.1 & 430 \\
\hline $07 A$ & 751 & 10.0 & 0.71 & 243 & 6410 & 8.3 & 8.0 & 432 \\
\hline $06 \mathrm{~B}$ & 784 & 9.6 & 0.65 & 222 & 6210 & 8.0 & 8.0 & 431 \\
\hline $05 A$ & 822 & 9.7 & 0.66 & 200 & 6210 & 8.5 & 8.1 & 435 \\
\hline $04 \mathrm{~B}$ & 846 & 9.9 & 0.59 & 166 & 6290 & 8.5 & 8.1 & 432 \\
\hline $03 A$ & 879 & 10.0 & 0.53 & 176 & 5450 & 8.5 & 8.1 & 432 \\
\hline $32 \mathrm{~B}$ & 912 & 10.3 & 0.50 & 154 & 5120 & 8.7 & 7.9 & 433 \\
\hline $01 A$ & 939 & 7.7 & 0.34 & 81 & 2090 & 8.7 & 8.1 & 432 \\
\hline REW & 974 & 0.0 & 0.00 & 0 & -- & --- & -- & --- \\
\hline
\end{tabular}




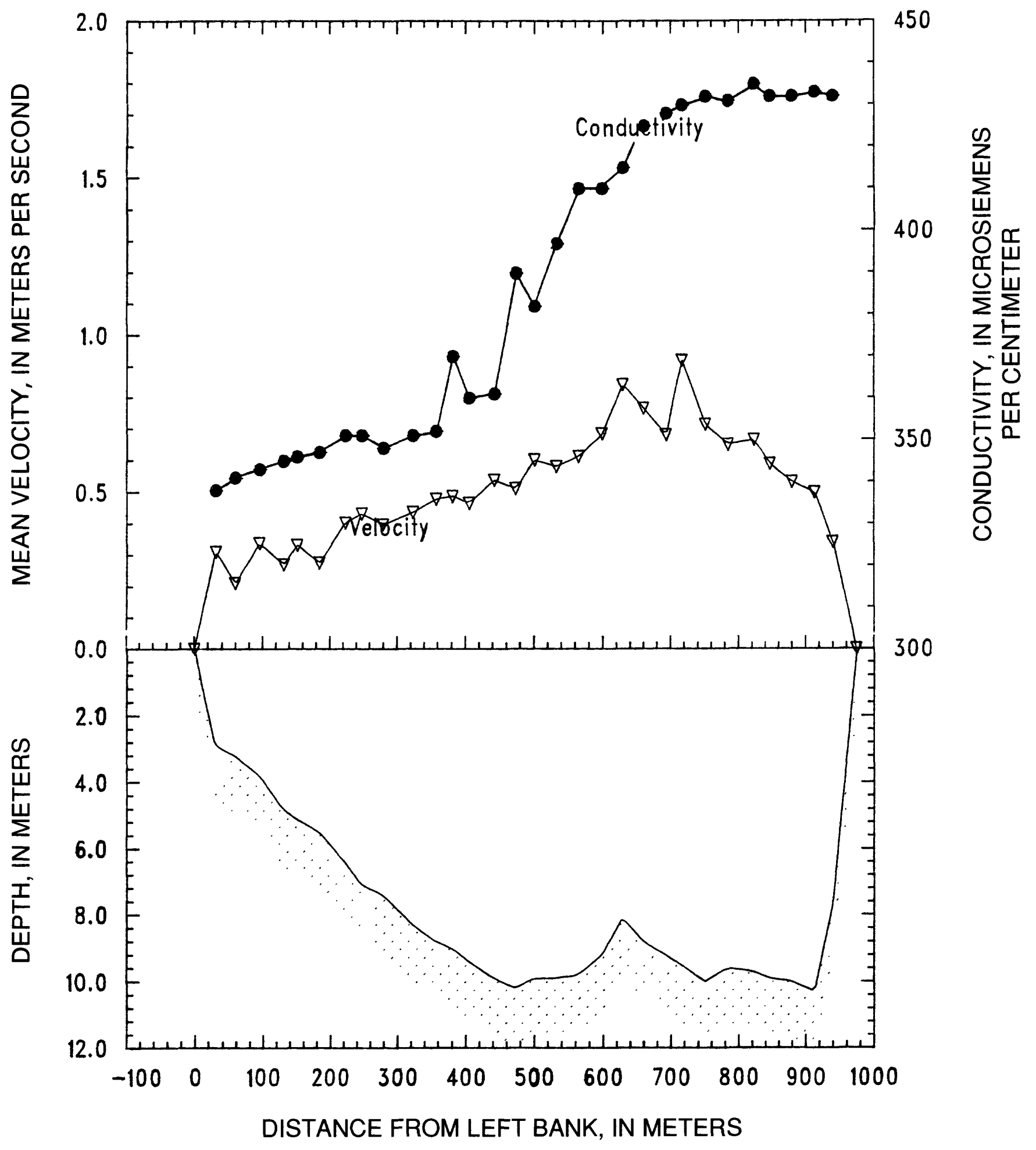

Figure 28. Ohio River at Olmsted, III. on December 6, 1987. 
STATION: Mississippi River below Hickman, Ky • $12-07-87$ PARTY: Black, Moody, and Stevens STARTING PORTABLE GAGE HEIGHT: $0.20 \mathrm{~m}$ ENDING GAGE HEIGHT: $0.13 \mathrm{~m}$ SUSP: Bag sampler and 300-1b weight

METER No: P8308282 DATE RATED: 4-14-88

REMARKS: Herb liked today because there was no rain. The transit rate was $14 \mathrm{~cm} / \mathrm{s}$ and the nozzle was $1 / 4$ inch. Only upcast velocities are listed. Total discharge was $8820 \mathrm{~m}^{3} / \mathrm{s}$.

\begin{tabular}{|c|c|c|c|c|c|c|c|c|}
\hline $\begin{array}{l}\text { Verti- } \\
\text { cal }\end{array}$ & $\begin{array}{l}\text { Distance } \\
\text { Erom } \\
\text { IEW } \\
(\mathrm{m})\end{array}$ & Depth & $\begin{array}{c}\text { Mean } \\
\text { velocity } \\
(\mathrm{m} / \mathrm{s})\end{array}$ & $\begin{array}{l}\text { Discharge } \\
\left(\mathrm{m}^{3} / \mathrm{s}\right)\end{array}$ & $\begin{array}{c}\text { Sample } \\
\text { volume } \\
\text { (mL) }\end{array}$ & $\begin{array}{l}\text { Temper- } \\
\text { ature } \\
\left({ }^{\circ} \mathrm{C}\right)\end{array}$ & $\mathrm{pH}$ & $\begin{array}{l}\text { Conductivity } \\
\text { (micro- } \\
\text { siemens } / \mathrm{cm} \text { ) }\end{array}$ \\
\hline LEW & 0 & 0.0 & 0.00 & 0 & -- & --- & -- & --- \\
\hline $01 \mathrm{~A}$ & 36 & 7.3 & 0.82 & 197 & 1860 & 8.5 & 8.3 & 426 \\
\hline $02 \mathrm{~B}$ & 66 & 7.4 & 0.92 & 220 & 2380 & 8.5 & 8.3 & 428 \\
\hline $03 A$ & 101 & 8.7 & 1.29 & 370 & 4120 & 8.4 & 8.2 & 431 \\
\hline $04 \mathrm{~B}$ & 132 & 8.7 & 1.26 & 351 & 4020 & 8.2 & 8.2 & 431 \\
\hline $05 A$ & 165 & 8.2 & 1.41 & 411 & 4070 & 7.8 & 3.2 & 432 \\
\hline $06 B$ & 203 & 7.8 & 1.28 & 234 & 4060 & 7.8 & 8.2 & 433 \\
\hline $\mathrm{x} 01$ & 212 & 7.8 & 1.30 & 152 & -- & --- & -- & --- \\
\hline $07 A$ & 233 & 7.6 & 1.17 & 178 & 3140 & 7.8 & 8.2 & 435 \\
\hline$x 02$ & 252 & 7.6 & 1.18 & 170 & -- & --- & -- & --- \\
\hline $08 B$ & 271 & 7.7 & 1.25 & 197 & 3140 & 8.2 & $8 . .2$ & 438 \\
\hline $09 A$ & 293 & 7.6 & 1.19 & 231 & 3310 & 8.3 & 8.3 & 438 \\
\hline $\mathrm{x} 03$ & 322 & 7.8 & 1.20 & 182 & -- & --- & -- & --- \\
\hline $10 B$ & 332 & 7.9 & 1.54 & 286 & 3680 & 8.6 & 8.3 & 442 \\
\hline $11 \mathrm{~A}$ & 369 & 7.5 & 1.30 & 298 & 2770 & 8.1 & 8.3 & 445 \\
\hline $12 \mathrm{~B}$ & 393 & 7.5 & 1.39 & 323 & 3290 & 7.6 & 8.3 & 441 \\
\hline $13 A$ & 431 & 7.6 & 1.26 & 317 & 3710 & 7.8 & 8.3 & 450 \\
\hline X05 & 459 & 7.5 & 1.13 & 199 & -- & --- & -- & --- \\
\hline $14 \mathrm{~B}$ & 478 & 8.5 & 1.15 & 187 & 3610 & 8.0 & 8.3 & 454 \\
\hline $15 \mathrm{~A}$ & 497 & 8.7 & 1.29 & 269 & 3660 & 8.3 & 8.3 & 456 \\
\hline $16 \mathrm{~B}$ & 526 & 8.6 & 1.07 & 337 & 3460 & 7.6 & 8.3 & 457 \\
\hline $17 \mathrm{~A}$ & 570 & 8.4 & 1.02 & 262 & 3500 & 7.9 & 8.3 & 462 \\
\hline $18 \mathrm{~B}$ & 587 & 8.9 & 1.07 & 228 & 3700 & 7.9 & 8.3 & 460 \\
\hline $\mathrm{x} 06$ & 618 & 9.2 & 1.10 & 218 & -- & --- & -- & --- \\
\hline $19 A$ & 630 & 8.9 & 1.12 & 249 & 3760 & 7.0 & 8.4 & 468 \\
\hline $20 B$ & 668 & 9.3 & 1.10 & 368 & 3560 & 7.2 & 8.2 & 471 \\
\hline $21 \mathrm{~A}$ & 702 & 9.7 & 1.00 & 326 & 3530 & 7.1 & 8.1 & 478 \\
\hline $22 \mathrm{~B}$ & 735 & 9.6 & 1.04 & 315 & 3460 & 7.6 & 8.4 & 485 \\
\hline $23 A$ & 765 & 10.3 & 0.95 & 319 & 3270 & 7.2 & 8.4 & 482 \\
\hline $24 B$ & 800 & 9.3 & 1.00 & 283 & 3480 & 6.8 & 8.4 & 474 \\
\hline $25 \mathrm{~A}$ & 826 & 9.5 & 0.92 & 298 & 2440 & 6.8 & 8.4 & 479 \\
\hline $26 \mathrm{~B}$ & 868 & 8.9 & 0.99 & 268 & 2930 & 6.9 & 8.4 & 480 \\
\hline $27 A$ & 887 & 8.6 & 0.93 & 212 & 2950 & 6.9 & 8.5 & 481 \\
\hline $28 B$ & 921 & 6.3 & 0.84 & 196 & 1660 & 6.8 & 8.4 & 481 \\
\hline $29 A$ & 961 & 5.7 & 0.75 & 128 & 1390 & 7.2 & 8.3 & 482 \\
\hline $30 B$ & 981 & 3.0 & 0.55 & 39 & 490 & 7.1 & 8.5 & 479 \\
\hline REW & 1008 & 0.0 & 0.00 & 0 & -- & --- & -- & --- \\
\hline
\end{tabular}




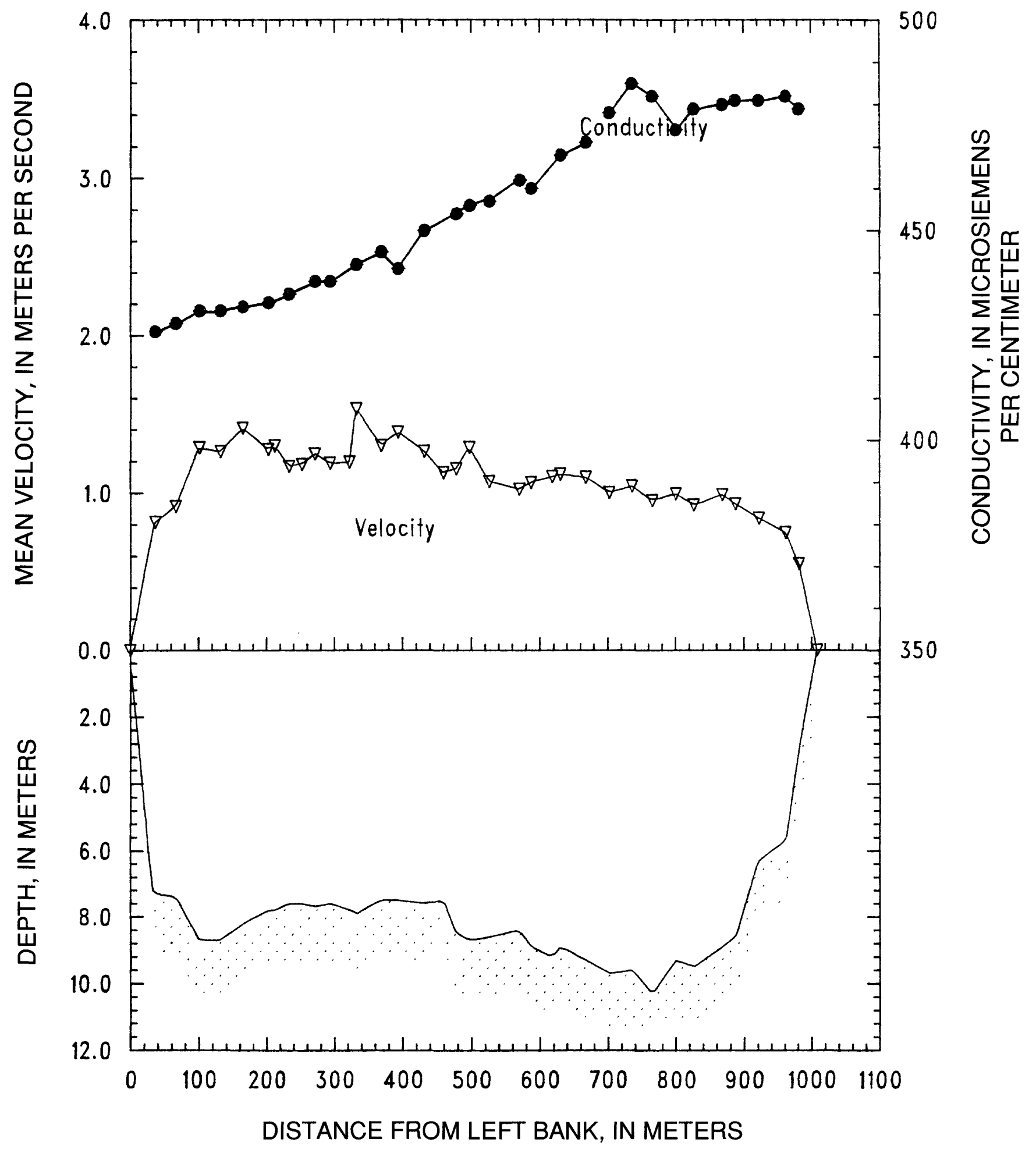

Figure 29. Mississippi River below Hickman, Ky. on December 7, 1987. 
STATION: Mississippi River at Fulton, Tenn.

PARTY: Black, Moody, and Stevens

STARTING GAGE HEIGHT: --

SUSP: Bag sampler and $300-1 \mathrm{~b}$ weight

METER NO: P8308282 DATE RATED: 4-14-88

REMARKS: Started at noon and finished in the dark on a very windy day.

Transit rate was $10 \mathrm{~cm} / \mathrm{s}$ and the nozzle, was $3 / 16$ inch. Only upcast velocities are listed. Total discharge was $9470 \mathrm{~m}^{3} / \mathrm{s}$.

\begin{tabular}{|c|c|c|c|c|c|c|c|c|}
\hline $\begin{array}{l}\text { Verti- } \\
\text { cal }\end{array}$ & $\begin{array}{c}\text { Distance } \\
\text { from } \\
\text { LEW } \\
(m)\end{array}$ & Depth & $\begin{array}{c}\text { Mean } \\
\text { velocity } \\
(\mathrm{m} / \mathrm{s})\end{array}$ & $\begin{array}{l}\text { Discharge } \\
\left(\mathrm{m}^{3} / \mathrm{s}\right)\end{array}$ & $\begin{array}{c}\text { Sample } \\
\text { volume } \\
\text { (mL) }\end{array}$ & $\begin{array}{l}\text { Temper- } \\
\text { ature } \\
\left({ }^{\circ} \mathrm{C}\right)\end{array}$ & $\mathrm{pH}$ & $\begin{array}{l}\text { Conductivity } \\
\text { (micro- } \\
\text { siemens/cm) }\end{array}$ \\
\hline LEW & 0 & 0.0 & 0.00 & 0 & -- & $-\cdots$ & - & $\ldots$ \\
\hline $30 \mathrm{~B}$ & 32 & 2.4 & 0.54 & 33 & 270 & 8.6 & 8.2 & 457 \\
\hline $29 A$ & 51 & 3.2 & 0.62 & 46 & 360 & 8.0 & 8.2 & 459 \\
\hline $28 B$ & 79 & 4.8 & 0.61 & 82 & 1040 & 8.2 & 8.0 & 460 \\
\hline $\mathrm{X} 09$ & 107 & 6.0 & 0.82 & 103 & -- & -- & -- & -- \\
\hline $27 \mathrm{~A}$ & 121 & 4.8 & 0.82 & 49 & 1640 & 8.0 & 7.9 & 460 \\
\hline X08 & 132 & 6.2 & 0.89 & 111 & -- & --- & -- & -- \\
\hline $25 A$ & 161 & 8.7 & 1.06 & 226 & 2660 & 8.7 & 8.2 & 460 \\
\hline $24 \mathrm{~B}$ & 181 & 9.9 & 1.15 & 353 & 2820 & 8.2 & 8.2 & 461 \\
\hline $23 A$ & 223 & 10.0 & 1.27 & 362 & 3800 & 9.6 & 8.2 & 460 \\
\hline $22 B$ & 238 & 10.6 & 1.22 & 299 & 4100 & 8.2 & 8.1 & 460 \\
\hline $21 \mathrm{~A}$ & 269 & 10.8 & 1.43 & 493 & 4000 & 8.9 & 8.2 & 461 \\
\hline $20 \mathrm{~B}$ & 302 & 11.2 & 1.37 & 422 & 5070 & 9.0 & 8.1 & 464 \\
\hline $19 A$ & 324 & 11.4 & 1.36 & 278 & 4610 & 9.4 & 8.2 & 461 \\
\hline $\mathrm{x} 07$ & 338 & 12.0 & 1.55 & 307 & -- & -- & -- & -- \\
\hline $18 B$ & 357 & 13.4 & 1.29 & 243 & 5210 & 8.2 & 8.1 & 463 \\
\hline$x 06$ & 366 & 14.8 & 1.29 & 315 & 4770 & 10.1 & 8.1 & 458 \\
\hline$x 05$ & 390 & 14.9 & 1.33 & 375 & -- & --- & -- & -- \\
\hline $16 \mathrm{~B}$ & 404 & 14.9 & 1.25 & 364 & 5400 & 8.6 & 8.2 & 459 \\
\hline $15 \mathrm{~A}$ & 429 & 14.5 & 1.10 & 383 & 4600 & 8.6 & 8.1 & 462 \\
\hline$\times 04$ & 452 & 14.4 & 1.51 & 425 & -- & -- & - & -- \\
\hline $14 \mathrm{~B}$ & 468 & 14.5 & 1.16 & 285 & 5560 & 9.7 & 8.1 & 460 \\
\hline $13 \mathrm{~A}$ & 486 & 14.4 & 1.27 & 465 & 5540 & 8.4 & 8.2 & 459 \\
\hline $12 B$ & 519 & 13.8 & 1.32 & 447 & 4910 & 8.3 & 8.1 & 463 \\
\hline $\mathrm{x} 03$ & 535 & 12.0 & 1.34 & 257 & -- & --- & - & $-\infty$ \\
\hline $11 \mathrm{~A}$ & 551 & 12.0 & 1.29 & 264 & 4270 & 9.9 & 8.2 & 465 \\
\hline $10 B$ & 569 & 12.0 & 1.30 & 351 & 4500 & 8.2 & 8.1 & 460 \\
\hline $\mathrm{x} 02$ & 596 & 11.9 & 1.15 & 260 & -- & -- & -- & -- \\
\hline 09A & 607 & 11.5 & 1.14 & 150 & 3760 & 8.5 & 8.1 & 462 \\
\hline $08 B$ & 619 & 11.2 & 1.10 & 233 & 2700 & 9.2 & 8.1 & 459 \\
\hline $\mathrm{x} 01$ & 645 & 11.2 & 1.22 & 301 & -- & --- & -- & $-\cdots$ \\
\hline $07 \mathrm{~A}$ & 663 & 12.2 & 1.06 & 277 & 3460 & 8.9 & 8.1 & 465 \\
\hline 68 & 688 & $\cdot 11.4$ & 0.98 & 312 & 3070 & 9.2 & 8.0 & 462 \\
\hline i) $5 \mathrm{~A}$ & 719 & 10.1 & 0.80 & 194 & 1860 & 8.2 & 8.0 & 460 \\
\hline $34 \mathrm{~B}$ & 736 & 9.4 & 0.72 & 163 & 1570 & 8.4 & 8.0 & 463 \\
\hline $33 \mathrm{~A}$ & 767 & 6.9 & 0.67 & 114 & 920 & 8.4 & 8.1 & 461 \\
\hline $92 B$ & 786 & 4.5 & 0.64 & 71 & 680 & 8.8 & 8.1 & 458 \\
\hline$J 1 A$ & 816 & 2.0 & 0.75 & 56 & 240 & 8.4 & 8.1 & 462 \\
\hline REW & 844 & 0.0 & 0.00 & 0 & -- & -- & -- & -- \\
\hline
\end{tabular}




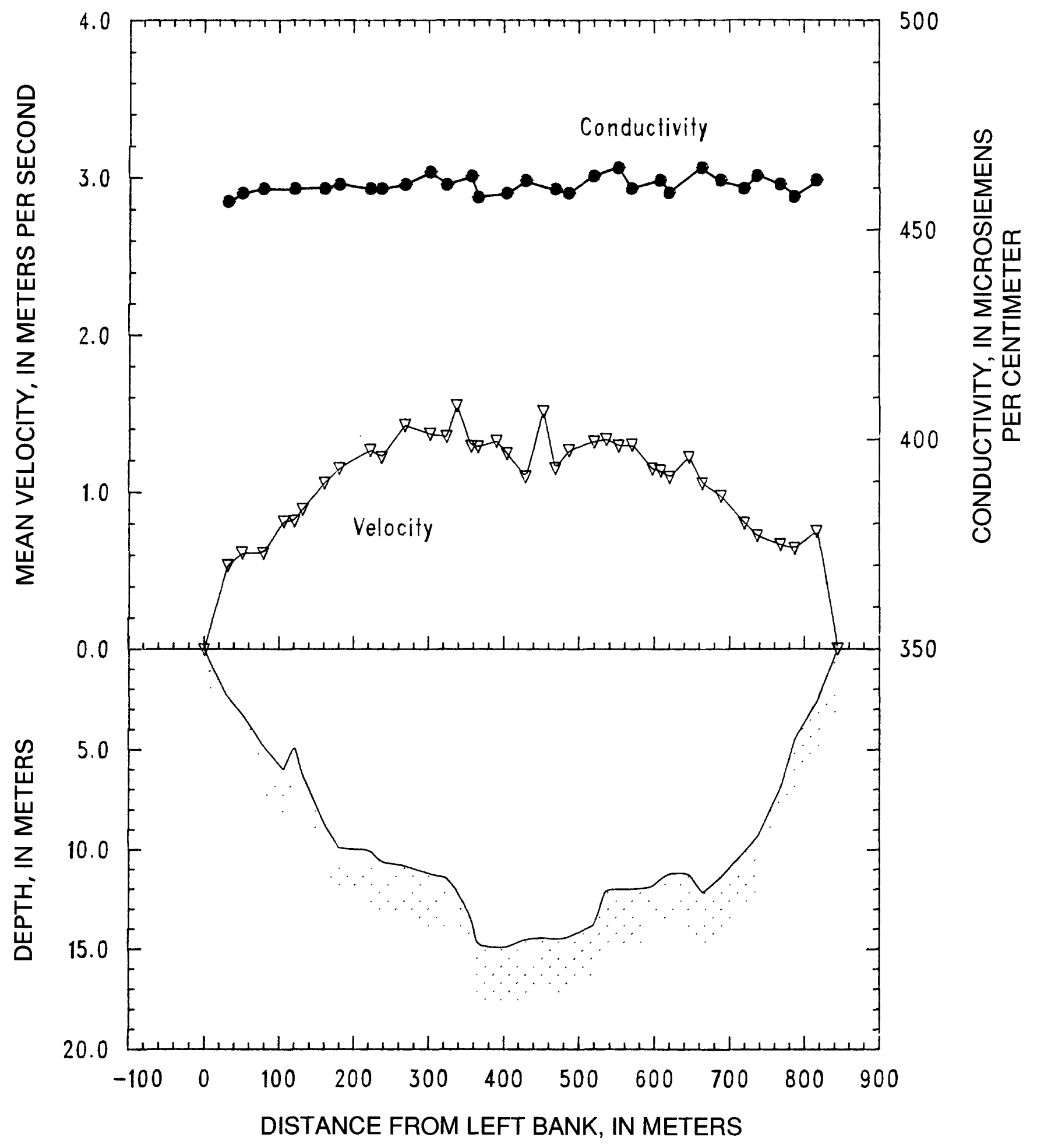

Figure 30. Mississippi River at Fulton, Tenn. on December 8, 1987. 
STATION: Mississippi River at Helena, Ark. 12-11-87

PARTY: Black, Moody, and Stevens

METER: $\quad$ SOLID CUP
HEIGHT: $9.65 \mathrm{ft}$.

STARTING GAGE HEIGHT: $9.70 \mathrm{ft}$.

SUSP: Bag sampler and 300-lb weight

METER NO: P8308282 DATE RATED: 4-14-88

REMARKS: Clear and sunny day. The transit rate was $22 \mathrm{~cm} / \mathrm{s}$ and the nozzle was $1 / 4$ inch. 3 Only upcast velocities are listed. The total discharge was $8770 \mathrm{~m}^{3} / \mathrm{s}$.

\begin{tabular}{|c|c|c|c|c|c|c|c|c|}
\hline $\begin{array}{l}\text { Verti- } \\
\text { cal }\end{array}$ & $\begin{array}{c}\text { Distance } \\
\text { from } \\
\text { LEW } \\
\text { (m) }\end{array}$ & Depth & $\begin{array}{c}\text { Mean } \\
\text { velocity } \\
\qquad(\mathrm{m} / \mathrm{s})\end{array}$ & $\begin{array}{c}\text { Discharge } \\
\left(\mathrm{m}^{3} / \mathrm{s}\right)\end{array}$ & $\begin{array}{c}\text { Sample } \\
\text { volume } \\
(\mathrm{mL})\end{array}$ & $\begin{array}{l}\text { Temper- } \\
\text { ature } \\
\left({ }^{\circ} \mathrm{C}\right)\end{array}$ & $\mathrm{pH}$ & $\begin{array}{l}\text { Conductivity } \\
\text { (micro- } \\
\text { siemens/cm) }\end{array}$ \\
\hline LEW & 0 & 0.0 & 0.00 & 0 & -- & --- & -- & --- \\
\hline $30 \mathrm{~B}$ & 20 & 7.2 & 1.47 & 196 & 2120 & 8.7 & 8.0 & 457 \\
\hline$X 12$ & 37 & 10.6 & 1.67 & 247 & -- & --- & -- & --- \\
\hline $29 A$ & 48 & 10.7 & 1.81 & 301 & 5000 & 8.9 & 8.1 & 458 \\
\hline$X 11$ & 68 & 10.8 & 1.84 & 327 & -- & --- & -- & --- \\
\hline $28 B$ & 81 & 10.9 & 1.93 & 200 & 5500 & 8.7 & 8.0 & 455 \\
\hline$x 10$ & 87 & 11.2 & 1.70 & 190 & -- & --- & -- & -- \\
\hline $27 \mathrm{~A}$ & 101 & 10.9 & 1.62 & 213 & 4480 & 8.7 & 8.0 & 453 \\
\hline$x 09$ & 111 & 10.7 & 1.64 & 245 & - & -- & -- & - \\
\hline $26 B$ & 129 & 10.7 & 1.54 & 189 & 4890 & 8.7 & 8.1 & 454 \\
\hline$x 08$ & 134 & 10.7 & 1.65 & 132 & -- & --- & -- & --- \\
\hline $25 \mathrm{~A}$ & 144 & 10.3 & 1.53 & 198 & 4260 & 8.6 & 8.0 & 454 \\
\hline$x 07$ & 159 & 10.6 & 1.79 & 284 & -- & $\ldots$ & - & -- \\
\hline $24 B$ & 174 & 10.5 & 1.64 & 180 & 4720 & 9.1 & 8.1 & 451 \\
\hline$x 06$ & 180 & 10.8 & 1.70 & 192 & -- & -- & -- & -- \\
\hline $23 A$ & 195 & 10.5 & 1.59 & 200 & 4780 & 8.8 & 8.0 & 453 \\
\hline$x 05$ & 204 & 10.2 & 1.81 & 202 & -- & --- & -- & --- \\
\hline $22 B$ & 217 & 10.2 & 1.64 & 209 & 4480 & 9.2 & 7.8 & 451 \\
\hline X04 & 229 & 10.2 & 1.64 & 184 & - & -- & -- & -- \\
\hline $21 \mathrm{~A}$ & 239 & 10.0 & 1.36 & 163 & 3760 & 8.7 & 7.9 & 451 \\
\hline xo3 & 253 & 9.5 & 1.60 & 198 & -- & --- & -- & --- \\
\hline $20 \mathrm{~B}$ & 265 & 9.5 & 1.70 & 226 & 4060 & 8.6 & 8.0 & 450 \\
\hline $\mathrm{x} 02$ & 281 & 9.0 & 1.48 & 181 & -- & -- & -- & -- \\
\hline $19 \mathrm{~A}$ & 292 & 8.8 & 1.45 & 140 & 3600 & 8.5 & 7.9 & 449 \\
\hline $\mathrm{x} 01$ & 303 & 9.0 & 1.50 & 156 & -- & -- & -- & -- \\
\hline $18 \mathrm{~A}$ & 315 & 8.7 & 1.58 & 200 & 3480 & -- & -- & --- \\
\hline $17 \mathrm{~A}$ & 332 & 8.2 & 1.64 & 329 & 3550 & 8.7 & 7.9 & 448 \\
\hline $26 \mathrm{~B}$ & 364 & 7.6 & 1.11 & 223 & 2510 & -- & - & -- \\
\hline $15 \mathrm{~A}$ & 385 & 7.4 & 1.55 & 269 & 2590 & 8.7 & 7.9 & 444 \\
\hline $14 \mathrm{~B}$ & 411 & 7.3 & $i .29$ & 218 & 2270 & --- & -- & -- \\
\hline $23 \mathrm{~A}$ & 4.31 & 7.5 & 1.28 & 250 & 2310 & 8.6 & 7.9 & 441 \\
\hline $2 \mathrm{~B}$ & 463 & 8.5 & 1.35 & 310 & 2930 & -- & - & -- \\
\hline $11 \mathrm{~A}$ & 485 & 8.7 & $i .41$ & 240 & 2340 & 8.7 & 7.9 & 439 \\
\hline $10 B$ & 502 & 8.4 & i. 38 & 203 & 2660 & --- & -- & -- \\
\hline $09 A$ & 520 & 8.2 & 1.05 & 202 & 1920 & 8.5 & 7.9 & 445 \\
\hline $08 \mathrm{~B}$ & 549 & 8.0 & 1.29 & 320 & 2120 & --- & -- & -- \\
\hline $7 \mathrm{~A}$ & 582 & 7.4 & 1.12 & 185 & 2120 & 8.5 & 7.9 & 438 \\
\hline $06 \mathrm{~B}$ & 534 & 7.6 & 1.12 & 191 & 1840 & -- & -- & -- \\
\hline
\end{tabular}


STATION: Mississippi River at Helena, Ark.

$12-11-87$

(continued)

\begin{tabular}{|c|c|c|c|c|c|c|c|c|}
\hline $\begin{array}{c}\text { Verti- } \\
\text { cal }\end{array}$ & $\begin{array}{c}\text { Distance } \\
\text { from } \\
\text { LEW } \\
(\mathrm{m})\end{array}$ & Depth & $\begin{array}{c}\text { Mean } \\
\text { velocity } \\
(\mathrm{m} / \mathrm{s})\end{array}$ & $\begin{array}{c}\text { Discharge } \\
\left(\mathrm{m}^{3} / \mathrm{s}\right)\end{array}$ & $\begin{array}{c}\text { Sample } \\
\text { volume } \\
(\mathrm{mL})\end{array}$ & $\begin{array}{c}\text { Temper- } \\
\text { ature } \\
\left({ }^{\circ} \mathrm{C}\right)\end{array}$ & $\mathrm{pH}$ & $\begin{array}{l}\text { Conductivity } \\
\text { (micro- } \\
\text { siemens } / \mathrm{cm} \text { ) }\end{array}$ \\
\hline $05 \mathrm{~A}$ & 627 & 6.4 & 1.43 & 280 & 1480 & 8.6 & 7.9 & 438 \\
\hline $04 B$ & 655 & 6.2 & 1.20 & 167 & 1360 & --- & -- & -- \\
\hline $03 A$ & 672 & 4.8 & 1.08 & 114 & 1170 & 8.6 & 7.8 & 436 \\
\hline $02 \mathrm{~B}$ & 699 & 3.3 & 1.27 & 106 & 660 & -- & -- & -- \\
\hline $01 \mathrm{~A}$ & 722 & 1.5 & 0.29 & 11 & 510 & 10.1 & 8.0 & 430 \\
\hline REW & 750 & 0.0 & 0.00 & 0 & -- & --- & - & -- \\
\hline
\end{tabular}




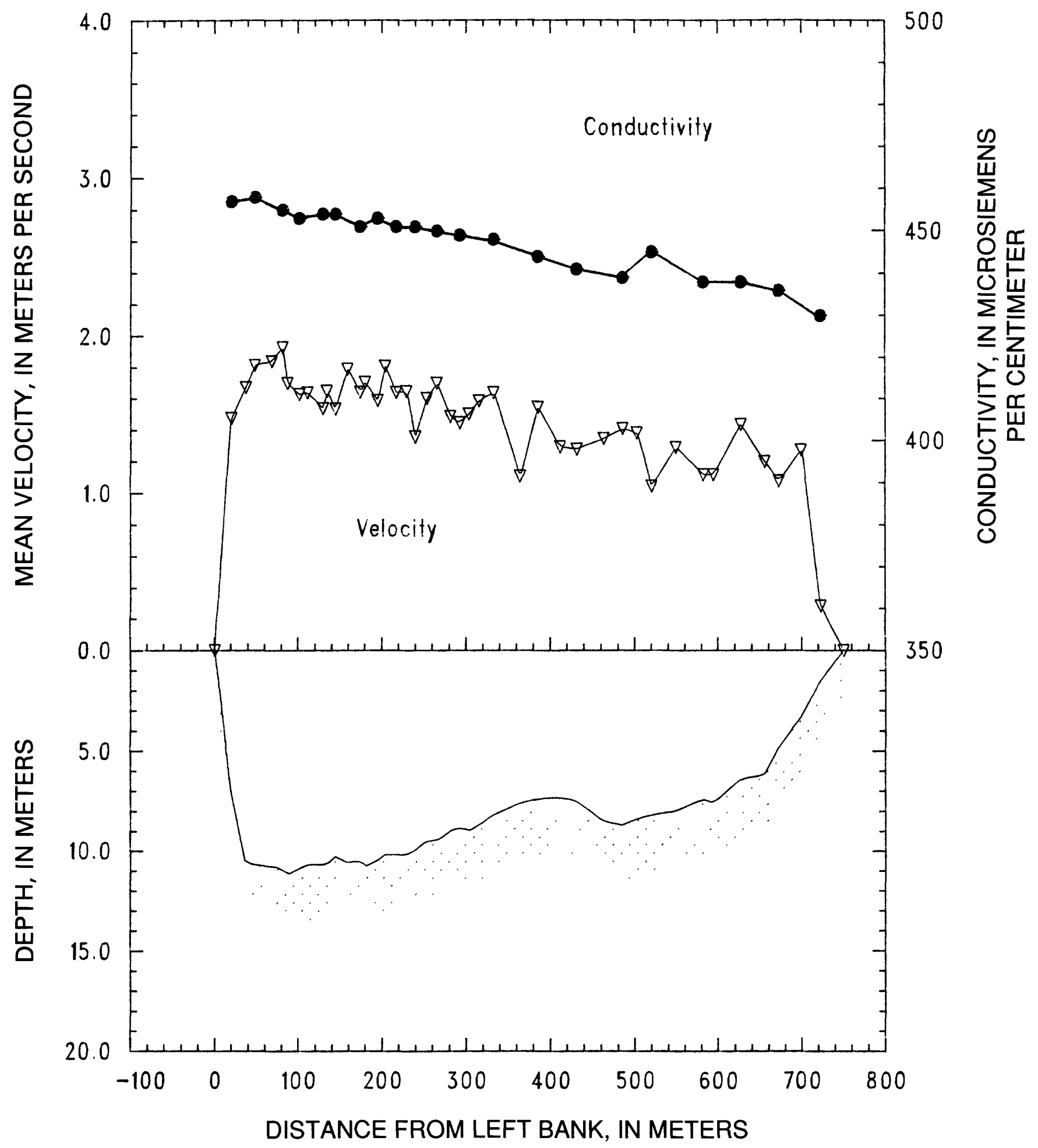

Figure 31. Mississippi River at Helena, Ark. on December 11, 1987. 
STATION: White River at Mile 11.5, Ark. $12-12-87$

PARTY: Black, Moody, and Stevens

SOLID CUP

STARTING ARBITRARY GAGE HEIGHT: $0.20 \mathrm{~m}$ ENDING GAGE HEIGHT: $0.15 \mathrm{~m}$

SUSP: Bag sampler and $150-1 \mathrm{~b}$ weight

METER NO: P8308282 DATE RATED: 4-7-88

REMARKS: Transit rate was $10 \mathrm{~cm} / \mathrm{s}$ and the nozzle was $5 / 16$ inch. Only upcast velocities are listed. The total discharge was $519 \mathrm{~m} / \mathrm{s}$.

\begin{tabular}{|c|c|c|c|c|c|c|c|c|}
\hline $\begin{array}{l}\text { erti- } \\
\text { cal }\end{array}$ & $\begin{array}{c}\text { Distance } \\
\text { from } \\
\text { LEW } \\
(\mathrm{m})\end{array}$ & Depth & $\begin{array}{c}\text { Mean } \\
\text { velocity } \\
(\mathrm{m} / \mathrm{s})\end{array}$ & $\begin{array}{c}\text { Di scharge } \\
\left(\mathrm{m}^{3} / \mathrm{s}\right)\end{array}$ & $\begin{array}{c}\text { Sample } \\
\text { volume } \\
(\mathrm{mL})\end{array}$ & $\begin{array}{c}\text { Temper- } \\
\text { ature } \\
\left({ }^{\circ} \mathrm{C}\right)\end{array}$ & $\mathrm{pH}$ & $\begin{array}{l}\text { Conductivity } \\
\text { (micro- } \\
\text { siemens } / \mathrm{cm} \text { ) }\end{array}$ \\
\hline LEW & 0 & 0.0 & 0.00 & 0 & -- & -- & -- & -- \\
\hline $10 \mathrm{~A}$ & 17 & 5.0 & 0.61 & 55 & 4960 & 11.9 & 7.7 & 239 \\
\hline $10 B$ & 17 & 5.0 & 0.61 & -- & 5440 & -- & -- & --- \\
\hline $09 A$ & 32 & 4.8 & 0.79 & 29 & 6010 & 11.4 & 7.8 & 230 \\
\hline $09 B$ & 32 & 4.8 & 0.79 & -- & 6600 & $\rightarrow-$ & -- & -- \\
\hline $\mathrm{X} 01$ & 36 & 4.8 & 0.80 & 29 & -- & $\rightarrow$ & - & -- \\
\hline $08 \mathrm{~A}$ & 51 & 4.6 & 0.84 & 58 & 6610 & 10.9 & 7.8 & 215 \\
\hline $08 \mathrm{~B}$ & 51 & 4.6 & 0.84 & - & 6360 & -- & -- & $-\infty$ \\
\hline $07 \mathrm{~A}$ & 62 & 4.6 & 0.81 & 50 & 6240 & 11.1 & 7.8 & 222 \\
\hline $07 \mathrm{~B}$ & 62 & 4.6 & 0.81 & -- & 6250 & -- & -- & $-\infty$ \\
\hline $06 \mathrm{~A}$ & 78 & 4.5 & 0.81 & 65 & 5750 & 10.4 & 7.5 & 213 \\
\hline $06 \mathrm{~B}$ & 78 & 4.5 & 0.81 & -- & 6400 & --- & -- & --- \\
\hline $05 \mathrm{~A}$ & 98 & 4.2 & 0.76 & 49 & 5340 & 10.6 & 7.8 & 214 \\
\hline $05 B$ & 98 & 4.2 & 0.76 & -- & 5020 & -- & -- & --- \\
\hline $04 \mathrm{~A}$ & 109 & 4.2 & 0.74 & 45 & 5290 & 10.9 & 7.8 & 219 \\
\hline $04 \mathrm{~B}$ & 109 & 4.2 & 0.74 & -- & 5200 & -- & -- & --- \\
\hline $03 \mathrm{~A}$ & 127 & 4.3 & 0.68 & 57 & 4700 & 11.1 & 7.8 & 214 \\
\hline $03 B$ & 127 & 4.3 & 0.68 & -- & 4450 & --- & - & --- \\
\hline $02 \mathrm{~A}$ & 148 & 4.1 & 0.69 & 47 & 4770 & 10.6 & 7.8 & 214 \\
\hline $02 \mathrm{~B}$ & 148 & 4.1 & 0.69 & -- & 4310 & --- & -- & --- \\
\hline $01 \mathrm{~A}$ & 160 & 4.1 & 0.60 & 35 & 5060 & 10.7 & 7.7 & 211 \\
\hline O1B & 160 & 4.1 & 0.60 & -- & 5790 & -- & -- & -- \\
\hline REW & 177 & 0.0 & 0.00 & 0 & - & --- & -- & -- \\
\hline
\end{tabular}




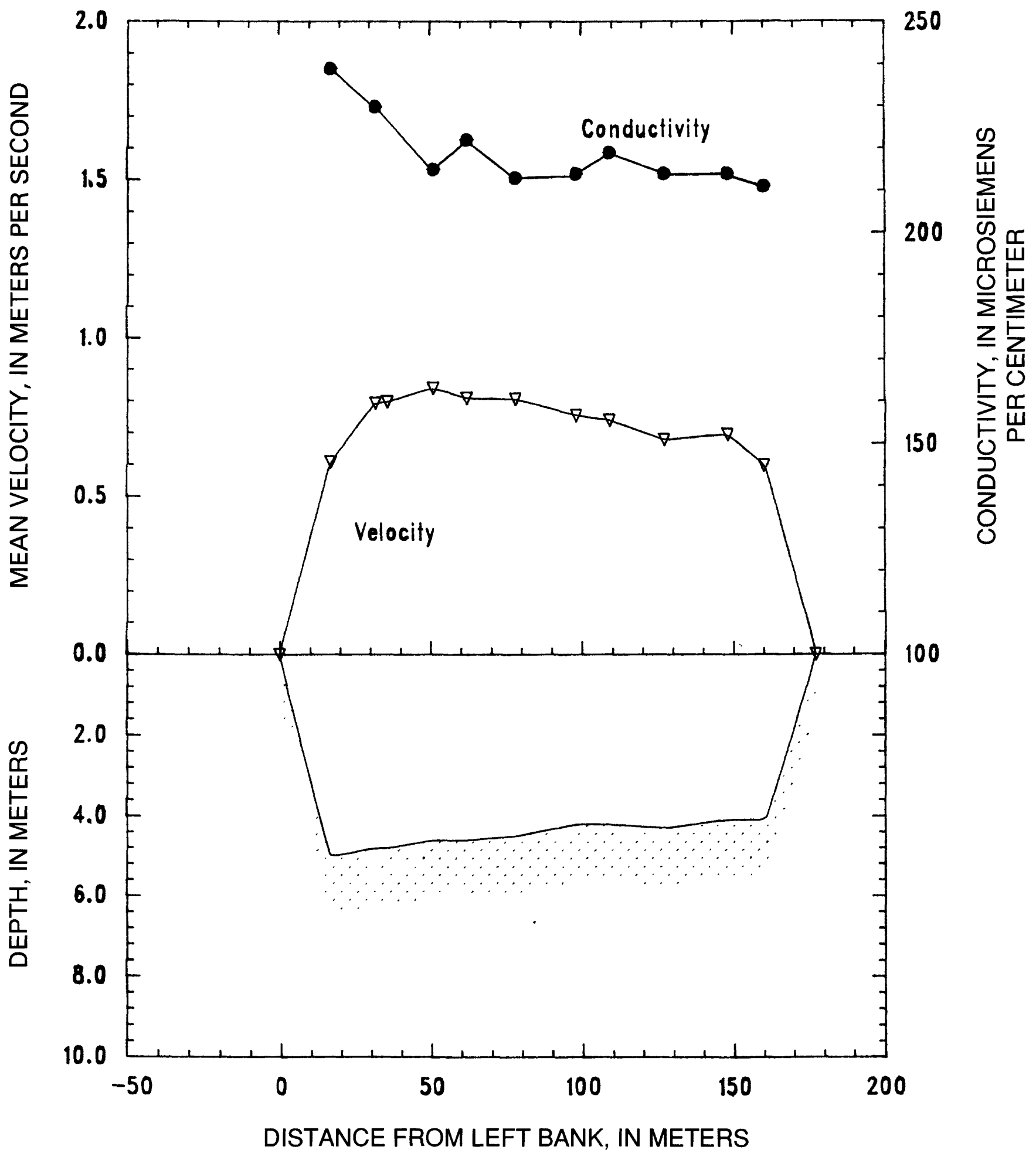

Figure 32. White River at Mile 11.5, Ark. on December 12, 1987. 
STATION: Mississippi River above Arkansas City, Ark. PARTY: Black, Moody, and Stevens STARTING GAGE HEIGHT: FNDING GAGE HEIC

SUSP: Bag sampler and 300-1b weight

METER NO: P8308282 DATE RATED: 4-12-88

REMARKS: It was very windy and raining. The transit rate was $12 \mathrm{~cm} / \mathrm{s}$ and the nozzle was $3 / 16$ inch. 3 Only upcast velocities are listed. The total discharge was $9920 \mathrm{~m}^{3} / \mathrm{s}$.

\begin{tabular}{|c|c|c|c|c|c|c|c|c|}
\hline $\begin{array}{c}\text { Verti- } \\
\text { cal }\end{array}$ & $\begin{array}{c}\text { Distance } \\
\text { from } \\
\text { LEW } \\
(\mathrm{m})\end{array}$ & Depth & $\begin{array}{l}\text { Mean } \\
\text { velocity } \\
(m / s)\end{array}$ & $\begin{array}{l}\text { Discharge } \\
\left(\mathrm{m}^{3} / \mathrm{s}\right)\end{array}$ & $\begin{array}{l}\text { Sample } \\
\text { volume } \\
\text { (mL) }\end{array}$ & $\begin{array}{l}\text { Temper- } \\
\text { ature } \\
\left({ }^{\circ} \mathrm{C}\right)\end{array}$ & $\mathrm{pH}$ & $\begin{array}{l}\text { Conductivity } \\
\text { (micro- } \\
\text { siemens/cm) }\end{array}$ \\
\hline LEW & 0 & 0.0 & 0.00 & 0 & -- & -- & -- & -- \\
\hline $30 \mathrm{~B}$ & 32 & 3.4 & 0.26 & 26 & 370 & 8.2 & 8.0 & 455 \\
\hline $29 A$ & 57 & 5.4 & 0.35 & 53 & 830 & 8.2 & 8.0 & 446 \\
\hline $28 B$ & 88 & 8.5 & 0.66 & 169 & 1210 & 8.3 & 8.0 & 454 \\
\hline $27 \mathrm{~A}$ & 117 & 9.8 & 0.78 & 226 & 1540 & 8.2 & 8.0 & 442 \\
\hline $26 B$ & 147 & 12.1 & 0.87 & 256 & 2280 & 8.3 & 8.0 & 455 \\
\hline $25 A$ & 166 & 11.5 & 0.87 & 131 & 3080 & 8.2 & 8.0 & 445 \\
\hline $\mathrm{X} 15$ & 173 & 11.5 & 1.04 & 137 & -- & -- & -- & -- \\
\hline$X 14$ & 189 & 11.3 & 1.07 & 211 & -- & -- & -- & -- \\
\hline $24 B$ & 208 & 11.7 & 1.23 & 280 & 3340 & 8.3 & 8.1 & 445 \\
\hline $23 A$ & 228 & 10.4 & 1.35 & 315 & 3480 & 8.3 & 8.1 & 443 \\
\hline $22 \mathrm{~B}$ & 253 & 10.8 & 1.29 & 445 & 4310 & 8.3 & 7.9 & 450 \\
\hline $21 \mathrm{~A}$ & 292 & 11.2 & 1.23 & 304 & 3210 & 8.4 & 8.0 & 445 \\
\hline$x 13$ & 297 & 11.8 & 1.11 & 170 & -- & -- & -- & -- \\
\hline $20 B$ & 318 & 11.7 & 1.22 & 257 & 5630 & 8.3 & 7.9 & 448 \\
\hline$X 12$ & 333 & 11.7 & 1.23 & 238 & -- & --- & -- & -- \\
\hline $19 A$ & 351 & 11.6 & 1.45 & 294 & 4530 & 8.5 & 8.0 & 445 \\
\hline $\mathrm{X} 11$ & 368 & 12.2 & 1.32 & 257 & -- & -- & -- & -- \\
\hline $18 \mathrm{~B}$ & 383 & 13.9 & 1.19 & 264 & 4820 & 8.5 & 8.0 & 448 \\
\hline $\mathrm{X} 10$ & 400 & 14.1 & 1.08 & 229 & -- & -- & -- & -- \\
\hline $17 \mathrm{~A}$ & 413 & 14.9 & 1.03 & 246 & 5260 & 8.6 & 7.9 & 450 \\
\hline $\mathrm{X} 09$ & 432 & 15.6 & 1.16 & 299 & -- & -- & -- & - \\
\hline $16 \mathrm{~B}$ & 446 & 16.0 & 1.08 & 284 & 5260 & 8.7 & 8.0 & 455 \\
\hline $\mathrm{X} 08$ & 465 & 15.5 & 1.12 & 244 & - & -- & -- & -- \\
\hline $15 \mathrm{~A}$ & 474 & 15.3 & 1.09 & 226 & 4900 & 8.7 & 8.0 & 451 \\
\hline $\mathrm{X} 07$ & 492 & 15.0 & 1.10 & 248 & -- & --- & -- & --- \\
\hline $14 \mathrm{~B}$ & 504 & 14.7 & 1.19 & 184 & 4040 & 8.7 & 8.0 & 454 \\
\hline $\mathrm{X} 06$ & 513 & 14.7 & 1.11 & 195 & - & -- & -- & -- \\
\hline$x 05$ & 528 & 14.5 & 1.18 & 231 & -- & -- & -- & --- \\
\hline $\mathrm{x} 04$ & 540 & 14.3 & 1.16 & 141 & -- & -- & -- & --- \\
\hline$: 3 A$ & 545 & 14.5 & 1.08 & 110 & 4130 & 8.7 & 8.0 & 457 \\
\hline $12 \mathrm{~B}$ & 554 & 14.1 & 1.17 & 222 & 4560 & 8.7 & 8.0 & 454 \\
\hline$x 03$ & 572 & 13.3 & 1.04 & 207 & -- & -- & -- & -- \\
\hline $11 \mathrm{~A}$ & 584 & 12.9 & 1.12 & 217 & 2980 & 8.8 & 8.0 & 454 \\
\hline $\mathrm{X} 02$ & 602 & 12.6 & 1.17 & 228 & - & -- & -- & -- \\
\hline $10 B$ & 615 & 12.6 & 1.00 & 221 & 3760 & 8.7 & 8.0 & 455 \\
\hline $\mathrm{x} 01$ & 637 & 12.5 & 1.06 & 252 & - & -- & -- & -- \\
\hline $09 A$ & 653 & 11.9 & 0.99 & 218 & 2880 & 8.8 & 8.0 & 454 \\
\hline $08 \mathrm{~B}$ & 674 & 11.8 & 0.87 & 263 & 2240 & 8.8 & 8.0 & 457 \\
\hline
\end{tabular}


STATION: Mississippi River above Arkansas City, Ark.

$12-13-87$ (continued)

\begin{tabular}{|c|c|c|c|c|c|c|c|c|}
\hline $\begin{array}{c}\text { Verti- } \\
\text { cal }\end{array}$ & $\begin{array}{c}\text { Distance } \\
\text { from } \\
\text { LEW } \\
(\mathrm{m})\end{array}$ & $\begin{array}{l}\text { Depth } \\
\text { (m) }\end{array}$ & $\begin{array}{l}\text { Mean } \\
\text { velocity } \\
(\mathrm{m} / \mathrm{s})\end{array}$ & $\begin{array}{l}\text { Discharge } \\
\left(\mathrm{m}^{3} / \mathrm{s}\right)\end{array}$ & $\begin{array}{c}\text { Sample } \\
\text { volume } \\
(\mathrm{mL})\end{array}$ & $\begin{array}{c}\text { Temper- } \\
\text { ature } \\
\left({ }^{\circ} \mathrm{C}\right)\end{array}$ & $\mathrm{pH}$ & $\begin{array}{l}\text { Conductivity } \\
\text { (micro- } \\
\text { siemens } / \mathrm{cm} \text { ) }\end{array}$ \\
\hline $07 \mathrm{~A}$ & 704 & 11.7 & 0.86 & 236 & 2830 & 8.9 & 8.0 & 455 \\
\hline $06 \mathrm{~B}$ & 721 & 11.5 & 0.93 & 298 & 1800 & 8.9 & 7.9 & 456 \\
\hline $05 \mathrm{~A}$ & 760 & 11.0 & 0.69 & 246 & 1500 & 8.8 & 8.0 & 457 \\
\hline $04 \mathrm{~B}$ & 786 & 11.1 & 0.78 & 263 & 1980 & 8.8 & 8.0 & 457 \\
\hline $03 \mathrm{~A}$ & 821 & 10.6 & 0.60 & 208 & 1040 & 8.8 & 7.8 & 456 \\
\hline $02 B$ & 851 & 8.9 & 0.48 & 127 & 840 & 8.8 & 8.0 & 456 \\
\hline $01 \mathrm{~A}$ & 881 & 4.5 & 0.33 & 39 & 390 & 9.0 & 8.0 & 456 \\
\hline REW & 904 & 0.0 & 0.00 & 0 & -- & -- & -- & -- \\
\hline
\end{tabular}




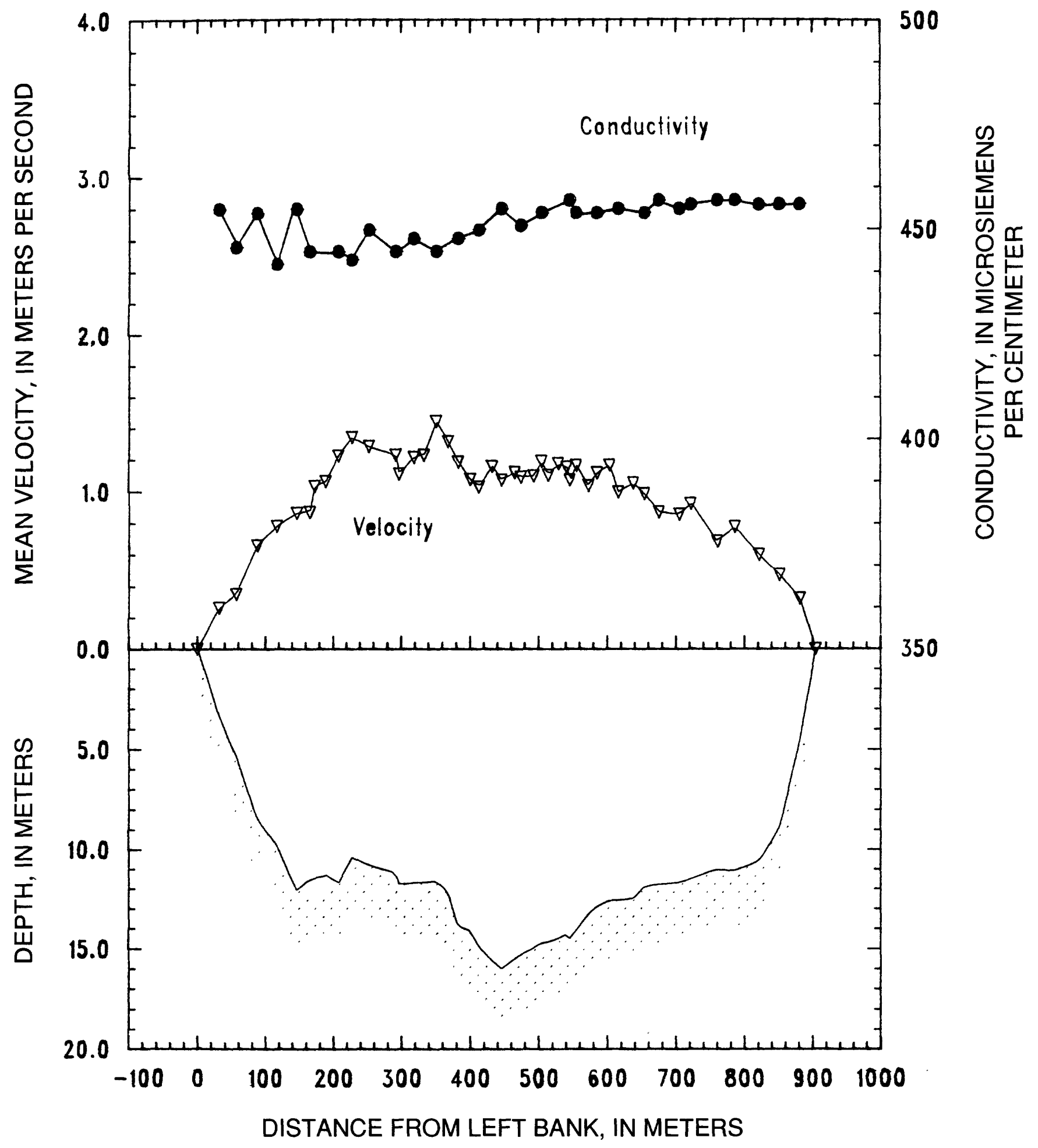

Figure 33. Mississippi River above Arkansas City, Ark. on December 13, 1987. 
STATION: Yazoo River at Mile 10, Miss. PARTY: Black, Moody, and Stevens STARTING ARBITRARY GAGE HEIGHT: $0.20 \mathrm{~m}$ ENDING GAGE HEIGHT: $0.15 \mathrm{~m}$ SUSP: Bag sampler and 150-1b weight METER NO: P8308282 DATE RATED: 14-7-88

REMARKS: Transit rate was $6 \mathrm{~cm} / \mathrm{s}$ and there was no nozzle on the bag sampler. Only upcast velocities are listed. The total discharge was $177 \mathrm{~m} / \mathrm{s}$.

\begin{tabular}{|c|c|c|c|c|c|c|c|c|}
\hline $\begin{array}{c}\text { Verti- } \\
\text { cal }\end{array}$ & $\begin{array}{l}\text { Distance } \\
\text { from } \\
\text { LEW } \\
\text { (m) }\end{array}$ & Depth & $\begin{array}{c}\text { Mean } \\
\text { velocity } \\
(\mathrm{m} / \mathrm{s})\end{array}$ & $\begin{array}{l}\text { Discharge } \\
\left(\mathrm{m}^{3} / \mathrm{s}\right)\end{array}$ & $\begin{array}{c}\text { Sample } \\
\text { volume } \\
(\mathrm{mL})\end{array}$ & $\begin{array}{c}\text { Temper- } \\
\text { ature } \\
\left({ }^{\circ} \mathrm{C}\right)\end{array}$ & $\mathrm{pH}$ & $\begin{array}{l}\text { Conductivity } \\
\text { (micro- } \\
\text { siemens } / \mathrm{cm} \text { ) }\end{array}$ \\
\hline LEW & 0 & 0.0 & 0.00 & 0 & -- & --- & -- & --- \\
\hline $01 \mathrm{~A}$ & 9 & 3.0 & 0.30 & 9 & 1050 & 12.3 & 6.8 & 83 \\
\hline $01 B$ & 9 & 3.0 & 0.30 & -- & 1860 & -- & -- & -- \\
\hline $02 A$ & 19 & 4.5 & 0.35 & 15 & 2240 & 12.3 & 6.8 & 85 \\
\hline $02 \mathrm{~B}$ & 19 & 4.5 & 0.35 & -- & 3950 & -- & -- & -- \\
\hline $03 \mathrm{~A}$ & 28 & 5.2 & 0.39 & 20 & 6150 & 12.3 & 6.8 & 88 \\
\hline $03 B$ & 28 & 5.2 & 0.39 & -- & 6160 & -- & -- & -- \\
\hline $04 \mathrm{~A}$ & 39 & 5.5 & 0.39 & 22 & 6350 & 12.7 & 6.8 & 86 \\
\hline $04 \mathrm{~B}$ & 39 & 5.5 & 0.39 & -- & 6480 & -- & -- & -- \\
\hline $05 \mathrm{~A}$ & 49 & 5.5 & 0.39 & 21 & 6390 & 12.5 & 6.9 & 83 \\
\hline $05 B$ & 49 & 5.5 & 0.39 & -- & 6070 & -- & -- & -- \\
\hline $06 \mathrm{~A}$ & 59 & 5.5 & 0.39 & 25 & 5480 & 12.4 & 6.9 & 81 \\
\hline $06 \mathrm{~B}$ & 59 & 5.5 & 0.39 & -- & 5900 & -- & -- & -- \\
\hline $07 A$ & 73 & 5.7 & 0.38 & 25 & 6230 & 12.4 & 6.7 & 86 \\
\hline 07B & 73 & 5.7 & 0.38 & -- & 6280 & -- & -- & -- \\
\hline $08 \mathrm{~A}$ & 82 & 5.9 & 0.35 & 21 & 5250 & 12.5 & 6.9 & 82 \\
\hline $08 B$ & 82 & 5.9 & 0.35 & -- & 6180 & -- & -- & -- \\
\hline $09 A$ & 93 & 6.1 & 0.20 & 14 & 2230 & 12.3 & 6.9 & 83 \\
\hline $09 B$ & 93 & 6.1 & 0.20 & -- & 1530 & -- & -- & -- \\
\hline $10 A$ & 105 & 3.2 & 0.12 & 5 & 820 & 12.3 & 7.0 & 87 \\
\hline $10 B$ & 105 & 3.2 & 0.12 & - & 510 & -- & -- & -- \\
\hline REW & 120 & 0.0 & 0.00 & 0 & -- & --- & -- & -- \\
\hline
\end{tabular}




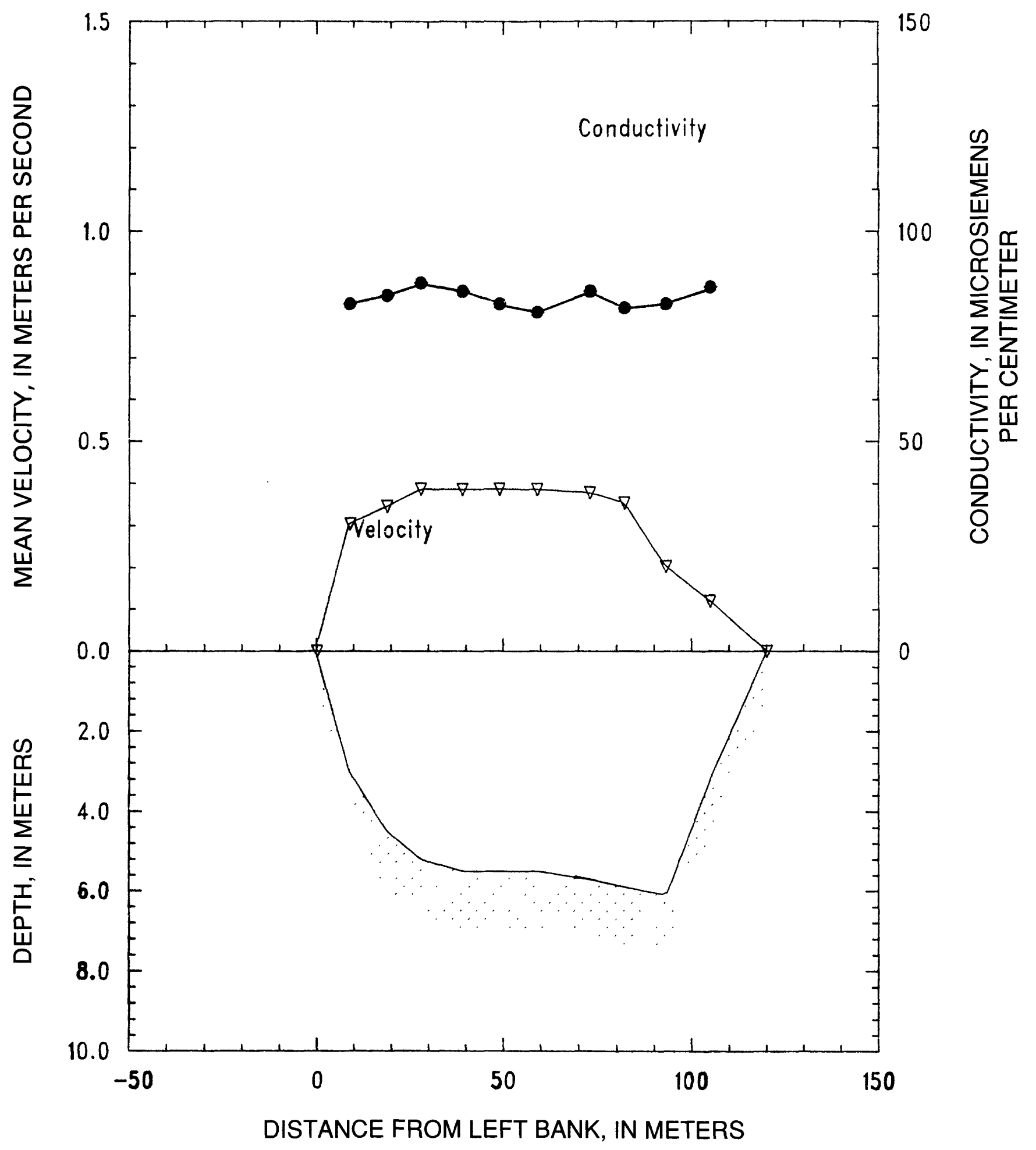

Figure 34. Yazoo River at Mile 10, Miss. on December 14, 1987. 
STATION: Mississippi River below Vicksburg, Miss.

PARTY: Black, Moody, and Stevens

STARTING GAGE HEIGHT: $11.0 \mathrm{ft}$.

ENDING GAGE HETER:

12-15-87

SUSP: Bag sampler and 300-1b weight

METER NO: P8308282 DATE RATED: 4-12-88

REMARKS: It was windy and cold. Transit rate was $12 \mathrm{~cm} / \mathrm{s}$ and the nozzle was $3 / 16$ inch. 3 Only upcast velocities are listed. The total discharge was $10,410 \mathrm{~m}^{3} / \mathrm{s}$.

\begin{tabular}{|c|c|c|c|c|c|c|c|c|}
\hline $\begin{array}{c}\text { Verti- } \\
\text { cal }\end{array}$ & $\begin{array}{l}\text { Distance } \\
\text { from } \\
\text { LEW } \\
\text { (m) }\end{array}$ & $\begin{array}{l}\text { Depth } \\
\text { (m) }\end{array}$ & $\begin{array}{c}\text { Mean } \\
\text { velocity } \\
\text { (m/s) }\end{array}$ & $\begin{array}{l}\text { Discharge } \\
\left(\mathrm{m}^{3} / \mathrm{s}\right)\end{array}$ & $\begin{array}{l}\text { Sample } \\
\text { volume } \\
(\mathrm{mL})\end{array}$ & $\begin{array}{l}\text { Temper- } \\
\text { ature } \\
\left({ }^{\circ} \mathrm{C}\right)\end{array}$ & $\mathrm{pH}$ & $\begin{array}{l}\text { Conductivity } \\
\text { (micro- } \\
\text { siemens } / \mathrm{cm})\end{array}$ \\
\hline LEW & 0 & 0.0 & 0.00 & 0 & -- & --- & -- & -- \\
\hline $01 \mathrm{~A}$ & 34 & 4.8 & 0.38 & 41 & 320 & 9.2 & 7.5 & 419 \\
\hline$x 01$ & 45 & 6.6 & 0.47 & 42 & -- & --- & -- & --- \\
\hline $02 \mathrm{~B}$ & 61 & 9.5 & 0.47 & 79 & 600 & 9.2 & 7.7 & 425 \\
\hline$x 02$ & 80 & 12.3 & 0.80 & 207 & -- & -- & -- & -- \\
\hline $03 \mathrm{~A}$ & 103 & 14.4 & 1.16 & 260 & 4980 & 8.9 & 7.6 & 419 \\
\hline$x 03$ & 111 & 14.6 & 1.27 & 268 & - & -- & - & -- \\
\hline $04 \mathrm{~B}$ & 132 & 14.3 & 1.28 & 365 & 4390 & 9.0 & 7.9 & 417 \\
\hline $\mathrm{X} 04$ & 151 & 13.7 & 1.32 & 208 & -- & --- & -- & --- \\
\hline $05 A$ & 155 & 13.3 & 1.31 & 409 & 5020 & 9.1 & 7.8 & 433 \\
\hline$\times 05$ & 179 & 13.3 & 1.50 & 140 & -- & $-\infty$ & -- & -- \\
\hline $06 \mathrm{~B}$ & 198 & 13.6 & 1.35 & 221 & 4230 & 8.9 & 7.6 & 427 \\
\hline$x 06$ & 212 & 13.6 & 1.47 & 449 & -- & --- & -- & -- \\
\hline $07 \mathrm{~A}$ & 224 & 13.5 & 1.46 & 295 & 5340 & 9.1 & 7.5 & 431 \\
\hline$x 07$ & 242 & 12.8 & 1.36 & 210 & -- & --- & -- & -- \\
\hline $08 \mathrm{~B}$ & 248 & 13.1 & 1.50 & 344 & 4390 & 8.8 & 7.7 & 439 \\
\hline $09 A$ & 277 & 13.2 & 1.47 & 659 & 4390 & 7.9 & 7.7 & 449 \\
\hline $10 \mathrm{~B}$ & 316 & 12.5 & 1.36 & 552 & 4650 & 8.5 & 7.7 & 441 \\
\hline $11 \mathrm{~A}$ & 342 & 11.7 & 1.37 & 464 & 3710 & 8.4 & 7.9 & 443 \\
\hline $12 \mathrm{~B}$ & 374 & 10.6 & 1.34 & 406 & 3470 & 8.7 & 7.7 & 445 \\
\hline $13 \mathrm{~A}$ & 399 & 10.9 & 1.23 & 423 & 3660 & 8.7 & 7.7 & 443 \\
\hline $14 \mathrm{~B}$ & 437 & 10.4 & 1.16 & 432 & 3210 & 9.0 & 7.5 & 441 \\
\hline $15 \mathrm{~A}$ & $4 i 1$ & 10.2 & 1.36 & 404 & 3080 & 8.1 & 7.7 & 451 \\
\hline $16 B$ & 495 & 10.2 & 1.04 & 302 & 2650 & 8.8 & 7.7 & 443 \\
\hline $17 \AA$ & 528 & 10.1 & 1.03 & 321 & 2410 & 9.0 & 7.6 & 441 \\
\hline $18 \mathrm{~B}$ & 557 & 10.0 & 1.07 & 326 & 2350 & 8.5 & 7.8 & 449 \\
\hline $19 \mathrm{~A}$ & 589 & 9.3 & 1.03 & 318 & 2430 & 9.0 & 7.7 & 455 \\
\hline $20 \mathrm{~B}$ & 623 & 8.9 & 1.11 & 320 & 2300 & 8.9 & 7.9 & 443 \\
\hline $21 \mathrm{~A}$ & 654 & 8.8 & 1.13 & 283 & 2350 & 9.0 & 7.9 & 443 \\
\hline $22 B$ & 680 & 8.8 & 0.95 & 267 & 2130 & 9.0 & 7.8 & 443 \\
\hline$=3 \mathrm{~A}$ & 718 & 8.0 & 0.98 & 275 & 1880 & 8.9 & 7.9 & 447 \\
\hline $24 \mathrm{~B}$ & 750 & 7.6 & 0.79 & 160 & 1300 & 8.9 & 7.9 & 443 \\
\hline $25 \mathrm{~A}$ & 771 & 5.6 & 0.85 & 162 & 1710 & 8.9 & 7.9 & 443 \\
\hline $26 \mathrm{~B}$ & 808 & 5.7 & 0.76 & 141 & 1070 & 8.9 & 7.9 & 449 \\
\hline $27 \mathrm{~A}$ & 836 & 5.5 & 0.75 & 132 & 710 & 9.0 & 7.9 & 449 \\
\hline $28 \mathrm{~B}$ & 872 & 4.9 & 0.57 & 92 & 740 & 8.9 & 8.0 & 443 \\
\hline $29 A$ & 902 & 4.3 & 0.55 & 70 & 480 & 9.0 & 7.9 & 447 \\
\hline
\end{tabular}


STATION: Misșissippi River below Vicksburg, Miss.

(cont inued)

\begin{tabular}{|c|c|c|c|c|c|c|c|c|}
\hline $\begin{array}{c}\text { Verti- } \\
\text { cal }\end{array}$ & $\begin{array}{c}\text { Distance } \\
\text { from } \\
\text { LEW } \\
\text { (m) }\end{array}$ & Depth & $\begin{array}{c}\text { Mean } \\
\text { velocity } \\
(\mathrm{m} / \mathrm{s})\end{array}$ & $\begin{array}{c}\text { Discharge } \\
\left(\mathrm{m}^{3} / \mathrm{s}\right)\end{array}$ & $\begin{array}{c}\text { Sample } \\
\text { volume } \\
(\mathrm{mL})\end{array}$ & $\begin{array}{c}\text { Temper- } \\
\text { ature } \\
\left({ }^{\circ} \mathrm{C}\right)\end{array}$ & $\mathrm{pH}$ & $\begin{array}{l}\text { Conductivity } \\
\text { (micro- } \\
\text { siemens } / \mathrm{cm} \text { ) }\end{array}$ \\
\hline $30 \mathrm{~B}$ & 931 & 4.0 & 0.54 & 64 & 370 & 9.0 & 8.0 & 449 \\
\hline $31 A$ & 961 & 3.3 & 0.58 & 63 & 350 & 8.9 & 7.9 & 447 \\
\hline $32 \mathrm{~B}$ & 997 & 3.2 & 0.37 & 40 & 310 & 9.0 & 8.0 & 445 \\
\hline $33 \mathrm{~A}$ & 1030 & 2.7 & 0.38 & 31 & 290 & 9.0 & 7.9 & 447 \\
\hline $34 \mathrm{~B}$ & 1058 & 2.9 & 0.51 & 47 & 270 & 9.0 & 7.9 & 447 \\
\hline $35 \mathrm{~A}$ & 1093 & 3.3 & 0.45 & 50 & 310 & 9.1 & 8.0 & 447 \\
\hline $36 \mathrm{~B}$ & 1125 & 3.7 & 0.46 & 52 & 350 & 9.2 & 8.0 & 447 \\
\hline REW & 1153 & 0.0 & 0.00 & 0 & -- & --- & -- & --- \\
\hline
\end{tabular}

${ }^{1}$ It has been assumed that the conductivity measurements were made without the temperature compensation switch on. The original conductivity measurements made at the temperatures listed above have been corrected to $25^{\circ} \mathrm{C}$. 


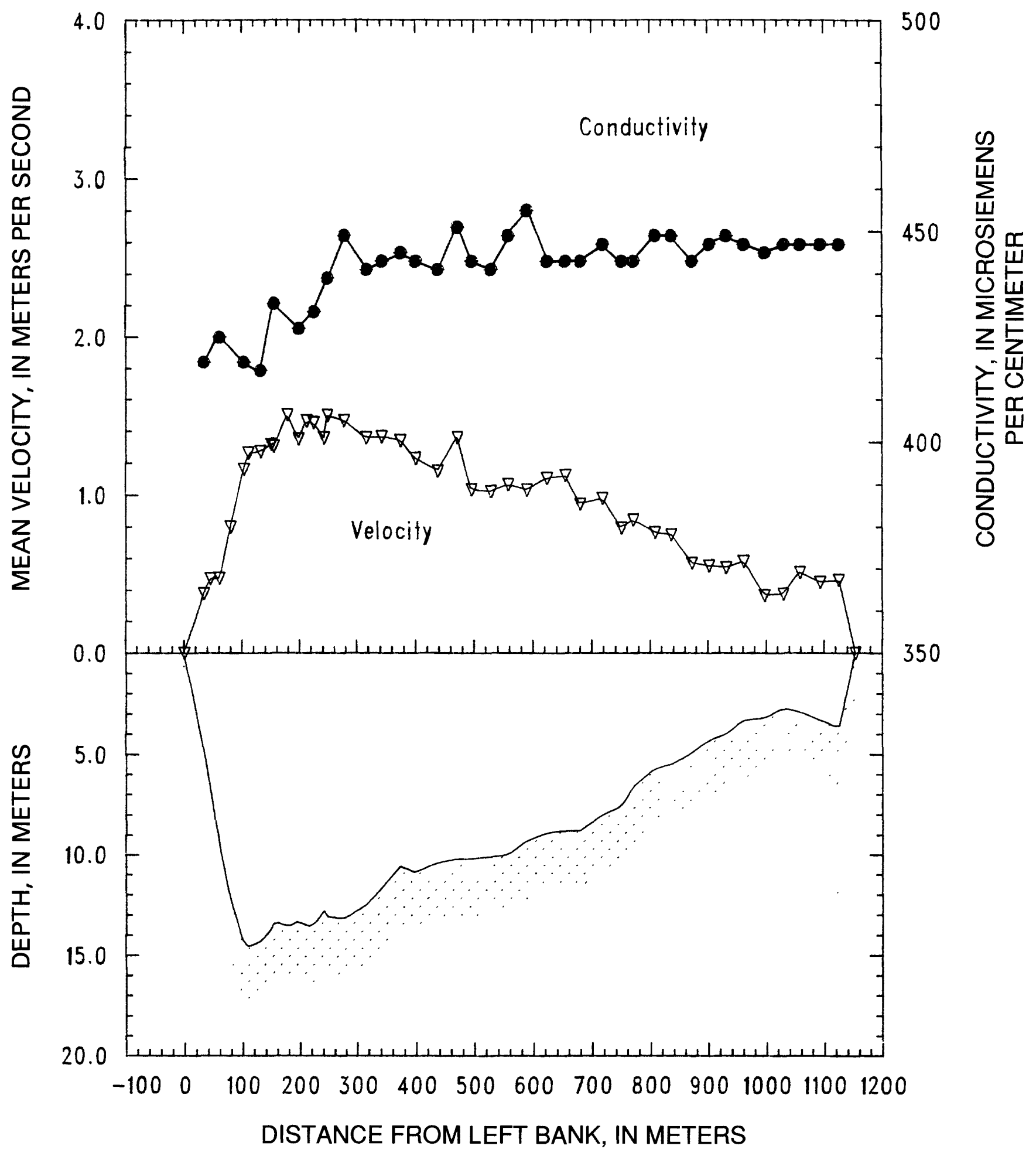

Figure 35. Mississippi River below Vicksburg, Miss. on December 15, 1987. 
STATION: Old River Outflow Channel near Knox Landing, La. $12-17-87$ PARTY: Black, Moody, and Stevens METER: SOLID CUP STARTING ARBITRARY GAGE HEIGHT: $0.20 \mathrm{~m}$ ENDING GAGE HEIGHT: $0.13 \mathrm{~m}$ SUSP: Bag sampler and $150-1 \mathrm{~b}$ weight

METER NO: P8308282 DATE RATED: 4-7-88

REMARKS: Anchored at verticals $3,5 \& 11$ and the verticals were not occupied in numerical order. Transit rate was $9 \mathrm{~cm} / \mathrm{s}$ and the nozzle was $5 / 16$ inch. Only the upcast velocities are listed. The total discharge was $1830 \mathrm{~m}^{3} / \mathrm{s}$.

\begin{tabular}{|c|c|c|c|c|c|c|c|c|}
\hline $\begin{array}{c}\text { Verti- } \\
\text { cal }\end{array}$ & $\begin{array}{c}\text { Distance } \\
\text { from } \\
\text { LEW } \\
(\mathrm{m})\end{array}$ & Depth & $\begin{array}{l}\text { Mean } \\
\text { velocity } \\
(m / s)\end{array}$ & $\begin{array}{c}\text { Discharge } \\
\left(\mathrm{m}^{3} / \mathrm{s}\right)\end{array}$ & $\begin{array}{c}\text { Sample } \\
\text { volume } \\
(\mathrm{mL})\end{array}$ & $\begin{array}{l}\text { Temper- } \\
\text { ature } \\
\left({ }^{\circ} \mathrm{C}\right)\end{array}$ & $\mathrm{pH}$ & $\begin{array}{l}\text { Conductivity } \\
\text { (micro- } \\
\text { siemens/cm) }\end{array}$ \\
\hline LEW & 0 & 0.0 & 0.00 & 0 & -- & --- & -- & --- \\
\hline $\mathrm{X} 04$ & 23 & 7.2 & 0.66 & 80 & -- & --- & -- & --- \\
\hline $13 \mathrm{~B}$ & 34 & 7.1 & 0.65 & 55 & 4490 & --- & -- & --- \\
\hline $13 \mathrm{~A}$ & 47 & 7.3 & 0.70 & 75 & 4400 & 9.3 & 8.0 & 449 \\
\hline $\mathrm{x} 03$ & 63 & 7.4 & 0.69 & 61 & -- & --- & -- & --- \\
\hline $12 \mathrm{~B}$ & 71 & 7.2 & 0.59 & 36 & 4530 & --- & -- & --- \\
\hline $12 \mathrm{~A}$ & 80 & 7.3 & 0.65 & 64 & 4440 & 9.1 & 8.0 & 455 \\
\hline $\mathrm{X} 01$ & 98 & 6.8 & 0.73 & 70 & -- & --- & -- & --- \\
\hline $11 \mathrm{~B}$ & 108 & 6.9 & 0.66 & -- & 7890 & & & \\
\hline $11 \mathrm{~A}$ & 108 & 6.9 & 0.66 & 75 & 8190 & 9.1 & 8.1 & 455 \\
\hline $\mathrm{x} 02$ & 131 & 6.6 & 0.69 & 98 & -- & --- & -- & --- \\
\hline $10 B$ & 151 & 6.4 & 0.71 & -- & 3140 & --- & -- & -- \\
\hline $10 \mathrm{~A}$ & 151 & 6.4 & 0.71 & 134 & 3460 & 9.1 & 8.0 & 449 \\
\hline $09 B$ & 190 & 6.5 & 0.65 & -- & 3710 & --- & -- & --- \\
\hline $09 \mathrm{~A}$ & 190 & 6.5 & 0.65 & 132 & 3780 & 9.1 & 8.0 & 449 \\
\hline $08 \mathrm{~A}$ & 213 & 6.2 & 0.63 & 70 & 3040 & 9.3 & 8.1 & 450 \\
\hline $08 \mathrm{~B}$ & 226 & 6.3 & 0.60 & 74 & 3700 & 9.1 & 8.0 & 450 \\
\hline 07B & 252 & 5.9 & 0.61 & 58 & 5780 & --- & -- & --- \\
\hline $07 \mathrm{~A}$ & 258 & 6.0 & 0.54 & 68 & 5590 & 9.0 & 8.0 & 456 \\
\hline $06 \mathrm{~A}$ & 294 & 5.3 & 0.67 & 74 & 2230 & --- & -- & --- \\
\hline $06 \mathrm{~B}$ & 300 & 5.1 & 0.60 & 52 & 2080 & -- & -- & --- \\
\hline 05B & 328 & 4.7 & 0.55 & -- & 2060 & --- & -- & --- \\
\hline $05 \mathrm{~A}$ & 328 & 4.7 & 0.55 & 92 & 1800 & 9.5 & 7.9 & 455 \\
\hline $04 \mathrm{~B}$ & 371 & 4.9 & 0.58 & -- & 2490 & --- & -- & -- \\
\hline $04 \mathrm{~A}$ & 371 & 4.9 & 0.58 & 118 & 2400 & 8.9 & 8.0 & 446 \\
\hline 03B & 410 & 5.2 & 0.57 & -- & 4750 & --- & -- & --- \\
\hline $03 \mathrm{~A}$ & 410 & 5.2 & 0.57 & 106 & 4320 & 9.3 & 8.0 & 453 \\
\hline $02 \mathrm{~A}$ & 442 & 5.3 & 0.63 & 66 & 2990 & 8.9 & 8.0 & 457 \\
\hline 02B & 450 & 5.1 & 0.60 & 65 & 2220 & --- & -- & -- \\
\hline $01 \mathrm{~B}$ & 485 & 5.0 & 0.57 & -- & 3170 & --- & -- & --- \\
\hline $01 \mathrm{~A}$ & 485 & 5.0 & 0.57 & 107 & 2440 & 8.9 & 7.9 & 457 \\
\hline REW & 525 & 0.0 & 0.00 & 0 & -- & --- & -- & --- \\
\hline
\end{tabular}




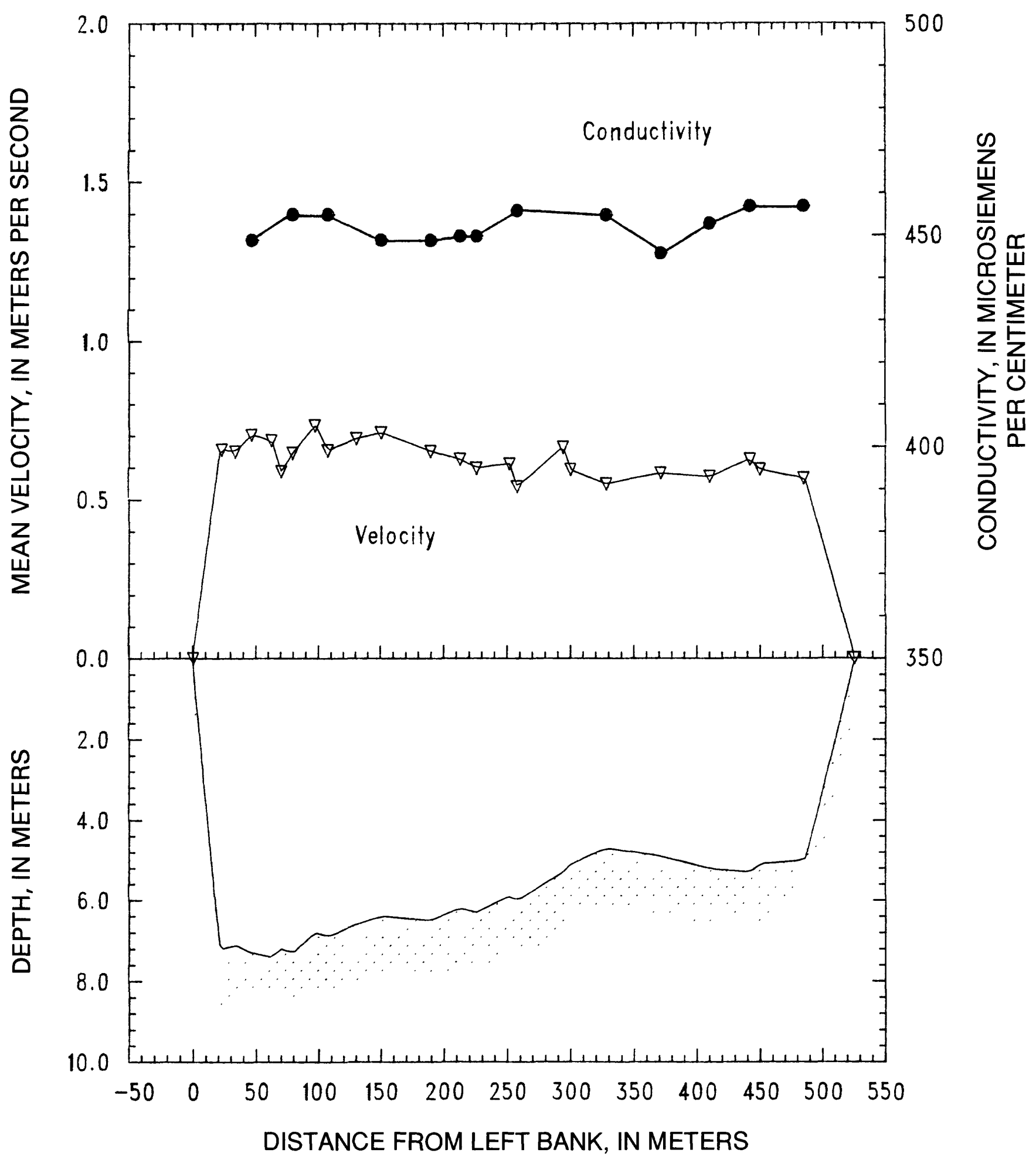

Figure 36. Old River Outflow Channel near Knox Landing, La. on December 17, 1987. 
STATION: Mississippi River near St. Francisville, La. $12-18-87$ PARTY: Black, Moody, and Stevens STARTING GAGE HEIGHT: TRDTH GAGE HEIGHT:

SUSP: Bag sampler and $150-1 \mathrm{~b}$ weight

METER NO: P8308282 DATE RATED: 4-7-88

REMARKS: Transit rate was $14 \mathrm{~cm} / \mathrm{s}$ and the nozzle was $1 / 4$ inch. Only the upcast velocities are listed. The total discharge was $8,180 \mathrm{~m}^{3} / \mathrm{s}$.

\begin{tabular}{|c|c|c|c|c|c|c|c|c|}
\hline $\begin{array}{l}\text { Verti- } \\
\text { cal }\end{array}$ & $\begin{array}{c}\text { Distance } \\
\text { from } \\
\text { LEW } \\
\text { (m) }\end{array}$ & Depth & $\begin{array}{c}\text { Mean } \\
\text { velocity } \\
(\mathrm{m} / \mathrm{s})\end{array}$ & $\begin{array}{c}\text { Discharge } \\
\left(\mathrm{m}^{3} / \mathrm{s}\right)\end{array}$ & $\begin{array}{l}\text { Sample } \\
\text { voiume } \\
(\mathrm{mL})\end{array}$ & $\begin{array}{l}\text { Temper- } \\
\text { ature } \\
\left({ }^{\circ} \mathrm{C}\right)\end{array}$ & $\mathrm{pH}$ & $\begin{array}{l}\text { Conductivity } \\
\text { (micro- } \\
\text { siemens } / \mathrm{cm} \text { ) }\end{array}$ \\
\hline LEW & 0 & 0.0 & 0.00 & 0 & -- & -- & -- & -- \\
\hline $32 \mathrm{~B}$ & 34 & 3.7 & 0.49 & 54 & 590 & 8.8 & 7.8 & 433 \\
\hline $31 \mathrm{~A}$ & 60 & 4.3 & 0.63 & 74 & 830 & 8.8 & 7.8 & 435 \\
\hline $30 \mathrm{~B}$ & 88 & 4.9 & 0.71 & 107 & 1270 & 8.8 & 7.8 & 433 \\
\hline $29 A$ & 122 & 6.2 & 0.78 & 132 & 1580 & 8.8 & 7.8 & 434 \\
\hline $28 \mathrm{~B}$ & 143 & 6.7 & 0.81 & 148 & 1800 & 8.8 & 7.8 & 435 \\
\hline $27 A$ & 177 & 7.5 & 0.79 & 257 & 2060 & 8.8 & 7.8 & 444 \\
\hline $26 B$ & 230 & 7.4 & 0.71 & 151 & 2390 & 8.7 & 8.0 & 445 \\
\hline $25 A$ & 234 & 7.4 & 0.65 & 101 & 2190 & 8.8 & 7.8 & 435 \\
\hline $24 B$ & 272 & 7.0 & 0.66 & 144 & 1920 & 8.7 & 8.1 & 447 \\
\hline $23 A$ & 296 & 8.1 & 0.68 & 135 & 2090 & 8.7 & 8.1 & 435 \\
\hline $22 B$ & 321 & 7.8 & 0.77 & 176 & 2200 & 8.7 & 7.9 & 435 \\
\hline $21 \mathrm{~A}$ & 355 & 7.9 & 0.74 & 200 & 2410 & 8.7 & 7.9 & 439 \\
\hline $20 \mathrm{~B}$ & 389 & 8.8 & 0.80 & 205 & 3200 & 8.7 & 7.9 & 436 \\
\hline $19 \mathrm{~A}$ & 413 & 8.8 & 0.99 & 240 & 3010 & 8.7 & 7.9 & 437 \\
\hline $18 \mathrm{~B}$ & 444 & 9.2 & 0.99 & 264 & 3500 & -- & -- & -- \\
\hline $17 A$ & 471 & 9.6 & 0.98 & 291 & 3400 & 8.7 & 7.9 & 435 \\
\hline $16 \mathrm{~B}$ & 506 & 9.4 & 1.03 & 315 & 3930 & 8.6 & 7.9 & 437 \\
\hline $15 \mathrm{~A}$ & 536 & 9.6 & 1.03 & 257 & 3570 & 8.6 & 7.9 & 443 \\
\hline $14 \mathrm{~B}$ & 558 & 9.8 & 1.05 & 293 & 4180 & 8.6 & 7.9 & 434 \\
\hline $13 \mathrm{~A}$ & 593 & 10.5 & 1.11 & 354 & 4910 & 8.6 & 7.9 & 431 \\
\hline $12 \mathrm{~B}$ & 619 & 10.7 & 1.09 & 314 & 4520 & 8.6 & 7.9 & 436 \\
\hline $11 \mathrm{~A}$ & 647 & 10.8 & 1.18 & 382 & 4830 & 8.6 & 7.8 & 445 \\
\hline $10 \mathrm{~B}$ & 679 & 10.8 & 1.14 & 374 & 5120 & 8.7 & 7.7 & 441 \\
\hline $09 A$ & 708 & 11.2 & 1.11 & 353 & 4870 & 8.7 & 7.7 & 445 \\
\hline $08 \mathrm{~B}$ & 736 & 12.4 & 1.14 & 366 & 5190 & 8.7 & 7.7 & 435 \\
\hline $07 \mathrm{~A}$ & 760 & 13.5 & 1.02 & 268 & 5080 & 8.7 & 7.7 & 435 \\
\hline $\mathrm{X} 04$ & 775 & 13.4 & 0.98 & 237 & -- & --- & -- & --- \\
\hline $06 \mathrm{~B}$ & 796 & 13.7 & 0.99 & 190 & 5330 & 8.8 & 7.8 & 441 \\
\hline $\mathrm{x} 03$ & 803 & 14.0 & 0.98 & 199 & -- & --- & -- & --- \\
\hline $05 \mathrm{~A}$ & 825 & 14.0 & 0.90 & 239 & 5670 & 8.8 & 7.8 & 445 \\
\hline $\mathrm{X02}$ & 841 & 13.7 & 0.98 & 196 & -- & --- & -- & -- \\
\hline $04 \mathrm{~B}$ & 854 & 13.3 & 0.96 & 153 & 4910 & 8.9 & 7.7 & 435 \\
\hline $\mathrm{x} 01$ & 865 & 13.2 & 0.91 & 161 & -- & --- & -- & --- \\
\hline $03 \mathrm{~A}$ & 881 & 13.1 & 0.96 & 277 & 4430 & 8.9 & 7.7 & 435 \\
\hline $02 \mathrm{~B}$ & 909 & 11.9 & 0.97 & 330 & 3990 & 8.9 & 7.7 & 445 \\
\hline $01 \mathrm{~A}$ & 938 & 9.8 & 0.81 & 243 & 2940 & --- & -- & -- \\
\hline REW & 970 & 0.0 & 0.00 & 0 & -- & --- & -- & --- \\
\hline
\end{tabular}




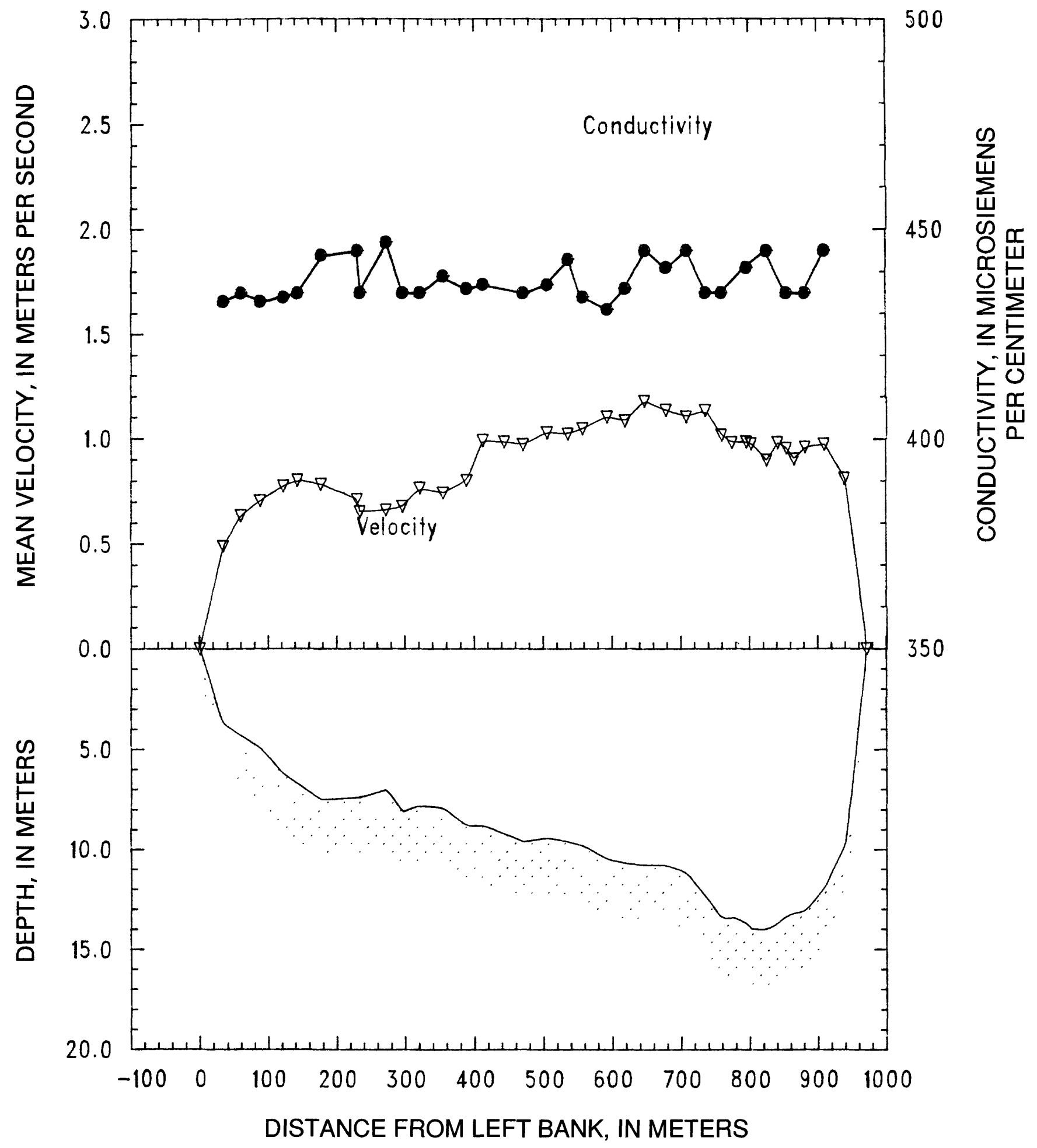

Figure 37. Mississippi River near St. Francisville, La. on December 18, 1987. 
STATION: Mississippi River below Belle Chasse, La.

PARTY: Black, Moody, and Stevens

STARTING GAGE HEIGHT:

ENDING GAGE HEIGHT:

12-20-87

SUSP: Bag sampler and 150-1b weight

METER No: P8308282

DATE RATED: 4-7-88

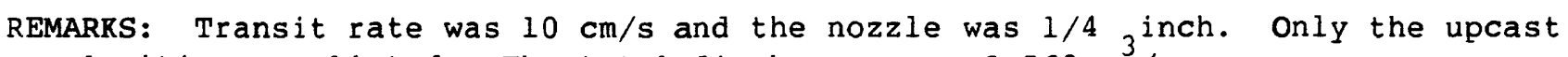
velocities are 1 isted. The total discharge was $9,560 \mathrm{~m}^{3} / \mathrm{s}$.

\begin{tabular}{|c|c|c|c|c|c|c|c|c|}
\hline $\begin{array}{l}\text { Verti- } \\
\text { cal }\end{array}$ & $\begin{array}{c}\text { Distance } \\
\text { from } \\
\text { LEW } \\
\text { (m) }\end{array}$ & Depth & $\begin{array}{c}\text { Mean } \\
\text { velocity } \\
(\mathrm{m} / \mathrm{s})\end{array}$ & $\begin{array}{c}\text { Discharge } \\
\left(\mathrm{m}^{3} / \mathrm{s}\right)\end{array}$ & $\begin{array}{c}\text { Sample } \\
\text { volume } \\
(\mathrm{mL})\end{array}$ & $\begin{array}{l}\text { Temper- } \\
\text { ature } \\
\left({ }^{\circ} \mathrm{C}\right)\end{array}$ & $\mathrm{pH}$ & $\begin{array}{l}\text { Conductivity } \\
\text { (micro- } \\
\text { siemens/cm) }\end{array}$ \\
\hline LEW & 0 & 0.0 & 0.00 & 0 & - & -- & -- & -- \\
\hline $20 \mathrm{~B}$ & 37 & 9.9 & 0.44 & 153 & 1330 & 12.3 & 7.9 & 497 \\
\hline $19 \mathrm{~A}$ & 70 & 15.2 & 0.49 & 258 & 2660 & 12.3 & 7.9 & 495 \\
\hline $18 B$ & 106 & 19.8 & 0.60 & 466 & 4620 & 11.4 & 7.9 & 495 \\
\hline $17 A$ & 148 & 21.3 & 0.66 & 566 & 6000 & 11.9 & 7.8 & 497 \\
\hline $16 \mathrm{~B}$ & 186 & 21.3 & 0.71 & 664 & 6620 & 17.0 & 7.9 & 495 \\
\hline $15 \mathrm{~A}$ & 236 & 22.8 & 0.73 & 629 & 6820 & 17.0 & 7.9 & 492 \\
\hline $14 \mathrm{~B}$ & 262 & 24.3 & 0.72 & 554 & 6790 & 16.6 & 7.9 & 491 \\
\hline $13 \mathrm{~A}$ & 299 & 24.3 & 0.65 & 572 & 4430 & 16.6 & 7.9 & 487 \\
\hline $12 \mathrm{~B}$ & 335 & 23.8 & 0.68 & 617 & 6370 & 16.6 & 7.9 & 489 \\
\hline $11 \mathrm{~A}$ & 375 & 24.2 & 0.69 & 386 & -- & --- & -- & -- \\
\hline $11 \mathrm{~A}$ & 381 & 23.9 & 0.68 & 219 & 5380 & 16.6 & 7.9 & 489 \\
\hline $10 \mathrm{~B}$ & 402 & 23.6 & 0.66 & 496 & 6490 & 11.3 & 7.8 & 497 \\
\hline $09 A$ & 445 & 24.0 & 0.65 & 652 & 5950 & 12.7 & 8.0 & 494 \\
\hline $08 B$ & 485 & 23.6 & 0.62 & 569 & 5540 & 13.0 & 8.0 & 495 \\
\hline $07 \mathrm{~A}$ & 523 & 23.0 & 0.57 & 446 & 5090 & 11.5 & 8.0 & 494 \\
\hline $06 \mathrm{~B}$ & 553 & 22.8 & 0.57 & 430 & 4810 & 11.5 & 7.6 & 497 \\
\hline $05 A$ & 589 & 23.2 & 0.52 & 475 & 4020 & 11.0 & 8.0 & 495 \\
\hline $04 \mathrm{~B}$ & 631 & 23.1 & 0.50 & 482 & 4880 & 10.7 & 8.0 & 495 \\
\hline $03 \mathrm{~A}$ & 672 & 21.2 & 0.50 & 374 & 3980 & 11.3 & 8.0 & 500 \\
\hline $02 B$ & 702 & 21.4 & 0.50 & 305 & 4020 & 11.3 & 8.0 & 499 \\
\hline $01 \mathrm{~A}$ & 729 & 15.6 & 0.42 & 245 & 3110 & 11.3 & 8.0 & 497 \\
\hline REW & 776 & 0.0 & 0.00 & 0 & -- & --- & -- & --- \\
\hline
\end{tabular}




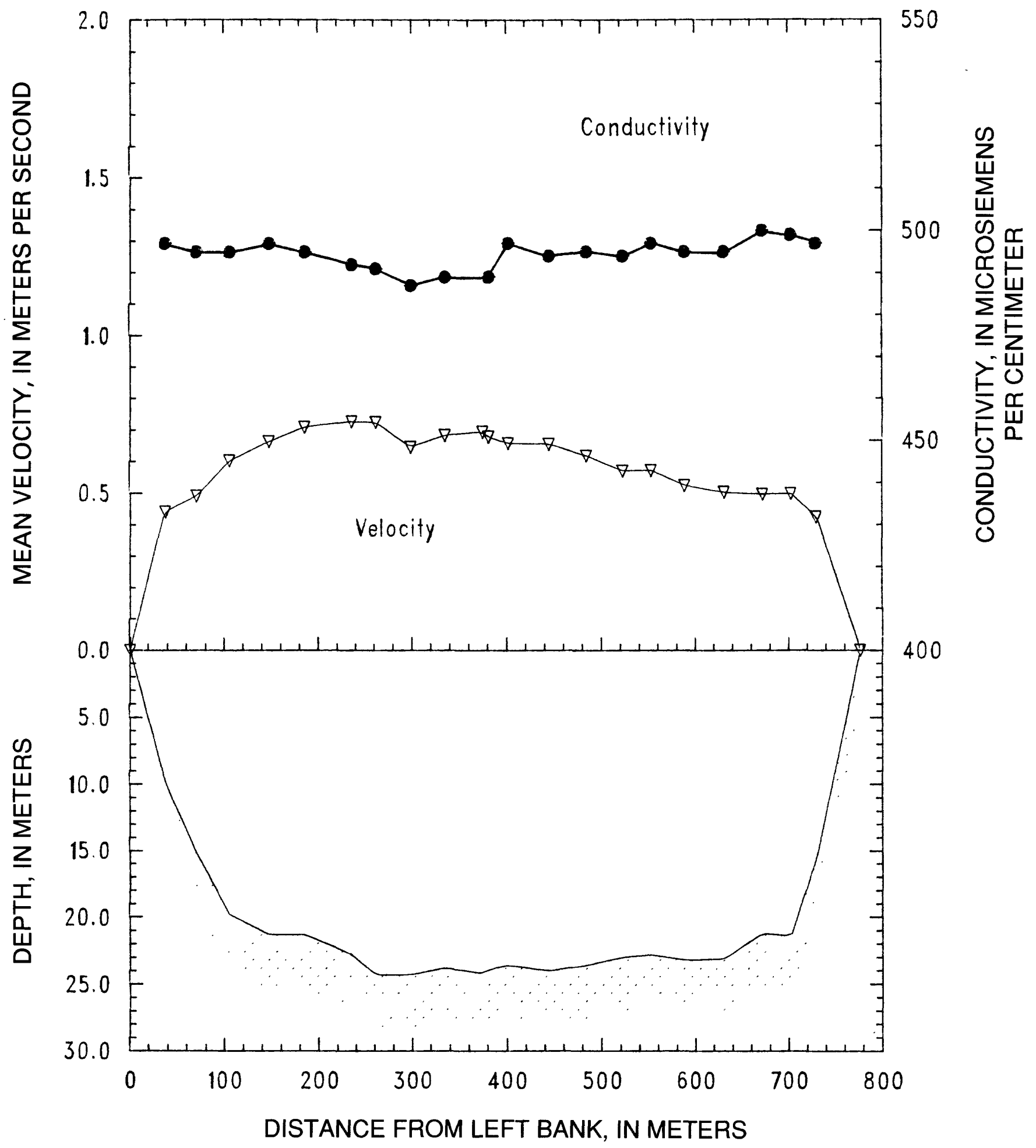

Figure 38. Mississippi River below Belle Chasse, La. on December 20, 1987. 


\section{DATA LISTINGS}

FOR

MAY 16 - JUNE 7, 1988

CRUISE 
STATION: Mississippi River near Winfield, Mo.

PARTY: Black, Moody, and Rees

STARTING GAGE HEIGHT: $422.33 \mathrm{ft}$

5-17-88

SUSP: Bag sampler and 200-1b weight

METER No: P8308282 DATE RATED: 6-28-88

REMARKS: Transit rate 3 was $4 \mathrm{~cm} / \mathrm{s}$ and the nozzle was $1 / 4$ inch. The total discharge was $1740 \mathrm{~m}^{3} / \mathrm{s}$.

\begin{tabular}{|c|c|c|c|c|c|c|c|c|c|}
\hline \multirow{3}{*}{$\begin{array}{c}\text { Verti- } \\
\text { cal }\end{array}$} & \multirow{3}{*}{$\begin{array}{l}\text { Dist. } \\
\text { from } \\
\text { LEW } \\
\text { (m) }\end{array}$} & \multirow{3}{*}{$\begin{array}{l}\text { Depth } \\
\text { (m) }\end{array}$} & \multirow{3}{*}{$\begin{array}{l}\text { Mean } \\
\text { velocity } \\
(\mathrm{m} / \mathrm{s})\end{array}$} & \multirow{3}{*}{$\begin{array}{l}\text { Discharge } \\
\left(\mathrm{m}^{3} / \mathrm{s}\right)\end{array}$} & \multicolumn{2}{|c|}{ Volume } & \multirow{3}{*}{$\begin{array}{l}\text { Temper- } \\
\text { ature } \\
\left({ }^{\circ} \mathrm{C}\right)\end{array}$} & \multirow{3}{*}{$\mathrm{pH}^{1}$} & \multirow{3}{*}{$\begin{array}{l}\text { Conductivity } \\
\text { (micro- } \\
\text { siemens/cm) }\end{array}$} \\
\hline & & & & & Vi & $V p$ & & & \\
\hline & & & & & $(\mathrm{mL})$ & $(L)$ & & & \\
\hline LEW & 0 & 0.0 & 0.00 & 0 & -- & -- & -- & -- & --- \\
\hline $01 A$ & 30 & 7.2 & 0.46 & 64 & 2060 & 11 & 20.6 & 8.5 & 422 \\
\hline $02 \mathrm{~B}$ & 39 & 7.3 & 0.46 & 28 & 1880 & 21 & 20.2 & 8.3 & 419 \\
\hline $03 \mathrm{~A}$ & 47 & 8.2 & 0.57 & 72 & 5090 & 26 & 20.2 & 8.5 & 420 \\
\hline $04 \mathrm{~B}$ & 70 & 8.6 & 0.68 & 108 & 6410 & 27 & 20.4 & 8.6 & 417 \\
\hline $05 \mathrm{~A}$ & 84 & 8.4 & 0.71 & 124 & 6290 & 28 & 20.6 & 8.6 & 417 \\
\hline 06B & 112 & 8.0 & 0.67 & 118 & 6120 & 27 & 20.2 & 8.6 & 415 \\
\hline $07 A$ & 128 & 8.2 & 0.68 & 116 & 6280 & 27 & 20.8 & 8.5 & 416 \\
\hline $08 \mathrm{~B}$ & 154 & 7.9 & 0.64 & 86 & 5060 & 27 & 20.7 & 8.5 & 414 \\
\hline $09 A$ & 162 & 7.8 & 0.63 & 41 & 5740 & 25 & 19.8 & 8.1 & 413 \\
\hline $10 \mathrm{~B}$ & 171 & 7.8 & 0.63 & 54 & 4400 & 24 & 21.2 & 7.5 & 415 \\
\hline $10 \mathrm{C}$ & 184 & 7.6 & 0.55 & 54 & -- & -- & -- & -- & --- \\
\hline $11 \mathrm{~A}$ & 197 & 7.4 & 0.57 & 72 & 4810 & 23 & 21.6 & 8.3 & 416 \\
\hline $12 \mathrm{~B}$ & 218 & 7.0 & 0.60 & 83 & 4390 & 23 & 21.8 & 8.2 & 416 \\
\hline $13 \mathrm{~A}$ & 236 & 6.8 & 0.57 & 60 & 4240 & 20 & 21.1 & 8.3 & 417 \\
\hline $14 \mathrm{~B}$ & 249 & 6.5 & 0.59 & 59 & 3600 & 20 & 21.2 & 8.3 & 419 \\
\hline $15 \mathrm{~A}$ & 267 & 6.5 & 0.55 & 68 & 3980 & 19 & 22.6 & 8.3 & 424 \\
\hline $16 \mathrm{~B}$ & 287 & 6.1 & 0.50 & 46 & -- & -- & -- & -- & --- \\
\hline $16 \mathrm{R}$ & 297 & 6.0 & 0.49 & 41 & 2850 & 17 & 22.3 & 8.2 & 425 \\
\hline $17 \mathrm{~A}$ & 315 & 5.6 & 0.50 & 41 & 2350 & 15 & 21.4 & 8.2 & 428 \\
\hline $18 \mathrm{~B}$ & 326 & 5.4 & 0.53 & 26 & 1960 & 13 & 21.4 & 8.2 & 421 \\
\hline $19 \mathrm{~A}$ & 333 & 5.3 & 0.48 & 43 & 2500 & 13 & 22.3 & 8.3 & 429 \\
\hline $20 B$ & 360 & 4.8 & 0.46 & 54 & 1650 & 11 & 21.2 & 8.4 & 424 \\
\hline $21 \mathrm{~A}$ & 382 & 4.6 & 0.47 & 49 & 2040 & 11 & 23.0 & 8.4 & 424 \\
\hline $22 \mathrm{~B}$ & 405 & 4.5 & 0.49 & 29 & 1220 & 10 & 22.6 & 8.4 & 418 \\
\hline $23 A$ & 408 & 4.3 & 0.50 & 25 & 1940 & 9 & 22.4 & 8.4 & 427 \\
\hline $24 B$ & 428 & 4.0 & 0.53 & 34 & 1180 & 8 & 22.6 & 8.4 & 423 \\
\hline $25 A$ & 440 & 4.0 & 0.45 & 32 & 1410 & 8 & 21.5 & 8.3 & 425 \\
\hline $26 B$ & 463 & 3.8 & 0.42 & 29 & 1120 & 9 & 21.2 & 8.3 & 418 \\
\hline $27 \mathrm{~A}$ & 476 & 3.8 & 0.37 & 27 & 1170 & 8 & 22.0 & 8.3 & 425 \\
\hline $28 B$ & 501 & 3.7 & 0.35 & 24 & 860 & 6 & 21.8 & 8.3 & 428 \\
\hline $29 A$ & 514 & 4.0 & 0.28 & 17 & 340 & 8 & 22.6 & 8.3 & 433 \\
\hline $30 \mathrm{~B}$ & 531 & 3.8 & 0.29 & 18 & 680 & 7 & 22.2 & 8.3 & 425 \\
\hline REW & 547 & 0.0 & 0.00 & 0 & -- & -- & -- & -- & --- \\
\hline
\end{tabular}

${ }^{1} \mathrm{pH}$ meter drifted so that the $\mathrm{pH}$ values have been corrected by linear interpolation between five readings in a standard $\mathrm{pH} 7$ buffer solution. 


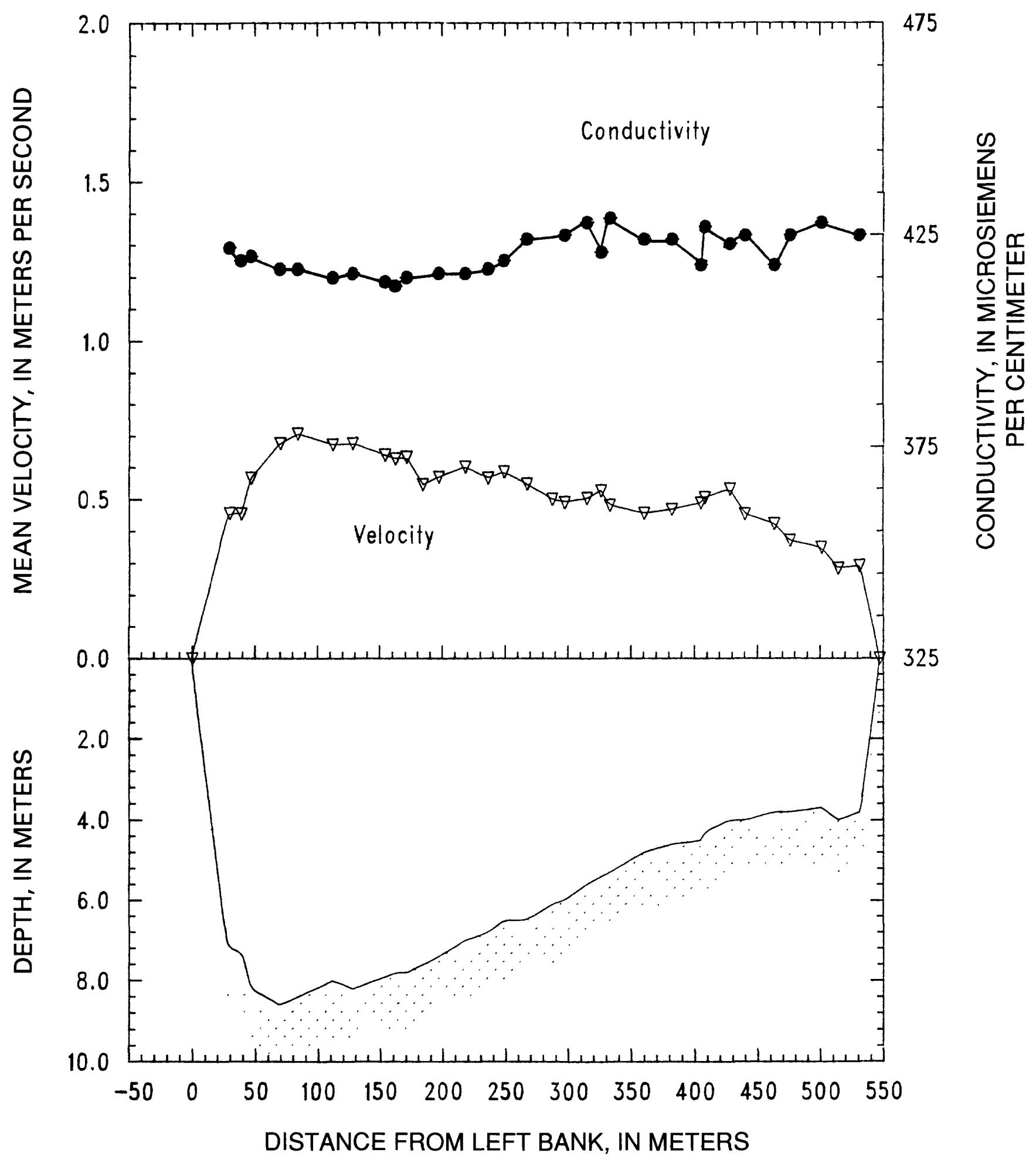

Figure 39. Mississippi River near Winfield, Mo. on May 17, 1988. 
STATION: Illinois River below Meredosia, Ill.

PARTY: Black, Moody, and Rees

$5-16-88$

STARTING GAGE HEIGHT: $422.08 \mathrm{ft}$

METER: SOLID CUP

SUSP: Bag sampler and 200-1b weight

METER NO: P8308282 DATE RATED: 6-28-88

REMARKS: Transit rate was $7 \mathrm{~cm} / \mathrm{s}$ and no nozzle was used in the sampling bottle The vessel was anchored at each vertical in the following order: 14,13,12, $1+2+3,31,10,9,4,16,15,17,18,19+20,5,6,7$, and 8 . The total discharge was $332 \mathrm{~m}^{3} / \mathrm{s}$.

\begin{tabular}{|c|c|c|c|c|c|c|c|c|c|}
\hline \multirow{3}{*}{$\begin{array}{l}\text { Verti- } \\
\text { cal }\end{array}$} & \multirow{2}{*}{$\begin{array}{l}\text { Dist. } \\
\text { from }\end{array}$} & \multirow[t]{2}{*}{ Depth } & \multirow{2}{*}{$\begin{array}{l}\text { Mean } \\
\text { velocity }\end{array}$} & \multirow{2}{*}{ Discharge } & \multicolumn{2}{|c|}{ Volume } & \multirow{2}{*}{$\begin{array}{l}\text { Temper- } \\
\text { ature }\end{array}$} & \multirow[t]{2}{*}{$\mathrm{pH}^{2}$} & \multirow[t]{2}{*}{ Conductivity } \\
\hline & & & & & $V i$ & $V p$ & & & \\
\hline & $\begin{array}{l}\text { LEW } \\
(\mathrm{m})\end{array}$ & (m) & $(\mathrm{m} / \mathrm{s})$ & $\left(m^{3} / s\right)$ & $(\mathrm{mL})$ & (L) & $\left({ }^{\circ} \mathrm{C}\right)$ & & $\begin{array}{l}\text { (micro- } \\
\text { siemens } / \mathrm{cm} \text { ) }\end{array}$ \\
\hline
\end{tabular}

$\begin{array}{lrrrrrrrrr}\text { LEW } & 0 & 0.0 & 0.00 & 0 & -- & -- & -- & -- & --- \\ \text { 03B } & 30 & 2.2 & 0.22 & 10 & 2780 & 11 & 21.7 & 8.2 & 759 \\ \text { 04A } & 44 & 1.9 & 0.37 & 8 & 3490 & 6 & 22.3 & 8.1 & 760 \\ \text { 05B } & 52 & 2.0 & 0.29 & 7 & 3060 & 7 & 22.6 & 8.0 & 754 \\ \text { 06A } & 68 & 2.8 & 0.35 & 12 & 5770 & 15 & 22.6 & 8.1 & 755 \\ \text { 07B } & 76 & 3.2 & 0.41 & 9 & 6500 & 20 & 22.6 & 8.1 & 751 \\ \text { 08A } & 82 & 3.3 & 0.40 & 13 & 7440 & 22 & 22.9 & 8.3 & 762 \\ \text { 09B } & 96 & 5.0 & 0.49 & 31 & 8590 & 37 & 22.3 & 7.9 & 767 \\ \text { 10A } & 107 & 5.4 & 0.43 & 29 & 12660 & 41 & 21.7 & 8.0 & 764 \\ \text { 11B } & 121 & 5.7 & 0.47 & 31 & 11070 & 41 & 21.7 & 8.0 & 759 \\ \text { 12A } & 130 & 5.6 & 0.43 & 28 & 13570 & 44 & 21.7 & 8.1 & 748 \\ \text { 13B } & 144 & 6.0 & 0.44 & 33 & 10000 & 48 & 21.7 & 8.2 & 747 \\ \text { 14A } & 155 & 6.1 & 0.41 & 30 & 12260 & 48 & 21.6 & 8.4 & 746 \\ \text { 15B } & 168 & 5.8 & 0.46 & 22 & 11200 & 45 & 22.3 & 8.1 & 751 \\ \text { 16A } & 172 & 5.7 & 0.39 & 21 & 11810 & 44 & 21.9 & 7.9 & 759 \\ \text { 17B } & 187 & 4.9 & 0.39 & 23 & 6870 & 37 & 22.4 & 7.9 & 750 \\ \text { 18A } & 196 & 3.7 & 0.33 & 10 & 5320 & 11 & 22.6 & 7.9 & 768 \\ \text { 19B } & 204 & 2.5 & 0.38 & 15 & 4190 & 15 & 22.5 & 8.0 & 753 \\ \text { REW } & 228 & 0.0 & 0.00 & 0 & -- & -- & -- & -- & ---\end{array}$

${ }^{1} \mathrm{pH}$ meter drifted so that the $\mathrm{pH}$ values have been corrected by linear interpolation between an initial and final calibration reading in a standard $\mathrm{pH} 7$ buffer solution. 


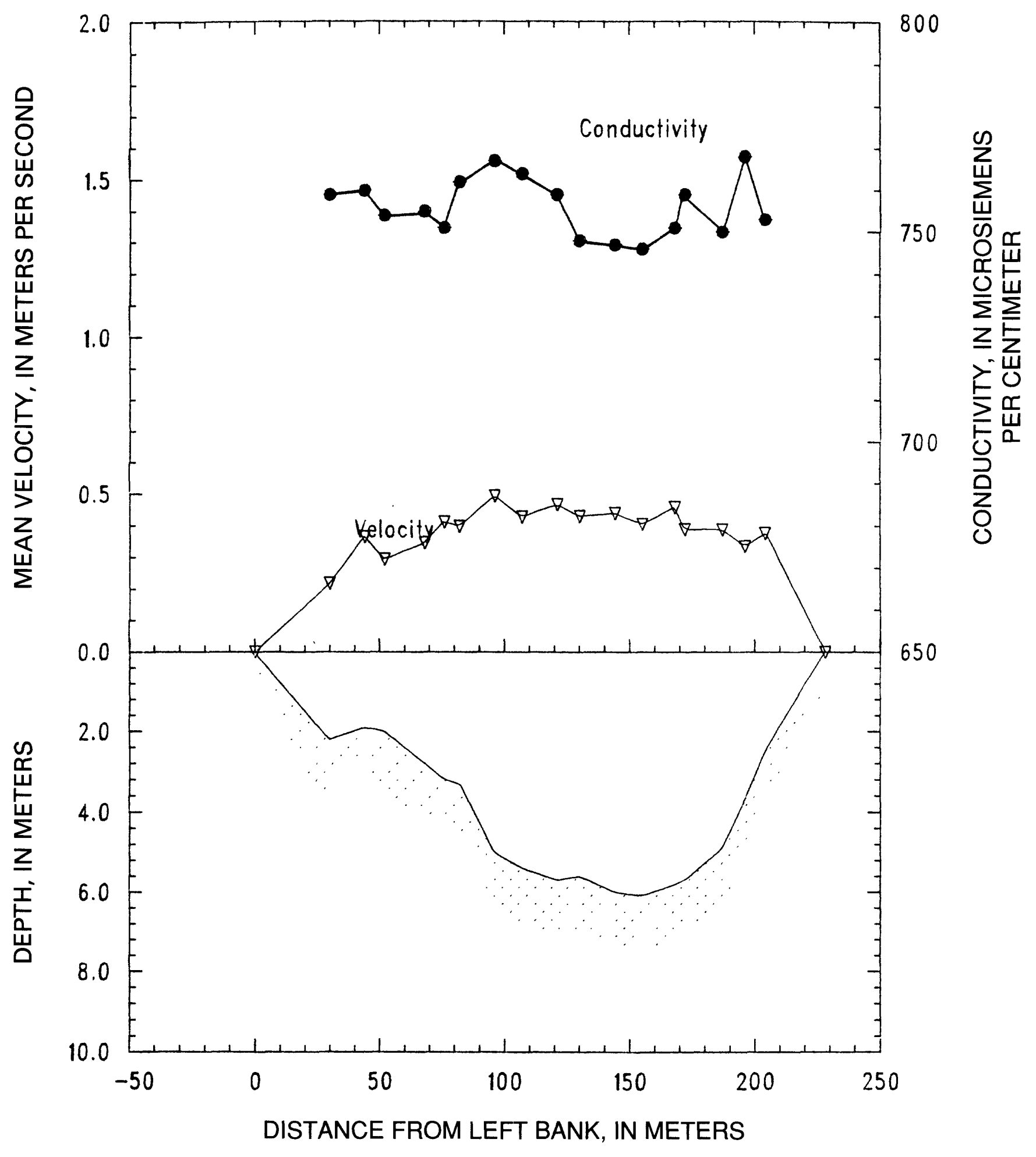

Figure 40. Illinois River below Meredosia, III. on May 16, 1988. 
STATION: Missouri River at Hermann, Mo.

PARTY: Black, Moody, and Rees

STARTING GAGE HEIGHT: $8.5 \mathrm{ft}$

5-19-88

SUSP: Bag sampler and 200-lb weight

METER NO: P8308282 DATE RATED: 6-28-88

REMARKS: Transit rate was $12 \mathrm{~cm} / \mathrm{sec}$ and the nozzle was $5 / 16$ inch. Verticals were occupied in the following order: $1-12,15,13,318,19,21-23,26,25,29,30,28$, $27,24,14,16,17,20$. The total discharge was $1480 \mathrm{~m}^{3} / \mathrm{s}$.

\begin{tabular}{|c|c|c|c|c|c|c|c|c|c|}
\hline \multirow{3}{*}{$\begin{array}{c}\text { Verti- } \\
\text { cal }\end{array}$} & \multirow{3}{*}{$\begin{array}{l}\text { Dist. } \\
\text { from } \\
\text { LEW } \\
(m)\end{array}$} & \multirow{3}{*}{$\begin{array}{l}\text { Depth } \\
\text { (m) }\end{array}$} & \multirow{3}{*}{$\begin{array}{l}\text { Mean } \\
\text { velocity } \\
(\mathrm{m} / \mathrm{s})\end{array}$} & \multirow{3}{*}{$\begin{array}{l}\text { Discharge } \\
\left(\mathrm{m}^{3} / \mathrm{s}\right)\end{array}$} & \multicolumn{2}{|c|}{ Volume } & \multirow{3}{*}{$\begin{array}{c}\text { Temper- } \\
\text { ature } \\
\left({ }^{\circ} \mathrm{C}\right)\end{array}$} & \multirow{3}{*}{$\mathrm{pH}^{1}$} & \multirow{3}{*}{$\begin{array}{l}\text { Conductivity } \\
\text { (micro- } \\
\text { siemens/cm) }\end{array}$} \\
\hline & & & & & $\mathrm{Vi}$ & $V p$ & & & \\
\hline & & & & & $(m L)$ & (L) & & & \\
\hline LEW & 0 & 0.0 & 0.00 & 0 & -- & -- & -- & -- & --- \\
\hline $0 I A$ & 13 & 6.7 & 0.26 & 23 & 1640 & 34 & 20.7 & 8.3 & 700 \\
\hline $02 \mathrm{~B}$ & 27 & 6.1 & 1.02 & 56 & 4460 & 21 & 21.0 & 8.3 & 725 \\
\hline $02 R$ & 31 & 6.1 & 1.07 & 29 & -- & -- & -- & -- & --- \\
\hline $03 A$ & 36 & 5.8 & 1.11 & 39 & 4450 & 25 & 21.7 & 8.3 & 749 \\
\hline X01 & 43 & 5.7 & 1.18 & 37 & -- & -- & -- & -- & --- \\
\hline $04 \mathrm{~B}$ & 47 & 5.8 & 1.00 & 29 & 4980 & 24 & 21.6 & 8.3 & 744 \\
\hline $\mathrm{X} 02$ & 53 & 5.5 & 0.99 & 25 & - & -- & - & - & -- \\
\hline $05 \mathrm{~A}$ & 56 & 5.3 & 0.95 & 30 & 3910 & 21 & 21.7 & 8.3 & 745 \\
\hline $\mathrm{x} 03$ & 65 & 5.3 & 1.16 & 43 & - & -- & - & -- & -- \\
\hline $06 \mathrm{~B}$ & 70 & 5.2 & 1.32 & 45 & 5020 & 22 & 21.7 & 8.2 & 741 \\
\hline $\mathrm{X} 04$ & 78 & 5.3 & 1.03 & 33 & -- & -- & -- & -- & --- \\
\hline $07 A$ & 82 & 5.4 & 0.87 & 30 & 3970 & 21 & 21.7 & 8.2 & 739 \\
\hline $08 B$ & 91 & 5.1 & 1.09 & 41 & 4940 & 22 & 21.9 & 8.1 & 727 \\
\hline X06 & 97 & 4.9 & 1.29 & 37 & -- & -- & -- & -- & --- \\
\hline 09A & 103 & 4.9 & 1.08 & 45 & 4460 & 19 & 21.7 & 8.2 & 729 \\
\hline $\mathrm{x} 07$ & 114 & 4.8 & 1.09 & 37 & -- & -- & -- & -- & --- \\
\hline $10 \mathrm{~B}$ & 117 & 4.9 & 0.90 & 15 & 4000 & 20 & 21.8 & 8.2 & 722 \\
\hline$x 08$ & 121 & 4.9 & 1.11 & 25 & -- & -- & -- & -- & --- \\
\hline $11 \mathrm{~A}$ & 126 & 4.7 & 1.01 & 31 & 4060 & 20 & 21.8 & 8.1 & 707 \\
\hline X09 & 134 & 5.0 & 1.11 & 36 & -- & -- & -- & -- & -- \\
\hline $12 \mathrm{~B}$ & 139 & 4.8 & 1.07 & 44 & 4590 & 18 & 21.7 & 8.2 & 696 \\
\hline $13 A$ & 151 & 5.1 & 1.02 & 49 & 4280 & 21 & 22.0 & 8.2 & 684 \\
\hline $14 \mathrm{~B}$ & 158 & 5.3 & 1.16 & 52 & 4340 & 26 & 22.3 & 8.3 & 680 \\
\hline $15 \mathrm{~A}$ & 168 & 5.3 & 1.04 & 72 & 3680 & 20 & 21.8 & 8.2 & 668 \\
\hline $16 \mathrm{~B}$ & 184 & 5.3 & 1.06 & 85 & 4290 & 21 & 22.4 & 8.3 & 681 \\
\hline $17 \mathrm{~A}$ & 198 & 4.9 & 1.12 & 98 & 3750 & 21 & 22.2 & 8.3 & 660 \\
\hline $18 \mathrm{~B}$ & 220 & 4.5 & 1.05 & 100 & 4090 & 22 & 22.0 & 8.2 & 663 \\
\hline $19 A$ & 220 & 4.5 & 1.05 & -- & 2780 & 16 & 21.9 & 8.2 & 650 \\
\hline $20 \mathrm{~B}$ & 240 & 3.7 & 1.14 & 74 & 3260 & 12 & 22.2 & 8.3 & 647 \\
\hline $21 A$ & 240 & 3.7 & 1.14 & -- & 2790 & 12 & 21.9 & 8.2 & 638 \\
\hline $22 \mathrm{~B}$ & 255 & 3.2 & 1.09 & 35 & 2310 & 10 & 21.9 & 8.2 & 642 \\
\hline
\end{tabular}




\begin{tabular}{|c|c|c|c|c|c|c|c|c|c|}
\hline \multirow{3}{*}{$\begin{array}{c}\text { Verti- } \\
\text { cal }\end{array}$} & \multirow{3}{*}{$\begin{array}{l}\text { Dist. } \\
\text { from } \\
\text { LEW } \\
\text { (m) }\end{array}$} & \multirow{3}{*}{$\begin{array}{l}\text { Depth } \\
\text { (m) }\end{array}$} & \multirow{3}{*}{$\begin{array}{l}\text { Mean } \\
\text { velocity } \\
(\mathrm{m} / \mathrm{s})\end{array}$} & \multirow{3}{*}{$\begin{array}{c}\text { Discharge } \\
\left(m^{3} / s\right)\end{array}$} & \multicolumn{2}{|c|}{ Volume } & \multirow{3}{*}{$\begin{array}{l}\text { Temper- } \\
\text { ature } \\
\left({ }^{\circ} \mathrm{C}\right)\end{array}$} & \multirow[t]{3}{*}{$\mathrm{pH}^{1}$} & \multirow{3}{*}{$\begin{array}{l}\text { Conductivity } \\
\text { (micro- } \\
\text { siemens } / \mathrm{cm} \text { ) }\end{array}$} \\
\hline & & & & & $V i$ & $V p$ & & & \\
\hline & & & & & $(\mathrm{mL})$ & (L) & & & \\
\hline $23 R$ & 260 & 2.7 & 0.89 & 12 & -- & - & -- & -- & --- \\
\hline $23 A$ & 265 & 2.7 & 0.93 & 19 & 1210 & 7 & 21.9 & 8.2 & 636 \\
\hline $24 B$ & 275 & 2.4 & 0.63 & 20 & 1360 & 6 & 22.3 & 8.2 & 660 \\
\hline $25 \mathrm{~A}$ & 291 & 2.5 & 0.73 & 29 & 1440 & 5 & 22.2 & 8.2 & 638 \\
\hline $26 B$ & 291 & 2.5 & 0.73 & -- & 1100 & 7 & 22.1 & 8.3 & 636 \\
\hline $27 A$ & 307 & 2.8 & 0.83 & 34 & 1320 & 7 & 22.4 & 8.3 & 648 \\
\hline $28 B$ & 320 & 2.7 & 0.66 & 21 & 620 & 7 & 22.2 & 8.3 & 640 \\
\hline $29 A$ & 330 & 2.9 & 0.52 & 15 & 1020 & 7 & 22.1 & 8.2 & 636 \\
\hline $30 \mathrm{~B}$ & 340 & 3.1 & 0.46 & 14 & 730 & 9 & 22.2 & 8.3 & 644 \\
\hline REW & 350 & 0.0 & 0.00 & 0 & -- & -- & -- & -- & --- \\
\hline
\end{tabular}

${ }^{1} \mathrm{pH}$ meter drifted so that the $\mathrm{pH}$ values have been corrected by linear interpolation between three readings in a standard pH 7 buffer solution. 


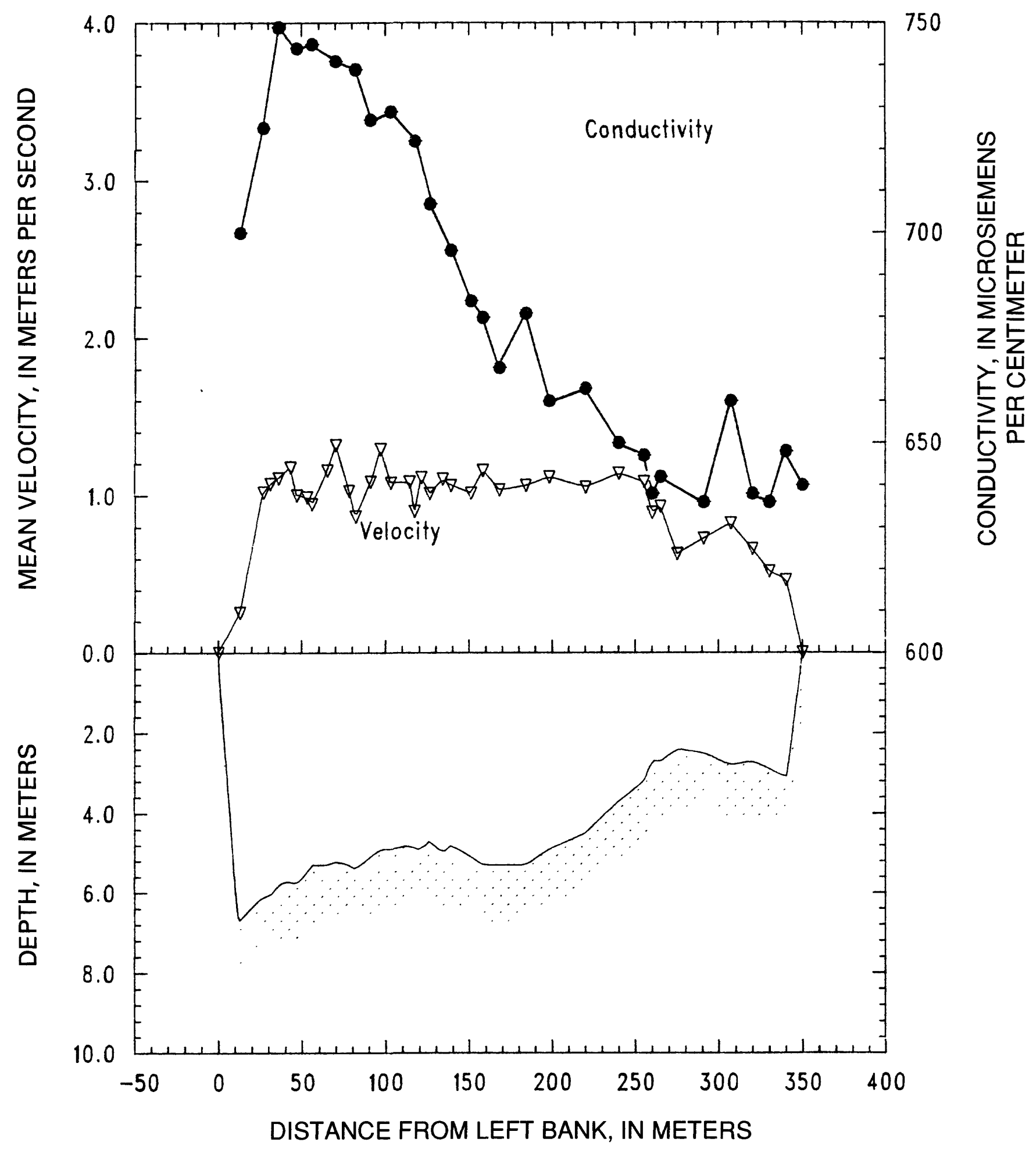

Figure 41. Missouri River at Hermann, Mo. on May 19, 1988. 
STATION: Mississippi River at St. Louis, Mo.

PARTY: Black, Moody, and Rees

STARTING GAGE HEIGHT: $6.75 \mathrm{ft}$

$5-20-88$

SUSP: Bag sampler and 200-1b weight

METER: PLASTIC CUP

METER No: P8308282 DATE RATED: 6-28-88

REMARKS: Transit rate 3 was $11 \mathrm{~cm} / \mathrm{sec}$ and the nozzle was $1 / 4$ inch. Total discharge was $3350 \mathrm{~m} / \mathrm{s}$. Verticals were occupied in the following order: $1-14,16,18-21,23-29,22,17,15$ and 5 .

\begin{tabular}{|c|c|c|c|c|c|c|c|c|c|}
\hline \multirow{3}{*}{$\begin{array}{c}\text { Verti- } \\
\text { cal }\end{array}$} & Dist. & Depth & Mean & Discharge & & & \multirow{2}{*}{$\begin{array}{c}\text { Temper- } \\
\text { ature }\end{array}$} & \multirow[t]{2}{*}{$\mathrm{pH}$} & \multirow{2}{*}{ Conductivity } \\
\hline & from & & velocity & & $\mathrm{Vi}$ & $\mathrm{Vp}$ & & & \\
\hline & $\begin{array}{l}\text { LEW } \\
(\mathrm{m})\end{array}$ & (m) & $(\mathrm{m} / \mathrm{s})$ & $\left(m^{3} / s\right)$ & $(\mathrm{mL})$ & (L) & $\left({ }^{\circ} \mathrm{C}\right)$ & & $\begin{array}{l}\text { (micro- } \\
\text { siemens/cm) }\end{array}$ \\
\hline
\end{tabular}

\begin{tabular}{|c|c|c|c|c|c|c|c|c|c|}
\hline LEW & 0 & 0.0 & 0.00 & 0 & -- & -- & -- & -- & -- \\
\hline $01 \mathrm{~A}$ & 16 & 10.7 & 0.68 & 102 & 5030 & 20 & 22.1 & 8.6 & 513 \\
\hline X01 & 28 & 10.2 & 0.91 & 88 & -- & -- & -- & -- & --- \\
\hline $02 B$ & 35 & 10.1 & 1.10 & 83 & 5750 & 20 & 22.1 & 8.6 & 502 \\
\hline $\mathrm{X} 02$ & 43 & 10.1 & 1.18 & 95 & -- & -- & -- & -- & --- \\
\hline $03 A$ & 51 & 10.0 & 1.18 & 82 & 5670 & 20 & 22.2 & 8.5 & 499 \\
\hline $\mathrm{X} 03$ & 57 & 10.0 & 1.16 & 87 & -- & -- & -- & -- & --- \\
\hline $04 \mathrm{~B}$ & 66 & 10.0 & 1.24 & 75 & 6030 & 20 & 22.5 & 8.5 & 504 \\
\hline $\mathrm{X} 04$ & 69 & 10.0 & 1.16 & 46 & -- & -- & -- & -- & --- \\
\hline $05 \mathrm{~A}$ & 74 & 10.0 & 1.16 & 98 & 6090 & 20 & 23.2 & 8.3 & 524 \\
\hline$x 05$ & 86 & 9.8 & 1.20 & 124 & -- & -- & -- & -- & -- \\
\hline $06 \mathrm{~B}$ & 95 & 9.7 & 1.19 & 87 & 5720 & 19 & 22.6 & 8.5 & 516 \\
\hline $\mathrm{X} 06$ & 101 & 9.5 & 1.13 & 70 & -- & -- & -- & -- & -- \\
\hline $07 A$ & 108 & 9.4 & 1.14 & 85 & 5340 & 17 & 22.6 & 8.5 & 519 \\
\hline$x 07$ & 117 & 9.2 & 1.15 & 89 & -- & -- & -- & -- & --- \\
\hline $08 \mathrm{~B}$ & 125 & 9.5 & 1.12 & 58 & 5460 & 16 & 22.6 & 8.5 & 526 \\
\hline $\mathrm{X} 08$ & 128 & 8.7 & 1.11 & 82 & -- & -- & -- & -- & --- \\
\hline $09 A$ & 142 & 8.4 & 1.17 & 147 & 4470 & 15 & 22.9 & 8.4 & 522 \\
\hline $10 \mathrm{~B}$ & 158 & 7.8 & 1.04 & 130 & 4460 & 14 & 22.9 & 8.4 & 533 \\
\hline $11 \mathrm{~A}$ & 174 & 7.4 & 1.11 & 140 & 3840 & 12 & 22.7 & 8.4 & 544 \\
\hline $12 \mathrm{~B}$ & 192 & 6.8 & 1.16 & 130 & 4110 & 11 & 23.0 & 8.3 & 567 \\
\hline $13 \mathrm{~A}$ & 207 & 6.6 & 0.90 & 92 & 3100 & 10 & 22.8 & 8.4 & 579 \\
\hline $14 \mathrm{~B}$ & 223 & 6.6 & 1.03 & 135 & 3490 & 10 & 23.2 & 8.2 & 585 \\
\hline $15 \mathrm{~A}$ & 247 & 6.0 & 1.15 & 124 & 2980 & 9 & 23.7 & 8.1 & 580 \\
\hline $16 \mathrm{~B}$ & 259 & 5.7 & 0.99 & 56 & 2720 & 9 & 22.8 & 8.3 & 584 \\
\hline $17 \mathrm{~A}$ & 267 & 5.7 & 1.01 & 72 & 3080 & 9 & 23.1 & 8.2 & 602 \\
\hline $18 \mathrm{~B}$ & 284 & 5.9 & 0.98 & 95 & 3250 & 8 & 23.1 & 8.3 & 619 \\
\hline $19 A$ & 300 & 5.6 & 1.10 & 89 & 2700 & 8 & 23.1 & 8.1 & 622 \\
\hline $20 \mathrm{~B}$ & 313 & 5.5 & 1.09 & 60 & 2570 & 9 & 22.8 & 8.1 & 612 \\
\hline $21 \mathrm{~A}$ & 320 & 5.5 & 0.93 & 74 & 2490 & 7 & 22.8 & 8.2 & 607 \\
\hline $22 B$ & 342 & 5.4 & 1.06 & 131 & 2710 & 8 & 23.3 & 8.1 & 631 \\
\hline $23 A$ & 366 & 5.3 & 0.63 & 51 & 1830 & 7 & 23.1 & 8.1 & 643 \\
\hline $24 \mathrm{~B}$ & 372 & 5.3 & 0.86 & 66 & 2310 & 7 & 23.0 & 8.1 & 641 \\
\hline $25 A$ & 395 & 5.5 & 0.76 & 92 & 2440 & 7 & 23.2 & 8.0 & 646 \\
\hline $26 B$ & 416 & 5.6 & 1.02 & 88 & 2290 & 7 & 23.3 & 8.0 & 651 \\
\hline $27 \mathrm{~A}$ & 426 & 5.6 & 0.91 & 59 & 2310 & 7 & 23.2 & 8.0 & 662 \\
\hline $28 \mathrm{~B}$ & 439 & 5.6 & 0.82 & 62 & 2260 & 8 & 23.2 & 7.9 & 671 \\
\hline $29 A$ & 453 & 5.8 & 0.74 & 103 & 2320 & 8 & 23.3 & 7.9 & 669 \\
\hline REW & 487 & 0.0 & 0.00 & 0 & -- & -- & -- & -- & --- \\
\hline
\end{tabular}




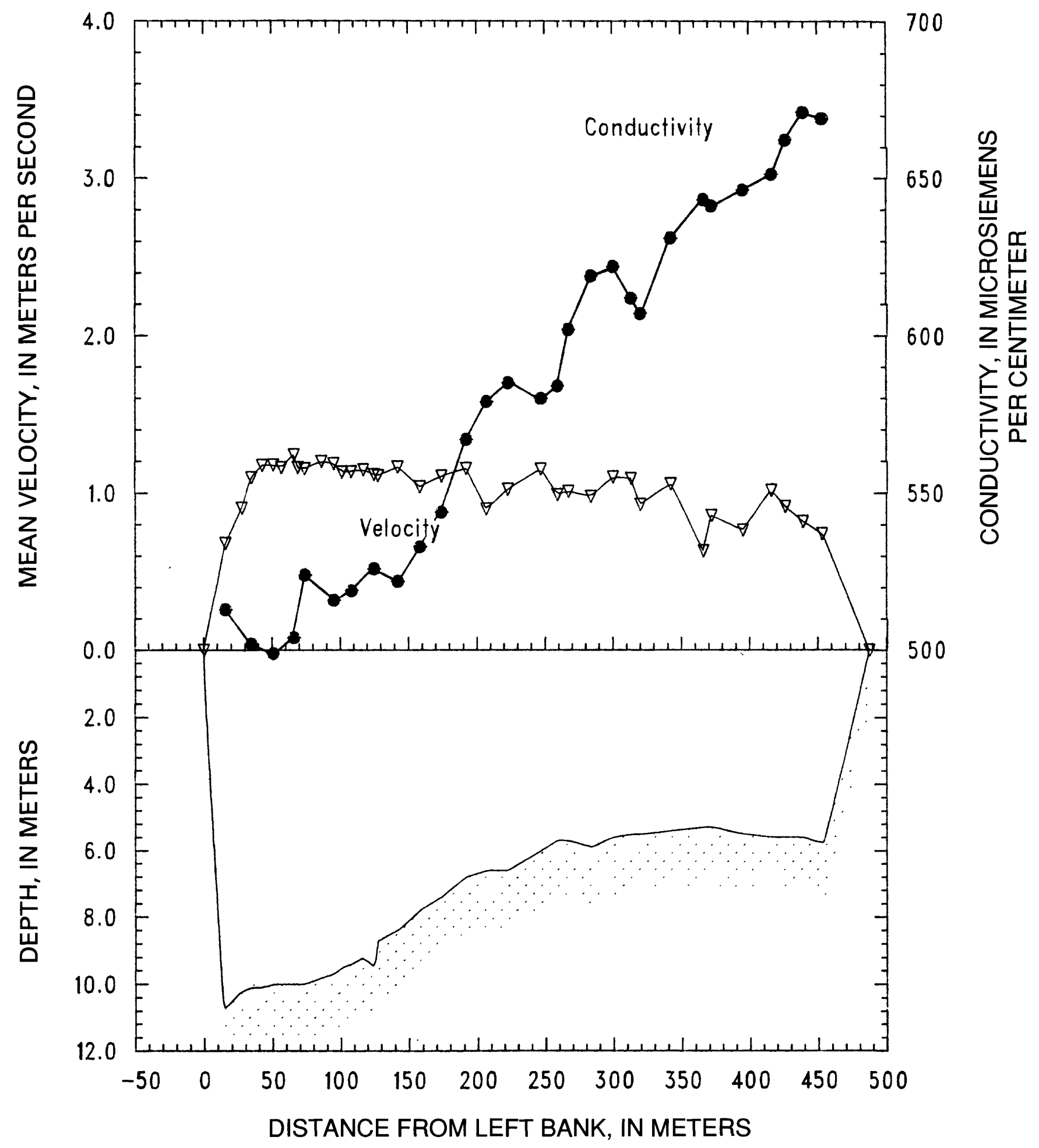

Figure 42. Mississippi River at St. Louis, Mo. on May 20, 1988. 
STATION: Mississippi River at Thebes, Ill.

PARTY: Simoneaux, Moody, and Stevens

STARTING GAGE HEIGHT: --

$5-22-88$

SUSP: Bag sampler and 200-1b weight

METER NO: P8308282 DATE RATED: 6-28-88

REMARKS: Transit rate 3 was $10 \mathrm{~cm} / \mathrm{sec}$ and the nozzle was $1 / 4$ inch. Total discharge was $3590 \mathrm{~m}^{3} / \mathrm{s}$. Verticals were occupied in the following order: 30-1. Cable broke between verticals $14 \mathrm{~A}$ and $13 \mathrm{~B}$ but nothing was lost!

\begin{tabular}{|c|c|c|c|c|c|c|c|c|c|}
\hline \multirow{3}{*}{$\begin{array}{c}\text { Verti- } \\
\text { cal }\end{array}$} & \multirow{3}{*}{$\begin{array}{l}\text { Dist. } \\
\text { from } \\
\text { LEW } \\
\text { (m) }\end{array}$} & \multirow{3}{*}{$\begin{array}{l}\text { Depth } \\
\text { (m) }\end{array}$} & \multirow{3}{*}{$\begin{array}{l}\text { Mean } \\
\text { velocity } \\
(\mathrm{m} / \mathrm{s})\end{array}$} & \multirow{3}{*}{$\begin{array}{l}\text { Discharge } \\
\left(\mathrm{m}^{3} / \mathrm{s}\right)\end{array}$} & \multicolumn{2}{|c|}{ Volume } & \multirow{3}{*}{$\begin{array}{l}\text { Temper- } \\
\text { ature } \\
\left({ }^{\circ} \mathrm{C}\right)\end{array}$} & \multirow[t]{3}{*}{$\mathrm{pH}$} & \multirow{3}{*}{$\begin{array}{l}\text { Conductivity } \\
\text { (micro- } \\
\text { siemens/cm) }\end{array}$} \\
\hline & & & & & $\mathrm{Vi}$ & $V p$ & & & \\
\hline & & & & & $(\mathrm{mL})$ & $(L)$ & & & \\
\hline LEW & 0 & 0.0 & 0.00 & 0 & - & - & -- & -- & -- \\
\hline $01 B$ & 22 & 4.0 & 0.62 & 36 & 1400 & 4 & 22.8 & 8.2 & 575 \\
\hline $02 \mathrm{~A}$ & 29 & 4.7 & 0.79 & 54 & 2010 & 12 & 22.9 & 8.2 & 578 \\
\hline $03 B$ & 51 & 6.4 & 0.76 & 108 & 2360 & 14 & 23.0 & 8.3 & 578 \\
\hline $04 \mathrm{~A}$ & 73 & 6.4 & 1.14 & 153 & 3330 & 13 & 23.0 & 8.3 & 586 \\
\hline $05 \mathrm{~B}$ & 93 & 6.7 & 1.18 & 103 & 3580 & 12 & 23.1 & 8.2 & 582 \\
\hline $06 \mathrm{~A}$ & 99 & 6.9 & 1.25 & 143 & 4230 & 15 & 23.1 & 8.2 & 581 \\
\hline $07 \mathrm{~B}$ & 126 & 6.6 & 1.37 & 191 & 4350 & 15 & 23.0 & 8.2 & 577 \\
\hline $08 \mathrm{~A}$ & 141 & 6.8 & 1.40 & 157 & 4900 & 14 & 23.1 & 8.2 & 593 \\
\hline $09 B$ & 159 & 6.9 & 1.19 & 90 & 4530 & 15 & 23.2 & 8.2 & 587 \\
\hline $10 \mathrm{~A}$ & 163 & 6.8 & 1.29 & 101 & 4040 & 15 & 23.2 & 8.2 & 588 \\
\hline $11 B$ & 182 & 6.6 & 1.29 & 161 & 4840 & 15 & 23.1 & 8.2 & 580 \\
\hline $12 \mathrm{~A}$ & 201 & 6.4 & 1.39 & 134 & 4170 & 14 & 23.1 & 8.2 & 594 \\
\hline $13 B$ & 212 & 6.7 & 1.23 & 165 & 4150 & 15 & 22.7 & 8.2 & 584 \\
\hline $14 \mathrm{~A}$ & 241 & 6.8 & 1.15 & 179 & 4260 & 14 & 22.8 & 8.2 & 580 \\
\hline $15 B$ & 258 & 6.9 & 1.15 & 151 & 4360 & 17 & 22.7 & 8.3 & 577 \\
\hline $16 \mathrm{~A}$ & 279 & 7.2 & 0.96 & 97 & 3830 & 15 & 22.7 & 8.3 & 580 \\
\hline $17 \mathrm{~B}$ & 286 & 7.2 & 1.07 & 54 & - & - & -- & -- & -- \\
\hline $17 \mathrm{~B}$ & 293 & 7.4 & 1.20 & 75 & 3700 & 15 & 22.7 & 8.3 & 581 \\
\hline$\times 10$ & 303 & 7.4 & 1.28 & 71 & -- & -- & -- & -- & -- \\
\hline $18 \mathrm{~A}$ & 308 & 7.3 & 1.15 & 51 & 5020 & 15 & 22.8 & 8.3 & 582 \\
\hline $\mathrm{x} 07$ & 315 & 7.6 & 1.13 & 77 & -- & -- & - & -- & -- \\
\hline $19 B$ & 326 & 7.8 & 1.12 & 92 & 4540 & 18 & 22.5 & 8.2 & 575 \\
\hline X06 & 336 & 7.7 & 1.17 & 76 & -- & -- & -- & - & -- \\
\hline $20 A$ & 343 & 7.8 & 1.16 & 86 & 4720 & 18 & 22.8 & 8.3 & 586 \\
\hline $\mathrm{X} 05$ & 355 & 8.3 & 1.48 & 105 & -- & -- & -- & -- & -- \\
\hline $21 B$ & 360 & 8.1 & 1.16 & 57 & 5690 & 19 & 23.0 & 8.2 & 578 \\
\hline $\mathrm{X} 04$ & 367 & 8.4 & 1.12 & 66 & -- & -- & -- & -- & -- \\
\hline $22 \mathrm{~A}$ & 374 & 8.4 & 1.06 & 71 & 4870 & 21 & 23.0 & 8.2 & 577 \\
\hline $\mathrm{x} 03$ & 383 & 7.8 & 1.12 & 74 & -- & -- & -- & -- & -- \\
\hline $23 B$ & 391 & 7.5 & 1.18 & 53 & 4770 & 18 & 23.0 & 8.2 & 588 \\
\hline $\mathrm{x} 02$ & 395 & 7.1 & 1.10 & 51 & - & - & - & - & -- \\
\hline
\end{tabular}



(cont inued)

\begin{tabular}{|c|c|c|c|c|c|c|c|c|c|}
\hline \multirow{3}{*}{$\begin{array}{c}\text { Verti- } \\
\text { cal }\end{array}$} & \multirow{3}{*}{$\begin{array}{l}\text { Dist. } \\
\text { from } \\
\text { LEW } \\
(\mathrm{m})\end{array}$} & \multirow{3}{*}{$\begin{array}{l}\text { Depth } \\
\text { (m) }\end{array}$} & \multirow{3}{*}{$\begin{array}{l}\text { Mean } \\
\text { velocity } \\
(\mathrm{m} / \mathrm{s})\end{array}$} & \multirow{3}{*}{$\begin{array}{l}\text { Discharge } \\
\left(\mathrm{m}^{3} / \mathrm{s}\right)\end{array}$} & \multicolumn{2}{|c|}{ Volume } & \multirow{3}{*}{$\begin{array}{c}\text { Temper- } \\
\text { ature } \\
\left({ }^{\circ} \mathrm{C}\right)\end{array}$} & \multirow[t]{3}{*}{$\mathrm{pH}$} & \multirow{3}{*}{$\begin{array}{l}\text { Conductivity } \\
\text { (micro- } \\
\text { siemens/cm) }\end{array}$} \\
\hline & & & & & $\mathrm{Vi}$ & $V p$ & & & \\
\hline & & & & & $(\mathrm{mL})$ & $(L)$ & & & \\
\hline X01 & 404 & 6.5 & 1.16 & 72 & -- & -- & -- & -- & --- \\
\hline $24 \mathrm{~A}$ & 414 & 6.3 & 1.27 & 76 & 4000 & 15 & 22.9 & 8.2 & 583 \\
\hline $25 B$ & 423 & 5.6 & 1.13 & 83 & 4530 & 12 & 22.9 & 8.2 & 592 \\
\hline $26 \mathrm{~A}$ & 440 & 4.8 & 1.19 & 103 & 2780 & 8 & 22.7 & 8.2 & 587 \\
\hline $27 B$ & 459 & 4.3 & 1.17 & 78 & 2780 & 7 & 22.8 & 8.3 & 591 \\
\hline $28 \mathrm{~A}$ & 471 & 3.9 & 1.27 & 34 & 2100 & 7 & 22.9 & 8.3 & 584 \\
\hline $29 B$ & 473 & 3.8 & 1.15 & 88 & 2120 & 6 & 23.0 & 8.3 & 582 \\
\hline $30 \mathrm{~A}$ & 511 & 4.3 & 0.15 & 17 & 250 & 6 & 22.8 & 8.3 & 590 \\
\hline REW & 525 & 0.0 & 0.00 & 0 & -- & -- & -- & -- & --- \\
\hline
\end{tabular}




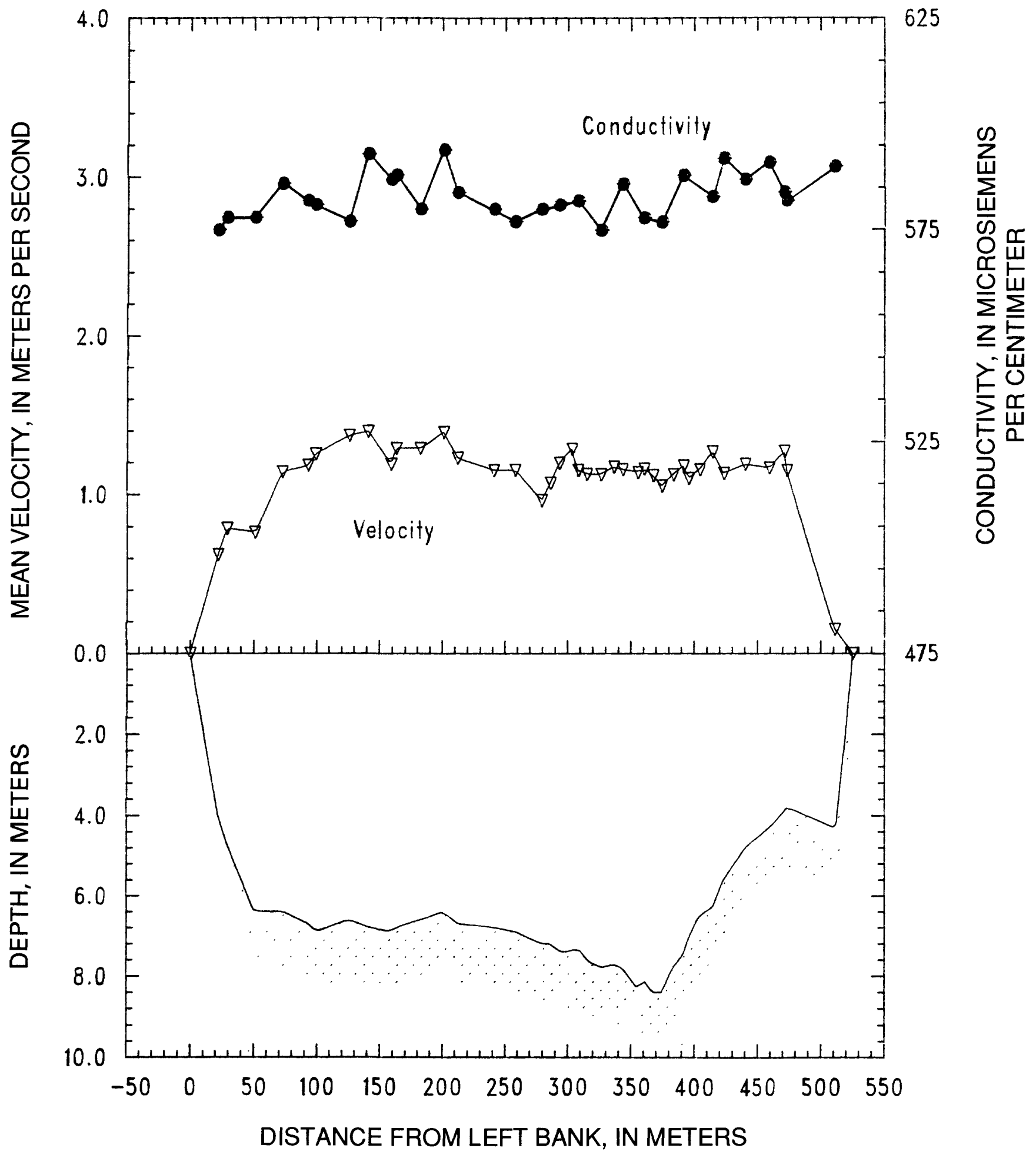

Figure 43. Mississippi River at Thebes, III. on May 22, 1988. 
STATION: Ohio River at Olmsted, Ill. PARTY: Simoneaux, Moody, and Stevens STARTING GAGE HEIGHT: $16.3 \mathrm{ft}$

$5-23-88$

METER : SOLID CUP

ENDING GAGE HEIGHT: $16.0 \mathrm{ft}$

SUSP: Bag sampler and 200-1b weight

METER No: P8308282 DATE RATED: 6-28-88

REMARKS: Transit rate was $6 \mathrm{~cm} / \mathrm{s}$ and the nozzle was $5 / 16$ inch. Anchored at each vertical in the following order: $1-30$. The total discharge was $3230 \mathrm{~m}^{3} / \mathrm{s}$.

\begin{tabular}{|c|c|c|c|c|c|c|c|c|c|}
\hline \multirow{3}{*}{$\begin{array}{c}\text { Verti- } \\
\text { cal }\end{array}$} & \multirow{3}{*}{$\begin{array}{l}\text { Dist. } \\
\text { Erom } \\
\text { LEW } \\
(\mathrm{m})\end{array}$} & \multirow{3}{*}{$\begin{array}{l}\text { Depth } \\
\text { (m) }\end{array}$} & \multirow{3}{*}{$\begin{array}{l}\text { Mean } \\
\text { velocity } \\
(\mathrm{m} / \mathrm{s})\end{array}$} & \multirow{3}{*}{$\begin{array}{l}\text { Discharge } \\
\left(\mathrm{m}^{3} / \mathrm{s}\right)\end{array}$} & \multicolumn{2}{|c|}{ Volume } & \multirow{3}{*}{$\begin{array}{c}\text { Temper- } \\
\text { ature } \\
\left({ }^{\circ} \mathrm{C}\right)\end{array}$} & \multirow[t]{3}{*}{$\mathrm{pH}$} & \multirow{3}{*}{$\begin{array}{l}\text { Conductivity } \\
\text { (micro- } \\
\text { siemens/cm) }\end{array}$} \\
\hline & & & & & $\mathrm{Vi}$ & $V p$ & & & \\
\hline & & & & & $(m L)$ & (L) & & & \\
\hline LEW & 0 & 0.0 & 0.00 & 0 & -- & -- & -- & -- & --- \\
\hline $30 \mathrm{~B}$ & 115 & 2.0 & 0.22 & 36 & 290 & 2 & 23.7 & 8.2 & 348 \\
\hline $29 A$ & 160 & 2.8 & 0.23 & 23 & 410 & 3 & 23.2 & 8.3 & 347 \\
\hline $28 \mathrm{~B}$ & 186 & 3.5 & 0.27 & 25 & 510 & 3 & 22.9 & 8.3 & 349 \\
\hline $27 A$ & 212 & 3.9 & 0.40 & 42 & 1070 & 4 & 23.2 & 8.3 & 352 \\
\hline $26 B$ & 240 & 4.5 & 0.45 & 52 & 1630 & 5 & 23.8 & 8.2 & 355 \\
\hline $25 A$ & 263 & 4.8 & 0.42 & 50 & 1710 & 6 & 23.0 & 8.2 & 354 \\
\hline $24 B$ & 289 & 5.1 & 0.44 & 64 & 2480 & 7 & 22.8 & 8.3 & 356 \\
\hline $23 A$ & 320 & 5.4 & 0.49 & 68 & 2470 & 8 & 22.9 & 8.3 & 352 \\
\hline $22 B$ & 340 & 5.3 & 0.53 & 70 & 2850 & 8 & 22.9 & 8.3 & 353 \\
\hline $21 A$ & 370 & 5.7 & 0.59 & 109 & 3320 & 9 & 23.0 & 8.3 & 353 \\
\hline $20 \mathrm{~B}$ & 405 & 5.3 & 0.55 & 85 & 4200 & 10 & 22.7 & 8.3 & 354 \\
\hline $19 A$ & 428 & 6.7 & 0.59 & 97 & 4060 & 12 & 22.4 & 8.4 & 362 \\
\hline $18 \mathrm{~B}$ & 454 & 7.1 & 0.68 & 126 & 5240 & 13 & 22.2 & 8.4 & 360 \\
\hline $17 \mathrm{~A}$ & 480 & 7.7 & 0.62 & 137 & 5430 & 14 & 21.8 & 8.4 & 364 \\
\hline $16 \mathrm{~B}$ & 511 & 7.7 & 0.63 & 119 & 5270 & 14 & 21.6 & 8.4 & 364 \\
\hline $15 \mathrm{~A}$ & 529 & 8.0 & 0.61 & 141 & 5800 & 15 & 21.6 & 8.4 & 364 \\
\hline $14 \mathrm{~B}$ & 569 & 7.8 & 0.72 & 151 & 6280 & 15 & 21.6 & 8.4 & 372 \\
\hline $13 \mathrm{~A}$ & 583 & 8.3 & 0.67 & 118 & 6330 & 13 & 21.9 & 8.4 & 371 \\
\hline $12 \mathrm{~B}$ & 612 & 7.2 & 0.68 & 138 & 5330 & 14 & 21.9 & 8.4 & 379 \\
\hline $11 \mathrm{~A}$ & 639 & 7.5 & 0.71 & 158 & 5590 & 14 & 22.0 & 8.4 & 385 \\
\hline $10 B$ & 671 & 8.0 & 0.71 & 167 & 6560 & 15 & 21.7 & 8.3 & 365 \\
\hline $09 A$ & 698 & 8.3 & 0.65 & 141 & 5830 & 17 & 21.7 & 8.4 & 381 \\
\hline $08 \mathrm{~B}$ & 723 & 8.7 & 0.69 & 164 & 6910 & 17 & 21.8 & 8.4 & 383 \\
\hline $07 \mathrm{~A}$ & 753 & 8.3 & 0.67 & 142 & 6390 & 16 & 21.6 & 8.4 & 382 \\
\hline $06 B$ & 774 & 8.3 & 0.64 & 107 & 5570 & 17 & 21.4 & 8.4 & 385 \\
\hline $05 A$ & 793 & 8.5 & 0.68 & 177 & 6100 & 17 & 21.7 & 8.3 & 388 \\
\hline $04 \mathrm{~B}$ & 835 & 8.3 & 0.73 & 188 & 6780 & 17 & 21.9 & 8.3 & 390 \\
\hline $03 A$ & 855 & 8.4 & 0.65 & 120 & 6740 & 17 & 21.7 & 8.2 & 389 \\
\hline $02 \mathrm{R}$ & 879 & 8.7 & 0.50 & 105 & -- & -- & -- & -- & -- \\
\hline $02 \mathrm{~B}$ & 903 & 8.8 & 0.35 & 46 & 4300 & 18 & 21.7 & 8.2 & 389 \\
\hline $01 \mathrm{~A}$ & 909 & 8.4 & 0.37 & 65 & 1820 & 12 & 22.2 & 8.2 & 389 \\
\hline REW & 945 & 0.0 & 0.00 & 0 & -- & -- & -- & -- & --- \\
\hline
\end{tabular}




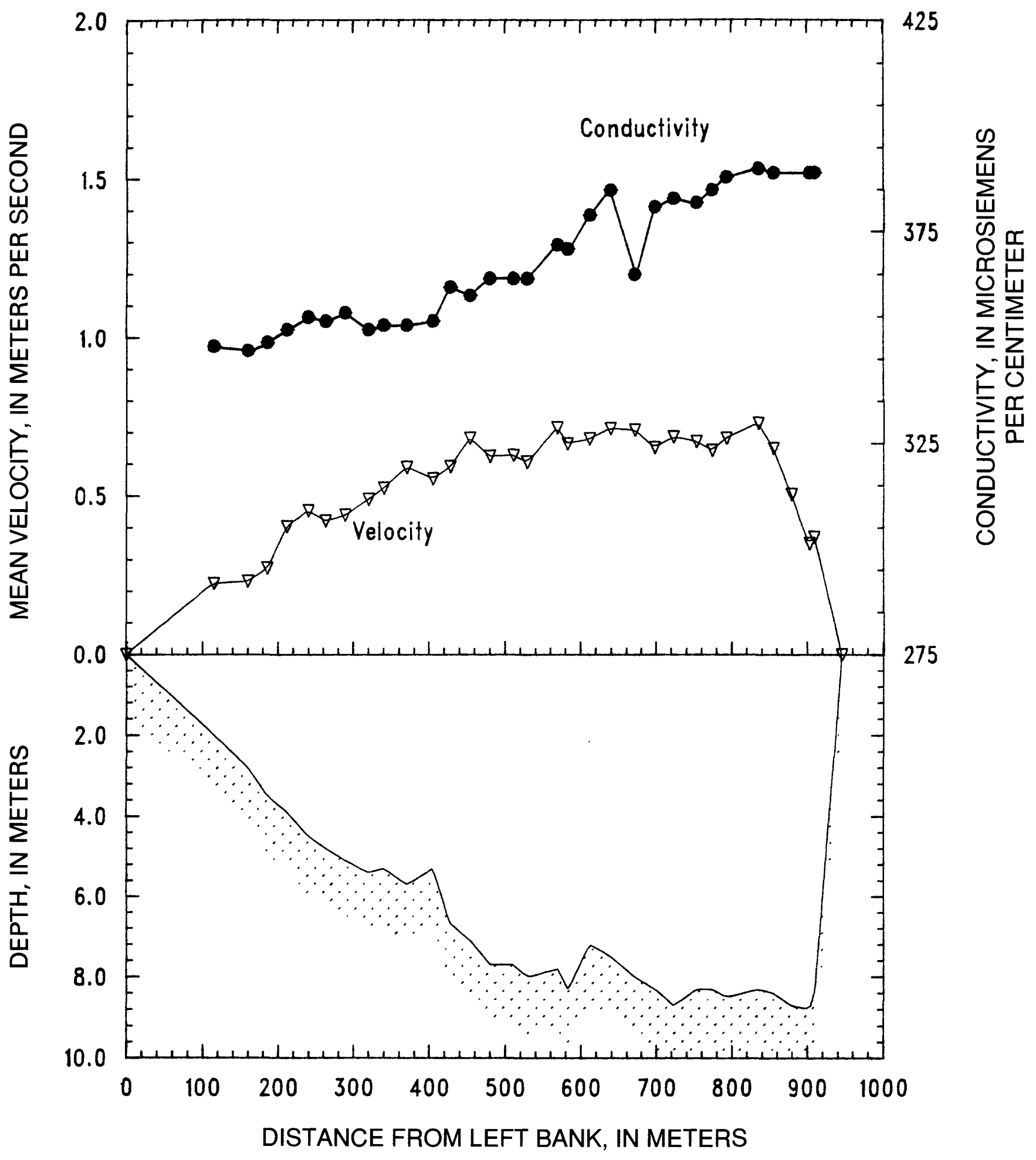

Figure 44. Ohio River at Olmsted, III. on May 23, 1988. 
STATION: Mississippi River below Hickman, Ky.

PARTY: Simoneaux, Moody, and Stevens

STARTING GAGE HEIGHT: $10.17 \mathrm{ft}$

METER: SOLID CUE
ENDING GAGE HEIGHT: $10.5 \mathrm{ft}$

$5-24-88$

SUSP: Bag sampler and 200-1b weight

METER NO: P8308282 DATE RATED: 6-28-88

REMARKS: Transit rate 3 was $11 \mathrm{~cm} / \mathrm{s}$ and the nozzle was $1 / 4$ inch. The total discharge was $6790 \mathrm{~m}^{3} / \mathrm{s}$.

\begin{tabular}{|c|c|c|c|c|c|c|c|c|c|}
\hline $\begin{array}{c}\text { Verti- } \\
\text { cal }\end{array}$ & $\begin{array}{l}\text { Dist. } \\
\text { from } \\
\text { LEW } \\
\text { (m) }\end{array}$ & Depth & $\begin{array}{l}\text { Mean } \\
\text { velocity } \\
(\mathrm{m} / \mathrm{s})\end{array}$ & $\begin{array}{l}\text { Discharge } \\
\left(\mathrm{m}^{3} / \mathrm{s}\right)\end{array}$ & $\begin{array}{l}\mathrm{Vi}^{\mathrm{Vo}} \\
(\mathrm{mL})\end{array}$ & $\begin{array}{l}\text { me } \\
\text { Vp } \\
(L)\end{array}$ & $\begin{array}{c}\text { Temper- } \\
\text { ature } \\
\left({ }^{\circ} \mathrm{C}\right)\end{array}$ & $\mathrm{pH}$ & $\begin{array}{l}\text { Conductivity } \\
\text { (micro- } \\
\text { siemens } / \mathrm{cm} \text { ) }\end{array}$ \\
\hline LEW & 0 & 0.0 & 0.00 & 0 & -- & -- & -- & -- & --- \\
\hline $01 R$ & 35 & 5.9 & 1.04 & 153 & -- & -- & -- & -- & --- \\
\hline $01 \mathrm{~A}$ & 50 & 6.4 & 0.94 & 138 & 2140 & 14 & 22.1 & 8.1 & 439 \\
\hline $02 B$ & 81 & 7.2 & 1.21 & 239 & 3750 & 18 & 22.3 & 8.1 & 440 \\
\hline $03 A$ & 105 & 7.2 & 1.24 & 218 & 3920 & 18 & 22.1 & 8.1 & 440 \\
\hline $04 \mathrm{~B}$ & 130 & 5.8 & 1.19 & 206 & 4140 & 17 & 22.1 & 8.1 & 438 \\
\hline $\mathrm{X} 02$ & 156 & 6.5 & 1.36 & 159 & -- & -- & -- & -- & --- \\
\hline $05 A$ & 166 & 6.4 & 1.38 & 221 & 3780 & 15 & 21.9 & 8.1 & 439 \\
\hline $06 B$ & 206 & 6.3 & 1.30 & 253 & 3750 & 15 & 22.0 & 8.1 & 440 \\
\hline $07 A$ & 228 & 6.3 & 1.15 & 192 & 3710 & 14 & 21.9 & 8.1 & 440 \\
\hline $08 \mathrm{~B}$ & 259 & 6.3 & 1.28 & 241 & 3660 & 14 & 22.0 & 8.1 & 451 \\
\hline $09 A$ & 288 & 6.0 & 1.16 & - 223 & 3360 & 14 & 22.1 & 8.1 & 448 \\
\hline $10 \mathrm{~B}$ & 323 & 5.4 & 1.11 & 225 & 2870 & 14 & 22.2 & 8.1 & 460 \\
\hline $11 \mathrm{~A}$ & 363 & 5.9 & 0.97 & 180 & 2720 & 14 & 22.0 & 8.1 & 452 \\
\hline $12 \mathrm{~B}$ & 386 & 6.2 & 1.13 & 196 & 3360 & 13 & 21.9 & 8.1 & 455 \\
\hline $13 \mathrm{~A}$ & 419 & 6.0 & 0.89 & 101 & -- & -- & -- & -- & --- \\
\hline $13 R$ & 424 & 6.0 & 1.02 & 104 & 2500 & 13 & 22.0 & 8.1 & 459 \\
\hline $14 \mathrm{~B}$ & 453 & 6.0 & 1.10 & 194 & 2700 & 13 & 21.9 & 8.1 & 468 \\
\hline $15 \mathrm{~A}$ & 483 & 6.1 & 1.08 & 207 & 2930 & 14 & 22.1 & 8.1 & 472 \\
\hline $16 \mathrm{~B}$ & 516 & 6.5 & 1.03 & 211 & 2950 & 15 & 22.3 & 8.1 & 481 \\
\hline $17 \mathrm{~A}$ & 546 & 6.9 & 0.96 & 216 & 3140 & 16 & 22.3 & 8.1 & 482 \\
\hline $18 \mathrm{~B}$ & 581 & 7.6 & 1.03 & 264 & 3810 & 18 & 22.3 & 8.1 & 489 \\
\hline $19 \mathrm{~A}$ & 613 & 7.7 & 0.97 & 217 & 3390 & 18 & 22.4 & 8.1 & 489 \\
\hline $20 B$ & 639 & 7.9 & 0.98 & 252 & 3410 & 19 & 22.4 & 8.1 & 500 \\
\hline $21 \mathrm{~A}$ & 678 & 8.1 & 0.97 & 260 & 3940 & 21 & 22.4 & 8.1 & 504 \\
\hline $22 B$ & 705 & 8.3 & 0.92 & 219 & 3560 & 23 & 22.5 & 8.1 & 510 \\
\hline $23 A$ & 735 & 8.3 & 1.17 & 300 & 3940 & 24 & 22.5 & 8.1 & 518 \\
\hline $24 B$ & 767 & 8.4 & 1.00 & 282 & 3740 & 23 & 22.5 & 8.1 & 523 \\
\hline $25 \mathrm{~A}$ & 802 & 8.4 & 0.97 & 266 & 3810 & 23 & 22.6 & 8.1 & 526 \\
\hline $26 B$ & 832 & 7.8 & 0.98 & 182 & 3520 & 22 & 22.6 & 8.1 & 531 \\
\hline $\mathrm{X} 01$ & 850 & 8.0 & 0.92 & 137 & -- & -- & -- & -- & --- \\
\hline
\end{tabular}


STATION: Mississippi River below Hickman, Ky.

$5-24-88$ (cont inued)

\begin{tabular}{|c|c|c|c|c|c|c|c|c|c|}
\hline \multirow{3}{*}{$\begin{array}{c}\text { Verti- } \\
\text { cal }\end{array}$} & \multirow{3}{*}{$\begin{array}{l}\text { Dist. } \\
\text { from } \\
\text { LEW } \\
(m)\end{array}$} & \multirow{3}{*}{$\begin{array}{l}\text { Depth } \\
\text { (m) }\end{array}$} & \multirow{3}{*}{$\begin{array}{l}\text { Mean } \\
\text { velocity } \\
(\mathrm{m} / \mathrm{s})\end{array}$} & \multirow{3}{*}{$\begin{array}{c}\text { Discharge } \\
\left(\mathrm{m}^{3} / \mathrm{s}\right)\end{array}$} & \multicolumn{2}{|c|}{ Volume } & \multirow{3}{*}{$\begin{array}{l}\text { Temper- } \\
\text { ature } \\
\left({ }^{\mathrm{O}} \mathrm{C}\right)\end{array}$} & \multirow{3}{*}{$\mathrm{pH}$} & \multirow{3}{*}{$\begin{array}{l}\text { Conductivity } \\
\text { (micro- } \\
\text { siemens } / \mathrm{cm} \text { ) }\end{array}$} \\
\hline & & & & & $V i$ & $V p$ & & & \\
\hline & & & & & $(\mathrm{mL})$ & (L) & & & \\
\hline $27 \mathrm{~A}$ & 869 & 8.3 & 0.85 & 149 & 3550 & 24 & 22.7 & 8.1 & 535 \\
\hline $28 B$ & 892 & 7.9 & 0.78 & 105 & 3140 & 22 & 22.7 & 8.1 & 535 \\
\hline $28 \mathrm{R}$ & 903 & 5.7 & 0.87 & 84 & -- & -- & -- & -- & --- \\
\hline $29 A$ & 926 & 5.5 & 0.83 & 146 & 2040 & 11 & 22.6 & 8.1 & 535 \\
\hline $30 \mathrm{~B}$ & 967 & 2.4 & 0.61 & 47 & 500 & 2 & 22.5 & 8.2 & 527 \\
\hline REW & 991 & 0.0 & 0.00 & 0 & 0 & 0 & -- & -- & 0 \\
\hline
\end{tabular}




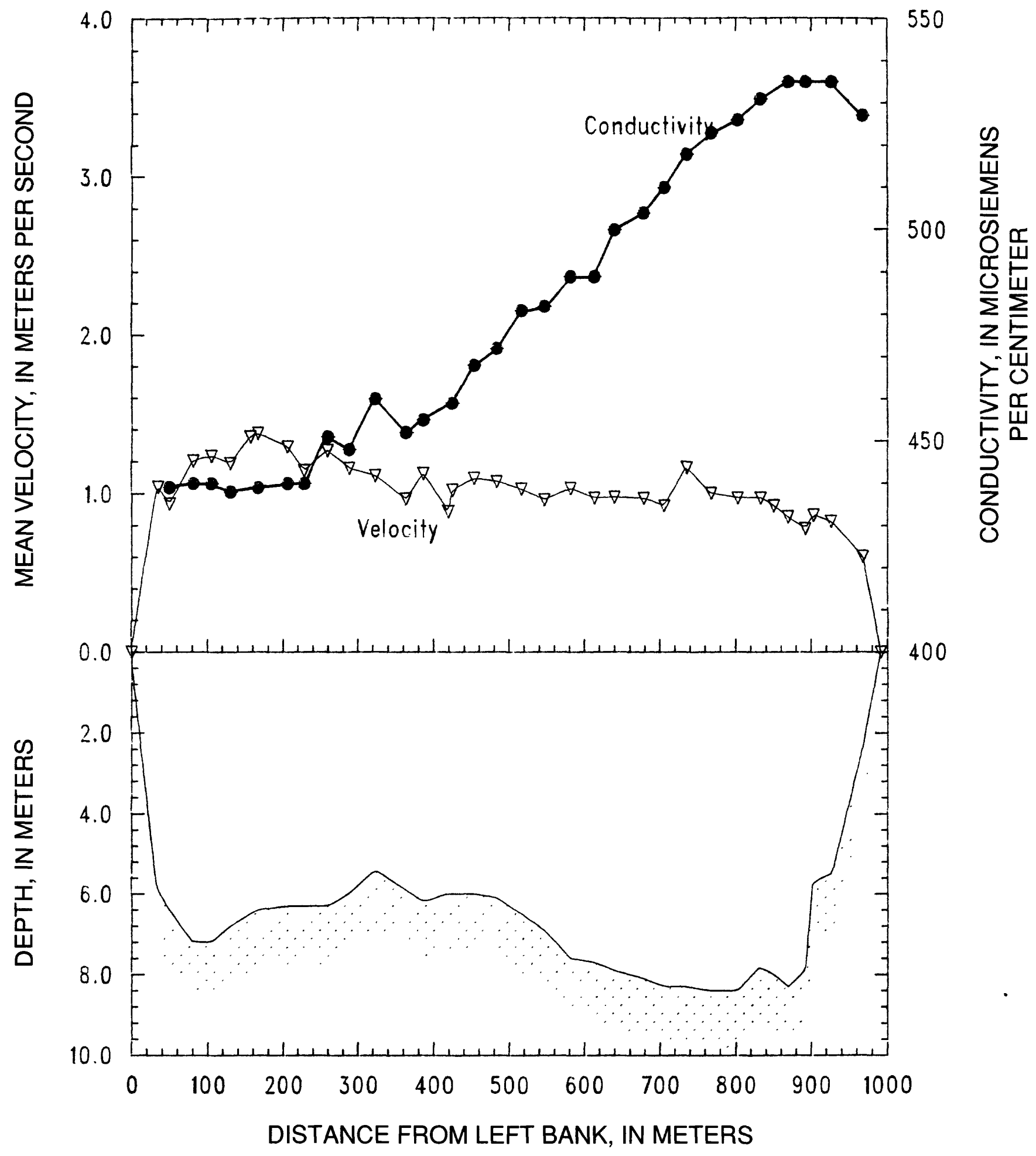

Figure 45. Mississippi River below Hickman, Ky. on May 24, 1988. 
STATION: Mississippi River at Fulton, Tenn.

PARTY: Simoneaux, Moody, and Stevens

STARTING GAGE HEIGHT:

$5-26-88$

SUSP: Bag sampler and 200-1b weight

METER: SOLID CUP

METER No: P8308282 DATE RATED: 6-28-88

REMARKS: Transit rate, was $7 \mathrm{~cm} / \mathrm{s}$ and the nozzle was $3 / 16$ inch. The total discharge was $7170 \mathrm{~m}^{3} / \mathrm{s}$.

$$
\text { discharge was } 7170 \text { m } / \mathrm{s} \text {. }
$$

\begin{tabular}{|c|c|c|c|c|c|c|c|c|c|}
\hline \multirow{3}{*}{$\begin{array}{c}\text { Verti- } \\
\text { cal }\end{array}$} & \multirow{3}{*}{$\begin{array}{l}\text { Dist. } \\
\text { from } \\
\text { LEW } \\
(m)\end{array}$} & \multirow{3}{*}{$\begin{array}{l}\text { Depth } \\
\text { (m) }\end{array}$} & \multirow{3}{*}{$\begin{array}{l}\text { Mean } \\
\text { velocity } \\
(\mathrm{m} / \mathrm{s})\end{array}$} & \multirow{3}{*}{$\begin{array}{l}\text { Discharge } \\
\left(\mathrm{m}^{3} / \mathrm{s}\right)\end{array}$} & \multicolumn{2}{|c|}{ Volume } & \multirow{3}{*}{$\begin{array}{c}\text { Temper- } \\
\text { ature } \\
\left({ }^{\mathrm{O}} \mathrm{C}\right)\end{array}$} & \multirow[t]{3}{*}{$\mathrm{pH}$} & \multirow{3}{*}{$\begin{array}{l}\text { Conductivity } \\
\text { (micro- } \\
\text { siemens/cm) }\end{array}$} \\
\hline & & & & & $\mathrm{Vi}$ & $V p$ & & & \\
\hline & & & & & $(\mathrm{mL})$ & $(L)$ & & & \\
\hline LEW & 0 & 0.0 & 0.00 & 0 & -- & -- & - & -- & -- \\
\hline $01 \mathrm{~A}$ & 64 & 3.6 & 0.73 & 106 & 770 & 2 & 21.2 & 8.1 & $477^{\circ}$ \\
\hline $02 \mathrm{~B}$ & 81 & 4.7 & 0.90 & 86 & 1490 & 3 & 21.1 & 8.1 & 473 \\
\hline $03 A$ & 105 & 5.8 & 0.77 & 119 & 1970 & 4 & 20.9 & 8.1 & 478 \\
\hline $04 \mathrm{~B}$ & 134 & 6.8 & 0.93 & 183 & 2530 & 6 & 20.6 & 8.1 & 482 \\
\hline $05 \mathrm{~A}$ & 163 & 7.3 & 1.05 & 200 & 3490 & 8 & 20.8 & 8.1 & 480 \\
\hline $06 \mathrm{~B}$ & 186 & 7.8 & 1.05 & 168 & 3470 & 14 & 20.8 & 8.1 & 480 \\
\hline $07 \mathrm{~A}$ & 204 & 8.2 & 1.07 & 223 & 3960 & 17 & 20.9 & 8.1 & 480 \\
\hline $08 \mathrm{~B}$ & 237 & 8.8 & 1.16 & 250 & 4970 & 19 & 21.5 & 8.0 & 465 \\
\hline $09 R$ & 253 & 9.9 & 1.07 & 144 & 5580 & 20 & 21.5 & 8.0 & 465 \\
\hline $09 A$ & 264 & 10.0 & 1.10 & 198 & -- & - & -- & -- & -- \\
\hline $10 \mathrm{~B}$ & 289 & 10.5 & 1.28 & 302 & 5990 & 23 & 21.6 & 8.0 & 449 \\
\hline $11 \mathrm{~A}$ & 309 & 10.4 & 1.29 & 248 & 6390 & 23 & 21.6 & 8.0 & 447 \\
\hline $\mathrm{x} 01$ & 326 & 10.8 & 1.25 & 175 & -- & -- & -- & -- & -- \\
\hline $12 \mathrm{~B}$ & 335 & 10.7 & 1.18 & 178 & 6090 & 23 & 21.6 & 8.0 & 478 \\
\hline $13 A$ & 354 & 11.5 & 1.26 & 225 & 6020 & 26 & 21.7 & 8.1 & 460 \\
\hline $\mathrm{X} 02$ & 366 & 11.7 & 1.31 & 282 & -- & -- & -- & -- & --- \\
\hline $14 \mathrm{~B}$ & 391 & 11.8 & 1.10 & 304 & 5840 & 29 & 21.7 & 8.1 & 471 \\
\hline $15 \mathrm{~A}$ & 413 & 12.6 & 1.13 & 242 & 6270 & 28 & 21.7 & 8.1 & 474 \\
\hline $16 \mathrm{R}$ & 425 & 12.3 & 1.12 & 124 & 5430 & 24 & 21.7 & 8.0 & 464 \\
\hline $16 \mathrm{~B}$ & 431 & 12.7 & 1.12 & 200 & -- & -- & -- & -- & -- \\
\hline $17 \mathrm{~A}$ & 453 & 13.5 & 1.16 & 329 & 5520 & 25 & 21.7 & 8.1 & 477 \\
\hline $18 \mathrm{~B}$ & 473 & 13.0 & 1.16 & 286 & 6460 & 27 & 21.7 & 8.1 & 478 \\
\hline $19 \mathrm{~A}$ & 491 & 11.4 & 1.16 & 338 & 5120 & 27 & 21.8 & 8.1 & 473 \\
\hline $20 \mathrm{~B}$ & 524 & 11.0 & 1.25 & 419 & 6020 & 23 & 21.8 & 8.1 & 463 \\
\hline $21 \mathrm{~A}$ & 552 & 10.5 & 1.06 & 273 & 5290 & 23 & 22.0 & 8.1 & 469 \\
\hline $22 B$ & 573 & 10.3 & 1.18 & 237 & 5000 & 20 & 22.2 & 8.1 & 452 \\
\hline $23 A$ & 591 & 10.0 & 1.09 & 246 & 4730 & 18 & 22.4 & 8.1 & 467 \\
\hline $24 \mathrm{~B}$ & 618 & 9.7 & 0.95 & 230 & 4180 & 19 & 22.0 & 8.1 & 476 \\
\hline $25 A$ & 641 & 9.3 & 0.99 & 276 & 4570 & 16 & 22.1 & 8.1 & 475 \\
\hline $26 B$ & 678 & 8.7 & 0.96 & 209 & 3560 & 12 & 22.2 & 8.1 & 477 \\
\hline $27 \mathrm{~A}$ & 691 & 8.3 & 0.79 & 137 & 2730 & 10 & 22.1 & 8.1 & 484 \\
\hline $28 B$ & 720 & 7.0 & 0.67 & 130 & 1930 & 7 & 22.2 & 8.1 & 480 \\
\hline $29 A$ & 746 & 5.5 & 0.56 & 69 & 920 & 4 & 22.2 & 8.1 & 481 \\
\hline $30 \mathrm{~B}$ & 765 & 2.8 & 0.45 & 37 & 510 & 3 & 22.2 & 8.1 & 480 \\
\hline REW & 805 & 0.0 & 0.00 & 0 & -- & -- & -- & -- & -- \\
\hline
\end{tabular}




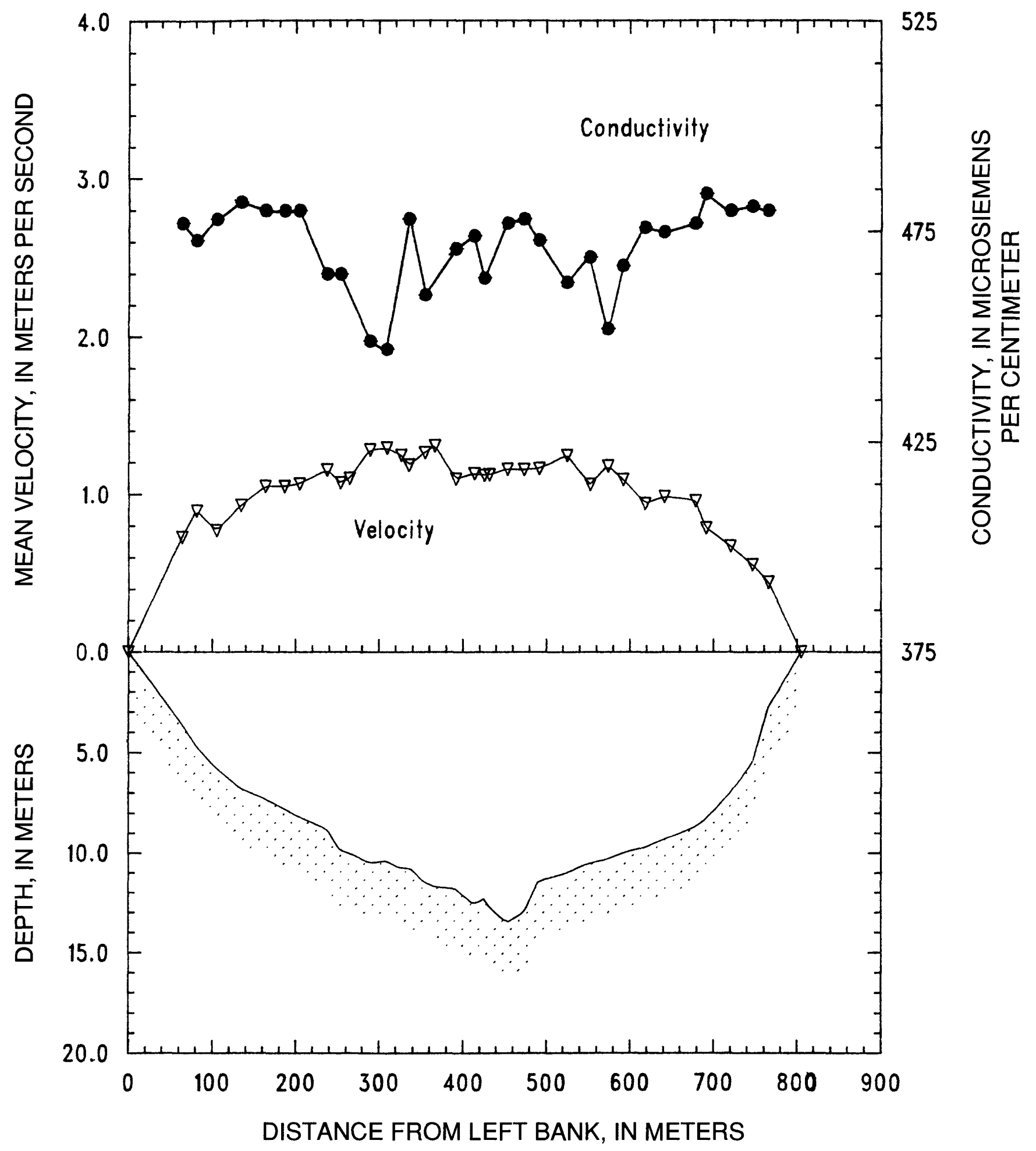

Figure 46. Mississippi River at Fulton, Tenn. on May 26, 1988. 
STATION: Mississippi River at Helena, Ark.

PARTY: Black, Moody, and Stevens

$5-28-88$

STARTING GAGE HEIGHT: $7.05 \mathrm{ft}$

METER: SOLID CUP

SUSP: Bag sampler and 200-1b weight

METER No: P8308282 DATE RATED: 4-22-88

REMARKS: Transit rate 3 was $14 \mathrm{~cm} / \mathrm{sec}$ and the nozzle was $1 / 4$ inch. The total discharge was $7050 \mathrm{~m}^{3} / \mathrm{s}$.

\begin{tabular}{|c|c|c|c|c|c|c|c|c|c|}
\hline Verti- & Dist. & Depth & Mean & Discharge & & & Temper- & $\mathrm{pH}$ & Conductivity \\
\hline cal & from & & velocity & & $\mathrm{Vi}$ & $V p$ & ature & & \\
\hline & $\begin{array}{l}\text { LEW } \\
(\mathrm{m})\end{array}$ & (m) & $(\mathrm{m} / \mathrm{s})$ & $\left(m^{3} / s\right)$ & $(m L)$ & $(L)$ & $\left({ }^{\circ} \mathrm{C}\right)$ & & $\begin{array}{l}\text { (micro- } \\
\text { siemens } / \mathrm{cm} \text { ) }\end{array}$ \\
\hline LEW & 0 & 0.0 & 0.00 & 0 & -- & -- & -- & -- & -- \\
\hline $01 \mathrm{~A}$ & 27 & 8.0 & 1.26 & 236 & 4150 & 17 & 22.2 & 8.1 & 476 \\
\hline $\mathrm{x} 01$ & 47 & 10.0 & 1.52 & 252 & -- & -- & -- & -- & -- \\
\hline 02B & 60 & 9.8 & 1.23 & 150 & 5580 & 24 & 22.3 & 8.1 & 464 \\
\hline $\mathrm{x} 02$ & 72 & 10.1 & 1.60 & 153 & - & -- & -- & -- & -- \\
\hline $03 \mathrm{~A}$ & 79 & 10.0 & 1.66 & 190 & 6570 & 26 & 22.3 & 8.1 & 477 \\
\hline $\mathrm{x} 03$ & 95 & 10.2 & 1.55 & 173 & -- & -- & -- & -- & -- \\
\hline $04 \mathrm{~B}$ & 101 & 10.0 & 1.62 & 194 & 6410 & 29 & 22.2 & 8.1 & 477 \\
\hline $\mathrm{x} 04$ & 119 & 10.3 & 1.63 & 234 & -- & -- & -- & -- & --- \\
\hline $05 \mathrm{~A}$ & 129 & 10.2 & 1.53 & 212 & 5860 & 27 & 22.3 & 8.1 & 479 \\
\hline $\mathrm{X} 05$ & 146 & 10.0 & 1.55 & 163 & -- & -- & -- & -- & --- \\
\hline $06 \mathrm{R}$ & 150 & 10.1 & 1.69 & 111 & 5900 & 25 & 22.3 & 8.1 & 478 \\
\hline $06 \mathrm{~B}$ & 159 & 10.0 & 1.72 & 180 & -- & -- & -- & -- & --- \\
\hline $\mathrm{x} 06$ & 171 & 9.7 & 1.40 & 143 & 5390 & 24 & 22.4 & 8.1 & 479 \\
\hline $07 \mathrm{~A}$ & 180 & 9.6 & 1.40 & $18=$ & -- & -- & -- & -- & --- \\
\hline $08 \mathrm{~B}$ & 198 & 9.5 & 1.46 & 257 & 5380 & 24 & 22.5 & 8.1 & 476 \\
\hline$x 07$ & 217 & 9.4 & 1.58 & 216 & -- & - & -- & -- & -- \\
\hline $09 \mathrm{~A}$ & 227 & 9.5 & 1.39 & 172 & 5440 & 22 & 22.4 & 8.1 & 478 \\
\hline $\mathrm{x} 08$ & 243 & 9.5 & 1.36 & 129 & -- & -- & -- & -- & -- \\
\hline $10 \mathrm{~B}$ & 247 & 9.4 & 1.47 & 166 & 5250 & 21 & 22.6 & 8.1 & 479 \\
\hline X09 & 267 & 9.3 & 1.33 & 155 & -- & -- & -- & -- & -- \\
\hline $11 A$ & 272 & 9.3 & 1.51 & 204 & 5020 & 19 & 22.4 & 8.1 & 479 \\
\hline $12 \mathrm{R}$ & 296 & 9.0 & 1.46 & 191 & 5470 & 20 & 22.6 & 8.1 & 477 \\
\hline $12 \mathrm{~B}$ & 301 & 8.9 & 1.53 & 177 & -- & -- & -- & -- & --- \\
\hline $13 \mathrm{~A}$ & 322 & 8.5 & 1.35 & 247 & 4640 & 20 & 22.7 & 8.1 & 479 \\
\hline $14 \mathrm{~B}$ & 344 & 8.5 & 1.21 & 262 & 3870 & 18 & 22.8 & 8.1 & 477 \\
\hline $15 \mathrm{~A}$ & 373 & 8.1 & 1.31 & 265 & 4440 & 18 & 23.0 & 8.1 & 475 \\
\hline $16 \mathrm{~B}$ & 394 & 7.7 & 1.17 & 203 & 3550 & 18 & 23.2 & 8.1 & 480 \\
\hline $17 \mathrm{~A}$ & 418 & 7.3 & 1.10 & 168 & 3370 & 16 & 23.1 & 8.1 & 479 \\
\hline $18 \mathrm{R}$ & 436 & 7.3 & 1.23 & 157 & 3230 & 16 & 23.2 & 8.1 & 482 \\
\hline $18 \mathrm{~B}$ & 453 & 7.1 & 1.10 & 101 & -- & -- & -- & -- & -- \\
\hline $19 \mathrm{~A}$ & 462 & 6.8 & 1.06 & 43 & -- & -- & -- & -- & --- \\
\hline $19 \mathrm{R}$ & 465 & 6.8 & 1.20 & 110 & 3020 & 17 & 23.1 & 8.1 & 482 \\
\hline $20 \mathrm{~B}$ & 489 & 6.8 & 0.96 & 157 & 2600 & 16 & 23.1 & 8.0 & 481 \\
\hline
\end{tabular}




\begin{tabular}{|c|c|c|c|c|c|c|c|c|c|}
\hline $\begin{array}{c}\text { Verti- } \\
\text { cal }\end{array}$ & $\begin{array}{l}\text { Dist. } \\
\text { from } \\
\text { LEW } \\
(m)\end{array}$ & Depth & $\begin{array}{l}\text { Mean } \\
\text { velocity } \\
(\mathrm{m} / \mathrm{s})\end{array}$ & $\begin{array}{l}\text { Discharge } \\
\left(\mathrm{m}^{3} / \mathrm{s}\right)\end{array}$ & $\begin{array}{l}\mathrm{Vi} \\
(\mathrm{mL})\end{array}$ & $\begin{array}{l}\text { me } \\
\text { Vp } \\
\text { (L) }\end{array}$ & $\begin{array}{c}\text { Temper- } \\
\text { ature } \\
\left({ }^{\circ} \mathrm{C}\right)\end{array}$ & $\mathrm{pH}$ & $\begin{array}{l}\text { Conductivity } \\
\text { (micro- } \\
\text { siemens/cm) }\end{array}$ \\
\hline $21 \mathrm{~A}$ & 513 & 6.8 & 0.94 & 128 & 2220 & 15 & 23.1 & 8.1 & 483 \\
\hline $22 \mathrm{~B}$ & 529 & 6.8 & 1.06 & 163 & 2240 & 13 & 23.1 & 8.1 & 480 \\
\hline $23 \mathrm{~A}$ & 558 & 7.1 & 0.91 & 184 & 2170 & 12 & 23.2 & 8.1 & 480 \\
\hline $24 \mathrm{~B}$ & 586 & 6.7 & 0.87 & 145 & 2170 & 11 & 23.3 & 8.0 & 481 \\
\hline $25 A$ & 608 & 5.9 & 0.96 & 134 & 2210 & 8 & 23.3 & 8.1 & 482 \\
\hline $26 \mathrm{~B}$ & 633 & 5.5 & 0.70 & 93 & 1330 & 6 & 23.1 & 8.1 & 481 \\
\hline $27 A$ & 656 & 5.1 & 0.74 & 85 & 1350 & 6 & 23.2 & 8.1 & 481 \\
\hline $28 B$ & 678 & 4.4 & 0.79 & 77 & 1090 & 4 & 23.3 & 8.1 & 478 \\
\hline $29 A$ & 700 & 2.7 & 0.78 & 36 & 610 & 4 & 23.4 & 8.1 & 479 \\
\hline $30 \mathrm{~B}$ & 712 & 2.4 & 0.84 & 55 & 380 & 3 & 23.8 & 8.1 & 481 \\
\hline REW & 754 & 0.0 & 0.00 & 0 & -- & -- & -- & -- & --- \\
\hline
\end{tabular}




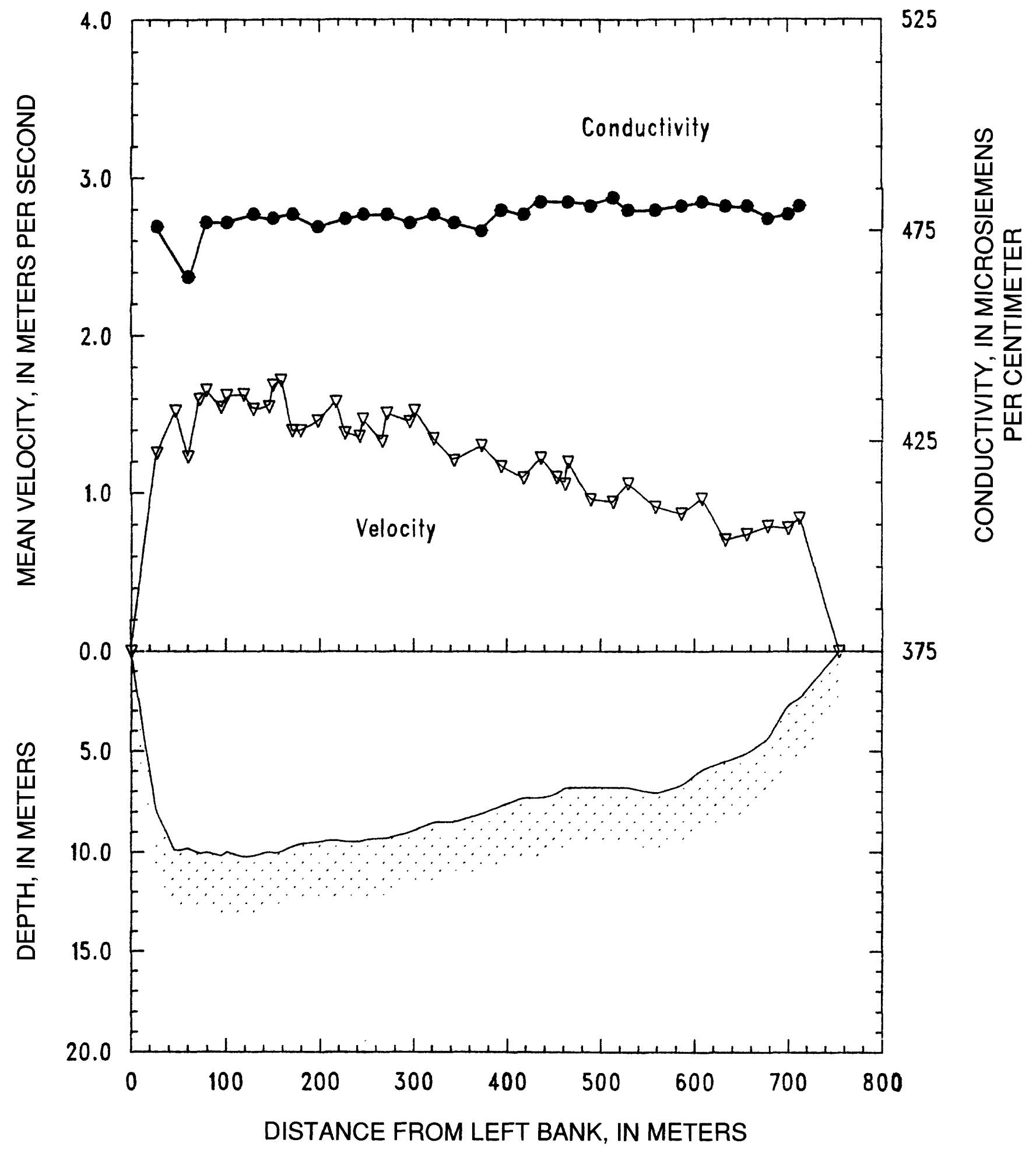

Figure 47. Mississippi River at Helena, Ark. on May 28, 1988. 
STATION: White River at Mile 11.5, Ark. PARTY: Black, Moody and Stevens

STARTING GAGE HEIGHT: $21.9 \mathrm{ft}$, tailwater Norrell Lock SUSP: Bag sampler and 200-1b weight

METER No: P8308282 DATE RATED: 6-28-88

REMARKS: Transit rate was $5 \mathrm{~cm} / \mathrm{s}$ and the nozzle was $5 / 16$ inch. Anchored at all verticals which were occupied 3 in the following order: 2,1, and $3-10$. The total discharge was $438 \mathrm{~m}^{3} / \mathrm{s}$.

\begin{tabular}{|c|c|c|c|c|c|c|c|c|c|}
\hline \multirow{3}{*}{$\begin{array}{c}\text { Verti- } \\
\text { cal }\end{array}$} & \multirow{3}{*}{$\begin{array}{l}\text { Dist. } \\
\text { from } \\
\text { LEW } \\
(\mathrm{m})\end{array}$} & \multirow{3}{*}{$\begin{array}{l}\text { Depth } \\
\text { (m) }\end{array}$} & \multirow{3}{*}{$\begin{array}{c}\text { Mean } \\
\text { velocity } \\
(\mathrm{m} / \mathrm{s})\end{array}$} & \multirow{3}{*}{$\begin{array}{l}\text { Discharge } \\
\left(\mathrm{m}^{3} / \mathrm{s}\right)\end{array}$} & \multicolumn{2}{|c|}{ Volume } & \multirow{3}{*}{$\begin{array}{l}\text { Temper- } \\
\text { ature } \\
\left.{ }^{\circ} \mathrm{C}\right)\end{array}$} & \multirow{3}{*}{$\mathrm{pH}$} & \multirow{3}{*}{$\begin{array}{l}\text { Conductivity } \\
\text { (micro- } \\
\text { siemens } / \mathrm{cm} \text { ) }\end{array}$} \\
\hline & & & & & $\mathrm{Vi}$ & $V p$ & & & \\
\hline & & & & & $(\mathrm{mL})$ & (L) & & & \\
\hline LEW & 0 & 0.0 & 0.00 & 0 & -- & -- & -- & -- & --- \\
\hline $01 A$ & 17 & 4.3 & 0.85 & 40 & 6850 & 53 & 21.5 & 8.4 & 285 \\
\hline OIB & 17 & 4.3 & 0.85 & -- & 6180 & -- & -- & -- & $-\infty$ \\
\hline OIR & 22 & 4.3 & 0.95 & 35 & - & -- & -- & -- & -- \\
\hline $02 A$ & 34 & 4.2 & 0.92 & 48 & 5200 & 62 & 23.2 & 8.4 & 286 \\
\hline $02 \mathrm{~B}$ & 34 & 4.2 & 0.92 & -- & 6180 & -- & -- & -- & -- \\
\hline $03 \mathrm{~A}$ & 47 & 4.0 & 0.90 & 60 & 5160 & 55 & 22.2 & 8.4 & 287 \\
\hline $03 B$ & 47 & 4.0 & 0.90 & -- & 5680 & -- & -- & -- & --- \\
\hline $04 A$ & 67 & 3.5 & 0.90 & 46 & 4240 & 57 & 21.8 & 8.3 & 283 \\
\hline $04 \mathrm{~B}$ & 67 & 3.5 & 0.90 & -- & 4300 & -- & -- & -- & -- \\
\hline $05 A$ & 76 & 3.4 & 0.83 & 26 & 4200 & 56 & 21.9 & 8.3 & 291 \\
\hline $05 B$ & 76 & 3.4 & 0.83 & -- & 3790 & -- & -- & -- & -- \\
\hline $06 \mathrm{~A}$ & 86 & 3.3 & 0.82 & 40 & 4530 & 47 & 22.2 & 8.3 & 287 \\
\hline 06B & 86 & 3.3 & 0.82 & -- & 3090 & -- & -- & -- & --- \\
\hline $07 A$ & 105 & 3.1 & 0.78 & 37 & 3450 & 42 & 22.3 & 8.2 & 284 \\
\hline $07 \mathrm{~B}$ & 105 & 3.1 & 0.78 & -- & 2820 & -- & -- & -- & -- \\
\hline $08 \mathrm{~A}$ & 117 & 3.1 & 0.76 & 33 & 3620 & 45 & 22.5 & 8.3 & 291 \\
\hline $08 \mathrm{~B}$ & 117 & 3.1 & 0.76 & -- & 3700 & -- & -- & -- & --- \\
\hline $09 A$ & 133 & 3.1 & 0.79 & 35 & 2670 & 42 & 22.6 & 8.3 & 292 \\
\hline 09B & 133 & 3.1 & 0.79 & -- & 2930 & -- & -- & -- & -- \\
\hline $10 A$ & 146 & 3.3 & 0.74 & 38 & 3760 & 47 & 22.2 & 8.3 & 292 \\
\hline $10 \mathrm{~B}$ & 146 & 3.3 & 0.74 & -- & 3660 & -- & -- & -- & -- \\
\hline REW & 164 & 0.0 & 0.00 & 0 & -- & -- & -- & -- & -- \\
\hline
\end{tabular}




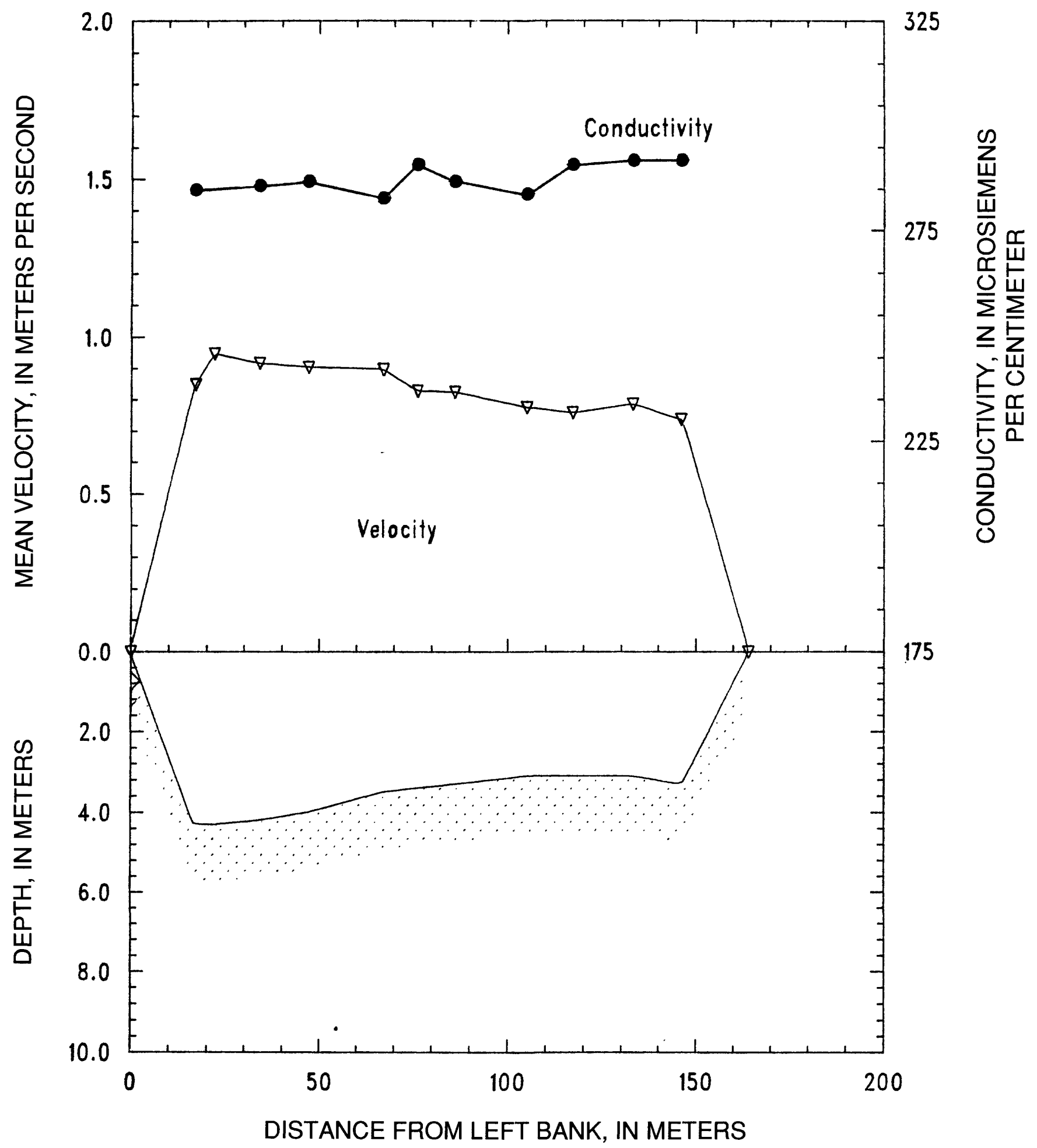

Figure 48. White River at Mile 11.5, Ark. on May 29, 1988. 
STATION: Mississippi River above Árkansas City, Ark.

PARTY: Black, Moody, and Stevens

$5-30-88$

SUSP: Bag sampler and 200-1b weight

METER NO: P8308282 DATE RATED: 6-28-88

REMARKS: Transit rate was $8 \mathrm{~cm} / \mathrm{sec}$ and the nozzle was $3 / 16$ inch. Verticals were occupied in the following order: $1-5,13,6,11,7-10,19,18,17,12,14-16,20-30$. Verticals $1 \& 2$ are average of downcast and upcast. The total discharge was $8160 \mathrm{~m}^{3} / \mathrm{s}$.

\begin{tabular}{|c|c|c|c|c|c|c|c|c|c|}
\hline \multirow{3}{*}{$\begin{array}{c}\text { Verti- } \\
\text { cal }\end{array}$} & \multirow{3}{*}{$\begin{array}{l}\text { Dist. } \\
\text { from } \\
\text { LEW } \\
(m)\end{array}$} & \multirow{3}{*}{$\begin{array}{l}\text { Depth } \\
(\mathrm{m})\end{array}$} & \multirow{3}{*}{$\begin{array}{l}\text { Mean } \\
\text { velocity } \\
(\mathrm{m} / \mathrm{s})\end{array}$} & \multirow{3}{*}{$\begin{array}{l}\text { Discharge } \\
\left(m^{3} / \mathrm{s}\right)\end{array}$} & \multicolumn{2}{|c|}{ Volume } & \multirow{3}{*}{$\begin{array}{c}\text { Temper- } \\
\text { ature } \\
\left({ }^{\circ} \mathrm{C}\right)\end{array}$} & \multirow{3}{*}{$\mathrm{pH}$} & \multirow{3}{*}{$\begin{array}{l}\text { Conductivity } \\
\text { (micro- } \\
\text { siemens } / \mathrm{cm} \text { ) }\end{array}$} \\
\hline & & & & & $\mathrm{Vi}$ & $V p$ & & & \\
\hline & & & & & & $(L)$ & & & \\
\hline LEW & 0 & 0.0 & 0.00 & 0 & -- & -- & -- & -- & --- \\
\hline $01 \mathrm{~A}$ & 30 & 2.5 & 0.16 & 14 & 420 & 3 & 23.3 & 8.0 & 473 \\
\hline $02 \mathrm{~B}$ & 73 & 4.5 & 0.68 & 74 & 1650 & 5 & 23.7 & 8.0 & 471 \\
\hline $03 \mathrm{~A}$ & 78 & 5.1 & 0.59 & 52 & 900 & 8 & 23.7 & 8.0 & 469 \\
\hline $04 \mathrm{~B}$ & 107 & 7.9 & 0.67 & 146 & 2140 & 11 & 23.7 & 8.0 & 472 \\
\hline $05 \mathrm{~A}$ & 133 & 9.4 & 0.56 & 142 & 1720 & 13 & 23.5 & 8.0 & 476 \\
\hline $06 \mathrm{R}$ & 161 & 11.0 & 0.78 & 164 & 3030 & 17 & 24.2 & 8.0 & 464 \\
\hline $06 \mathrm{R}$ & 171 & 12.7 & 0.74 & 165 & -- & -- & -- & -- & --- \\
\hline $07 A$ & 196 & 13.7 & 0.89 & 279 & 4330 & 18 & 24.6 & 8.0 & 475 \\
\hline $08 \mathrm{~B}$ & 217 & 14.2 & 0.82 & 302 & 3960 & 20 & 24.2 & 8.0 & 476 \\
\hline $09 A$ & 248 & 14.6 & 0.98 & 574 & 5140 & 24 & 24.7 & 8.0 & 478 \\
\hline $10 \mathrm{~B}$ & 297 & 15.2 & 1.04 & 444 & 6150 & 26 & 25.1 & 7.9 & 467 \\
\hline $11 \mathrm{~A}$ & 304 & 15.3 & 1.03 & 245 & 5690 & 28 & 24.2 & 8.0 & 463 \\
\hline $12 \mathrm{~B}$ & 328 & 15.6 & 1.09 & 415 & 6730 & 24 & 24.7 & 8.0 & 474 \\
\hline $13 \mathrm{~A}$ & 353 & 15.6 & 1.00 & 477 & 6180 & 27 & 23.8 & 8.0 & 474 \\
\hline $14 \mathrm{~B}$ & 389 & 15.3 & 1.09 & 500 & 4820 & 27 & 23.7 & 8.1 & 466 \\
\hline $15 \mathrm{~A}$ & 413 & 14.4 & 1.06 & 373 & 4780 & 26 & 23.6 & 8.0 & 472 \\
\hline $16 \mathrm{~B}$ & 438 & 13.8 & 1.05 & 363 & 5950 & 26 & 23.5 & 8.0 & 471 \\
\hline $17 \mathrm{~A}$ & 463 & 13.5 & 1.09 & 413 & 5660 & 24 & 24.7 & 8.0 & 471 \\
\hline $18 \mathrm{~B}$ & 494 & 12.7 & 1.12 & 449 & 5840 & 22 & 24.7 & 8.0 & 475 \\
\hline $19 \mathrm{~A}$ & 526 & 11.7 & 1.10 & 401 & 4910 & 22 & 24.5 & 8.0 & 471 \\
\hline $20 \mathrm{~B}$ & 556 & 11.9 & 1.06 & 333 & 4880 & 19 & 23.7 & 8.0 & 470 \\
\hline $21 A$ & 579 & 11.6 & 0.97 & 241 & 4030 & 18 & 23.6 & 8.0 & 473 \\
\hline $22 \mathrm{~B}$ & 599 & 11.3 & 0.96 & 314 & 3970 & 19 & 23.7 & 8.0 & 473 \\
\hline $23 A$ & 637 & 10.7 & 0.88 & 241 & 2930 & 15 & 23.5 & 8.0 & 474 \\
\hline $24 B$ & 650 & 10.6 & 0.78 & 162 & 3230 & 15 & .23 .6 & 8.0 & 473 \\
\hline $25 \mathrm{~A}$ & 676 & 10.3 & 0.72 & 186 & 2370 & 14 & 23.5 & 8.0 & 474 \\
\hline $26 \mathrm{~B}$ & 700 & 10.3 & 0.69 & 219 & 2200 & 12 & 23.5 & 8.0 & 473 \\
\hline $27 \mathrm{~A}$ & 738 & 10.1 & 0.59 & 185 & 1690 & 11 & 23.6 & 8.0 & 473 \\
\hline $28 B$ & 762 & 9.9 & 0.50 & 128 & 1550 & 8 & 23.6 & 8.0 & 472 \\
\hline $29 A$ & 790 & 8.9 & 0.41 & 97 & 590 & 6 & 23.6 & 8.0 & 473 \\
\hline $30 \mathrm{~B}$ & 815 & 6.3 & 0.38 & 58 & 370 & 3 & 23.7 & 8.0 & 472 \\
\hline REW & 838 & 0.0 & 0.00 & 0 & -- & -- & -- & -- & --- \\
\hline
\end{tabular}




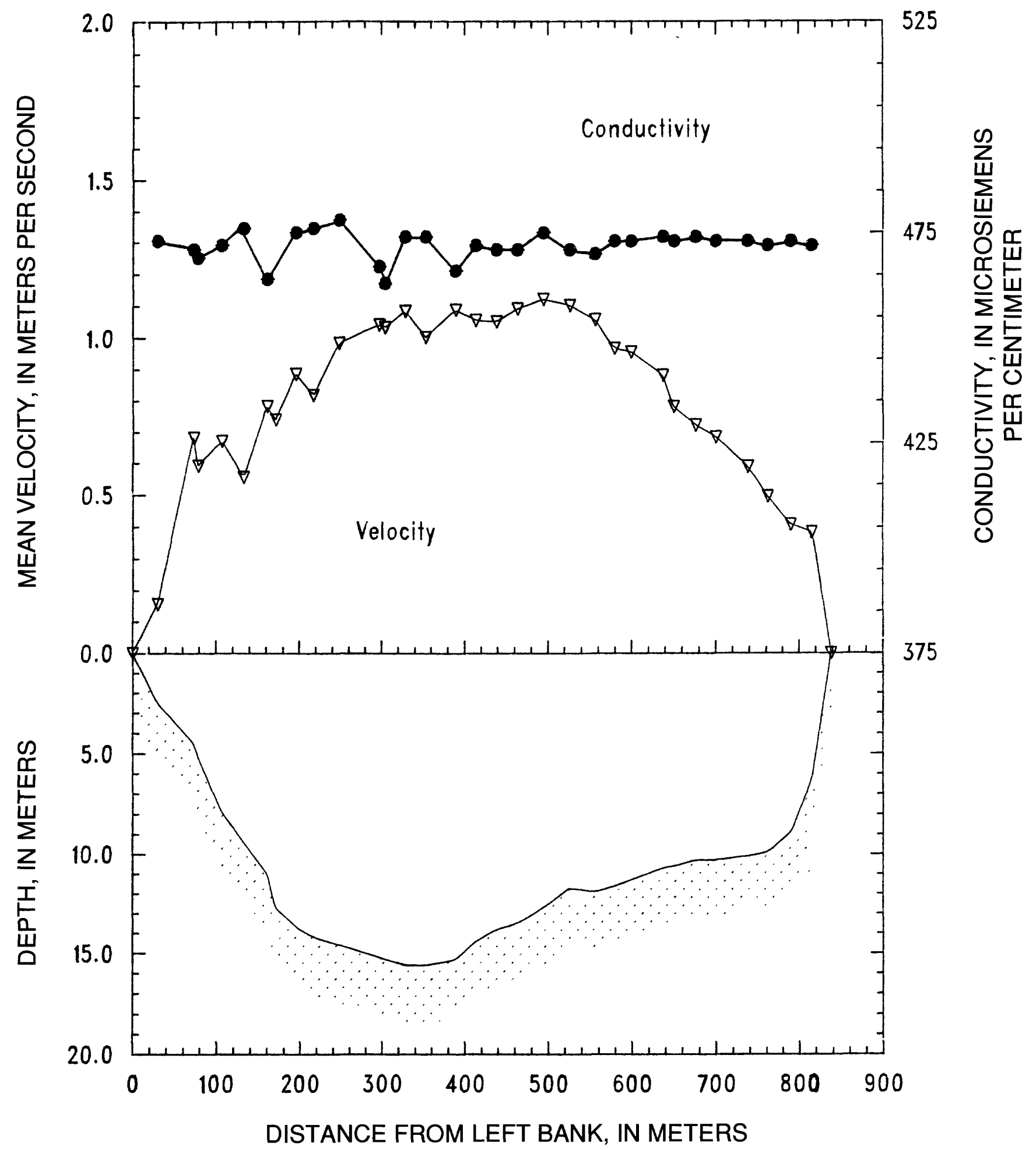

Figure 49. Mississippi River above Arkansas City, Ark. on May 30, 1988. 
STATION: Yazoo River at Mile 10, Miss.

PARTY: Black, Moody, and Stevens

STARTING GAGE HEIGHT: $15.0 \mathrm{ft}$

METER: SOLID CUP

SUSP: Dip sample from bow of small boat

METER NO: W297222 DATE RATED: 4-15-88

REMARKS: Anchored at one location and collected $600 \mathrm{~L}$ by pumping.

Mississippi District measured the discharge from a small boat and it was $80 \mathrm{~m}^{3} / \mathrm{s}$. A dip sample was collected from the bow of the small boat to serve as the integrated sample.

\begin{tabular}{|c|c|c|c|c|c|c|c|c|c|}
\hline \multirow{3}{*}{$\begin{array}{c}\text { Verti- } \\
\text { cal }\end{array}$} & \multirow{3}{*}{$\begin{array}{l}\text { Dist. } \\
\text { from } \\
\text { LEW } \\
(m)\end{array}$} & \multirow{3}{*}{$\begin{array}{l}\text { Depth } \\
\text { (m) }\end{array}$} & \multirow{3}{*}{$\begin{array}{l}\text { Mean } \\
\text { velocity } \\
(\mathrm{m} / \mathrm{s})\end{array}$} & \multirow{3}{*}{$\begin{array}{l}\text { Discharge } \\
\left(\mathrm{m}^{3} / \mathrm{s}\right)\end{array}$} & \multicolumn{2}{|c|}{ Volume } & \multirow{3}{*}{$\begin{array}{l}\text { Temper- } \\
\text { ature } \\
\left({ }^{\circ} \mathrm{C}\right)\end{array}$} & \multirow[t]{3}{*}{$\mathrm{pH}$} & \multirow{3}{*}{$\begin{array}{l}\text { Conductivity } \\
\text { (micro- } \\
\text { siemens/cm) }\end{array}$} \\
\hline & & & & & $\nabla i$ & $V p$ & & & \\
\hline & & & & & $(\mathrm{mL})$ & $(L)$ & & & \\
\hline LEW & 0 & 0.0 & 0.00 & 0 & -- & -- & -- & - & --- \\
\hline $01 \mathrm{~A}$ & 25 & 5.0 & -- & -- & -- & -- & 26.6 & 7.5 & 262 \\
\hline 02B & 50 & 6.5 & -- & -- & -- & -- & 27.0 & 7.6 & 262 \\
\hline REW & 115 & 0.0 & 0.00 & 0 & - & -- & -- & -- & -- \\
\hline
\end{tabular}


STATION: Mississippi River below Vicksburg, Miss.

PARTY: Black, Moody, and Stevens

STARTING GAGE HEIGHT: $8.02 \mathrm{ft}$

$6-02-88$

SUSP: Bag sampler and 200-1b weight

METER NO: P8308282 DATE RATED: 6-28-88

REMARKS: Transit rate, was $8 \mathrm{~cm} / \mathrm{s}$ and the nozzle was $3 / 16$ inch. The total discharge was $7950 \mathrm{~m}^{3} / \mathrm{s}$.

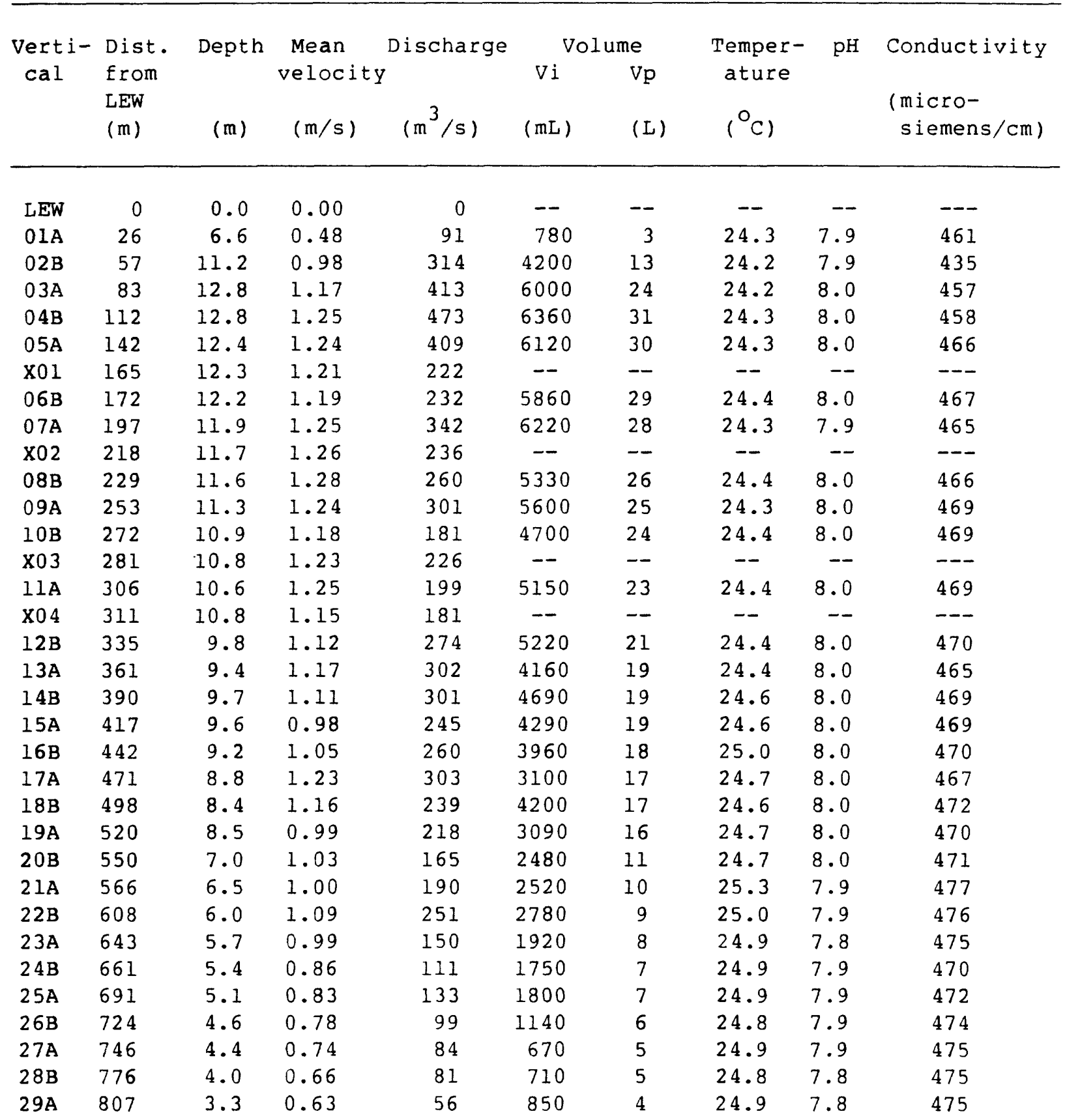


STATION: Mississippi River below Vicksburg, Miss.

$6-02-88$ (continued)

\begin{tabular}{|c|c|c|c|c|c|c|c|c|c|}
\hline \multirow{3}{*}{$\begin{array}{c}\text { Verti- } \\
\text { cal }\end{array}$} & \multirow{3}{*}{$\begin{array}{l}\text { Dist. } \\
\text { Erom } \\
\text { LEW } \\
(m)\end{array}$} & \multirow{3}{*}{$\begin{array}{l}\text { Depth } \\
\text { (m) }\end{array}$} & \multirow{3}{*}{$\begin{array}{l}\text { Mean } \\
\text { velocity } \\
(\mathrm{m} / \mathrm{s})\end{array}$} & \multirow{3}{*}{$\begin{array}{l}\text { Discharge } \\
\left(\mathrm{m}^{3} / \mathrm{s}\right)\end{array}$} & \multicolumn{2}{|c|}{ Volume } & \multirow{3}{*}{$\begin{array}{l}\text { Temper- } \\
\text { ature } \\
\left({ }^{\circ} \mathrm{C}\right)\end{array}$} & \multirow[t]{3}{*}{$\mathrm{pH}$} & \multirow{3}{*}{$\begin{array}{l}\text { Conductivity } \\
\text { (micro- } \\
\text { siemens } / \mathrm{cm} \text { ) }\end{array}$} \\
\hline & & & & & $V i$ & $V p$ & & & \\
\hline & & & & & $(m L)$ & $(L)$ & & & \\
\hline $30 \mathrm{~B}$ & 830 & 3.4 & 0.73 & 65 & 850 & 5 & 24.9 & 7.8 & 461 \\
\hline $31 A$ & 860 & 3.0 & 0.52 & 41 & 460 & 3 & 25.1 & 7.8 & 468 \\
\hline $32 \mathrm{~B}$ & 883 & 2.8 & 0.57 & 42 & 380 & 2 & 24.9 & 7.9 & 470 \\
\hline $33 \mathrm{~A}$ & 913 & 2.6 & 0.52 & 38 & 320 & 3 & 25.1 & 7.9 & 451 \\
\hline $34 \mathrm{~B}$ & 940 & 2.6 & 0.57 & 40 & 330 & 2 & 25.1 & 8.0 & 466 \\
\hline $35 \mathrm{~A}$ & 968 & 2.3 & 0.59 & 38 & 350 & 2 & 25.1 & 7.9 & 470 \\
\hline $36 \mathrm{~B}$ & 996 & 2.3 & 0.36 & 24 & 240 & 2 & 25.1 & 7.9 & 470 \\
\hline $37 \mathrm{~A}$ & 1026 & 2.3 & 0.35 & 22 & 340 & 2 & 25.2 & 8.0 & 475 \\
\hline $38 \mathrm{~B}$ & 1051 & 2.3 & 0.50 & 32 & 250 & 2 & 25.3 & 8.0 & 468 \\
\hline $39 A$ & 1081 & 2.4 & 0.58 & 37 & 320 & 2 & 25.4 & 7.8 & 465 \\
\hline $40 B$ & 1104 & 2.3 & 0.54 & 29 & 260 & 2 & 25.5 & 8.0 & 465 \\
\hline REW & 1129 & 0.0 & 0.00 & 0 & -- & -- & -- & -- & --- \\
\hline
\end{tabular}




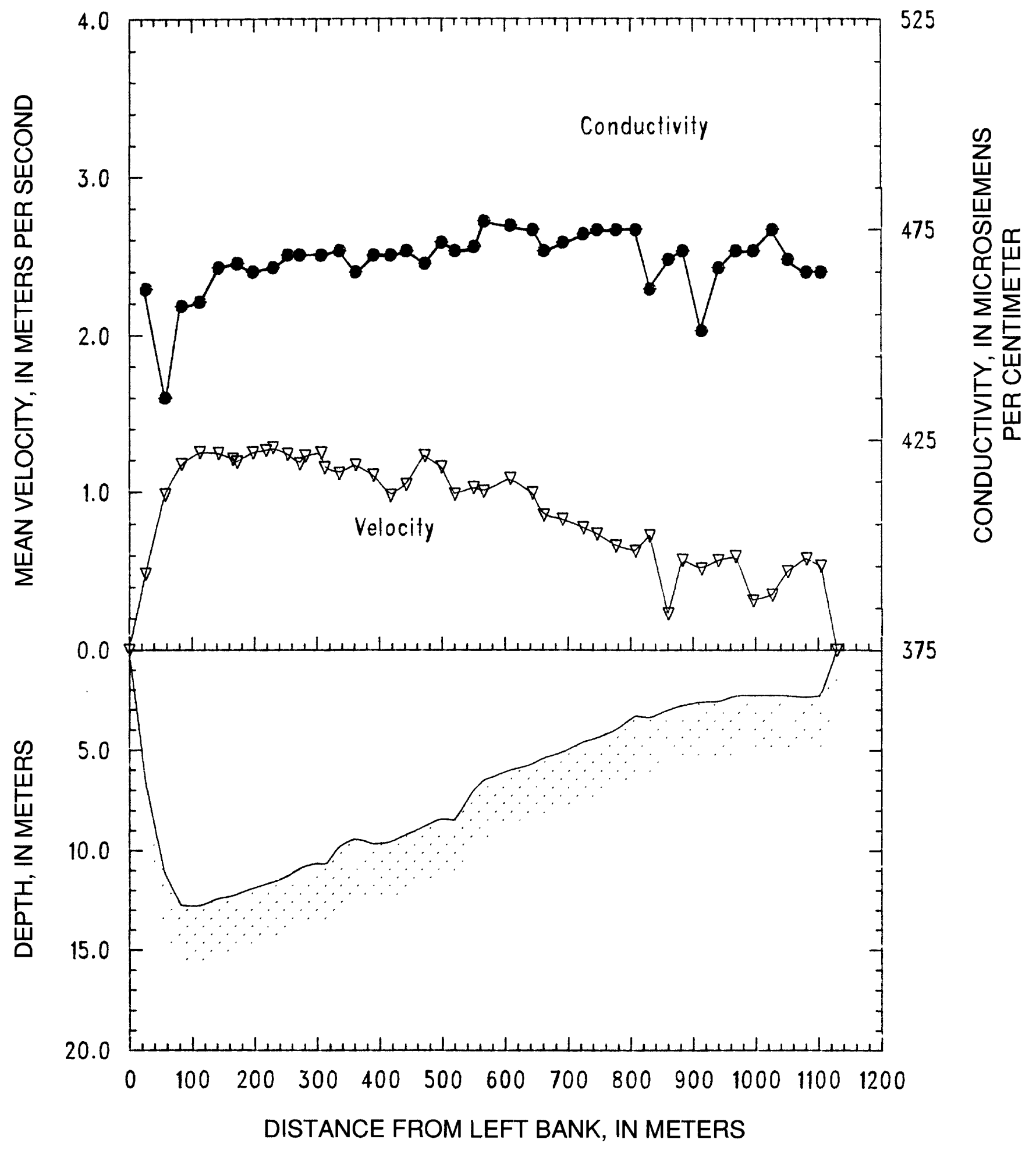

Figure 50. Mississippi River below Vicksburg, Miss. on June 2, 1988. 
STATION: Old River Outflow Cannel near Knox Landing, La. $6-04-88$

PARTY: Black, Moody, and Stevens

STARTING GAGE HEIGHT: --

METER: SOLID CUP

SUSP: Bag sampler and 200-1b weight

METER NO: P8308282 DATE RATED: 6-28-88

REMARKS: Transit rate, was $11 \mathrm{~cm} / \mathrm{sec}$ and the nozzle was $5 / 16$ inch. The total discharge was $2150 \mathrm{~m}^{3} / \mathrm{s}$.

ENDING GAGE HEIGHT: --

\begin{tabular}{|c|c|c|c|c|c|c|c|c|c|}
\hline \multirow{3}{*}{$\begin{array}{c}\text { Verti- } \\
\text { cal }\end{array}$} & \multirow{3}{*}{$\begin{array}{l}\text { Dist. } \\
\text { from } \\
\text { LEW } \\
(\mathrm{m})\end{array}$} & \multirow{3}{*}{$\begin{array}{l}\text { Depth } \\
\text { (m) }\end{array}$} & \multirow{3}{*}{$\begin{array}{l}\text { Mean } \\
\text { velocity } \\
(\mathrm{m} / \mathrm{s})\end{array}$} & \multirow{3}{*}{$\begin{array}{l}\text { Discharge } \\
\left(\mathrm{m}^{3} / \mathrm{s}\right)\end{array}$} & \multicolumn{2}{|c|}{ Volume } & \multirow{3}{*}{$\begin{array}{l}\text { Temper- } \\
\text { ature } \\
\left({ }^{\circ} \mathrm{C}\right)\end{array}$} & \multirow{3}{*}{$\mathrm{pH}$} & \multirow{3}{*}{$\begin{array}{l}\text { Conductivity } \\
\text { (micro- } \\
\text { siemens/cm) }\end{array}$} \\
\hline & & & & & $\mathrm{Vi}$ & $V p$ & & & \\
\hline & & & & & & $(L)$ & & & \\
\hline LEW & 0 & 0.0 & 0.00 & 0 & -- & -- & -- & -- & -- \\
\hline $01 \mathrm{~A}$ & 24 & 5.8 & 1.19 & 124 & 5660 & 15 & 24.5 & 7.9 & 465 \\
\hline 02B & 36 & 6.1 & 1.17 & 107 & 6090 & 23 & 24.3 & 8.0 & 470 \\
\hline $03 A$ & 54 & 6.3 & 1.08 & 98 & 5760 & 33 & 24.5 & 8.0 & 475 \\
\hline $04 \mathrm{~B}$ & 65 & 5.9 & 1.24 & 124 & 6270 & 29 & -- & -- & -- \\
\hline $05 \mathrm{~A}$ & 88 & 5.6 & 1.14 & 109 & 5500 & 28 & -- & -- & -- \\
\hline 06B & 99 & 5.5 & 1.25 & 104 & 5680 & 29 & -- & 8.0 & 472 \\
\hline $07 \mathrm{~A}$ & 118 & 5.3 & 0.96 & 83 & 4880 & 25 & -- & .- & -- \\
\hline $08 \mathrm{~B}$ & 132 & 5.2 & 1.20 & 93 & 4570 & 23 & 24.6 & 8.0 & 476 \\
\hline $09 A$ & 148 & 4.9 & 1.24 & 119 & 5040 & 22 & 24.6 & 8.0 & 476 \\
\hline $10 B$ & 171 & 4.7 & 1.09 & 82 & 4550 & 21 & 24.5 & 8.0 & 476 \\
\hline $11 \mathrm{~A}$ & 180 & 4.8 & 1.00 & 72 & 4370 & 20 & 24.6 & 8.0 & 477 \\
\hline $12 B$ & 201 & 4.4 & 1.01 & 80 & 3720 & 19 & 24.5 & 8.0 & 515 \\
\hline $13 \mathrm{~A}$ & 216 & 4.4 & 1.12 & 76 & 3890 & 18 & 24.6 & 8.0 & 470 \\
\hline $14 B$ & 232 & 4.3 & 0.99 & 70 & 3530 & 17 & 24.4 & 8.0 & 514 \\
\hline $15 \mathrm{~A}$ & 249 & 4.1 & 0.99 & 82 & 2910 & 17 & 24.3 & 8.0 & 467 \\
\hline 168 & 272 & 3.5 & 0.89 & 54 & 2770 & 13 & 24.2 & 8.0 & 467 \\
\hline $17 \mathrm{~A}$ & 284 & 3.4 & 0.85 & 39 & 2430 & 12 & 24.6 & 8.0 & 515 \\
\hline $18 \mathrm{~B}$ & 299 & 3.5 & 0.88 & 47 & 2430 & 12 & 24.3 & 8.0 & 471 \\
\hline $19 \mathrm{~A}$ & 314 & 3.3 & 0.96 & 49 & 2360 & 11 & 24.6 & 8.0 & 471 \\
\hline $20 \mathrm{~B}$ & 330 & 3.3 & 0.72 & 39 & 2050 & 11 & 24.6 & 8.0 & 468 \\
\hline $21 A$ & 347 & 3.1 & 0.82 & 44 & 1960 & 10 & 24.6 & 8.0 & 464 \\
\hline $22 B$ & 365 & 2.8 & 0.90 & 41 & 1650 & 9 & 24.5 & 8.0 & 471 \\
\hline $23 \mathrm{~A}$ & 380 & 2.9 & 0.97 & 43 & 1860 & 9 & -- & - & -- \\
\hline $24 B$ & 395 & 3.1 & 0.97 & 52 & 2200 & 12 & 24.7 & 8.0 & 477 \\
\hline $25 \mathrm{~A}$ & 415 & 3.3 & 0.89 & 53 & 2660 & 12 & 24.6 & 8.0 & 475 \\
\hline $26 B$ & 431 & 3.5 & 0.85 & 45 & 2590 & 13 & 24.6 & 8.0 & 475 \\
\hline $27 \mathrm{~A}$ & 445 & 3.7 & 0.89 & 49 & 2710 & 13 & 24.7 & 8.0 & 474 \\
\hline $28 B$ & 461 & 3.6 & 1.09 & 67 & 2820 & 13 & 24.7 & 8.0 & 476 \\
\hline $29 A$ & 479 & 3.6 & 0.93 & 59 & 2950 & 10 & 24.8 & 8.0 & 475 \\
\hline $30 \mathrm{~B}$ & 496 & 3.5 & 0.76 & 48 & 2190 & 12 & 24.7 & 8.0 & 475 \\
\hline REW & 515 & 0.0 & 0.00 & 0 & -- & -- & -- & -- & --- \\
\hline
\end{tabular}




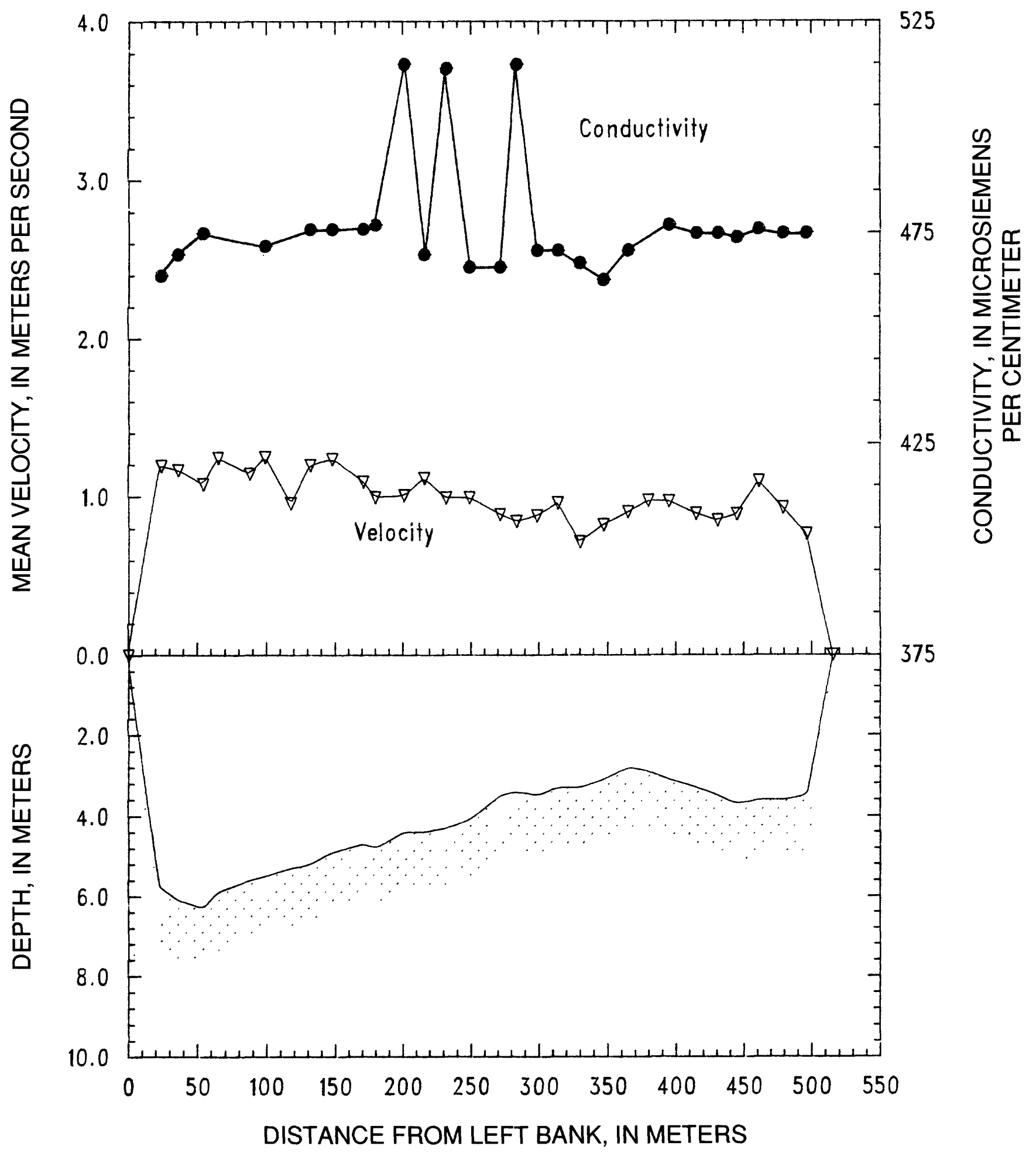

Figure 51. Old River Outflow Channel near Knox Landing on June 4, 1988. 
- STATION: Mississippi River near St. Francisville, LA PARTY: Black, Stevens, and Rees $6-05-88$ STARTING GAGE HEIGHT: -- ENDING GAGE HEIGHT: $11.45 \mathrm{ft}$ at Bayou Sara SUSP: Bag sampler and 200-1b weight

METER NO: P8308282 DATE RATED: 6-28-88

REMARKS: There was heavy rain lasting $1-2$ hours before starting the section. Transit rate was $10 \mathrm{~cm} / \mathrm{sec}$ and the nozzle was $1 / 4$ inch. At verticals 29 and 30 the boat was anchored, the transit rate was $5 \mathrm{~cm} / \mathrm{sec}$, and the bottle was lowered twice. The total discharge was $5700 \mathrm{~m}^{3} / \mathrm{s}$.

\begin{tabular}{|c|c|c|c|c|c|c|c|c|c|}
\hline \multirow{3}{*}{$\begin{array}{c}\text { Verti- } \\
\text { cal }\end{array}$} & \multirow{3}{*}{$\begin{array}{l}\text { Dist. } \\
\text { from } \\
\text { LEW } \\
\text { (m) }\end{array}$} & \multirow{3}{*}{$\begin{array}{l}\text { Depth } \\
\text { (m) }\end{array}$} & \multirow{3}{*}{$\begin{array}{l}\text { Mean } \\
\text { velocity } \\
(\mathrm{m} / \mathrm{s})\end{array}$} & \multirow{3}{*}{$\begin{array}{l}\text { Discharge } \\
\left(\mathrm{m}^{3} / \mathrm{s}\right)\end{array}$} & \multicolumn{2}{|c|}{ Volume } & \multirow{3}{*}{$\begin{array}{l}\text { Temper- } \\
\text { ature } \\
\left({ }^{\circ} \mathrm{C}\right)\end{array}$} & \multirow[t]{3}{*}{$\mathrm{pH}$} & \multirow{3}{*}{$\begin{array}{l}\text { Conductivity } \\
\text { (micro- } \\
\text { siemens/cm) }\end{array}$} \\
\hline & & & & & $\mathrm{Vi}$ & $V p$ & & & \\
\hline & & & & & $(m L)$ & $(L)$ & & & \\
\hline LEW & 0 & 0.0 & 0.00 & 0 & -- & -- & - & -- & --- \\
\hline $30 \mathrm{~B}$ & 90 & 2.3 & 0.24 & 26 & 420 & 9 & 25.2 & 8.0 & 513 \\
\hline $29 A$ & 96 & 2.2 & 0.36 & 17 & 560 & 11 & 25.2 & 8.0 & 513 \\
\hline $28 \mathrm{~B}$ & 133 & 4.9 & 0.45 & 70 & 670 & 10 & 24.8 & 8.0 & 513 \\
\hline $27 A$ & 160 & 5.6 & 0.51 & 96 & 1170 & 10 & 24.6 & 8.0 & 509 \\
\hline $26 \mathrm{~B}$ & 201 & 6.5 & 0.57 & 94 & 1660 & 11 & 24.6 & 8.0 & 514 \\
\hline $25 \mathrm{~A}$ & 211 & 6.5 & 0.65 & 91 & 1640 & 10 & 24.9 & 8.0 & 512 \\
\hline $24 B$ & 244 & 6.5 & 0.75 & 154 & 2150 & 13 & 24.8 & 8.0 & 514 \\
\hline $23 A$ & 274 & 6.8 & 0.71 & 97 & 2490 & 18 & 25.2 & 8.0 & 517 \\
\hline $22 \mathrm{~B}$ & 284 & 7.1 & 0.63 & 90 & 1300 & 16 & 24.6 & 8.1 & 476 \\
\hline $21 \mathrm{~A}$ & 314 & 6.9 & 0.83 & 185 & 2670 & 16 & 24.6 & 8.0 & 518 \\
\hline $20 \mathrm{~B}$ & 349 & 8.2 & 0.94 & 266 & 2750 & 17 & 25.1 & 8.1 & 479 \\
\hline $19 \mathrm{~A}$ & 383 & 7.2 & 0.98 & 222 & 3200 & 17 & 25.3 & 8.0 & 467 \\
\hline $18 \mathrm{~B}$ & 412 & 7.6 & 1.05 & 216 & 3620 & 16 & 24.9 & 8.1 & 469 \\
\hline $17 \mathrm{~A}$ & 437 & 7.9 & 0.89 & 183 & 3640 & 18 & 24.5 & 8.0 & 470 \\
\hline $16 \mathrm{~B}$ & 464 & 8.2 & 0.96 & 268 & 3810 & 16 & 24.8 & 8.0 & 470 \\
\hline $15 \mathrm{~A}$ & 505 & 8.4 & 0.96 & 222 & 3960 & 19 & 24.6 & 8.0 & 462 \\
\hline $14 \mathrm{~B}$ & 519 & 8.7 & 0.78 & 139 & 3480 & 17 & 24.4 & 8.1 & 475 \\
\hline $13 \mathrm{~A}$ & 546 & 8.8 & 0.91 & 224 & 3860 & 19 & 24.3 & 8.0 & 460 \\
\hline $12 \mathrm{~B}$ & 575 & 8.9 & 0.88 & 223 & 3690 & 18 & 24.2 & 8.1 & 467 \\
\hline $11 \mathrm{~A}$ & 603 & 9.2 & 0.93 & 244 & 4250 & 22 & 24.8 & 8.1 & 471 \\
\hline $10 B$ & 632 & 10.2 & 0.90 & 261 & 4320 & 21 & 24.6 & 8.1 & 467 \\
\hline $09 \mathrm{~A}$ & 660 & 10.2 & 0.83 & 228 & 4860 & 21 & 24.5 & 8.1 & 463 \\
\hline $08 B$ & 686 & 10.0 & 0.80 & 252 & 4860 & 18 & 24.8 & 8.1 & 467 \\
\hline $07 \mathrm{~A}$ & 723 & 10.0 & 0.97 & 252 & 5110 & 23 & 24.6 & 8.1 & 468 \\
\hline $06 \mathrm{~B}$ & 738 & 10.7 & 0.95 & 113 & 4860 & 24 & 24.6 & 8.1 & 464 \\
\hline $\mathrm{x} 02$ & 745 & 11.1 & 0.94 & 140 & -- & -- & -- & -- & --- \\
\hline $05 \mathrm{~A}$ & 765 & 11.4 & 0.91 & 207 & 5170 & 24 & 24.9 & 8.1 & 516 \\
\hline $\mathrm{x} 01$ & 785 & 11.6 & 0.91 & 144 & -- & -- & -- & - & --- \\
\hline $04 \mathrm{~B}$ & 792 & 11.8 & 0.88 & 167 & 5660 & 21 & 24.6 & 8.1 & 461 \\
\hline $03 \mathrm{~A}$ & 817 & 11.0 & 0.82 & 235 & 5930 & 21 & 24.7 & 8.1 & 474 \\
\hline 02B & 844 & 12.3 & 0.88 & 314 & 5620 & 14 & 24.4 & 8.1 & 466 \\
\hline $01 \mathrm{~A}$ & 875 & 11.3 & 0.83 & 263 & 4540 & 9 & 24.2 & 8.0 & 516 \\
\hline REW & 900 & 0.0 & 0.00 & 0 & -- & -- & -- & -- & --- \\
\hline
\end{tabular}




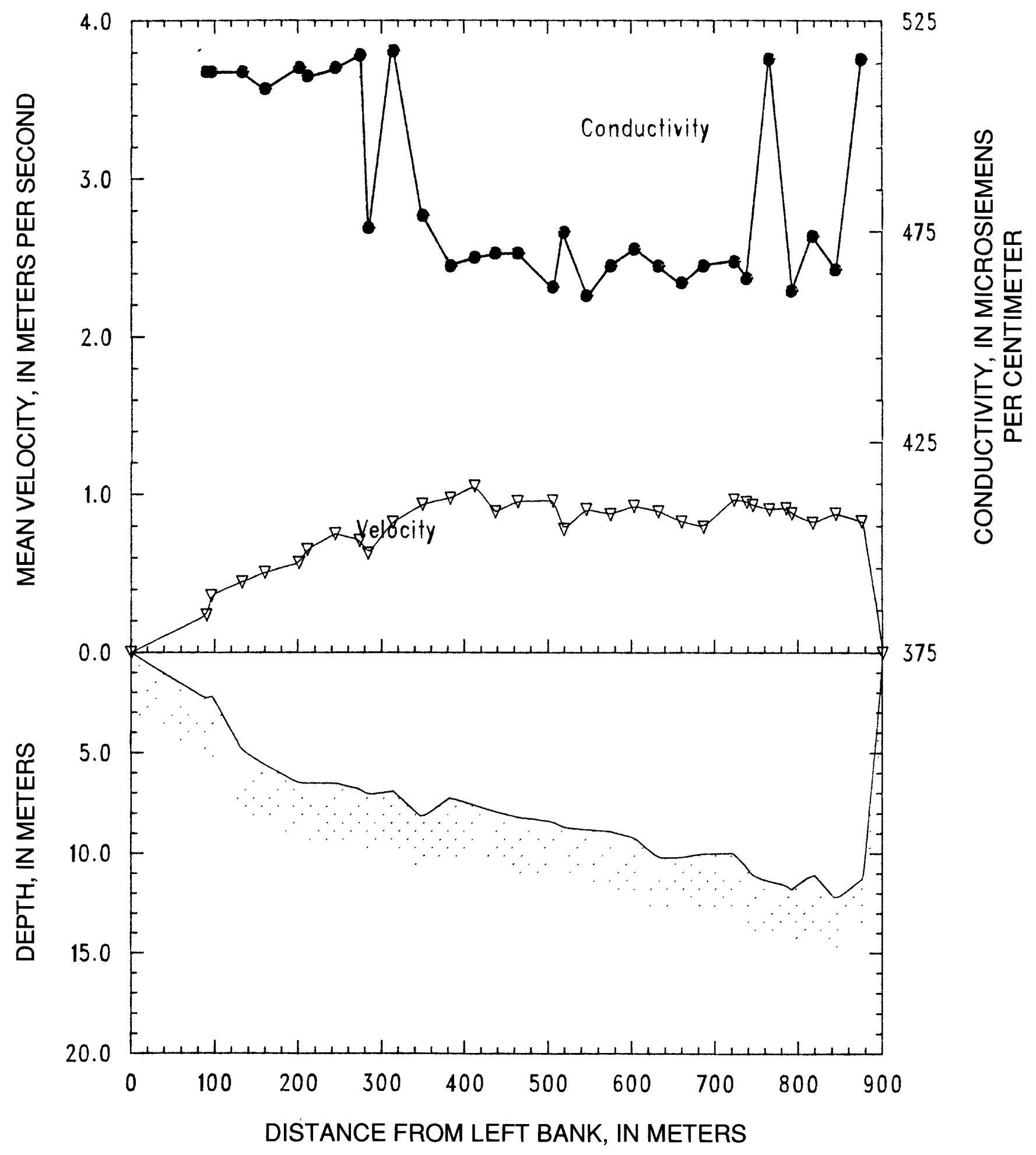

Figure 52. Mississippi River near St. Francisville, La. on June 5, 1988. 
STATION: Mississippi River below Belle Chasse, La.

PARTY: Black, Moody, and Stevens

STARTING GAGE HEIGHT: --

METER:
ENDING GAGE HEIGHT:

$6-07-88$

SUSP: Bag sampler and $200-1 \mathrm{~b}$ weight

METER NO: P8308282 DATE RATED: 6-28-88

REMARKS: Transit rate was $10 \mathrm{~cm} / \mathrm{s}$ and the nozzle was $5 / 16$ inch. Pumped continuously during the station and collected a total of $916 \mathrm{~L}$. The total discharge was $5570 \mathrm{~m}^{3} / \mathrm{s}$.

\begin{tabular}{|c|c|c|c|c|c|c|c|c|c|}
\hline \multirow{2}{*}{$\begin{array}{c}\text { Verti- } \\
\text { cal }\end{array}$} & \multirow{2}{*}{$\begin{array}{l}\text { Dist. } \\
\text { from } \\
\text { LEW } \\
\text { (m) }\end{array}$} & \multirow{2}{*}{$\begin{array}{l}\text { Depth } \\
\text { (m) }\end{array}$} & \multirow{2}{*}{$\begin{array}{l}\text { Mean } \\
\text { velocity } \\
(\mathrm{m} / \mathrm{s})\end{array}$} & \multirow{2}{*}{$\begin{array}{l}\text { Discharge } \\
\left(\mathrm{m}^{3} / \mathrm{s}\right)\end{array}$} & \multicolumn{2}{|c|}{ Volume } & \multirow{2}{*}{$\begin{array}{l}\text { Temper- } \\
\text { ature } \\
\left({ }^{\circ} \mathrm{C}\right)\end{array}$} & \multirow[t]{2}{*}{$\mathrm{pH}$} & \multirow{2}{*}{$\begin{array}{l}\text { Conductivity } \\
\text { (micro- } \\
\text { siemens/cm) }\end{array}$} \\
\hline & & & & & $\begin{array}{l}V i \\
(m L)\end{array}$ & $\begin{array}{l}V p \\
(L)\end{array}$ & & & \\
\hline LEW & 0 & 0.0 & 0.00 & 0 & -- & -- & -- & -- & --- \\
\hline $01 A$ & 29 & 8.0 & 0.22 & 49 & 1140 & -- & - & -- & -- \\
\hline $02 B$ & 57 & 13.2 & 0.33 & 107 & 2570 & -- & -- & -- & -- \\
\hline $03 A$ & 78 & 15.4 & 0.32 & 110 & 2790 & -- & -- & -- & --- \\
\hline $04 \mathrm{~B}$ & 101 & 19.0 & 0.41 & 213 & 5710 & -- & 25.4 & 7.8 & 538 \\
\hline $05 \mathrm{~A}$ & 132 & 19.8 & 0.37 & 189 & 4340 & -- & 25.7 & 7.6 & 534 \\
\hline $06 \mathrm{~B}$ & 153 & 20.3 & 0.42 & 229 & 5950 & -- & 25.4 & 7.5 & 539 \\
\hline $07 \mathrm{~A}$ & 186 & 20.9 & 0.46 & 257 & 6160 & -- & 25.6 & 7.6 & 541 \\
\hline $08 \mathrm{~B}$ & 207 & 21.8 & 0.44 & 228 & 6420 & -- & 25.8 & 7.6 & 537 \\
\hline $09 A$ & 233 & 22.4 & 0.48 & 200 & 6710 & -- & 25.7 & 7.8 & 540 \\
\hline $10 \mathrm{~B}$ & 244 & 22.7 & 0.44 & 242 & 6020 & -- & 25.8 & 7.9 & 542 \\
\hline $11 \mathrm{~A}$ & 281 & 23.2 & 0.40 & 284 & 6210 & -- & 26.0 & 8.1 & 543 \\
\hline $12 \mathrm{~B}$ & 305 & 23.4 & 0.42 & 272 & 5810 & -- & 25.8 & 8.0 & 540 \\
\hline $13 \mathrm{~A}$ & 337 & 23.3 & 0.42 & 255 & 7040 & -- & 25.7 & 8.1 & 539 \\
\hline $14 \mathrm{~B}$ & 357 & 23.4 & 0.40 & 245 & 6620 & -- & 25.4 & 8.1 & 545 \\
\hline $15 \mathrm{~A}$ & 390 & 22.4 & 0.41 & 244 & 6080 & -- & 26.3 & 8.1 & 548 \\
\hline $16 \mathrm{~B}$ & 410 & 22.7 & 0.35 & 199 & 4540 & -- & 25.9 & 8.0 & 548 \\
\hline $17 \mathrm{~A}$ & 440 & 23.3 & 0.38 & 306 & 6260 & -- & 26.1 & 8.0 & 550 \\
\hline $18 \mathrm{~B}$ & 480 & 22.9 & 0.36 & 282 & 4020 & -- & 25.8 & 7.9 & 549 \\
\hline $19 A$ & 509 & 22.6 & 0.34 & 117 & 5300 & -- & 26.5 & 7.9 & 548 \\
\hline $20 \mathrm{~B}$ & 510 & 22.5 & 0.46 & 149 & 5420 & -- & 26.2 & 7.9 & 546 \\
\hline $21 \mathrm{~A}$ & 538 & 22.2 & 0.42 & 273 & 5100 & -- & 26.5 & 8.0 & 547 \\
\hline $22 B$ & 568 & 21.8 & 0.38 & 204 & 4840 & -- & 26.1 & 8.1 & 546 \\
\hline $23 A$ & 587 & 20.8 & 0.22 & 109 & 3310 & -- & 26.4 & 8.0 & 547 \\
\hline $24 \mathrm{~B}$ & 615 & 21.0 & 0.29 & 173 & 3370 & -- & 25.7 & 8.1 & 546 \\
\hline $25 \mathrm{~A}$ & 644 & 20.6 & 0.30 & 158 & 3810 & -- & 25.6 & 8.0 & 545 \\
\hline $26 \mathrm{~B}$ & 666 & 20.3 & 0.31 & 110 & 3660 & -- & 25.8 & 8.1 & 546 \\
\hline $27 \mathrm{~A}$ & 679 & 21.0 & 0.26 & 127 & 3480 & -- & 25.6 & 8.0 & 544 \\
\hline $28 B$ & 713 & 20.0 & 0.28 & 126 & 3650 & -- & 25.8 & 8.0 & 545 \\
\hline $29 A$ & 724 & 14.8 & 0.29 & 80 & 2220 & -- & 26.0 & 8.0 & 547 \\
\hline $30 \mathrm{~B}$ & 751 & 5.2 & 0.23 & 32 & 660 & -- & 26.3 & 8.0 & 537 \\
\hline REW & 778 & 0.0 & 0.00 & 0 & -- & -- & -- & -- & --- \\
\hline
\end{tabular}




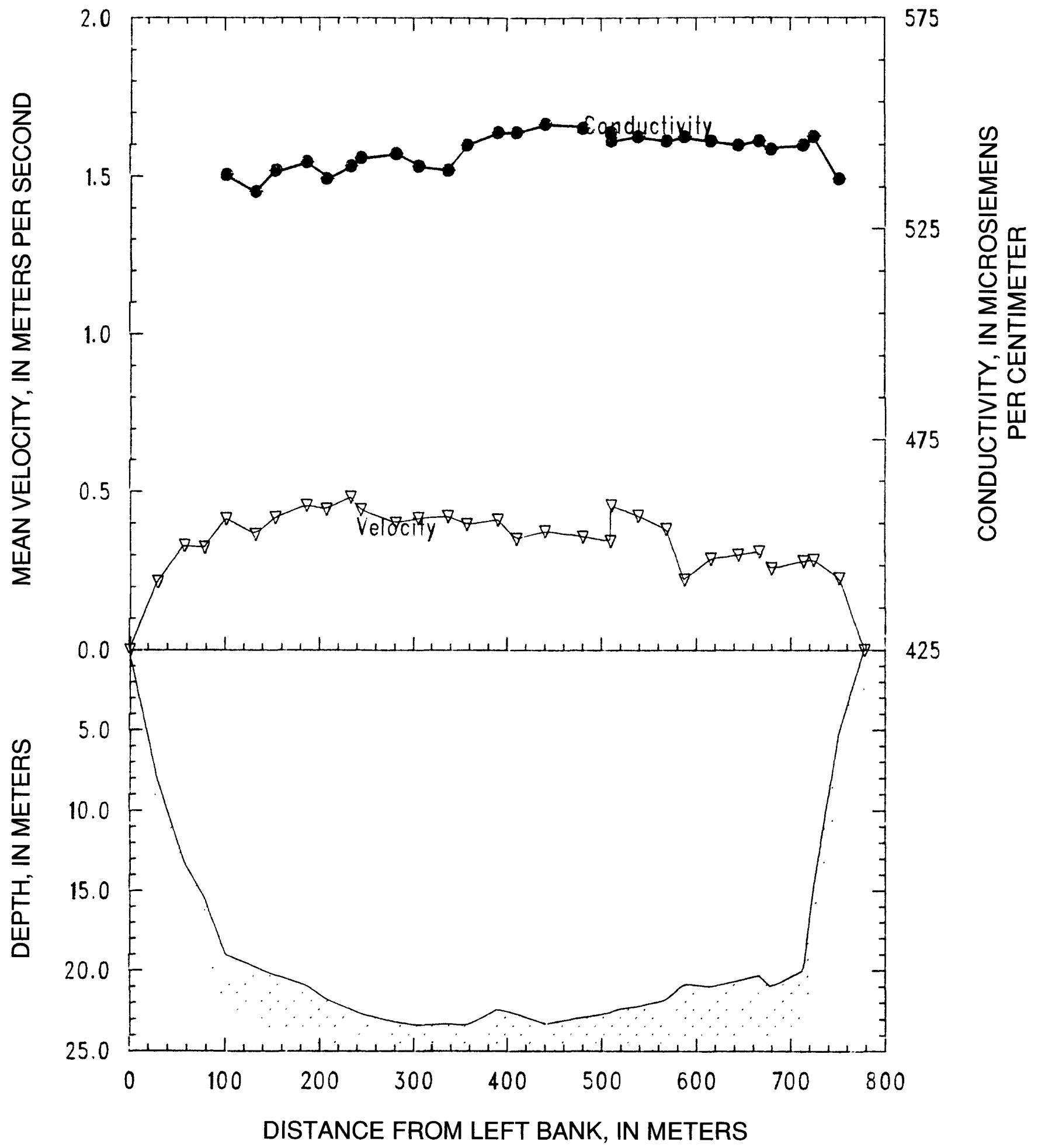

Figure 53. Mississippi River below Belle Chasse, La. on June 7, 1988. 